\title{
Channel development on unreclaimed surface mines in the Beaver Creek watershed, Tucker County, West Virginia
}

Wendy Dawn Igo

West Virginia University

Follow this and additional works at: https://researchrepository.wvu.edu/etd

\section{Recommended Citation}

Igo, Wendy Dawn, "Channel development on unreclaimed surface mines in the Beaver Creek watershed, Tucker County, West Virginia" (2005). Graduate Theses, Dissertations, and Problem Reports. 2182. https://researchrepository.wvu.edu/etd/2182

This Thesis is protected by copyright and/or related rights. It has been brought to you by the The Research Repository @ WVU with permission from the rights-holder(s). You are free to use this Thesis in any way that is permitted by the copyright and related rights legislation that applies to your use. For other uses you must obtain permission from the rights-holder(s) directly, unless additional rights are indicated by a Creative Commons license in the record and/ or on the work itself. This Thesis has been accepted for inclusion in WVU Graduate Theses, Dissertations, and Problem Reports collection by an authorized administrator of The Research Repository @ WVU. For more information, please contact researchrepository@mail.wvu.edu. 


\title{
Channel Development on Unreclaimed Surface
}

Mines in the Beaver Creek Watershed, Tucker

\author{
County, West Virginia
}

Wendy Dawn Igo

Thesis Submitted to

The College of Agriculture, Forestry and Consumer Sciences at West Virginia University in partial fulfillment of the requirements for the degree of

\author{
Master of Science \\ In \\ Agronomy \\ Committee \\ Dr. Jeff Skousen, Chair \\ Dr. John Scencindiver \\ Dr. Steven Kite
}

Department of Plant and Soil Sciences

Keywords: Fluvial geomorphology, Surface mining, Soil properties, Stream restoration, Abandoned mine lands 


\section{ABSTRACT \\ Channel Development on Unreclaimed Surface Mines in the Beaver Creek Watershed, Tucker County, West Virginia}

\section{Wendy Dawn Igo}

Surface mining has impacted channels in the Beaver Creek watershed of Tucker County, West Virginia. Three streams located in areas with similar geology, topography, climate, and mining disturbances were assessed to define similarities in channel development. Soil properties, vegetation coverage, bank stability, and geomorphology were quantified to determine dominant controls on stream form and process.

Streams were unstable and readjusting as evident by inconsistent width-depth ratios, bank instabilities, variable channel gradients, knickpoints, channel incisions, and erosive channels. Dominant controls on channel form were gradient alteration, bank failures, and vegetation coverage. Six classifications of channel types were established.

Without human intervention, instabilities in these streams will continue for many years. If applied adequately, natural channel designs would benefit the restoration of these streams. Reference reaches could be used as the basis of channel re-design. Potential reference reaches were identified, yet most unstable reaches did not satisfy necessary requirements for data extrapolation. 


\section{ACKNOWLEDGEMENTS}

I would like to show my gratitude to Dr. Jeff Skousen for his support and guidance in the preparation of this manuscript. The optimism and encouragement he had for this study were motivating. Dr. Steve Kite proved to be a valuable resource for his knowledge of fluvial geomorphology. Dr. John Sencindiver provided constructive support concerning soil analysis and descriptions. Dr. Ron Fortney deserves a great deal of recognition for the initiation of this study. Christina Venable and Dr. Jim Gorman deserve a special thanks for assistance in data analysis. Finally, I would like to extend my appreciation to Bill and Helen Igo and to Kurt McCoy. My parents provided much needed help with fieldwork and were supportive of my work until the end. Kurt McCoy provided assistance with fieldwork and data analyses and interpretations. His confidence that this study would succeed proved invaluable. 


\section{TABLE OF CONTENTS}

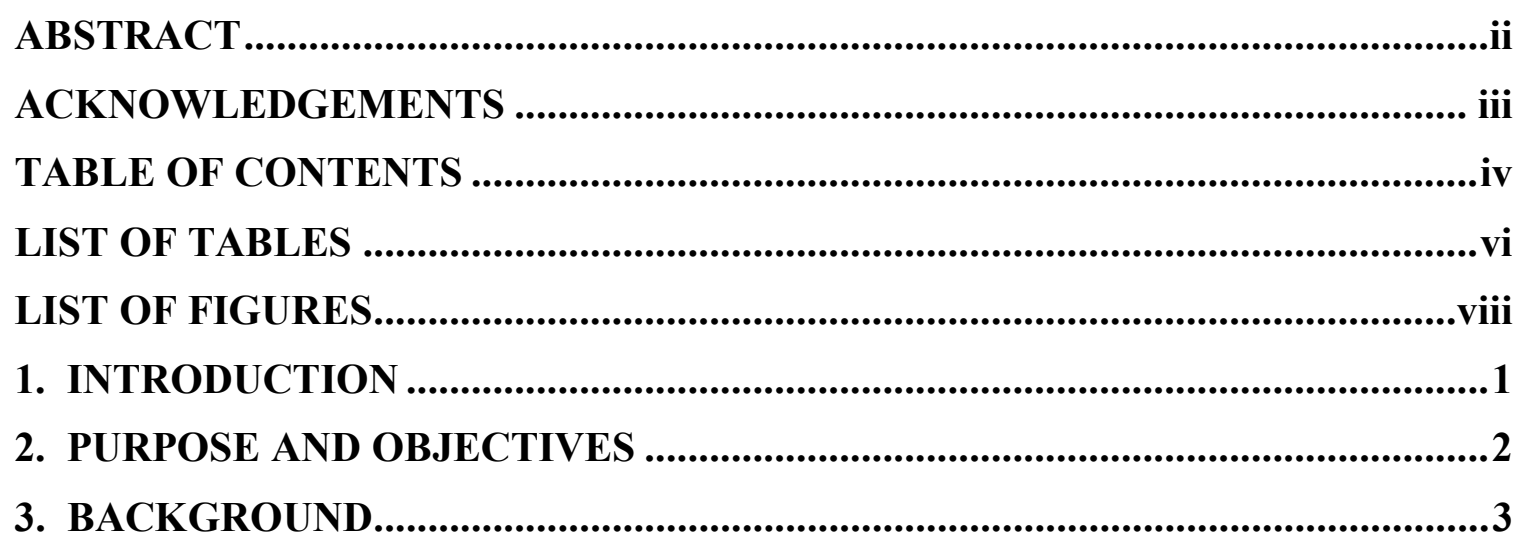

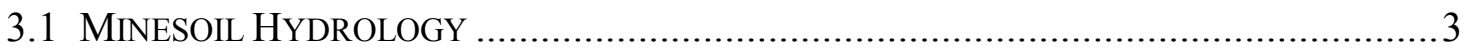

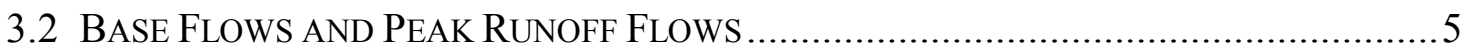

3.3 MoRPhOLOGICAL INFLUENCES ON CHANNEL FORM............................................ 7

3.3.1 Probable Stream Responses to Mining ………........................................

3.3.2 AML Impacts on Streams...................................................................

3.3.3 Impacts of Reclaimed Surface Mines on Streams ..........................................11

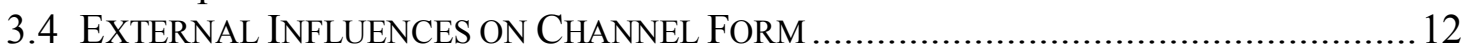

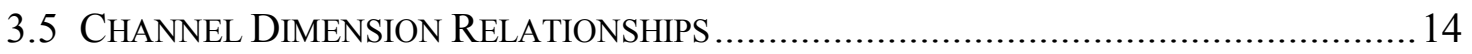

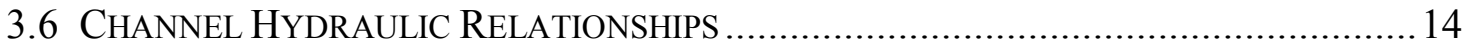

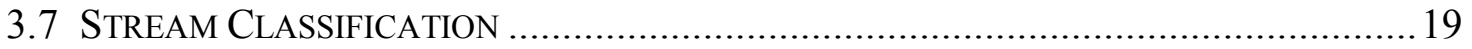

4. MATERIALS AND METHODS...............................................................................23

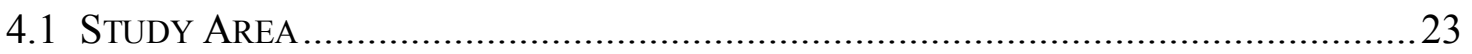

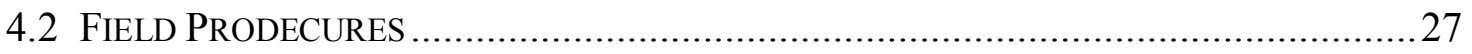

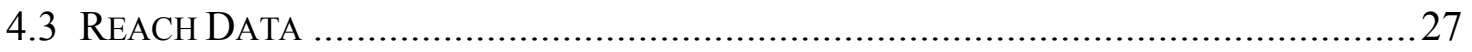

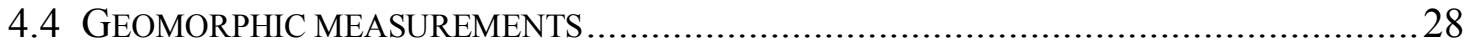

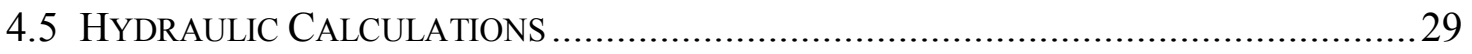

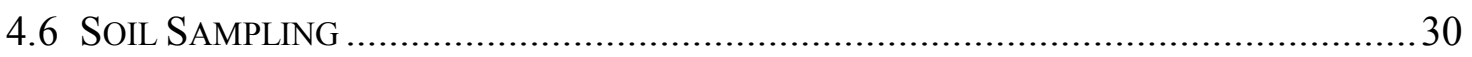

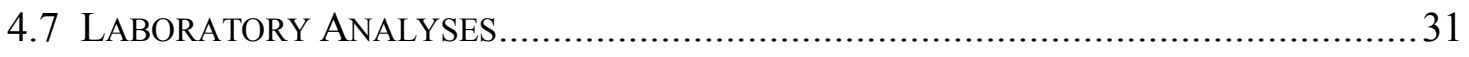

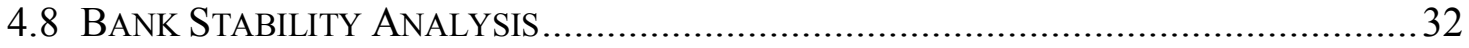

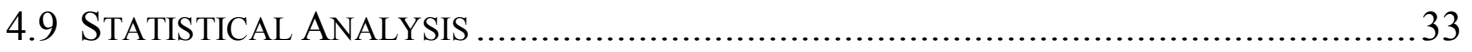

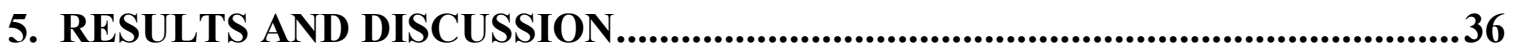

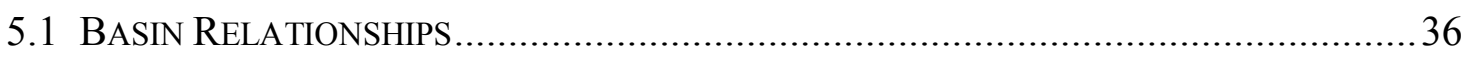

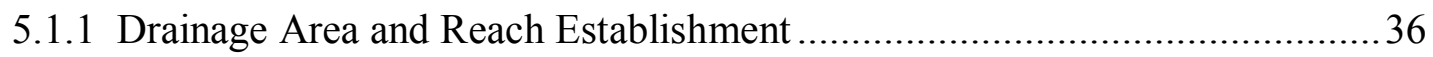

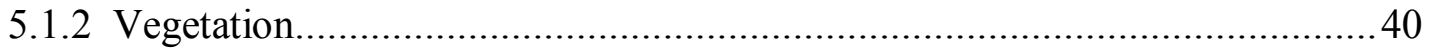

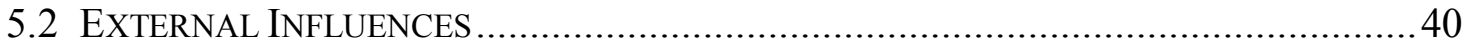

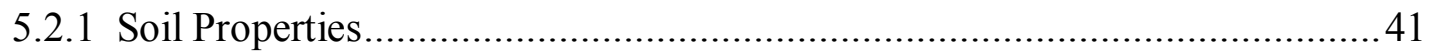

5.2.1.1 Soil Characteristics per Stream ......................................................... 41

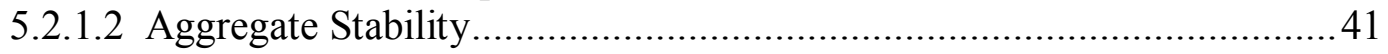

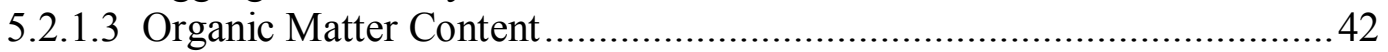

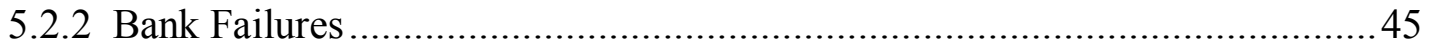




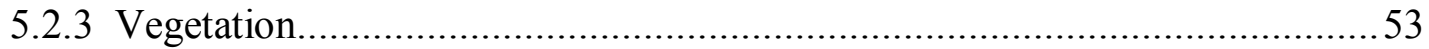

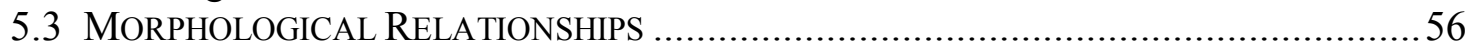

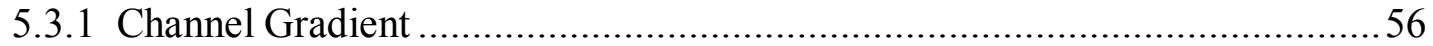

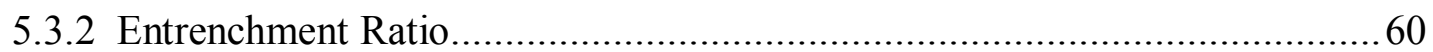

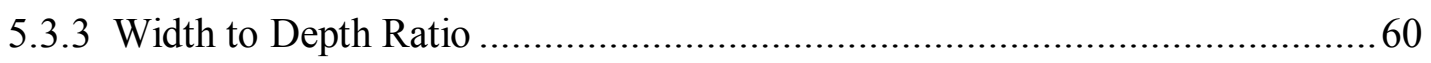

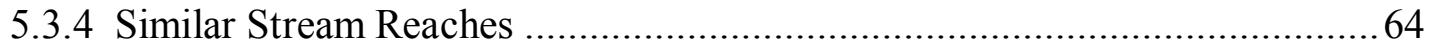

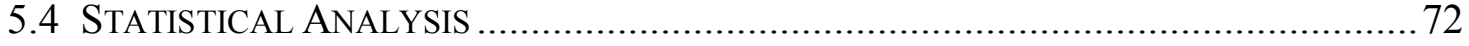

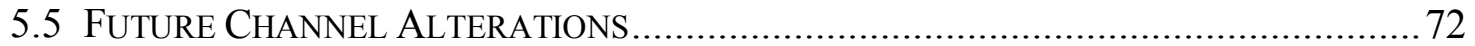

5.5 IMPLEMENTATION OF RESTORATION TECHNIQUES .......................................... 76

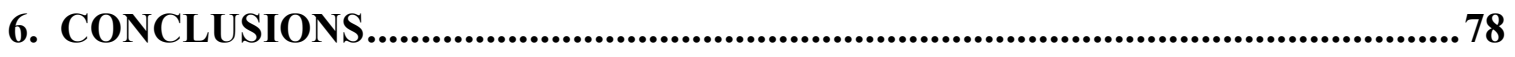

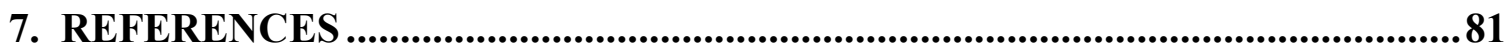

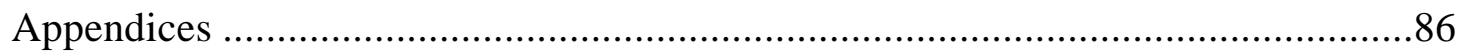




\section{LIST OF TABLES}

Table 1. Descriptions of influential channel dimensions ............................................... 16

Table 2. Bank erodibility hazard guide developed by Rosgen (1996) ............................ 17

Table 3. Description of channel hydraulics and their relation to channel morphology .18

Table 4. Definitive Criteria for the Rosgen Classification System (Rosgen, 1994) ........ 22

Table 5. Core description drilled on the south side of Rt. 93 at Gatzmer (Skousen and

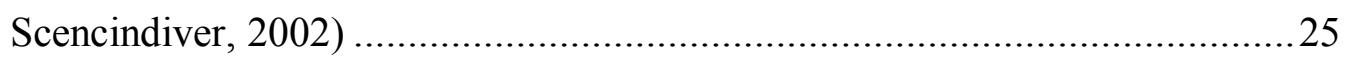

Table 6. Morphological characteristics of Slaty Fork stream reaches ............................ 37

Table 7. Morphologic characteristics of Sphagmun Run stream reaches .........................38

Table 8. Morphologic characteristics of Larch Run stream reaches ................................ 39

Table 9a. Relation of aggregate stability and external variables ...................................43

Table 9b. Relation of aggregate stability and channel morphology...............................43

Table 10. Streambank chanracteristics of Slaty Fork...................................................46

Table 11. Streambank characteristics of Larch Run ....................................................47

Table 12. Streambank characteristic of Sphagnum Run ..............................................48

Table 13. BEHI rating relationships with channel and bed characteristics ....................52

Table 14a. Relation of vegetation coverage and soil properties ....................................54

Table 14b. Relation of vegetation coverage and bank characteristics ...........................54

Table 14c. Relation of vegetation coverage and morphological variables......................54

Table 15a. Relationship of gradient and channel morphology …………………...........57

Table 15b. Relationship of gradient and channel bed characteristics ............................57

Table 15c. Relationship of gradient and streambank characteristics .............................57

Table 16a. Relationship of entrenchment ratio and channel morphology .......................61

Table 16b. Relationship of entrenchment ratio and external variables ............................61

Table 17a. Relationship of entrenchment ratio and channel bed features.......................62

Table 17b. Relationship of entrenchment ratio and soil texture ....................................62

Table 18a. Relation of width-depth ratio and morphological variables ..........................63

Table 18b. Relation of width-depth ratio and streambank characteristics .....................63

Table 18c. Relation of width-depth ratio and external variables ....................................63

Table 18d. Relation of width-depth ratio and soil particle sizes.....................................63

Table 19. Soil properties of similar stream reaches ..................................................68

Table 20. External variables of similar stream reaches ...................................................68 


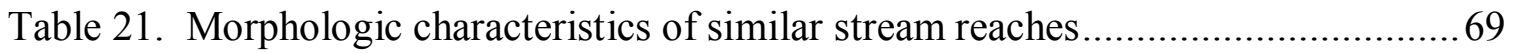

Table 22. Channel characteristics of similar stream reaches ...................................69

Table 23. Streambank characteristics of similar stream reaches .................................69

Table 24. Stream reaches characterized as steep cobble ....................................... 70

Table 25. Stream reaches characterized as transition aggrading .................................. 70

Table 26. Stream reaches characterized as wide aggrading ................................... 70

Table 27. Stream reaches characterized as transition bedrock .................................. 71

Table 28. Stream reaches characterized as bedrock ............................................. 71

Table 29. Stream reaches characterized as wetland .................................................. 71

Table 21. Stream reaches deemed unclassified......................................................... 71 


\section{LIST OF FIGURES}

Figure 1. Study area in the Beaver Creek watershed of Tucker County, West Virginia .24

Figure 2. Erodibility nomograph developed by Wischmeier et al. (1971) .................... 34

Figure 3. Slope-effect chart used to obtain the topographic (LS) factor (US Department of Agriculture, Soil Conservation Service, 1977) ....................................... 35

Figure 4. Comparison of sand content (a), silt content (b), and clay content as a function of aggregate stability 44

Figure 5. Undercut bank located in reach six of Slaty Fork ...................................50

Figure 6. Gulleys on streambanks located in reach two of Slaty Fork.........................50

Figure 7. Slump located in reach one of Larch Run................................................51

Figure 8. Seep with ledge located in reach three of Slaty Fork ...................................51

Figure 9. Comparison of $\mathrm{pH}(\mathrm{a})$, sand content (b), silt content (c), and clay content (d), as a function of percentage vegetation coverage. ........................................55

Figure 10. Comparison of sinuosity (a), D50 particle size (b), and D84 particle size as a function of channel slope.

Figure 11. Comparison of elevation as a function of distance for Slaty Fork (a), Larch Run (b), and Sphagnum Run (c)....

Figure 12. Cluster Analysis of indentified stream reaches 


\section{INTRODUCTION}

The human population has significantly impacted the form and function of river systems throughout the world. With the introduction of industrialization and increasing population, demands on natural resources, including water, land, and energy resources, have increased tremendously. Coal, an energy resource available in high quantities in West Virginia, has been extensively mined for use in heating and electricity generation.

Surface mining is possibly the only land use with a greater capacity to change the hydrologic regime of a stream than urbanization (Federal Interagency Stream Restoration Working Group, 1998). Removing vegetation, disrupting soil and subsurface geologic structure, and altering surface and subsurface hydrologic regimes alter watersheds significantly. Streams are developed, sustained, and adjusted by the water and sediment transported within the channel. The drainage basin is inevitably associated with hillslope processes that contribute water and sediment to the channel network in accord with regional climate, underlying bedrock, and land use by humans (Ritter et al., 2002). Stream channels evolve toward an equilibrium or stable state. Fluvial networks counteract changes in sediment load and discharge by adjusting hydraulic geometry to maintain equilibrium.

Extensive changes to hydrologic conditions occur as a result of surface mining. Geology and stratigraphy of a drainage basin have the greatest effect upon stream drainage patterns and longitudinal profiles (Biedenharn, 1997). Consolidated geologic layers formerly controlling topography and stream channel morphology are no longer

present after surface mining occurs. Consequently, streams will not return to pre-mining conditions, but will rapidly adjust their morphologies while leaning toward a new 
equilibrium compatible with conditions imposed by surface mining and reclamation (Tousinhthiphonexay and Gardner, 1984).

The Surface Mining Control and Reclamation Act (SMCRA) identified abandoned mine land (AML) as land mined, inadequately reclaimed, and abandoned prior to August 3, 1977. State and federal records show that approximately 64,800 hectares in West Virginia $(279,450$ hectares in Appalachia) were disturbed by coal mining before 1977 (Skousen, 1997). Most of these pre-regulation surface mines have no company or individual responsible for reclamation under current laws.

Streams located on AML have been significantly impacted and are highly disturbed. The best approach to restoring these streams is uncertain. The first step in determining the appropriate restoration methods for AML impacted streams is to determine quantifiable and reproducible relationships that can be used in a diagnostic manner. Identification and analysis of channel reaches with similar geomorphic characteristics can help when predicting stream response to such impacts.

\section{PURPOSE AND OBJECTIVES}

Surface mining in the early to middle 1960's degraded streams within the Beaver Creek watershed in Tucker County, West Virginia. Channel morphology has been significantly altered as a result of this mining. Some headwater channels on these mine lands have incised to bedrock, generating steep, highly erosive banks significantly increasing the sediment supply. The streams are primarily composed of aggrading sections with fewer erosional sections. The stream's transport capacity is further impeded by the presence of culverts within the fluvial network. The streams in this study are located in areas with similar geologic, topographic, and climatic history, and had 
experienced similar mining disturbances. Since these controls on channel processes are similar, channel responses since mining disturbance may be determined from channel geometry.

This research assessed three streams geomorphologically to define similarities in channel development on minesoils. Headwater regions of the fluvial systems were assessed to determine dominant controls on stream form and process. Quantification and description of primary channel alterations that have developed since mining can provide data that may help determine the natural responses disturbed streams take to reestablish equilibrium. The objectives of this research were the following:

1. To assess external controls on channel form including soil characteristics, bank failures, and vegetation.

2. To determine channel morphological relationships among stream reaches.

3. To predict future channel alterations that may occur within the streams.

\section{BACKGROUND}

\subsection{MinesOIL HYDROLOGY}

Overburden materials replaced after mining are heterogeneous in nature. Composition of fractured and replaced geologic materials is a direct factor in stream response to mining activity. Minesoil lithology influences hydraulic conductivity in reclaimed mines (Hawkins, 1998). Soils on abandoned sites have been derived from weathering of sandstone, siltstone, and shale overburden. Sandstone-dominated minesoils typically have larger fragments than shale dominated minesoils. Sandstones of the northern Appalachian region tend to be cemented and resistant to breaking and weathering, resulting in large voids and high hydraulic conductivity in minesoils 
(Hawkins, 1998). Hawkins (1995) found the hydraulic conductivity of minesoils in the Appalachian coal fields to be significantly greater than the hydraulic conductivity of adjacent undisturbed rock. Shales generally break into smaller fragments during mining and are more likely to break down to silt- and clay sized particles than sandstones (Messinger, 2003). Caruccio et al. (1984) determined that groundwater flow in a backfill of a surface mine in central West Virginia was highly piped, however, voids were not always well connected. Fine-grained material may fill void spaces between rock fragments and decrease hydraulic conductivity.

The hydrology of minesoils and backfill materials on disturbed areas are poorly understood and one of the least analyzed features of mine drainage prediction. Porosity and hydraulic conductivity of the materials in a backfill are typically greater than those of the consolidated rock overburden that existed before mining (Caruccio and Geidel, 1989). Water follows the course of least resistance when it moves through coarse materials in backfill (Skousen et al., 2000). Even though spoil aquifers may have multiple water tables for short time periods under temporary conditions (Hawkins and Aljoe, 1990), a single continuous watertable with a moderate hydrologic gradient is generally present within the minesoil (Hawkins, 1998). The water table mimics the overlying topography, but is also influenced by permeability variations, local bedrock, and adjacent unmined areas.

Wunsch et al. (1996) found two distinct saturated zones at a large surface mine; one in the minesoil of valley fills and one in the backfill on bedrock layers exposed during mining. Water flowed much faster through saturated zones in valley fills than through the backfill interior. They concluded that water movement inside backfilled spoil piles 
located on a bedrock layer was controlled by buried bedrock topography and interaction of recharge and discharge zones with low-permeability zones.

\subsection{Base Flows And Peak Runoff Flows}

Curtis (1972) found peak runoff rates in unreclaimed surface mined basins to be three to five times greater than unmined forested watersheds. He correlated peak runoff to percent area disturbed during mining. The watersheds at the time of this study were currently being mined or had been mined very recently, thus there was little or no vegetation established in the disturbed areas. Conversely, in successive reports, Curtis $(1977,1979)$ found lower peak runoff from surface mined watersheds. The mined watersheds were reclaimed in 1971 and 1972 and had become vegetated. He attributed lower peak runoff to the presence of vegetation and void areas within the backfill, which provided large amounts of water storage space. Curtis (1979) concluded that well vegetated minesoils can be conducive to good infiltration rates, contributing to reduced peak runoff and higher base flows in streams draining mined watersheds.

Borchers et al. (1991) studied the effects of surface and underground mining on the surface water hydrology of small watersheds in southern West Virginia. Stream discharge and sediment measurements were conducted in two unmined, two actively mined, and one abandoned mine basin. The results did not support the theory that mining causes increased peak flows. Streams in the mined basins had lower high flows, higher low flows, and a greater percent of sand-sized particles in suspended sediment. Borchers et al. (1991) concluded the hydraulic connection of mines to the stress-relief fracture system or to the stream itself determined the effects of mining on base flow. 
Wiley et al. (2001) studied stream geomorphology and storm hydrographs of mined, valley-filled, and unmined basins in southern West Virginia to quantify the impacts of valley fills. Fifty-four sites with similar drainage areas were chosen. Mined sites were defined as watersheds where coal had been mined, but no valley fills had been constructed. Valley fill sites were defined as watersheds that were mined and had valley fills present. During drought conditions in 1999, significantly higher unit discharges were measured from valley fill sites than from adjacent unmined watersheds. Daily stream flows from valley fill watersheds were typically greater than daily streamflows from unmined watersheds during periods of low flow. Wiley et al. (2001) concluded that valley fill sites had a greater percentage of discharge attributed to base flow and a lower percentage of high flow in response to storms than unmined sites.

Messinger (2003) conducted a study that reexamined the results found by Wiley et al. (2001). Greater baseflow of streams affected by mining was interpreted as a reflection of the fact that valley fills are accumulations of large, poorly sorted rocks containing large amounts of void space. Infiltration into the valley fill is stored temporarily, and gradually drains into the stream over a period of days instead of hours, thus decreasing peak flow and increasing base flow. Messinger (2003) concluded that this explanation of flows downstream from valley fills failed to take into consideration surface conditions on mines and water storage in vegetation and soils. Surface conditions at recently reclaimed mines, such as soil compaction and low rates of infiltration into the valley fill, affect runoff patterns (Messinger, 2003).

Messinger (2003) compared storm response of streams in small, unmined watersheds to those in valley-filled watersheds. Mined lands in this study were partially reclaimed, 
receiving a Phase-1 bond release in August of 2000. A Phase-1 bond release is issued when backfilling and grading has been satisfactorily completed and all drainage control features are in place and functioning properly. Mined watersheds showed delayed runoff from slow rains as water infiltrated and flowed through the valley fill, but higher flows 48 or more hours after the rain due to slow release of water retained in void spaces. During high intensity rainfall $(>2.54 \mathrm{~cm} / \mathrm{h})$, peak runoff from the mined basin surpassed runoff from the unmined basin. Messinger (2003) concluded that runoff patterns from reclaimed watersheds were influenced by soil compaction, low maximum rates of infiltration into the valley fill, storage of water in the valley fill, and the absence of interception from trees and leaf litter. His study indicates that large-scale surface mining is likely to increase flooding severity when a period of heavy rainfall follows several days of rainfall.

Wiley et al. (2003) studied the effects of mountaintop removal on peak discharges of streams in small drainage basins. Six basins were selected for the study, three draining valley fill sites. They concluded flood peaks in small headwater basins with valley fills were affected by changes in surface slopes and permeability, deforestation, and construction of sediment ponds downstream from the toe of the fill. The highest frequency of flooding occurred at an actively mined site with an unreclaimed valley fill, which was the only unreclaimed valley fill in the study.

\subsection{MORPHOLOGICAL INFLUENCES ON CHANNEL FORM}

\subsubsection{Probable Stream Responses to Mining}

Stream morphology may be altered drastically by mining activities. Sediment supply can change in volume or particle size, while discharge can change in duration, timing, 
peak flows, or volume as a result of land use activities (Andrews and Nankervis, 1995).

Streams can be completely covered with fill material and relocated (Federal Interagency Stream Restoration Working Group, 1998). Stability of stream channels after surface mining is a function of the overall resistance of soil, vegetation, and boulders to erosion, slope steepness and overall relief, and the ability of the basin to absorb and store sediment (Tousinhthiphonexay and Gardner, 1984).

Surface mining can change the supply of water and sediment and the amount of sediment reaching the channel, resulting in an adjustment of channel geometry and pattern (Chambers and Newell, 2002). Greater rates of aggradation and degradation are likely channel responses to mining. Aggradation occurs when sediment supply is greater than the stream's transport capacity. Channel width increases when sediment fills the streambed. Aggradation decreases pool quality and increases channel width-depth ratio, bank erosion rates, loss of riparian vegetation, and overbank flooding (Rosgen, 1996). Most of the sediment eroded from spoil piles and reclaimed surfaces is not transmitted down the length of the streams, but is trapped in aggrading reaches near stream headwaters (Tousinhthiphonexay, 1982).

Incision occurs when the sediment supply is less than the stream's transport capacity. Incision may cause degradation of channel beds and banks, and removal of gravel or fines. Some channel adjustments associated with degradation include oversteepening of the main stem and tributaries, accelerated bank erosion rates, increased sediment supply and transport, floodplain abandonment resulting in new terraces, changes in vegetation, and steepening of water surface slope (Rosgen, 1996). 
Hudson and Van Haveren (1989) found that when compared to coal mining regions across the United States, central parts of the Appalachian Region experience the most adverse effects of mining on water resources from local topography and its related erosion and sedimentation. This region generally has steep slopes, high precipitation, and frequent flooding. Adverse effects include excessive deposition of sediment in reservoirs and streams, destruction of fish and wildlife habitats, and increased flooding due to decreased efficiency of stream channels and floodplains.

\subsubsection{AML Impacts on Streams}

Numerous minesoils and unreclaimed backfills are present on the landscape in the eastern coal-producing regions. These unreclaimed sites result in water-quality degradation due to acid mine drainage and excessive sediment discharge to streams. At an unreclaimed surface mine in Tennessee, minesoil filled streambeds and caused the streams to seek new channels (Tennessee Department of Environment and Conservation Division of Water Pollution Control, 2003). If the flow capacity of a stream is significantly reduced due to sediment accumulation, the stream will flood more frequently (Ohio Department of Natural Resources, 2003).

Poorly vegetated minesoils, such as those on AML, have high erosion rates resulting in increased sediment in streams, reduced channel capacity, and increased flooding frequency. Curtis (1974) found that exposed surfaces of minesoils experience accelerated weathering and erosion that contribute many times more sediment and runoff to local streams than vegetated, undisturbed watersheds.

In 1959 Collier (1964) compared an unmined channel and a mined channel of the Beaver Creek Basin in Kentucky. Surface mining generated unweathered minesoil banks 
with no vegetation in the mined basin. The rate of weathering, especially chemical weathering, was more rapid in the exposed minesoil banks than in unmined, vegetated soils. Collier (1964) concluded that runoff was actively eroding spoil banks downstream from the mining area and causing excessive gullying and slumping. The gullies were resurveyed in 1962, 1966, and 1974 to determine changes rates of erosion and deposition (McCabe, 1985). Gullies had widened and deepened creating a cutting action that was greater upstream than downstream and reduced channel gradient. Significant erosion had occurred between 1959 and 1966, and downcutting of gullies had continued since 1966, but at a reduced rate.

Curtis (1971) assessed impacts of area- and contour-surface mining on erosion and sedimentation. He found notable changes in suspended load and bedload. The greatest sediment supply occurred during active mining but returned to near pre-mining conditions after the mining subsided, except during severe storms. Curtis found that mass movement on unconsolidated, sparsely vegetated minesoils was an additional source of sediment supply.

Kite et al. (2002) found that mined areas may be southern West Virginia's most potentially lethal flood hazards. Mine wastes spread over the landscape at the angle of repose were the greatest threat because when saturated these materials fail via mass movements. In southern West Virginia, a flood on July 8, 2001 produced hundreds of failures in pre-SMCRA minesoils and refuse piles. Evidence indicated that similar failures occurred frequently in the $20^{\text {th }}$ century. Streams located downstream from minesoils were filled with eroded materials and damaged from past floods. Kite et al. (2002) predicted that an extremely heavy (300-400 $\mathrm{mm}$ in $6 \mathrm{hr})$ rainfall event in 
populated areas with unreclaimed surface mines could kill hundreds and cause greater than $\$ 1$ billion in damage.

\subsubsection{Impacts of Reclaimed Surface Mines on Streams}

Reclaimed mine sites have different properties than unreclaimed sites due to restoration procedures. Some land reclaimed since the SMCRA of 1977 has been overcompacted during reclamation activities (Conrad et al., 2002). Daniels and Zipper (1997) found that minesoils at many mine sites in southwestern Virginia were highly compacted within several feet of the surface due to heavy machinery traffic. Highly compacted sites had bulk density values greater than $1.6 \mathrm{~g} / \mathrm{cm}^{3}$ while undisturbed soils had bulk density values ranging from 1.1 to $1.5 \mathrm{~g} / \mathrm{cm}^{3}$ (Daniels and Zipper, 1997). On a large surface mine in Kentucky, infiltration rates on the bench and into the spoil pile were very low, and in many areas, soil on the reclaimed mine was dry a few inches under the surface shortly after a heavy rain (Wunsch et al., 1996).

Tousinhthiphonexay and Gardner (1984) studied stream response in headwater channels in reclaimed and unmined watersheds. Twenty-nine small $(0.13 \mathrm{~km}$ to $5.72 \mathrm{~km})$ watersheds were assessed. Differences in morphology were observed, including progressively enlarged channels, severe bank erosion, and an increase in occurrence and size of moving sediment with an increase in areal extent of mining. Tousinhthiphonexay and Gardner determined that rapid increases in the size of stream channels and transported sediment was a result of greater erosive forces than resisting forces. This response occurred in first order basins where at least 50 percent of the area was mined. Reclamation techniques such as minesoil compaction and contouring reduced infiltration, surface roughness, and the time of runoff concentration. Tousinhthiphonexay and 
Gardner (1984) concluded that larger basins were more resistant to the effects of mining than smaller basins due to a size buffering effect.

Many coal seams within the Appalachian coalfields crop out on slopes immediately below the ridgelines that form watershed boundaries. Incised first- and second-order streams may occur on adjacent slopes (Smith, 2003). These small fluvial networks contribute channel runoff during heavy precipitation events. Backfilling along the contour to comply with reclamation requirements results in the truncation of headwater streams and significantly influences how the slope directs runoff. This problem results because the contour created for reclamation generally does not correspond to the contour that was present before mining occurred.

Smith (2003) found drainage density (the average length of stream per unit area) decreased by an average of 48 percent between pre-mining and post-mining channels. Bifurcation ratios at each reclaimed area increased after reclamation was completed, showing the disconnectivity of the channels. Field observations revealed significant erosion and stream cutting on these reclaimed areas, and backfill slumps were common near channel truncations.

\subsection{EXTERNAL INFLUENCES ON CHANNEL FORM}

Ratios among sand, silt, and clay are significant determinants of erosion rate. The relative amount of sand and silt are important to erosion since they are the most erodible particles, while rock fragments including cobbles and boulders are not typically erodible in most storm events (Skousen and Sencindiver, 2004). Permeability and infiltration rate affect the soil's erosion potential. Coarse-grained materials have a high infiltration rate, 
which decreases overland flow and erosion. Fine particles, like silts and clays, have a lower infiltration rate and generate more runoff and erosion.

The width-depth ratio of channels is affected by the erosional resistance of channel banks. Streams located on easily eroded, fine sediment are exceptionally sensitive to short-term variations of precipitation and temperature. Bank strength cannot be characterized by a single parameter, but the cohesion of bank materials, which depends on silt and clay content of channel sediments, is very important (Knighton, 1987). Furthermore, the erosional resistance of streambanks may be related to mass wasting processes. Cohesiveness of stream banks and the capacity of streambeds to reduce streamflow by infiltration are lithologic controls of gulley downcutting. Schumm (1960) proposed that channel shape, defined by width-depth ratio, is determined primarily by the properties of sediments in the channel perimeter. Stream banks with high silt and clay percentages generally produce narrow, deep channels, while banks with coarse grained soils produce wide, shallow channels. To demonstrate that the width-depth ratio of arid and semiarid streams is related to the percent silt and clay, Schumm developed the equation:

$$
\mathrm{F}=255 \mathrm{M}^{-1.08}
$$

Where $\mathrm{F}$ is the width-depth ratio and $\mathrm{M}$ is the percent silt and clay in the channel perimeter. Magnitudes of mean annual discharge or the mean annual flood do not appear to affect this relationship (Schumm, 1971).

Bank materials may also reflect the type of sediments transported by the stream. Bull (1997) studied ephemeral streams in western North America and found that most of the sediment is derived from hillslopes and upstream channel banks. Lateral erosion of 
stream banks and upstream movement of headcuts produce local sources of sediment by undercutting; which can initiate mass movement processes. Local bank erosion can be an important source of bedload that can increase aggradation or decrease entrenchment rates. An undercut streambank alters flow widths and depths, which influence unit stream power.

\subsection{Channel Dimension Relationships}

Bankfull discharge represents the flows that achieve the annual maintenance of transporting sediment supplied from upstream sources, forming and removing bars, forming or changing bends, and generally doing work that results in the average channel morphology (Dunne and Leopold, 1978). The stage of bankfull discharge is related to channel dimensions such as meander length, radius of curvature, belt width, meander width ratio, and amplitude (Rosgen, 1996). Correct and dependable interpretations of relationships between geomorphic stream characteristics depend upon correct field identification of bankfull stage and the related discharge. Physical or visual indicators of bankfull stage include the top of the highest depositional features, a floodplain at the elevation of incipient flooding, a break in slope at the banks, a change in particle size distribution, and certain riparian vegetation.

Measurements determined from cross sections include the entrenchment ratio and width-depth ratio. The entrenchment ratio is the vertical containment of the river. Rosgen (1994) quantitatively defined entrenchment ratio as the ratio of stream width prone to flooding in relation to the stream width at bankfull stage. The flood prone width is the width at two times the maximum stream depth at bankfull stage. The entrenchment 
ratio permits identification of flood prone areas that experience relatively frequent flood events.

The width-depth ratio is the ratio of the bankfull surface width to the average depth of the bankfull channel (Rosgen, 1996). This parameter is determined by taking depth measurements at small intervals across the stream and relating the mean depth to channel width. The width-depth ratio is necessary to understand energy distribution within the channel, and the ability of various discharges occurring within the channel to move sediment (Rosgen, 1996). The width-depth ratio indicates channel cross-section shape. Comparisons of width-depth ratio values can describe changes in channel stability after disturbances occur. As width-depth ratio increases, the channel grows wider and shallower and hydraulic stress against the banks increases, accelerating bank erosion (Rosgen, 1996). Mean velocity, stream power, and shear stress decrease as width-depth ratio values increase. A width-depth ratio value of twelve is the threshold for a narrow channel, while a value of 40 indicates a wider channel.

Channel materials affect the cross-sectional form, plan-view, and longitudinal profile of rivers. They also influence the amount of sediment transported and provide resistance to hydraulic stress. Wolman (1954) first developed the "pebble count" technique for field determination of particle size distribution of channel materials. One hundred particles were selected for measurement on the "first blind touch." The intermediate axis of each particle is measured to analyze channel materials.

The longitudinal profile can be used to determine the water-surface slope, channel gradient, and the frequency of bed features. The slope of the water surface is a major determinant of river-channel morphology, and of related sediment and hydraulic 
functions (Rosgen, 1996). Water-surface slope is established along the longitudinal profile of the channel by measuring the difference in water surface elevation per unit stream length.

The frequency of bed features as a function of bankfull width are also determined by the longitudinal profile. Bed features are secondary delineative criteria for describing channel configuration in terms of riffles-pools, rapids, step-pools, cascades and convergence-divergence (Rosgen, 1996). Other useful channel dimension descriptions are listed in Table 1.

Table. 1. Descriptions of influential channel dimensions.

Dimension

Sinuosity

Hydraulic radius

Wetted perimeter

\section{Description}

Ratio of stream length to valley length.

Product of hydraulic mean depth

Perimeter of channel cross section formed by bed and banks

Pool-Riffle ratio Length of pools divided by length of riffles

Rosgen (1996) developed the bank erosion hazard index (BEHI) to quantifiy the potential contribution of bank sediment to the channel. Streambank measurements including bank height, angles, materials, presence of layers, rooting depth, rooting density, and percent bank protection are used to determine BEHI. An example of the Bank Erodibility Hazard Guide is given in Table 2. 
Table 2. Bank erodibility hazard guide developed by Rosgen 1996.

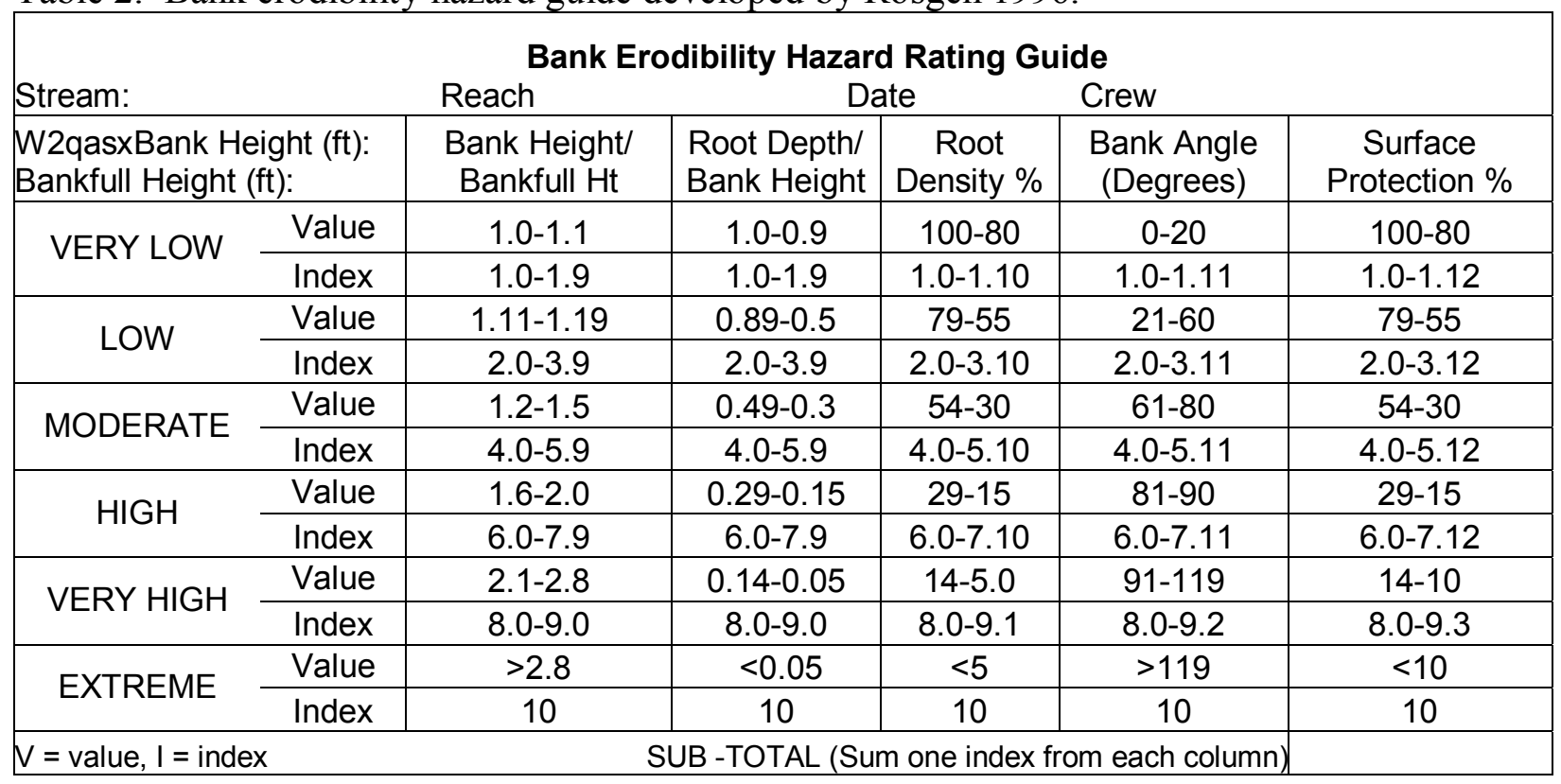

\begin{tabular}{l} 
Bank Material Description: \\
Bank Materials \\
Bedrock (Bedrock banks have very low bank erosion potential) \\
Boulders (Banks composed of boulders have low bank erosion potential) \\
Cobble (Subtract 10 points. If sand/gravel matrix greater than $50 \%$ of bank material, then do not adjust) \\
Gravel (Add $5-10$ points depending on the percentage of bank materials that is composed of sand) \\
Sand (Add 10 points) \\
Silt Clay (+ 0: no adjustment) \\
\hline
\end{tabular}

\begin{tabular}{l} 
Stratification Comments: \\
Stratification \\
Add 5-10 points depending on position of unstable layers in relation to bankfull stage \\
STRATIFICATION ADJUSTMENT \\
\hline
\end{tabular}

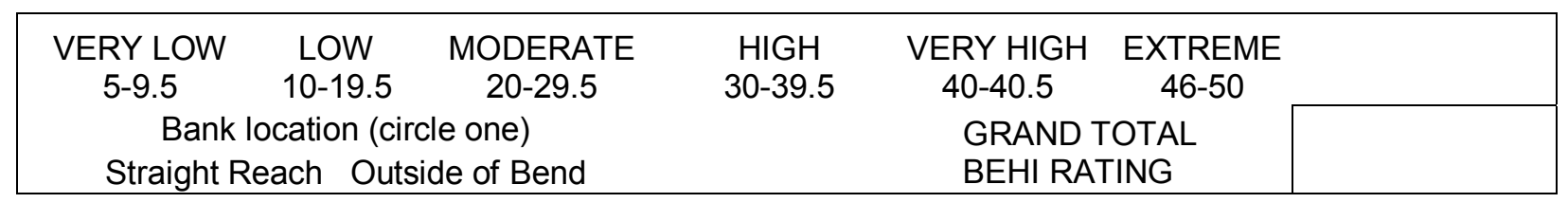




\subsection{Channel Hydraulic Relationships}

Stream flow can vary considerably over short distances and temporally over a range of discharges. When one stream parameter changes, others are also altered. For example, formative channel parameters include channel width, depth, discharge, velocity, gradient, sinuosity, particle roughness, and sediment supply and transport (Leliavsky, 1955). When one of these parameters change, the remaining parameters adjust to attain a new equilibrium.

Hydraulic variables are used to quantify energy expenditures within the channel, bedload transport, and the erosional capability of streams. Some common channel hydraulic variables are listed in Table 3 .

Table 3. Description of channel hydraulics and their relation to channel morphology.

\begin{tabular}{lll}
\hline Parameter & \multicolumn{1}{c}{ Description } & \multicolumn{1}{c}{ Observation } \\
\hline Discharge & $\begin{array}{l}\text { Volume of water passing through } \\
\text { a channel cross section during a } \\
\text { specific time interval. }\end{array}$ & $\begin{array}{l}\text { Moderate discharges } \\
\text { control hydraulic } \\
\text { geometry. }\end{array}$ \\
Critical shear stress & $\begin{array}{l}\text { Downslope component of fluid } \\
\text { weight exerted particles as motion } \\
\text { begins. }\end{array}$ & $\begin{array}{l}\text { Energy available to } \\
\text { transport bedload. }\end{array}$ \\
Shear velocity & $\begin{array}{l}\text { Measure of shear stress that } \\
\text { relates to flow resistance. }\end{array}$ & $\begin{array}{l}\text { Used to calculate } \\
\text { the friction factor. }\end{array}$ \\
Unit stream power & $\begin{array}{l}\text { Analyzes entrainment and } \\
\text { transportation of bedload. }\end{array}$ & $\begin{array}{l}\text { Relates channel gradient } \\
\text { to hydraulic geometry. }\end{array}$ \\
Froude number & $\begin{array}{l}\text { Describes subtypes of turbulent } \\
\text { flow. }\end{array}$ & $\begin{array}{l}\text { F>1 }>\text { supercritical flow } \\
\text { F<1 }\end{array}$ \\
Friction factor & $\begin{array}{l}\text { Reveals characteristics of } \\
\text { the channel bottom }\end{array}$ & $\begin{array}{l}\text { Values varies from } 2 \text { for } \\
\text { rough to 16 for smooth. }\end{array}$
\end{tabular}


Difficulty with equations that relate bed roughness to flow may occur when defining the functional relationship between bed roughness and channel form (Annabelle, 1995). Complexities with these equations arise because the relative contributions of grain size and other resistance components to the total resistance at various flow stages in natural streams are unknown. Long-term monitoring of streams with gauges provides the most accurate hydraulic data.

\subsection{STREAM ClaSSIFICATION}

A universal stream classification system has yet to be developed due to the various channel types and adjustments of individual channels to local factors. An effective stream classification system is needed to identify different stream forms, which could be related to ecosystems and human use of rivers. A classification system is useful for assessment and prediction of channel change. Two classification systems present today are the Montgomery and Buffingham (1997) system and the Rosgen (1994) system.

The Montgomery and Buffingham (1997) classification system is based on streams, commonly found in the Pacific Northwest, that traverse a short distance between headwaters and sea level. This system separates streams according to streams and valleys as follows: steep valleys and hillslopes in the upper watersheds, gentler valleys in the middle watersheds, and low-gradient valleys at the lower end of watersheds. Stream reaches have different morphologies due to interaction between flow hydraulics and sedimentary processes (Montgomery and Buffingham, 1997). Three channel types have been developed: a) colluvial, b) bedrock, and c) free formed and forced alluvial. Freeformed alluvial streams are further divided into five sub-types, including cascade, steppool, plane-bed, pool-riffle, and dune-ripple systems. Morphologies of established reach 
types are related to physical processes that reduce the variety and quantity of possible channel responses to alterations in hydraulic discharge and sediment supply. Reach response is also influenced by external sources, such as channel confinement, vegetation, and large woody debris. Effects of isolated and cumulative disturbances on a specific reach depend on reach position within the watershed and the succession of reach types upstream. Differences in reach morphology and physical processes of a stream produce different responses to similar alterations in discharge or sediment supply.

The Montgomery and Buffingham (1997) classification system has intuitive structure, using existing fluvial terminology and has strong links to process and geologic history. However, this system is not applicable to a wide variety of streambeds and has a weak association to mitigation and assessment.

Rosgen's (1994) stream classification system combines valley morphology with channel relief, pattern, shape and dimension to distinguish stream types. This system is divided into seven major and 42 minor channel types. Seven main stream types are identified by capital letters A to G (Table 4).

Four hierarchical scales of study and delineation are included within the Rosgen system. Level one study produces a general classification based on remote sensing sources, topographic or geologic maps, and a general site visit for field validation. Level two delineation criteria are derived from characteristics of channel cross-section, longitudinal profile, and planform features as measured from field data. Streams are classified based on entrenchment ratio, width-depth ratio, sinuosity, slope, and bed material size. Level three study involves evaluating the current health or state of the stream and predicting future stability based upon current land use practices. The 
necessary data include riparian vegetation, rooting density, depositional patterns, and flow regime analysis. Bank erodibility and channel stability are analyzed to determine the resiliency of the system to land use changes. Level four study provides detailed information on the present state of the stream that can be used for mitigative measures. At this level the following channel characteristics are determined: transport rates, aggradation rates, hydraulic geometry, meander pattern geometry, riparian vegetation inventories and bank erosion rates. While this system has proven utility, it has been criticized as having a confusing structure, not being process based, and being subjective. The nomenclature consists of letters from A through $\mathrm{G}$, revealing no suggestion of the stream's characteristics. Rosgen's (1994) system classifies streams based on geomorphic variables, while many stream processes are not considered. 
Table 4. Definitive criteria for the Rosgen classification system (Rosgen, 1994).

\begin{tabular}{|c|c|c|c|c|c|}
\hline $\begin{array}{l}\text { Stream } \\
\text { Type }\end{array}$ & General Description & $\begin{array}{c}\text { Entrenchment } \\
\text { Ratio }\end{array}$ & $\begin{array}{l}\text { W/D } \\
\text { Ratio }\end{array}$ & Sinuosity & Slope \\
\hline $\mathrm{Aa}+$ & $\begin{array}{l}\text { Very steep, deeply entrenched, debris } \\
\text { transport streams }\end{array}$ & $<1.4$ & $<12$ & 1.0 to 1.1 & $>0.1$ \\
\hline A & $\begin{array}{l}\text { Steep, entrenched, cascading, step/pool } \\
\text { streams. High energy/debris transport } \\
\text { associated with depositional soils. Very } \\
\text { stable if bedrock or boulder dominanted } \\
\text { channel }\end{array}$ & $<1.4$ & $<12$ & 1.0 to 1.2 & $\begin{array}{l}0.04 \\
\text { to } \\
0.1\end{array}$ \\
\hline B & $\begin{array}{l}\text { Moderately entrenched, moderate } \\
\text { gradient, riffle-dominated channel, with } \\
\text { frequently spaced pools. Very stable } \\
\text { plan and profile. Stable banks. }\end{array}$ & 1.4 to 2.2 & $>12$ & $>1.2$ & $\begin{array}{l}0.02 \\
\text { to } \\
0.039\end{array}$ \\
\hline C & $\begin{array}{l}\text { Low gradient, meandering, point bar, } \\
\text { riffle/pool, alluvial channels with broad, } \\
\text { well defined floodplains }\end{array}$ & $>2.2$ & $>12$ & $>1.4$ & $<0.02$ \\
\hline D & $\begin{array}{l}\text { Braided channels with longitudinal and } \\
\text { transverse bars. Very wide channels } \\
\text { with eroding banks. }\end{array}$ & $\mathrm{n} / \mathrm{a}$ & $>40$ & $\mathrm{n} / \mathrm{a}$ & $<0.04$ \\
\hline DA & $\begin{array}{l}\text { Anastomosing (multiple channels) } \\
\text { narrow and deep with expansive well- } \\
\text { vegetated floodplain and associated } \\
\text { wetlands. Very gentle relief with highly } \\
\text { variable sinuosities. Stable stream } \\
\text { banks. }\end{array}$ & $>4.0$ & $<40$ & variable & $<0.005$ \\
\hline$E$ & $\begin{array}{l}\text { Low gradient, meandering, riffle/pools } \\
\text { streams with low width/depth ratios and } \\
\text { little deposition. Very efficient and } \\
\text { stable. High meander width ratio. }\end{array}$ & $>2.2$ & $<12$ & $>1.5$ & $<0.02$ \\
\hline$F$ & $\begin{array}{l}\text { Entrenched meandering riffle/pool } \\
\text { channel on low gradients with high } \\
\text { width/depth ratios. }\end{array}$ & $<1.4$ & $<12$ & $>1.2$ & $<0.02$ \\
\hline G & $\begin{array}{l}\text { Entrenched "fully" step/poool and low } \\
\text { width/depth ratios on moderate } \\
\text { gradients. }\end{array}$ & $<1.4$ & $<12$ & $>1.2$ & $\begin{array}{l}0.02 \\
\text { to } \\
0.039\end{array}$ \\
\hline Continuum & & 0.02 & 2 & 0.2 & .01 \\
\hline
\end{tabular}




\section{MATERIALS AND METHODS}

\subsection{STUdY AREA}

Three streams located in Tucker County West Virginia, along a 1.6-km (1-mile) section of Rt. 93, north of the town of Davis, were the primary focus of the study (Figure 1). All streams were located along the southeast side of Rt. 93, which was mined for the Upper Freeport coal in the middle 1960's. Streams were located in headwater regions and had similar geologic, topographic and climatic histories, and had experienced similar mining disturbances. The three tributaries drained into Beaver Creek. The streams surveyed and sampled in this study were Slaty Fork, Larch Run, and Sphagnum Run. Slaty Fork, was located 5 km (3.2 miles) east of the intersection of Rt. 93 and Rt. 32. Sphagnum Run was approximately 1.6 km (1 mile) north of Slaty Fork. Larch Run was $0.32 \mathrm{~km}$ (0.2 miles) north of Sphagnum Run. All streams were on the southeast side of Rt. 93 and flow in a northwestern direction.

Tucker County has a mean annual air temperature of $8{ }^{\circ} \mathrm{C}$ and a mean annual precipitation of $136 \mathrm{~cm}$ (Losche and Beverage, 1967). Winters are generally long with an average temperature of $-2.22^{\circ} \mathrm{C}\left(28^{\circ} \mathrm{F}\right)$. The growing season is short with the frost-free period averaging 90 days. The short, cooler growing season controls biological systems.

Surface exposures of the Conemaugh and Allegheny groups, and the Kanawha Formation of the Pottsville Group (all of Pennsylvanian Age) occur in the study area. The Conemaugh Group is approximately $183 \mathrm{~m}(600 \mathrm{ft})$ thick. The Upper Freeport coal marks the contact between the Conemaugh Group and the Allegheny Group. The Allegheny group is approximately $46 \mathrm{~m}(150 \mathrm{ft})$ thick, while the underlying Pottsville is 
Figure 1. Study area in the Beaver Creek watershed of Tucker County, West Virginia.

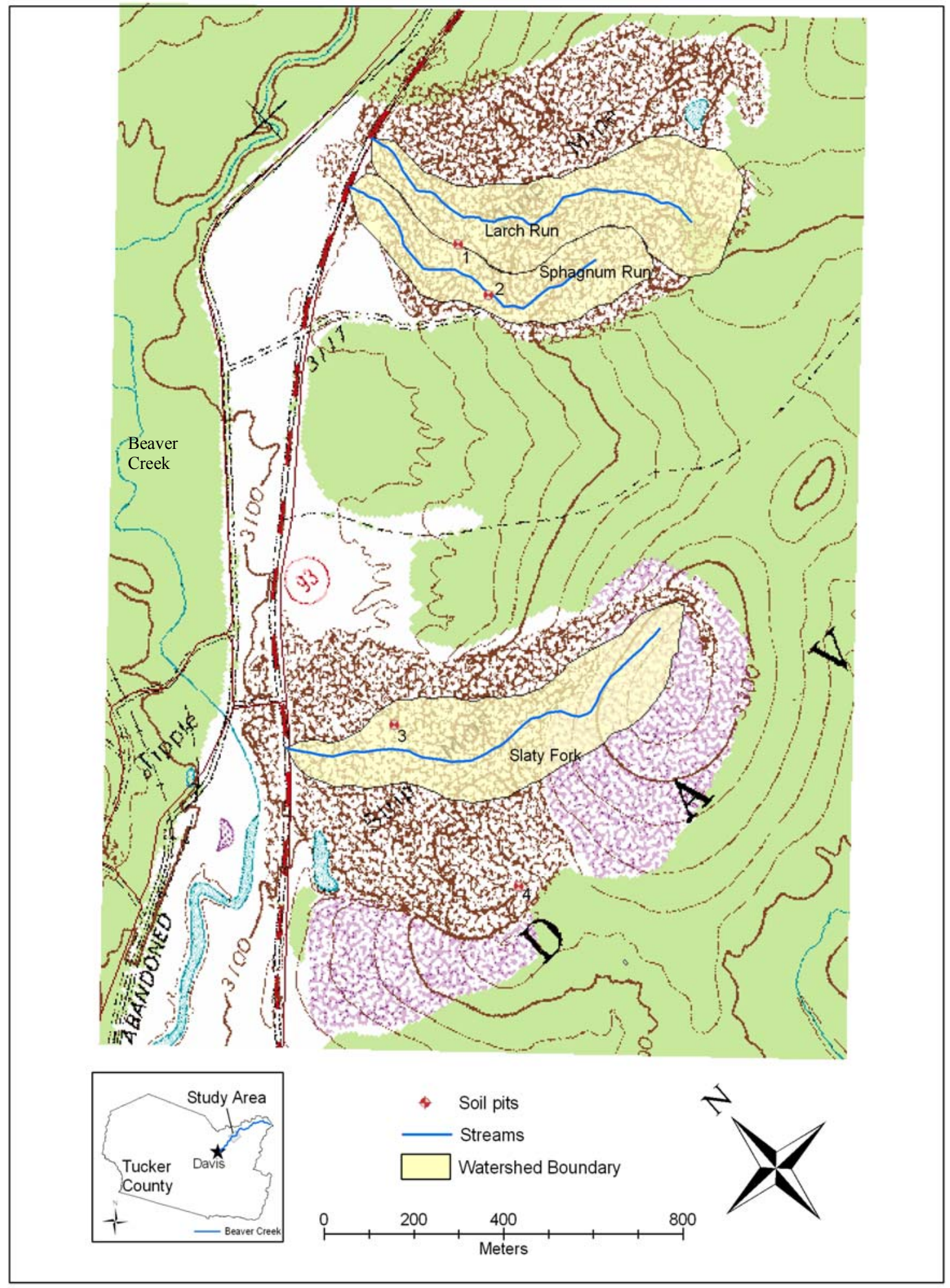


$213 \mathrm{~m}$ (700 ft) thick. Both the Pottsville and Conemaugh groups have sandstones and shales above and below the coal beds. Triad Engineering, Inc. drilled a core on the south side of Rt. 93, approximately $5 \mathrm{~km}$ (3.2 miles) northeast of the study area at Gatzmer, West Virginia (Table 5). The core drillings consisted of $24 \mathrm{~m}$ (78 ft) of interbedded shale and sandstone, $2 \mathrm{~m}(8 \mathrm{ft})$ of the Upper Freeport Coal, and $1+$ meter $(3+$ feet $)$ of limestone before drilling was stopped $31 \mathrm{~m}$ (103 ft) below land surface. The water table was encountered at approximately $18 \mathrm{~m}(60 \mathrm{ft})$ depth.

Table 5. Core description drilled on the south side of Rt. 93 at Gatzmer (Skousen and Sencindiver, 2002).

\begin{tabular}{|c|c|c|c|}
\hline Unit Description & $\begin{array}{c}\text { Thickness } \\
\text { (m) }\end{array}$ & $\begin{array}{c}\text { Cumulative Thickness } \\
\text { (m) }\end{array}$ & $\begin{array}{c}\text { Approximate Elevation } \\
\text { (m) }\end{array}$ \\
\hline Soil, sandy clay & 0.3 & 0.3 & 981.5 \\
\hline Shale, gray, silty, medium-hard & 6.6 & 6.9 & 974.4 \\
\hline Sandstone, gray, fine-grained, hard & 3.0 & 9.9 & 971.4 \\
\hline Shale, gray, silty, medium-hard & 13.7 & 23.6 & 957.7 \\
\hline Coal, Upper Freeport & 2.4 & 26 & 955.2 \\
\hline Shale, gray, silty, medium-hard & 4.1 & 30.2 & 951.0 \\
\hline Limestone, gray, hard & $1.2+$ & 31.4 & 949.8 \\
\hline
\end{tabular}

Before mining, the dominant soils mapped in this area of Tucker County were Brinkerton and Lickdale series (Losche and Beverage, 1967). The Lickdale series (fineloamy, mixed, acid, mesic Humic Endoaquepts) encompasses deep, very poorly drained soils in upland depressions and at streamheads. These soils formed in medium-textured alluvial material originating from shale and sandstone on bordering uplands. The Brinkerton series (fine-silty, mixed, superactive, mesic Typic Fragiaqualfs) is composed of deep, nearly level to moderately sloping, somewhat poorly drained, grayish-brown 
soils that occur extensively on plateaus. Intermittent drainageways are common in these soils.

Mining activities have disrupted the original soil profiles. Surface-mined backfill material primarily consists of Conemaugh overburden disturbed during active surface mining. Deeper earth materials brought to the surface during mining have partially or totally replaced the original profile and this unweathered material rapidly undergoes physical and chemical changes due to its placement near the surface. Minesoils have at least two horizons: a discernible surface horizon and a lower horizon with poor structure and a mixture of rock fragments ranging in size.

Four soil pits, in the current study area, were described to assess post-mining soils (Appendix A). The soils were young in terms of pedogenesis. Three of the soils were classified Inceptisols, while one was an Entisol. All Inceptisols had cambic diagnostic horizons. The formation of cambic horizons in a relatively short time period may be attributed to high weathering rates in minesoils and the planting of pines soon after mining disturbances.

Minesoils in this study had a high rock fragment content that increased from the surface horizons into the subsoils. This finding may be the result of more active chemical and physical weathering at the surface. The soils were acidic with the $\mathrm{pH}$ ranging from 2.3 to 4.9 and generally had low base status. The drainage class was variable, although most were at least moderately-well drained.

The primary plant species identified on these minesoils were red pine (Pinus resinosa Ait.), autumn olive (Elaegnus umbellate Thunb.), blueberry (Vaccinium spp Ait.), and New York fern (Thelypteris noveboracensis Nieuwl.). 


\subsection{Field Prodecures}

The streams were surveyed from Rt. 93 until the channel head was reached. Universe Transverse Mercator (UTM) coordinates were taken using a Garmin 12 channel hand-held Global Positioning Systems (GPS) unit. This type of GPS unit has a precision of $\pm 10 \mathrm{~m}$, assuming adequate satellite coverage. Automatic levels and self-leveling devices were used to measure longitudingal and cross-sectional profiles. Reaches were determined from survey data and evaluations of channel conditions. All reach lengths were at least 20 times channel width. GPS measurements were taken at the beginning of each reach and at the stream's intersection with Rt. 93.

Bankfull stage was identified, flagged, and surveyed where possible. Physical and visual indicators were used to determine bankfull stage; including the top of the highest depositional feature, breaks in active stream bank slopes, and changes in particle size distribution.

\subsection{REACH DATA}

Data were collected from cross sections, which were considered representative of the average character of the reaches' particular morphology. One representative cross section was selected and surveyed for each individual stream reach. Cross sections were located in riffle sections where bankfull indicators were present. Thirty points along the tape were surveyed between right bankfull stage and left bankfull stage. Additional points were collected upslope on banks. Bankfull indicators were noted in cross sections.

Dominant channel materials were determined using the modified Wolman pebble count method described by Wiley (2001), which calculates the D84 percentile. D84 indicates that 84 percent of the particles measured by a pebble count have a mean 
diameter equal to or smaller than $60 \mathrm{~mm}$ (Rosgen, 1996). The D84 percentile has been related to stream roughness, and particles equal to or greater than the 84 percentile are considered large particles (Leopold et al. 1995). Pebble counts were conducted in the following manner.

- The measuring tape was positioned along the thalweg. If the channel was dry the tape was placed along the deepest portion of the channel.

- The pebble count was started at bankfull elevation on the left bank at the upstream boundary of the stream reach. The count advanced downstream toward the right bank at a 45 degree angle (less for short reaches) until bankfull stage was reached on the right bank and was continued downstream in a zig-zag pattern.

- To decrease sampling bias, the bed material was not observed when the sample was picked up.

- The intermediate axis of each clast was measured in $\mathrm{mm}$ or the particle size of smaller materials was estimated by the feel method.

- The process was continued downstream until 100 clasts were collected.

\subsection{GEOMORPHIC MEASUREMENTS}

The following channel dimensions were determined using measurements or calculations from the cross sections:

- Width of the channel at bankfull stage

- Maximum depth of flow at bankfull stage

- Bank height (measured from the channel bed to the top of the lowest bank)

- Width of the flood-prone area (obtained by measuring the flooded width at a stage twice the maximum depth of flow at bankfull stage) 
- Cross-sectional area of bankfull stage

- Sinuosity (determined using a compass and a tape measure). A compass bearing for the valley axis was obtained. Stream length was measured along the thalweg for each reach. Valley length was measured for each reach using the compass bearing for the valley axis.

Additional measured channel dimensions include mean depth, wetted perimeter, hydraulic radius, width depth ratio, entrenchment ratio, and pool to riffle ratio. Channel dimension equations are shown in Appendix B. BEHI was estimated for each reach using methods developed by Rosgen (1996).

\subsection{Hydraulic Calculations}

Bankfull discharge is one of the most critical parameters used to predict the morphological characteristics of streams. The streams in this study were non-gauged, thus there was no hydraulic analysis and flow-frequency analysis due to a lack of long term monitoring information. Since this project was not designed to model flow, discharge calculations were not derived from cross sections. Discharges were estimated using a regionalized equation developed for rural, unregulated West Virginia streams (Wiley et al., 2002). Discharge equations were developed using 11 basin characteristics for 154 rural, nonregulated West Virginia streamflow gaging stations with a minimum of 10 years record. Twelve equations were developed for each of the three regions of West Virginia: East, North, and South. The minimum drainage area used for their study was

$0.35 \mathrm{~km}^{2}, 1.5$ to 4 times the drainage area of streams in this study. Nevertheless, regional equations defined in their study were used to determine discharge in absence of adequate data for modeling. Regional equations were determined by generalized least squares 
regression, and the most significant independent variable was $\log _{10}$ transformed drainage area.

The 1.5- and 3-year discharges for the streams in this study were calculated using equations from the East Region as defined by Wiley et al. (2002). The average prediction error for the 1.5-year discharge is 43 percent, while the average prediction error for the 3 year discharge is 36.8 percent. The 1.5- and 3-year regression equations for the East Region are:

$$
\begin{aligned}
& Q(1.5)=49.9 \mathrm{~A}^{0.838} \\
& Q(3)=80.2 \mathrm{~A}^{0.843}
\end{aligned}
$$

where,

$\mathrm{Q}(1.5)$ is the 1.5 year discharge in cubic feet per second $\mathrm{Q}(3)$ is the 3 year discharge in cubic feet per second, and $\mathrm{A}$ is the drainage area in square miles.

Digitizing watershed boundaries and querying the resulting polygon in ArcMap was used to determine the drainage area for each of the streams in this study. Watershed boundaries were defined by topographic divides noted on the Davis 7.5 minute quadrangle.

The 1.5-and 3-year discharges determined with regional equations were used to calculate stream power. Hydraulic equations are shown in Appendix B.

\subsection{SoIL SAMPLING}

In the summer of 2004, at least two soil samples were taken per reach at the cross sections. Samples were taken from the right and left intact bank between bankfull stage and the channel bottom. Samples were extracted perpendicular to the bank slope to a depth of $10 \mathrm{~cm}$. Soil structure and percentage of rock fragments were determined in the 
field. All soil samples were taken to West Virginia University where physical and chemical analyses were completed in soil laboratories of the Division of Plant and Soil Sciences.

\subsection{LABORATORY ANALYSES}

Soil texture was determined using the pipette method (Soil Survey Staff, 1996). Soils were treated with $10 \mathrm{ml}$ of hydrogen peroxide at $90^{\circ} \mathrm{C}$ for at least one week. Due to the presence of coal particulates within the sample, frothing could not be used to determine if all organic matter was removed. Sands were fractionated by shaking through a nest of sieves for 3 minutes at 50 strokes per minute. The five sand classes were: very coarse $(2.00-1.00 \mathrm{~mm})$, coarse $(1.00-0.5 \mathrm{~mm})$, fine $(0.25-0.10 \mathrm{~mm})$, and very fine $(0.10-0.05 \mathrm{~mm})$.

Aggregate stability was determined using the wet sieve method (Kemper and Rosenau, 1986). Soil samples were sieved, isolating particle size diameters between 4.0 $\mathrm{mm}$ to $2 \mathrm{~mm}$. Samples were placed on a sieve combination: a $2 \mathrm{~mm}$ sieve above a 0.5 $\mathrm{mm}$ sieve, and wet sieved for 3 minutes. Samples were dried at $105^{\circ} \mathrm{C}$, weighed, and the remaining soil particles were removed. Samples were then dried at $105^{\circ} \mathrm{C}$, and weighed again to consider rock fragments.

Organic matter content was determined using the loss of weight on ignition (Storer, 1984). Soils were weighed into crucibles, dried in an oven at $105^{\circ} \mathrm{C}$ overnight, and weighed again. Soils were then placed into a muffle furnace at $400^{\circ} \mathrm{C}$ overnight, cooled, and weighed again. Soil reaction $(\mathrm{pH})$ was determined using a 1:1 water to soil suspension (Method 8C1, Soil Survey Staff, 1996). Carbon to nitrogen ratio was determined using the LECO 2000 (LECO, 1216 Manchester, NY, NY). 
The soil erodibility factor, the $\mathrm{K}$ factor of the Universal Soil Loss equation, was determined for each reach using values from the nomograph developed by Wischmeier et al. (1971) (Figure 2).

The Length-Slope (LS) factor was determined for both the right and left banks at the cross sections. The LS factor shows the influence of slope length and slope steepness on erosion. The horizontal distance was measured from the cross sections. Percent slope was determined using a clinometer in the field. Percent slope and slope length were used to determine the LS factor from the slope-effect nomograph developed by the US Department of Agriculture, Soil Conservation Service (1977) (Figure 3).

\subsection{BANK STABILITY ANALYSIS}

A BEHI rating was determined for each reach using methods developed by Rosgen (1994). Bank height, bank materials, presence of layers, rooting depth, rooting density, and percent bank protection were determined by visual analysis. Bank angle was determined using a clinometer in the field.

Percentage vegetation coverage was estimated for each reach through visual observation. Since vegetation coverage was variable throughout the reaches, percent vegetation values were averaged and normalized. Percent vegetation was estimated for both the right and left bank, while the length of the coverage class was determined using a tape measure placed along the channel. For example, a bank may have had $45 \%$ vegetation coverage for 7 meters and then $15 \%$ vegetation coverage for the next 9 meters. Both the length of coverage and the percentages were taken into consideration.

Type and number of bank failures were determined for each stream through field observations and stream sketches. 


\subsection{Statistical Analysis}

To detect similarities among the stream reaches, a discriminant analysis was run on geomorphic and soils variables to determine which variables produced differences among populations. Variables were discarded as they were deemed no additional help in

discriminating among populations. Variables retained from the analysis include: sand, total silt, fine silt, clay, organic matter content, sinuosity, discharge, and pool to 
Figure 2. Erodibility Nomograph Developed by Wishmeier et al. (1971)

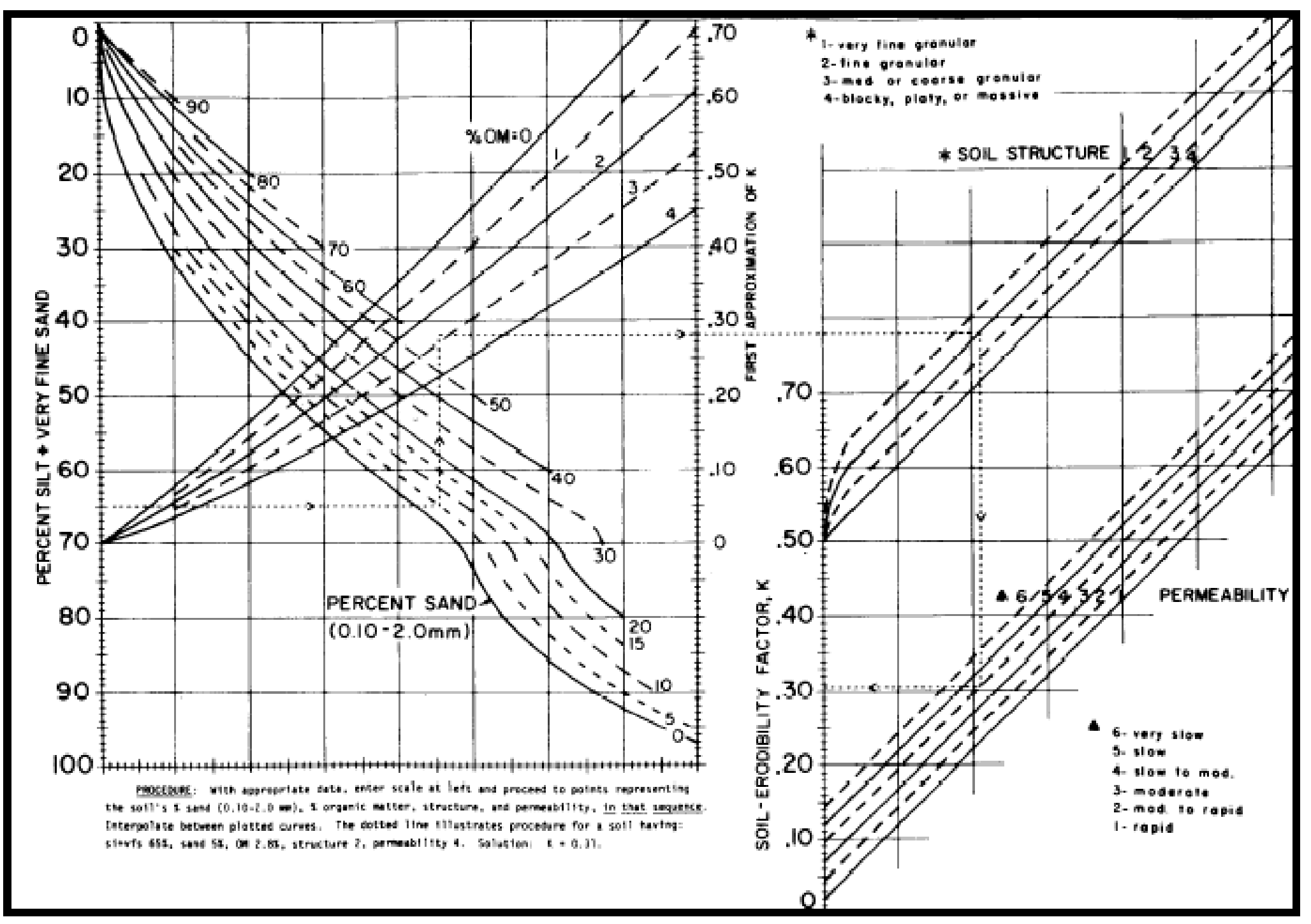


Figure 3. Slope-effect chart used to obtain the topographic (LS) factor (US

Department of Agriculture, Soil Conservation Service, 1977).

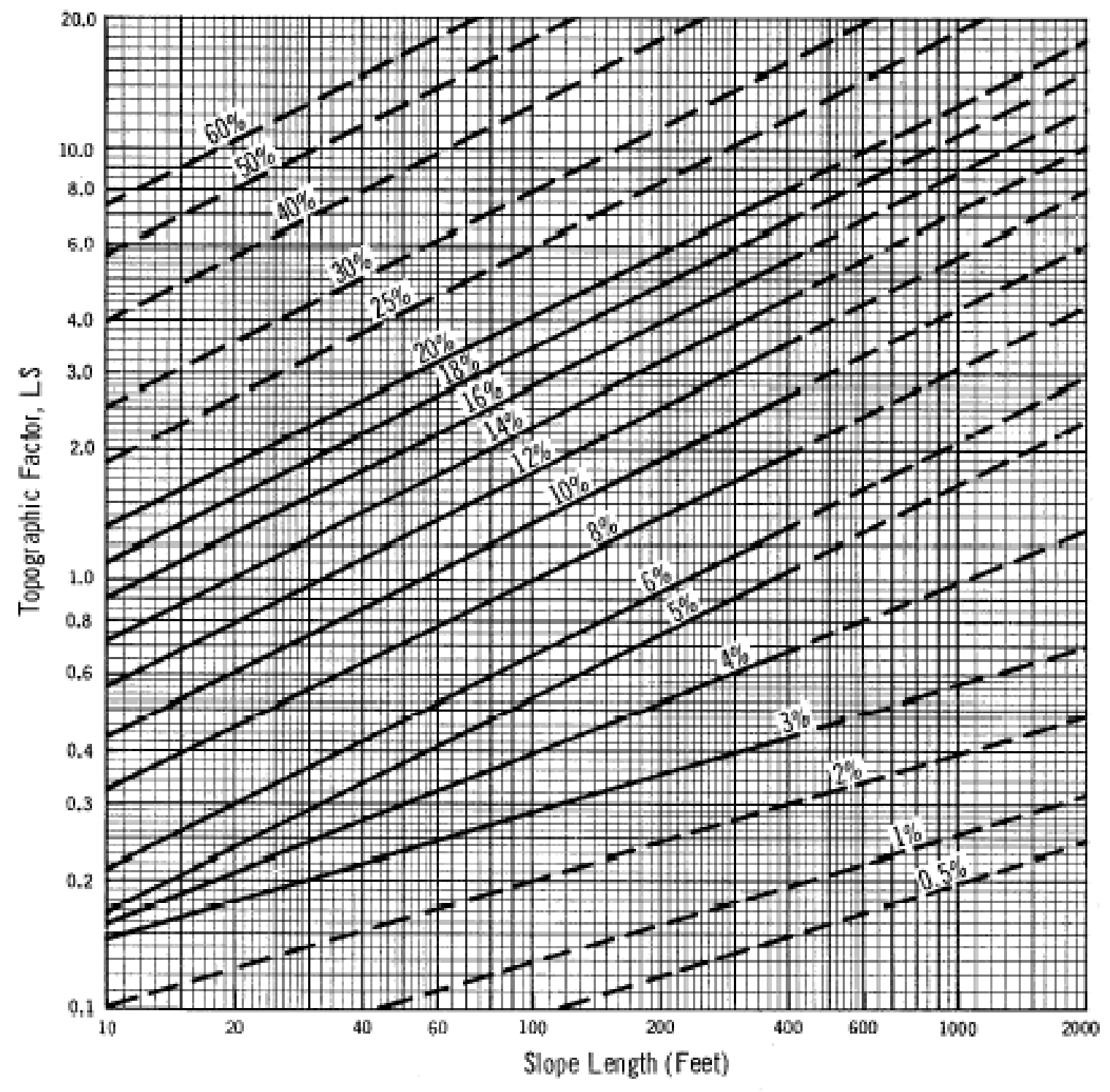


riffle ratio. The cluster analysis based on selected variables determined from discriminant analysis was performed using the Furthest-neighbor linkage method, and using distance coefficients. This method focused on the properties of the available sample (Swan and Sandilands, 1995). Categories can be defined based on clusters of points. These points represent individual reaches plotted in space. Points in the same cluster tend to be more similar than points in different clusters. The clusters were presented as a dendrogram with each stream reach as the roots.

\section{RESULTS AND DISCUSSION}

\subsection{BASIN RELATIONSHIPS}

\subsubsection{Drainage Area and Reach Establishment}

Of the three streams included in this study, Slaty Fork had the largest drainage area $\left(0.16 \mathrm{~km}^{2}\right)$ and an average gradient of 5.6 percent for its total length. Nine reaches were established and surveyed in this basin; one steep-cobble three aggrading, three incising, and two having both incising and aggrading characteristics (Table 6).

Sphagnum Run had a smaller drainage area than Slaty Fork $\left(0.09 \mathrm{~km}^{2}\right)$ and had the highest average gradient ( 6.4 percent) for its total length. This stream was comprised of five reaches; two steep-cobble, one step-pool and, and two wetland (Table 7). There were few bedrock exposures, and wetland and step-pool reaches were unique to this basin.

Larch Run watershed was slightly smaller than Slaty Fork $\left(0.14 \mathrm{~km}^{2}\right)$. Larch Run basin was comprised of eight reaches: two steep-cobble, three aggrading, two bedrock, and one transitional 
Table 6. Morphological characteristics of Slaty Fork stream reaches.

\begin{tabular}{|c|c|c|c|c|c|c|c|}
\hline Reach & Description & $\begin{array}{l}\text { Reach } \\
\text { Length } \\
(\mathrm{m})\end{array}$ & $\begin{array}{l}\text { Slope } \\
(\mathrm{m} / \mathrm{m})\end{array}$ & $\begin{array}{l}\text { Bankfull } \\
\text { Width } \\
(\mathrm{m})\end{array}$ & $\begin{array}{c}\text { ER } \\
(\mathrm{m} / \mathrm{m})\end{array}$ & $\begin{array}{l}\text { W/D } \\
\text { ratio } \\
(\mathrm{m} / \mathrm{m})\end{array}$ & $\begin{array}{l}\text { Sinuosity } \\
(\mathrm{m} / \mathrm{m})\end{array}$ \\
\hline 1 & $\begin{array}{l}\text { Aggrading, while bank height and sediment in } \\
\text { the streambed increase proportionally } \\
\text { downstream. The upper portion is a headcut. } \\
\text { Dominant channel materials are gravel. }\end{array}$ & 86 & 9.53 & 1.50 & 1.40 & 24.20 & 1.12 \\
\hline 2 & $\begin{array}{l}\text { Aggrading with banks reaching as high as } 9 \\
\text { meters. Bank instability contributes } \\
\text { significantly to sediment load. Dominant } \\
\text { channel materials are gravel and cobble. } \\
\text { Bankfull width is variable. }\end{array}$ & 159 & 8.64 & 4.00 & 1.60 & 2.20 & 1.31 \\
\hline 3 & $\begin{array}{l}\text { Erosive with a small transition from an } \\
\text { aggrading to erosional channel at the } \\
\text { beginning of the reach. Dominant channel } \\
\text { materials are gravel, while most of the channel } \\
\text { bed is smooth bedrock. }\end{array}$ & 87.5 & 6.72 & 1.00 & 0.30 & 7.80 & 1.07 \\
\hline 4 & $\begin{array}{l}\text { Transitional, upper portion is erosive, while } \\
\text { lower portion is aggrading. Primarily aggading } \\
\text { with gravel and bedrock are the dominant } \\
\text { channel materials. }\end{array}$ & 112 & 4.45 & 6.90 & 1.80 & 83.20 & 1.22 \\
\hline 5 & $\begin{array}{l}\text { Aggrading, old road crosses streambed. } \\
\text { Banks are low, reaching } 0.6 \text { meters in height. } \\
\text { Dominant channel materials are gravel. } \\
\text { Streambed resembles a braided channel. }\end{array}$ & 63 & 3.80 & 4.80 & 3.60 & 28.60 & 1.51 \\
\hline 6 & $\begin{array}{l}\text { Aggrading, while channel is not as wide and } \\
\text { banks are higher than previous reach. } \\
\text { Dominant channel materials are gravel. }\end{array}$ & 93 & 2.90 & 3.20 & 2.40 & 31.30 & 1.49 \\
\hline 7 & $\begin{array}{l}\text { Erosive, abrupt change of channel bed } \\
\text { materials with slope. Dominant channel } \\
\text { materials are gravel, while channel bed is } \\
\text { smooth bedrock. }\end{array}$ & 40.5 & 3.95 & 2.80 & 1.30 & 14.30 & 1.06 \\
\hline 8 & $\begin{array}{l}\text { Aggrading, abrupt change of channel bed with } \\
\text { slope. Dominant channel materials are gravel. }\end{array}$ & 71 & 2.63 & 2.50 & 2.30 & 18.90 & 1.07 \\
\hline 9 & $\begin{array}{l}\text { Erosive, abrupt change of channel bed with } \\
\text { slope. The channel bed is bedrock, while } \\
\text { channel materials are minimal. }\end{array}$ & 88 & 6.81 & 3.20 & 1.70 & 36.00 & 1.40 \\
\hline $\begin{array}{l}\text { Total } \\
\text { stream }\end{array}$ & $\begin{array}{l}\text { Drainage area of } 155,221 \text { meters squared. } \\
\text { Comprised of nine reaches; four aggrading, } \\
\text { three erosive, and two transitional. }\end{array}$ & 800 & 5.49 & 3.32 & 1.82 & 27.39 & 1.24 \\
\hline
\end{tabular}


Table 7. Morphologic characteristics of Sphagnum Run stream reaches.

\begin{tabular}{|c|c|c|c|c|c|c|c|}
\hline Reach & Description & $\begin{array}{l}\text { Reach } \\
\text { Length } \\
(\mathrm{m})\end{array}$ & $\begin{array}{l}\text { Slope } \\
(\mathrm{m} / \mathrm{m})\end{array}$ & $\begin{array}{c}\text { Bankfull } \\
\text { Width } \\
(\mathrm{m})\end{array}$ & $\begin{array}{c}\text { ER } \\
(\mathrm{m} / \mathrm{m})\end{array}$ & $\begin{array}{l}\text { W/D } \\
\text { ratio } \\
(\mathrm{m} / \mathrm{m})\end{array}$ & $\begin{array}{l}\text { Sinuosity } \\
(\mathrm{m} / \mathrm{m})\end{array}$ \\
\hline 1 & $\begin{array}{l}\text { Aggrading with steep gradient. } \\
\text { Left bank graded for road bed } \\
\text { and is significantly shorter than } \\
\text { right bank. Dominant channel } \\
\text { materials are gravel. }\end{array}$ & 110.01 & 6.91 & 1.10 & 1.40 & 11.70 & 1.12 \\
\hline 2 & $\begin{array}{l}\text { Stable channel flows through } \\
\text { wetland. Lower slope } \\
\text { separating two steep slopes. } \\
\text { Dominant channel materials are } \\
\text { gravel }\end{array}$ & 79.504 & 4.65 & 5.00 & 6.50 & 45.70 & 1.08 \\
\hline 3 & $\begin{array}{l}\text { Relatively stable step-pool } \\
\text { reach with a very steep } \\
\text { gradient. Dominant channel } \\
\text { materials are gravel and cobble. }\end{array}$ & 52.60 & 12.72 & 1.90 & 1.80 & 20.90 & 1.17 \\
\hline 4 & $\begin{array}{l}\text { Aggrading and sinuos with a } \\
\text { lower slope than previous } \\
\text { reach. Dominant channel } \\
\text { materials are gravel and cobble. }\end{array}$ & 52.7 & 5.39 & 1.90 & 1.90 & 15.40 & 1.23 \\
\hline 5 & $\begin{array}{l}\text { Stable channel with gentle } \\
\text { gradient. Flows through } \\
\text { wetland. Dominant channel } \\
\text { materials are gravel }\end{array}$ & 239.01 & 2.47 & 3.00 & 1.40 & 108.90 & 0.40 \\
\hline $\begin{array}{c}\text { Total } \\
\text { Stream }\end{array}$ & $\begin{array}{l}\text { Drainage area of } 88,261 \text { meters } \\
\text { squared. Comprised of five } \\
\text { reaches; two aggrading, two } \\
\text { wetland, and one step-pool }\end{array}$ & 533.82 & 6.43 & 2.58 & 2.60 & 40.52 & 1.00 \\
\hline
\end{tabular}


Table 8. Morphologic characteristics of Larch Run stream reaches.

\begin{tabular}{|c|c|c|c|c|c|c|c|}
\hline Reach & Description & $\begin{array}{l}\text { Reach } \\
\text { Length } \\
(\mathrm{m})\end{array}$ & $\begin{array}{l}\text { Slope } \\
(\mathrm{m} / \mathrm{m})\end{array}$ & $\begin{array}{l}\text { Bankfull } \\
\text { Width } \\
\text { (m) }\end{array}$ & $\begin{array}{l}\text { ER } \\
(\mathrm{m} / \mathrm{m})\end{array}$ & $\begin{array}{l}\text { W/D } \\
\text { ratio } \\
(\mathrm{m} / \mathrm{m})\end{array}$ & $\begin{array}{l}\text { Sinuosity } \\
(\mathrm{m} / \mathrm{m})\end{array}$ \\
\hline 1 & $\begin{array}{l}\text { Aggrading and sinuos with a steep } \\
\text { gradient. Dominant channel materials } \\
\text { are gravel and cobble. Reach ends at } \\
\text { an old road bed. }\end{array}$ & 245.01 & 0.50 & 8.48 & 1.6 & 18.70 & 2.33 \\
\hline 2 & $\begin{array}{l}\text { Aggrading with steep, moderately } \\
\text { sloping banks. Dominant channel } \\
\text { materials are gravel. Upstream portion } \\
\text { of the reach flows over a road and } \\
\text { through a culvert. }\end{array}$ & 52.00 & 3.20 & 4.50 & 1.7 & 30.60 & 1.44 \\
\hline 3 & $\begin{array}{l}\text { Aggrading with variable bank height } \\
\text { and channel width. Dominant channel } \\
\text { materials are gravel. Streambed } \\
\text { resembles a braided channel. }\end{array}$ & 49.71 & 7.30 & 3.68 & 1.4 & 73.20 & 1.02 \\
\hline 4 & $\begin{array}{l}\text { Aggrading with a steep gradient.. } \\
\text { Dominant channel materials are gravel, } \\
\text { while cobble occurs relatively } \\
\text { frequently. Step pools occur in the } \\
\text { lower portion. }\end{array}$ & 82.30 & 5.00 & 6.14 & 1.8 & 23.70 & 1.74 \\
\hline 5 & $\begin{array}{l}\text { Transitional reach primarily comprised } \\
\text { of bedrock. The dominant channel } \\
\text { materials are bedrock, while gravel } \\
\text { occurs less frequently. Channel width } \\
\text { is significantly smaller than previous } \\
\text { reach. }\end{array}$ & 40.20 & 1.90 & 3.87 & 1.6 & 17.40 & 1.12 \\
\hline 6 & $\begin{array}{l}\text { Erosive reach with a steep gradient. } \\
\text { Dominant channel materials are } \\
\text { bedrock, while gravel occurs less } \\
\text { frequently. }\end{array}$ & 39.72 & 1.90 & 6.89 & 1 & 41.60 & 1.10 \\
\hline 7 & $\begin{array}{l}\text { Abrupt change from smooth bedrock to } \\
\text { aggrading. Dominant channel } \\
\text { materials are gravel, while cobble } \\
\text { occurs relatively frequently. }\end{array}$ & 103.21 & 3.00 & 5.00 & 1.2 & 25.80 & 1.11 \\
\hline 8 & $\begin{array}{l}\text { Aggrading with variable channel width. } \\
\text { Dominant channel materials are gravel. }\end{array}$ & 90.89 & 3.80 & 2.60 & 1.3 & 30.60 & 1.06 \\
\hline $\begin{array}{l}\text { Total } \\
\text { Stream }\end{array}$ & $\begin{array}{l}\text { Drainage area of } 143,522 \text { meters } \\
\text { squared. Comprised of eight reaches; } \\
\text { five aggrading, two bedrock, and one } \\
\text { transitional. }\end{array}$ & 703.03 & 3.33 & 5.15 & 1.45 & 32.70 & 1.62 \\
\hline
\end{tabular}


(having both bedrock and aggrading characteristics) (Table 8). The average percent gradient for this tributary was 5 percent.

In each stream, the upstream extent of surveying began where the first significant ( $>0.5 \mathrm{~m})$ channel occurs. Surveyed lengths for Slaty Fork, Sphagnum Run, and Larch Run were 800, 534, and 703 m, respectively, upstream from Rt. 93.

\subsubsection{Vegetation}

Vegetative cover for the three streams ranged from 3 to 88 percent: Slaty Fork with 3-55 percent, Sphagnum with 4-88 percent, and Larch Run with 14-32 percent. Red pines (Pinus resinosa Ait.), scotch pines, autumn olive (Elaegnus umbellate Thunb.), New York ferns (Thelypteris noveboracensis Nieuwl.), and blueberry (Vaccinium spp Ait.) dominated the vegetation surrounding the three streams. In addition, sphagnum moss (Cymbifolium spp), hair-cap moss (Polytrichum spp), sedges (Scirpus spp), and cottonweed (Froelichia spp) dominated wetland reaches of Sphagnum Run. Seeps occurred in Larch Run reach two and at the uppermost portion of reach three resulting in isolated pockets of wetland vegetation.

\subsection{EXTERNAL INFLUENCES}

External variables included soil properties of the streambanks (particle sizes, aggregate stability, organic matter content, $\mathrm{pH}$, and percent rock fragment), percent vegetation coverage on streambanks, and the number and type of bank instabilities observed. Analysis of external variables was used to define relationships 1) among external variables and 2) among external and morphological variables. 


\subsubsection{Soil Properties}

\subsubsection{Soil Characteristics per Stream}

Soil samples collected from streambanks were used to further describe soils surrounding the three steams. Soils from Slaty Fork streambanks had the most variable textures, with generally more clay than the other streams. These soils had the lowest average organic matter values, $\mathrm{pH}$ and vegetation percentages. Slaty Fork soils also had the highest rock fragment percentages. Soil pits 3 and 4 were closest in proximity to Slaty Fork (Figure 1).

The primary texture of soils surrounding Larch Run was loam. These soils had the lowest average aggregate stability values of all the sites, and rock fragment and vegetation percentages were similar to the soils surrounding Slaty Fork.

Soils along Sphagnum Run generally had more silt than soils along other streams. Silt loam and silty clay loam were the dominant textures of the soils collected from streambanks of Sphagnum Run. Silty clay loam textures were generally found in wetland reaches. Soil pit 2 was adjacent to Sphagnum reach 2. This soil was wet, but not reduced. The water table was encountered about $120 \mathrm{~cm}$ from the soil surface. This may indicate that there is a perched watertable in the area, influencing the existence of the upstream wetland reach. Soil pit one was located between Sphagnum and Larch Run.

\subsubsection{Aggregate Stability}

Soil erodibility is an important factor in channel formation and development. Aggregate stability produces a reliable description and ranking of the resistance of soil structural aggregates to breakdown when subjected to disruptive processes. Soil aggregation is the formation of aggregates through the bonding of sand, silt, and clay, and 
their stabilization by organic and inorganic binding materials. The wet-sieve method used in this study simulated the action of wetting and measures slaking forces exerted on a soil by flowing water.

Aggregate stability analysis for all three streams was pooled together to determine if aggregate stability had an influence on other soil properties or geomorphic variables. Natural breaks in data were used to group reaches that had similar aggregate stability values. Aggregate stability groups of $<20 \%, 20-30 \%$, and $>30 \%$ were established for

parameter comparison. A comparison of aggregate stability versus (a) external variables and (b) channel characteristics is shown in Tables 9a and 9b. Large standard deviation values and box and whisker plots showed wide data ranges in aggregate stability comparisons (Figure 4a-c).

\subsubsection{Organic Matter Content}

The loss on ignition method used to determine organic matter content of the soils proved unreliable. Soils contained coal particulates that combusted along with organic matter, resulting in extremely high organic matter values. Organic matter content was also determined from particle size analysis. The initial step of this method, removes organic matter with hydrogen peroxide. This method is not recommended to determine organic matter content because it is difficult to determine when all organic matter has been removed. Once again, problems occurred because coal particulates caused frothing to continue for extended time periods. Consequently, samples were treated with hydrogen peroxide for one week. Although, this method also produced high organic 
Table 9a. Relation of aggregate stability and external variables.

\begin{tabular}{|c|c|c|c|c|c|c|c|c|c|c|c|c|}
\hline $\begin{array}{l}\text { Aggregate } \\
\text { Stability (\%) }\end{array}$ & $\begin{array}{c}\text { Mean } \\
\text { Organic } \\
\text { Matter } \\
(\%)\end{array}$ & SD & $\begin{array}{c}\text { Mean } \\
\text { Vegetation } \\
(\%)\end{array}$ & SD & $\begin{array}{c}\text { Mean Rock } \\
\text { Fragments } \\
(\%)\end{array}$ & SD & $\begin{array}{c}\text { Mean } \\
\text { Clay } \\
(\%)\end{array}$ & SD & $\begin{array}{c}\text { Mean } \\
\text { Silt } \\
(\%)\end{array}$ & SD & $\begin{array}{c}\text { Mean } \\
\text { Sand } \\
(\%)\end{array}$ & SD \\
\hline$<20$ & 3.96 & 2.23 & 24.78 & 15.03 & 34.03 & 22.15 & 28.75 & 8.34 & 42.71 & 6.02 & 28.55 & 10.25 \\
\hline $20-30$ & 4.53 & 1.73 & 32.50 & 23.08 & 25.08 & 11.69 & 26.30 & 9.74 & 48.40 & 4.94 & 25.30 & 12.25 \\
\hline$>30$ & 7.79 & 3.75 & 32.92 & 29.90 & 15.17 & 8.01 & 23.36 & 5.08 & 48.93 & 4.06 & 27.71 & 6.50 \\
\hline
\end{tabular}

Table 9b. Relation of aggregate stability and channel morphology

\begin{tabular}{|c|c|c|c|c|c|c|c|c|c|c|c|c|}
\hline $\begin{array}{c}\text { Aggregate } \\
\text { Stability } \\
(\%)\end{array}$ & $\begin{array}{c}\text { Mean } \\
\text { Slope } \\
(\%)\end{array}$ & SD & $\begin{array}{c}\text { Mean } \\
\text { Entrenchment } \\
\text { Ratio } \\
(\mathrm{m} / \mathrm{m})\end{array}$ & SD & $\begin{array}{l}\text { Mean W/D } \\
\text { Ratio }\end{array}$ & SD & $\begin{array}{c}\text { Mean } \\
\text { Sinuosity } \\
(\mathrm{m} / \mathrm{m})\end{array}$ & SD & $\begin{array}{l}\text { Mean } \\
\text { Bankfull } \\
\text { Width } \\
(\mathrm{m})\end{array}$ & SD & $\begin{array}{c}\text { Mean } \\
\text { Bank } \\
\text { Height } \\
\text { (m) }\end{array}$ & SD \\
\hline$<20$ & 5.11 & 1.82 & 1.60 & 0.83 & 26.45 & 19.78 & 1.22 & 0.18 & 3.16 & 2.27 & 2.95 & 1.66 \\
\hline $20-30$ & 4.82 & 1.47 & 1.77 & 0.50 & 33.20 & 18.95 & 1.26 & 0.21 & 3.96 & 2.75 & 2.65 & 1.83 \\
\hline$>30$ & 7.12 & 4.02 & 1.65 & 0.36 & 32.15 & 32.76 & 1.20 & 0.63 & 2.99 & 1.58 & 3.17 & 2.62 \\
\hline
\end{tabular}



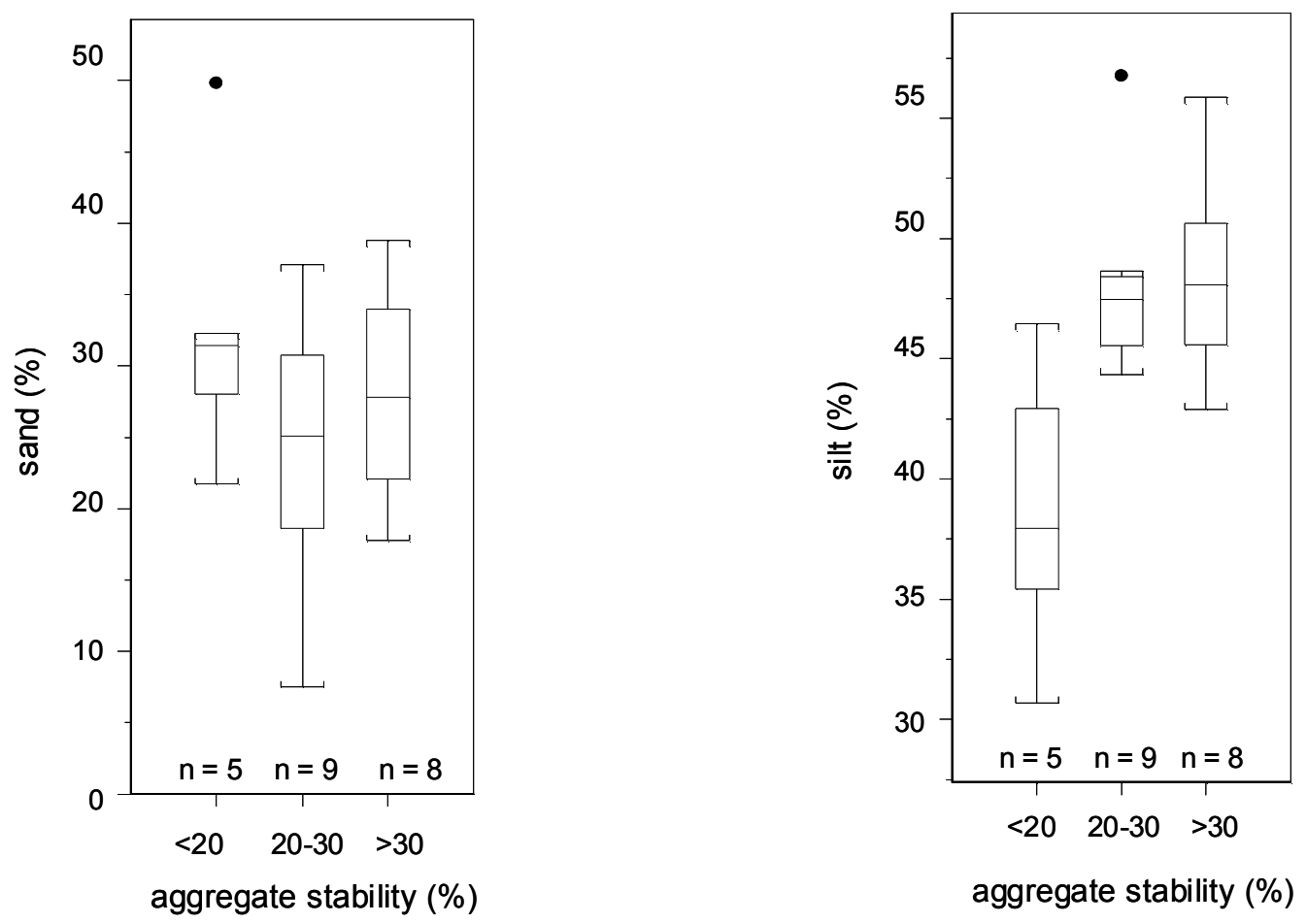

(a)

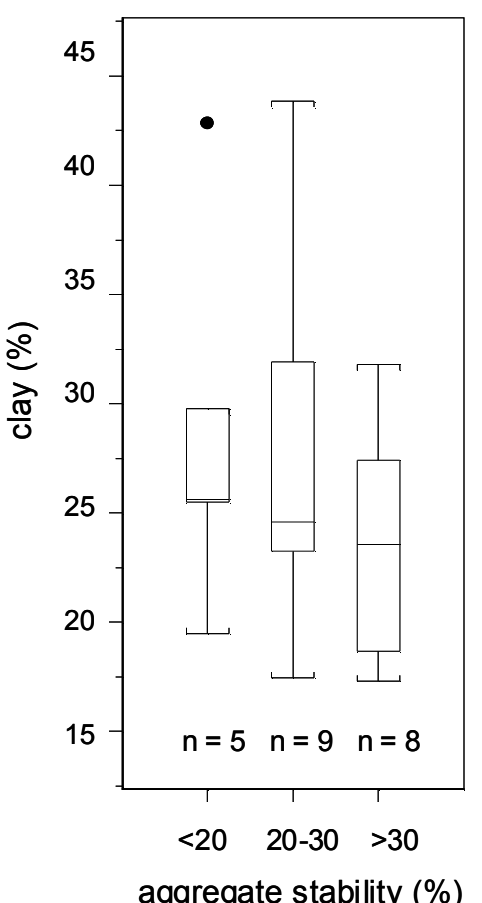

(b)

(c)

FIGURE 4. Comparison of sand content (a), silt content (b), and clay content (c) as a function of aggregate stability. 
matter values, the results appeared more reasonable. However, neither method generated reliable results. Organic matter content is given in Appendix C.

\subsubsection{Bank Failures}

Bank failures were evident in all three streams. The most common bank failures resulted from undercut banks. Cut banks generated cantilevers and exposed tree roots resulting in tree falls across the channel bed. Exposed soil from tree falls was vulnerable to flows and generated further erosion. Gulleys and slumps occurred less frequently in upstream reaches.

Slaty Fork and Larch Run had significantly more bank failures than Sphagnum Run (Tables 10-12). Twenty-one undercut banks (Figure 5) were observed for both Slaty Fork and Larch Run. Most undercut banks occurred in areas where bedrock was exposed on the channel bottom. Cut banks occurred regularly throughout the upper eight reaches of Slaty Fork; six undercut banks were found in reach nine. Cut banks were irregularly distributed throughout Larch Run; reach one and seven both contained seven cut banks, while reach two did not have any.

Less common, gulleys (Figure 6) occurred in Slaty Fork and Larch Run. Gulleys were common on the banks of reaches two and three of Slaty Fork; less common, fewer, and smaller gulleys were found in reaches three and eight of Larch Run. A slump occurred in reach one of both Slaty Fork and Larch Run (Figure 7). 
Table 10. Streambank characteristics of Slaty Fork.

\begin{tabular}{|c|c|c|c|c|c|c|}
\hline Reach & Bank Characteristics & $\begin{array}{c}\text { Bank } \\
\text { Height } \\
\text { (m) }\end{array}$ & $\begin{array}{l}\text { Bank Angle } \\
\text { (degrees) }\end{array}$ & $\begin{array}{l}\mathrm{K} \\
\text { Factor }\end{array}$ & $\begin{array}{l}\text { LS } \\
\text { Factor }\end{array}$ & $\begin{array}{l}\text { BEHI } \\
\text { Rating }\end{array}$ \\
\hline
\end{tabular}

Bank height generally increases in the

1 downstream direction. Banks relatively stable. Undercut bank and slump occur in the lower

1.10

65

$0.24 \quad 4.91$

33.30

protion of the reach. No bedrock visible.

Steep banks. Many gulleys in upper portion of reach. Two undercut banks in the lower

2 portion, one occurs with bedrock exposure.

Seep located at the toe of the bank created a

55

$0.24 \quad 9.25$

35.10 ledge in streambed.

Gulleys present on left bank. Two seeps occur

3 at the toe of banks. Ledge and undercut bank result from lower seep. Undercut bank occurs with bedrock exposure.

Two undercut banks present. Two trees

4 leaning across stream due to root exposure from cut banks.

Relatively stable. Lower banks due to grading. Old road runs across streambed. Large bend

5 with extreme cut bank. Four bedrock exposures lining channel bed with one undercut bank.

Banks not affected by grading. Stream flows directly into bank causing a change in flow direction and a severely cut bank. Trees lying

6 across stream bed due to cut bank. Remainder of reach is relatively stable.

Bedrock lines the channel in the upper portion with one slightly undercut bank.

Three undercut banks. Large tree is severely

7 undercut with roots exposed. Channel is comprised of bedrock.

$\begin{array}{lllll}0.60 & 38 & 0.25 & 1.64 & 27.80\end{array}$

$\begin{array}{lllll}4.00 & 53 & 0.23 & 7.04 & 36.50\end{array}$

Two slight to moderate undercut banks.

8 Bedrock exposure occurs with one undercut bank.

$\begin{array}{lllll}4.10 & 48 & 0.23 & 4.77 & 34.00\end{array}$

Six severely undercut banks exposing tree

9 roots. Two trees fallen over stream bed due to cut root exposures from cut banks. Channel is comprised of bedrock. 
Table 11. Streambank characteristics of Larch Run.

\begin{tabular}{|c|c|c|c|c|c|c|}
\hline Reach & Bank Characteristics & $\begin{array}{l}\text { Bank } \\
\text { Height } \\
(\mathrm{m})\end{array}$ & $\begin{array}{c}\text { Bank Angle } \\
\text { (degrees) }\end{array}$ & $\begin{array}{c}\mathrm{K} \\
\text { Factor }\end{array}$ & $\begin{array}{l}\text { LS } \\
\text { Factor }\end{array}$ & $\begin{array}{l}\text { BEHI } \\
\text { Rating }\end{array}$ \\
\hline 1 & $\begin{array}{l}\text { Bank height variable. Upper portion of } \\
\text { reach is unstable with seven undercut } \\
\text { banks. Slump gradually lowering } \\
\text { boulder to channel bed. Bank erosion } \\
\text { and cut banks exposing tree roots. }\end{array}$ & 1.5 & 53 & 0.25 & 4.31 & 38.9 \\
\hline 2 & $\begin{array}{l}\text { Steep, vegetated banks that are } \\
\text { relatively stable. Three seeps occur at } \\
\text { toe of banks. Seeps comprised of } \\
\text { resistant materials that create } \\
\text { overhaning ledges. }\end{array}$ & 4 & 61 & 0.23 & 8.59 & 37.8 \\
\hline 3 & $\begin{array}{l}\text { Bank height varible. Few gulleys } \\
\text { present. Two undercut banks with one } \\
\text { tree leaning over stream due to root } \\
\text { exposure. Two seeps occur at toe of } \\
\text { banks. }\end{array}$ & 0.9 & 43 & 0.22 & 2.44 & 37.9 \\
\hline 4 & $\begin{array}{l}\text { Relatively stable banks. Right bank } \\
\text { leveled for old road bed and is } \\
\text { significantly lower than the left bank. } \\
\text { Undercut bank at lower portion of reach } \\
\text { were bedrock is exposed. }\end{array}$ & 3.5 & 55 & 0.25 & 6.95 & 33.2 \\
\hline 5 & $\begin{array}{l}\text { Right bank leveled for old road bed, } \\
\text { while left bank is generally the same } \\
\text { height. Two undercut banks. Long } \\
\text { undercut bank occurs in the upper } \\
\text { portion of the reach. Channel } \\
\text { comprised of bedrock. }\end{array}$ & 0.6 & 56 & 0.26 & 2.95 & 35.1 \\
\hline 6 & $\begin{array}{l}\text { Right bank leveled for old road bed and } \\
\text { is significantly lower than the left bank. } \\
\text { Two long undercut banks. Channel } \\
\text { comprised of bedrock. }\end{array}$ & 4.6 & 59 & 0.23 & 8.80 & 35.5 \\
\hline 7 & $\begin{array}{l}\text { Right bank leveled for old road bed and } \\
\text { is significantly lower than the left banks. } \\
\text { Seven undercut banks. Five cut banks } \\
\text { occur with bedrock exposures. }\end{array}$ & 3.7 & 53 & 0.25 & 6.77 & 37.1 \\
\hline 8 & $\begin{array}{l}\text { Left bank leveled for old road bed and is } \\
\text { significantly lower than the right bank. } \\
\text { Few gulleys on left bank. }\end{array}$ & 2.9 & 49 & 0.24 & 5.34 & 36.8 \\
\hline
\end{tabular}


Table 12. Streambank characteristics of Sphagnum Run.

\begin{tabular}{|c|c|c|c|c|c|c|}
\hline Reach & Bank Characteristics & $\begin{array}{l}\text { Bank Height } \mathrm{B} \\
(\mathrm{m})\end{array}$ & $\begin{array}{l}\text { Bank Angle } \\
\text { (degrees) }\end{array}$ & $\begin{array}{c}\mathrm{K} \\
\text { Factor }\end{array}$ & $\begin{array}{l}\text { LS } \\
\text { Factor }\end{array}$ & $\begin{array}{l}\text { BEHI } \\
\text { Rating }\end{array}$ \\
\hline 1 & $\begin{array}{l}\text { Left bank leveled for old road bed and is } \\
\text { significantly lower than right bank. Five } \\
\text { cut banks occur in upper portion of reach. } \\
\text { Large, colluvial boulder caused a severe } \\
\text { cut bank severe with overhaning trees. }\end{array}$ & 5.5 & 62 & 0.22 & 10.30 & 44 \\
\hline 2 & $\begin{array}{l}\text { Stable, gently sloping, vegetated banks. } \\
\text { Channel runs through wetland with no } \\
\text { undercut areas present. }\end{array}$ & 0.8 & 2 & 0.22 & 0.06 & 24.6 \\
\hline 3 & $\begin{array}{l}\text { Two undercut banks. Channel is very } \\
\text { steep with step pools that dissipate } \\
\text { energy. }\end{array}$ & 4 & 28 & 0.24 & 3.75 & 32.9 \\
\hline 4 & $\begin{array}{l}\text { Three undercut banks. Tree leaning } \\
\text { across channel bed due to cut bank. }\end{array}$ & 1.8 & 48 & 0.22 & 4.02 & 37.1 \\
\hline 5 & $\begin{array}{l}\text { Stable, gently sloping, vegetated banks. } \\
\text { Channel runs through wetland with no } \\
\text { undercut areas present. }\end{array}$ & 0.3 & 2 & 0.22 & 0.01 & 17.7 \\
\hline
\end{tabular}


Three seeps were found in the upper reaches of Slaty Fork, while seven seeps were found in the upper reaches of Larch Run. Seeps generally occurred at the toe of the bank. Some seeps appeared to produce resistant bedrock ledges that created steps in the channel bed (Figure 8).

Sphagnum Run contained ten undercut banks. Reach one had five cut banks, while reaches two and five had none. The only bedrock exposure observed in this stream was associated with a severely cut bank. No seeps or slumps were found on the banks of this stream.

BEHI ratings were determined for each stream reach using methods developed by Rosgen (1996). Reaches were divided into groups based on BEHI rating values of $<30$ (low erosion risk), 30-35, 35-45, and $>45$ (high erosion risk) and compared with channel morphology and streambank characteristics in Table 13. High BEHI ratings were associated with low percent vegetation coverage, entrenched channels with low widthdepth ratios, and tall, steep banks. BEHI ratings and LS factor values corresponded closely. 


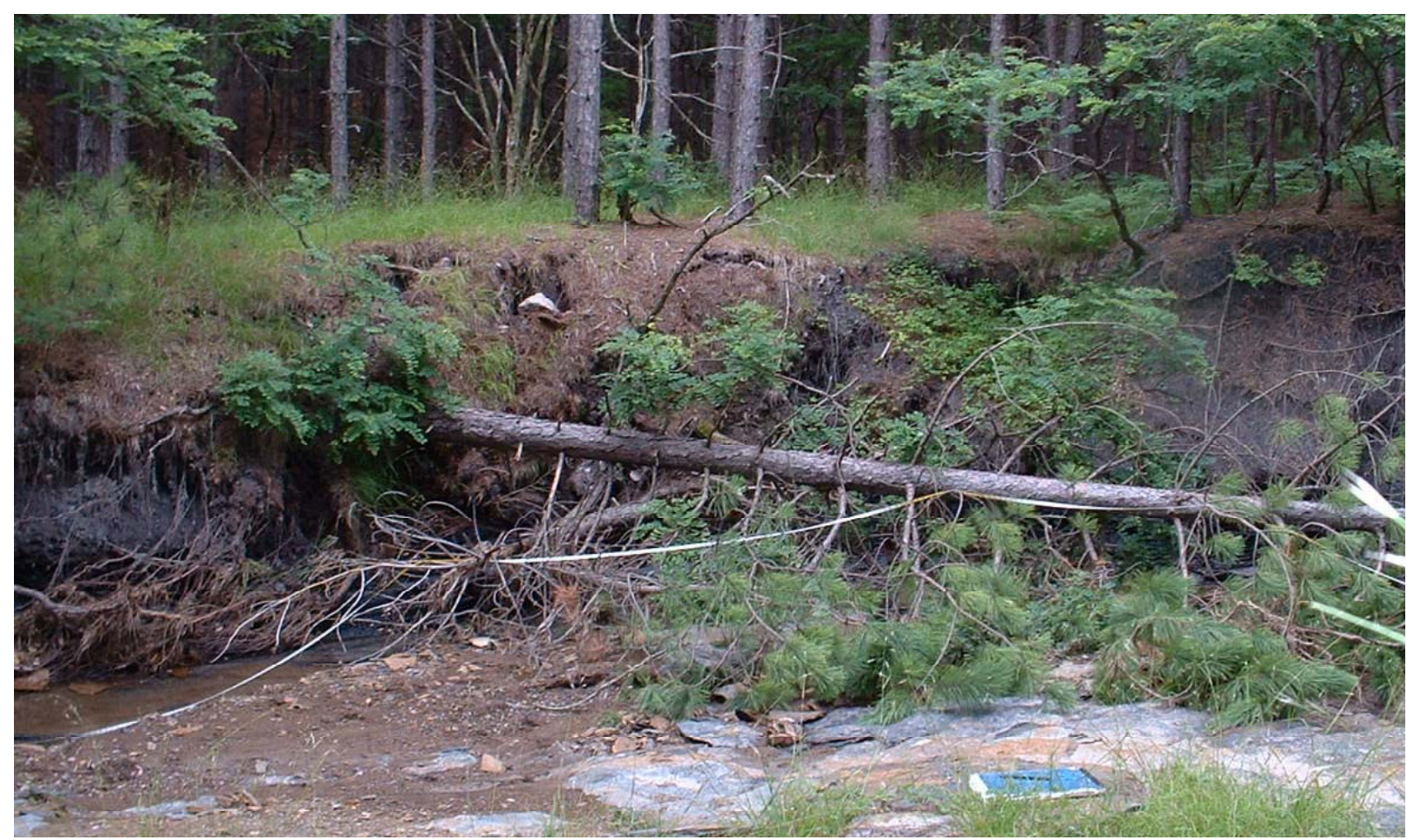

Figure 5. Undercut bank located in reach six of Slaty Fork.

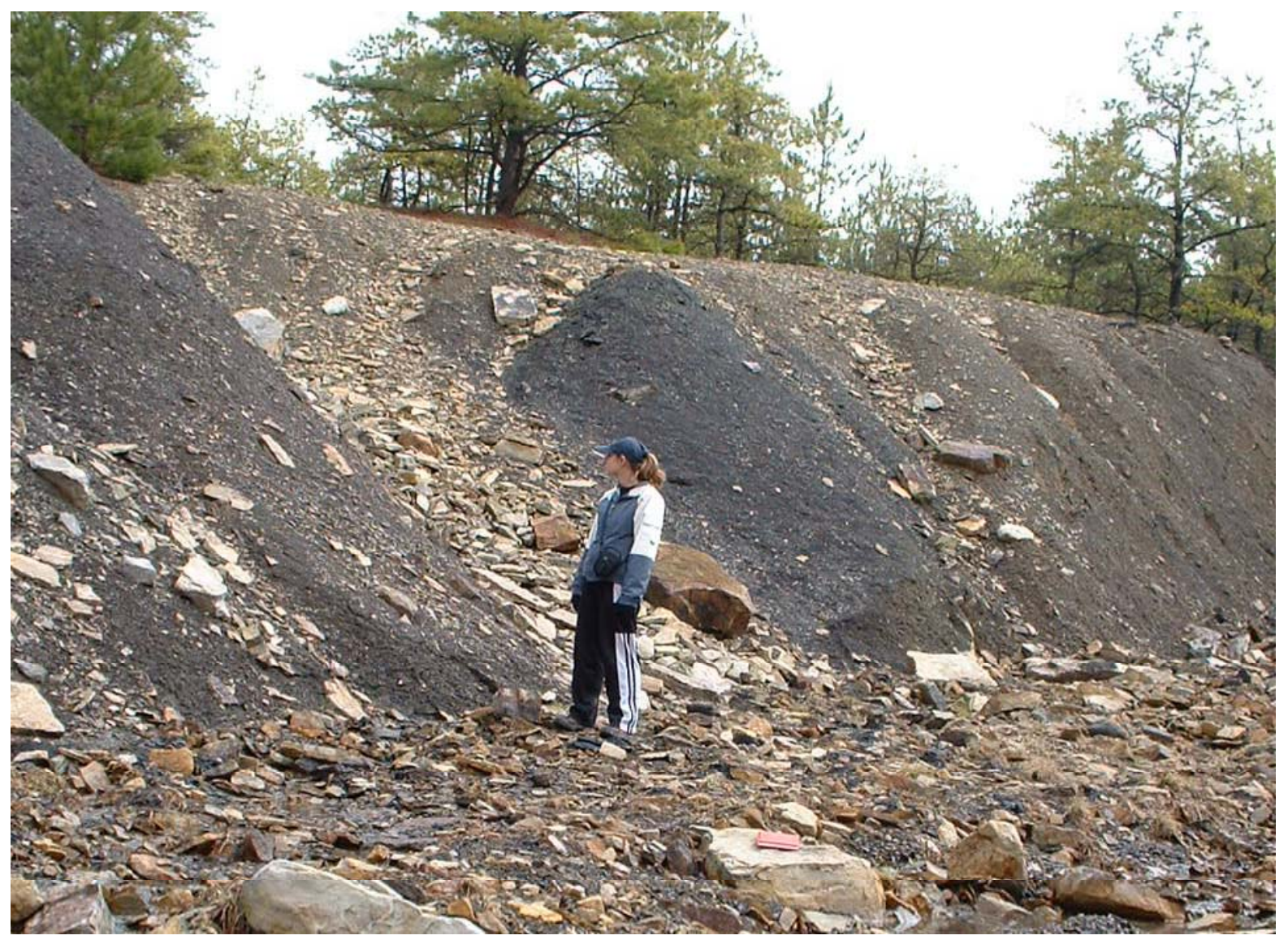

Figure 6. Gulleys on streambanks located in reach two of Slaty Fork. 


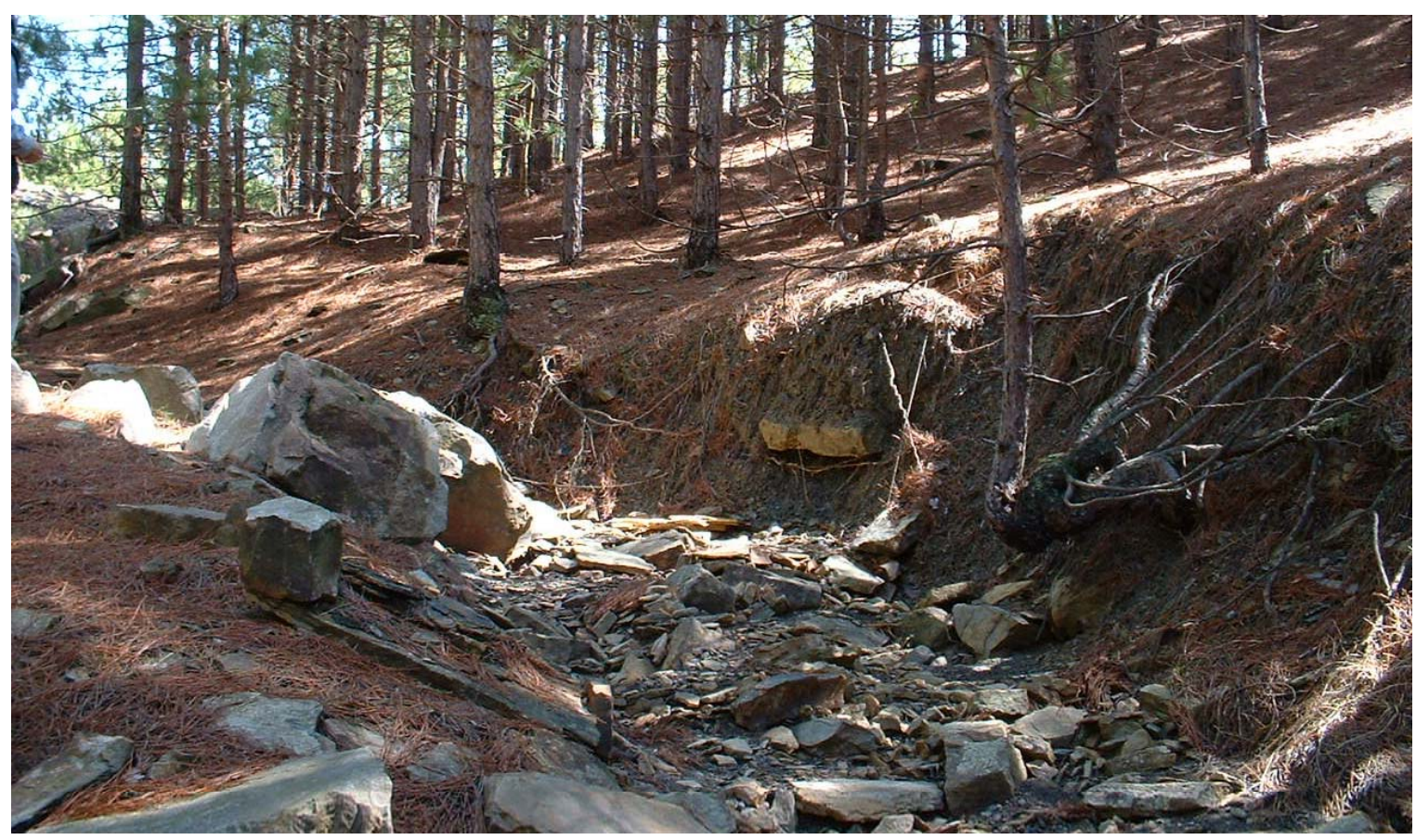

Figure 7. Slump located in reach one of Larch Run.

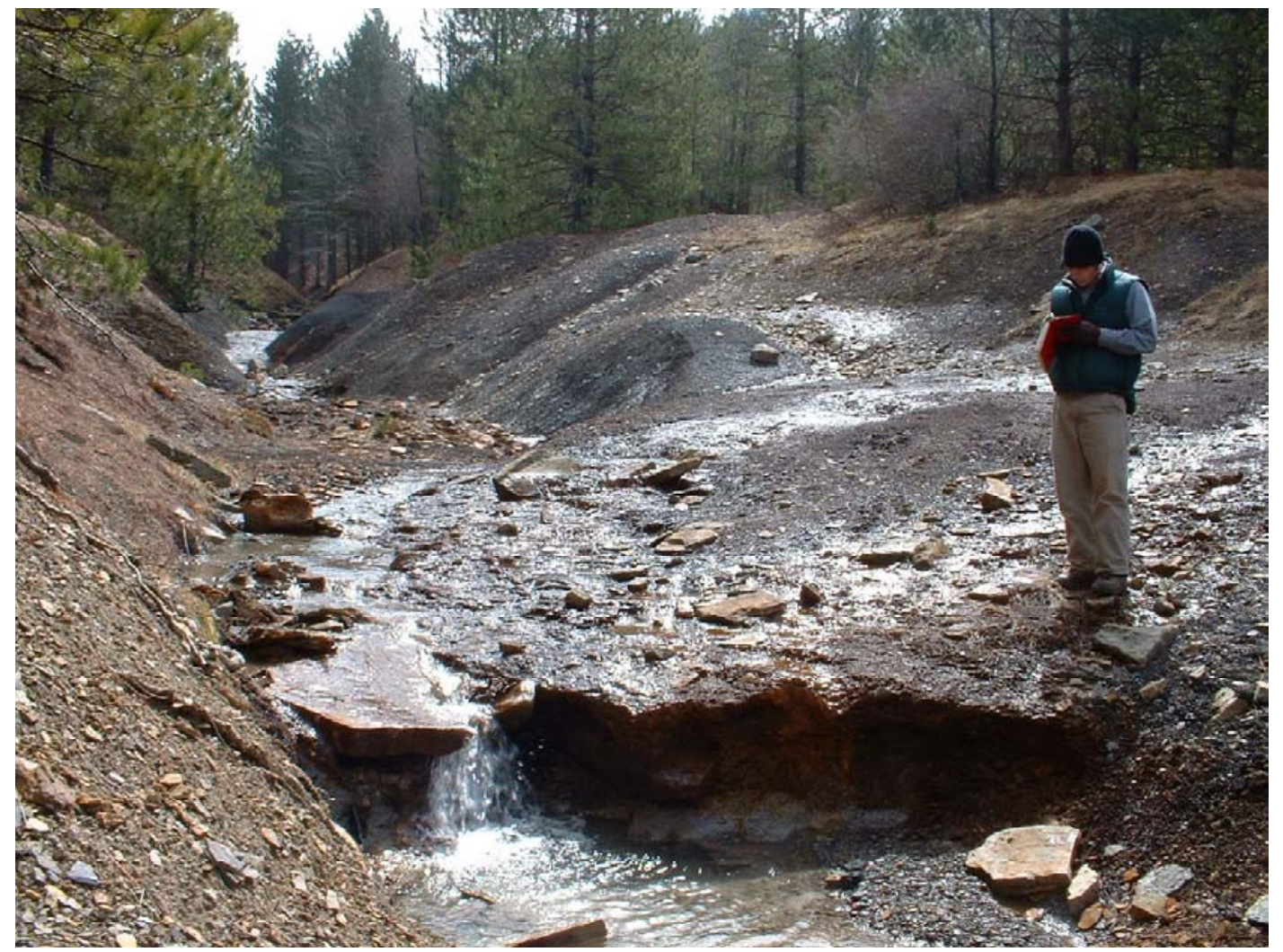

Figure 8. Seep with Ledge located in reach three of Slaty Fork 
Table 13. BEHI rating relationships with channel and bank characteristics.

\begin{tabular}{|c|c|c|c|c|c|c|c|c|c|c|c|c|c|c|}
\hline $\begin{array}{l}\text { BEHI } \\
\text { Rating }\end{array}$ & $\begin{array}{l}\text { Mean } \\
\text { LS } \\
\text { Factor }\end{array}$ & $S D$ & $\begin{array}{c}\text { Mean } \\
\text { Vegetation } \\
(\%)\end{array}$ & SD & $\begin{array}{l}\text { Mean } \\
\text { ER } \\
(\mathrm{m} / \mathrm{m})\end{array}$ & SD & $\begin{array}{l}\text { Mean } \\
\text { W/D } \\
\text { Ratio }\end{array}$ & SD & $\begin{array}{c}\text { Mean } \\
\text { Sinuosity } \\
(\mathrm{m} / \mathrm{m})\end{array}$ & $S D$ & $\begin{array}{c}\text { Mean } \\
\text { Bank } \\
\text { Height } \\
(\mathrm{m})\end{array}$ & SD & $\begin{array}{c}\text { Mean } \\
\text { Bank } \\
\text { Angle } \\
\text { (Degrees) }\end{array}$ & SD \\
\hline $30-35$ & 6.13 & 2.05 & 35.42 & 11.98 & 1.72 & 0.35 & 23.00 & 7.32 & 1.23 & 0.21 & 3.85 & 1.36 & 53.5 & 17.83 \\
\hline $35-45$ & 5.46 & 2.40 & 22.68 & 6.89 & 1.53 & 0.37 & 32.00 & 23.09 & 1.3 & 0.39 & 2.92 & 1.77 & 50.7 & 6.34 \\
\hline$>45$ & 8.26 & 2.22 & 10.33 & 12.71 & 1.13 & 0.74 & 16.7 & 12.19 & 1.21 & 0.20 & 4.5 & 1.73 & 56.67 & 8.39 \\
\hline
\end{tabular}




\subsubsection{Vegetation}

Vegetation coverage values for all three streams were pooled together to determine if coverage class had an influence on soil properties or geomorphic variables. Natural breaks in data were used to group reaches that had similar coverage classes. Percent vegetation coverage was divided into three groups; less than 25 percent to represent very sparse vegetation, 25 to 35 percent to represent sparse vegetation, and greater than 35 percent to represent moderate to good vegetation. Relationships between vegetation coverage and soil properties, bank characteristics, and morphological variables are shown in Tables 14a-c. Higher vegetation percentages corresponded with lower channel banks, lower D84 particle size, and lower BEHI ratings.

Greater vegetation coverage was found in areas with less acidity (Figure 9a). Soil texture did not appear to influence vegetation growth in this study area (Figures 9bd). Most soils in this study contained high silt and clay contents, however the highly variable vegetation growth on these sites was more likely related to soil $\mathrm{pH}$ rather than soil texture.

Percent vegetation coverage increased the erosional resistance of banks. Gulleys were only observed on un-vegetated or sparsely vegetated banks. Vegetation had little influence on bank failures caused by undercut banks or slumps. Roots provided some support for the banks, but generally the vegetation was defeated by the continuous flow of water. 
Table 14a. Relation of vegetation coverage and soil properties.

\begin{tabular}{ccccccccccccc}
\hline $\begin{array}{c}\text { Vegetation } \\
(\%)\end{array}$ & $\begin{array}{c}\text { Mean } \\
\text { Aggregate } \\
\text { Stability } \\
(\%)\end{array}$ & SD & $\begin{array}{c}\text { Mean } \\
\text { Organic } \\
\text { Matter } \\
(\%)\end{array}$ & SD & $\begin{array}{c}\text { Mean } \\
\text { Rock } \\
\text { Fragments } \\
(\%)\end{array}$ & SD & $\begin{array}{c}\text { Mean } \\
\text { Clay } \\
(\%)\end{array}$ & SD & $\begin{array}{c}\text { Mean } \\
\text { Silt } \\
(\%)\end{array}$ & $\begin{array}{c}\text { SD } \\
\text { Sand } \\
(\%)\end{array}$ & $\begin{array}{c}\text { SD } \\
\text { Sean }\end{array}$ \\
\hline$<25$ & 29.74 & 12.16 & 5.35 & 3.16 & 23.72 & 15.56 & 28.21 & 10.49 & 47.88 & 4.36 & 23.91 & 11.78 \\
$25-35$ & 27.60 & 19.77 & 4.51 & 3.36 & 33.98 & 9.13 & 24.38 & 3.90 & 42.53 & 6.71 & 33.09 & 8.60 \\
$>35$ & 36.27 & 16.15 & 6.19 & 2.68 & 15.63 & 27.24 & 28.04 & 7.93 & 49.34 & 6.67 & 22.62 & 7.72 \\
\hline
\end{tabular}

Table 14b. Relation of vegetation coverage and bank characteristics.

\begin{tabular}{|c|c|c|c|c|c|c|c|c|c|c|}
\hline $\begin{array}{c}\text { Vegetation } \\
(\%)\end{array}$ & $\begin{array}{c}\text { Mean } \\
\text { Bank } \\
\text { Height } \\
\text { (m) }\end{array}$ & SD & $\begin{array}{c}\text { Mean } \\
\text { Bank } \\
\text { Angle } \\
\text { (Degrees) }\end{array}$ & SD & $\begin{array}{c}\text { Mean K } \\
\text { Factor }\end{array}$ & SD & $\begin{array}{c}\text { Mean LS } \\
\text { Factor }\end{array}$ & SD & $\begin{array}{l}\text { Mean } \\
\text { BEHI } \\
\text { Rating }\end{array}$ & SD \\
\hline$<25$ & 3.4 & 1.80 & 46.67 & 9.18 & 23.00 & 0.02 & 5.27 & 2.95 & 37.20 & 5.25 \\
\hline $25-35$ & 3.24 & 2.43 & 56.22 & 9.96 & 23.00 & 0.01 & 6.50 & 2.34 & 35.90 & 3.15 \\
\hline
\end{tabular}

Table 14c. Relation of vegetation coverage and morphological variables.

\begin{tabular}{ccccccccccc}
\hline $\begin{array}{c}\text { Vegetation } \\
(\%)\end{array}$ & $\begin{array}{c}\text { Mean } \\
\text { ER } \\
(\mathrm{m} / \mathrm{m})\end{array}$ & SD & $\begin{array}{c}\text { Mean } \\
\text { W/D } \\
\text { Ratio }\end{array}$ & SD & $\begin{array}{c}\text { Mean } \\
\text { Sinuosity } \\
(\mathrm{m} / \mathrm{m})\end{array}$ & SD & $\begin{array}{c}\text { Mean } \\
\text { D84 } \\
(\mathrm{mm})\end{array}$ & $\begin{array}{c}\text { Mean } \\
\text { Bankfull } \\
\text { Width } \\
(\mathrm{m})\end{array}$ & $\begin{array}{c}\text { SD } \\
\text { SD }\end{array}$ \\
\hline$<25$ & 1.72 & 1.08 & 25.64 & 23.22 & 1.36 & 0.48 & 113.78 & 35.62 & 3.29 & 2.81 \\
$25-35$ & 1.62 & 0.48 & 28.89 & 17.10 & 1.23 & 0.17 & 96.22 & 48.30 & 3.23 & 1.60 \\
$>35$ & 1.60 & 0.34 & 41.45 & 31.03 & 1.00 & 0.37 & 55.00 & 52.37 & 3.65 & 1.59 \\
\hline
\end{tabular}




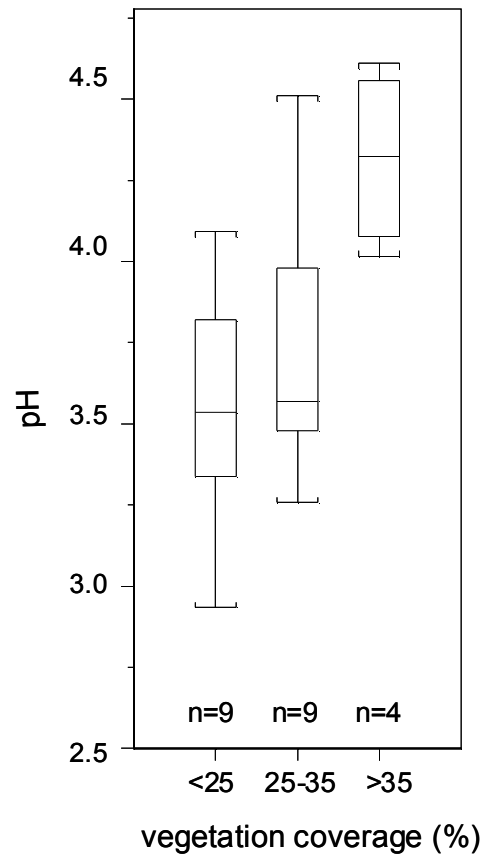

(a)

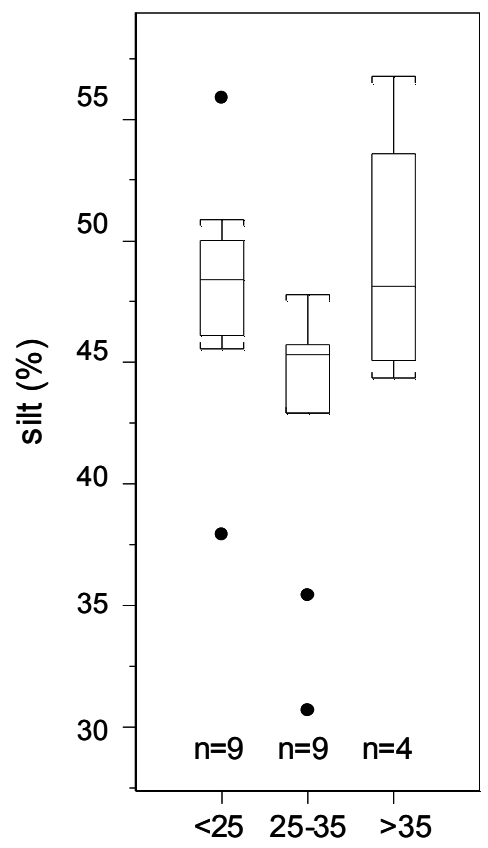

vegetation coverage (\%)

$(n)$

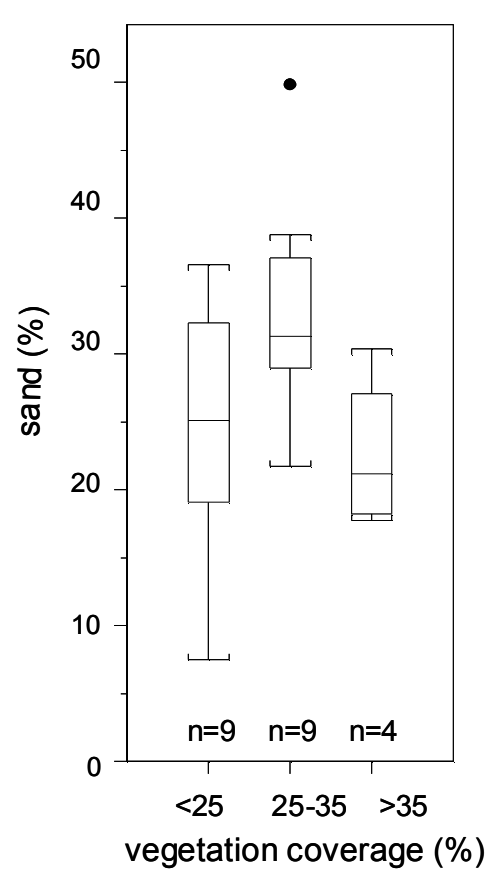

(b)

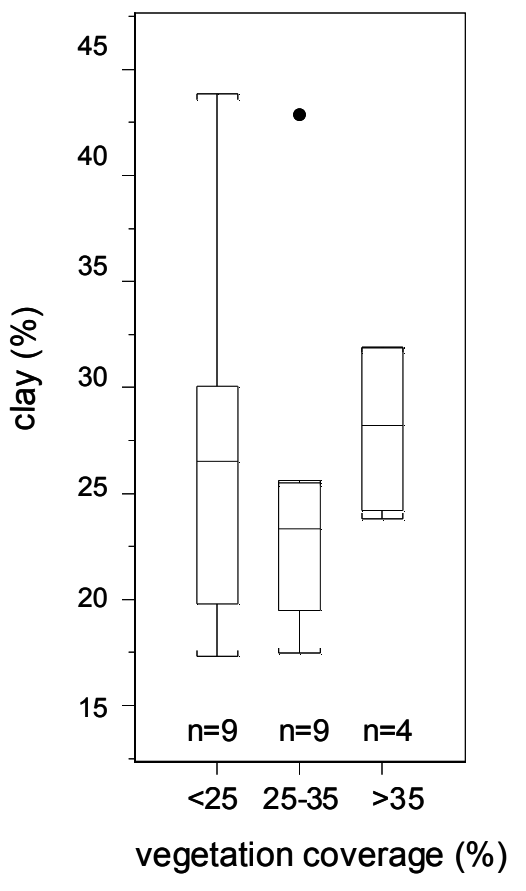

(d)

FIGURE 9. Comparison of $\mathrm{pH}$ (a), sand content (b), silt content (c), and clay content (d) as a function of percentage of vegetation coverage. 


\subsection{MoRPhOlOGiCAL RELATIONSHIPS}

The major morphological variables measured include channel gradient, entrenchement ratio, and width-depth ratio. Natural breaks in data were used to differentiate reaches with dissimilar morphological characteristics. Data from reaches with similar characteristics were combined and used to define relationships among morphological variables and between morphological and external variables.

\subsubsection{Channel Gradient}

The following categories were established for channel gradient; $<4 \%$ for gently sloping, 4 to $6 \%$ for moderately sloping, and $>6 \%$ for steep channels. Relationships among channel gradient and morphological variables are shown in Table 15a. Although trends were present relating mean values for morphological variables to channel gradient, large standard deviations and box and whisker plots showed wide, overlapping data distributions (Table 15a and Figure 10a).

Table $15 \mathrm{~b}$ shows relationships between gradient and channel bed features. Higher D84 and D50 particle sizes were generally found on steeper gradients (Figures 10b-c). Associations were found relating mean streambank characteristic values to gradient, however, standard deviation values showed large data distributions (Table 15c).

In stable stream systems, steeper gradients occur at upstream regions and level out progressively downstream generating a convex profile if substrate geology is uniform (Ritter et al., 2002). The instability of streams in the study area was apparent in the gradient variability shown in the longitudinal profiles (Figures 11a-c). Although some resemblance to the convex form may be observed, longitudinal profiles for these three streams were relatively irregular. Knickpoints, short, oversteepened segments of the 
Table 15a. Relationship of gradient and channel morphology.

\begin{tabular}{ccccccccc}
\hline Slope & $\begin{array}{c}\text { Mean } \\
\text { W/D } \\
\text { Ratio } \\
(\mathrm{mm})\end{array}$ & SD & $\begin{array}{c}\text { Mean } \\
\text { ER } \\
(\mathrm{mm})\end{array}$ & SD & $\begin{array}{c}\text { Mean } \\
\text { Sinuosity } \\
(\mathrm{m} / \mathrm{m})\end{array}$ & SD & $\begin{array}{c}\text { Mean } \\
\text { Bankfull } \\
\text { Width } \\
(\mathrm{m})\end{array}$ & SD \\
\hline$<4$ & 39.10 & 30.30 & 1.91 & 0.81 & 1.09 & 0.34 & 3.46 & 2.21 \\
$4-6$ & 34.24 & 21.16 & 1.68 & 0.43 & 1.22 & 0.14 & 4.29 & 2.88 \\
$>6$ & 19.18 & 12.68 & 1.42 & 0.48 & 1.35 & 0.40 & 3.65 & 1.77 \\
\hline
\end{tabular}

Table 15b. Relationship of gradient and channel bed characteristics.

\begin{tabular}{ccccccccc}
\hline Slope & $\begin{array}{c}\text { Mean } \\
\begin{array}{c}\text { Pool/Riffle } \\
\text { Ratio } \\
(\mathrm{m} / \mathrm{m})\end{array}\end{array}$ & SD & $\begin{array}{c}\text { Mean } \\
\text { D84 } \\
(\mathrm{mm})\end{array}$ & SD & $\begin{array}{c}\text { Mean } \\
\text { D50 } \\
(\mathrm{mm})\end{array}$ & SD & $\begin{array}{c}\text { Mean } \\
\text { w }(1.5 \mathrm{yrs}) \\
\mathrm{kg} 3 / \mathrm{m}\end{array}$ & SD \\
\hline$<4$ & 0.36 & 0.21 & 63.50 & 22.88 & 16.36 & 6.89 & 0.07 & 0.05 \\
$4-6$ & 0.35 & 0.21 & 82.20 & 43.40 & 19.30 & 11.47 & 0.15 & 0.19 \\
$>6$ & 0.23 & 0.29 & 132.33 & 36.23 & 30.43 & 15.42 & 0.13 & 0.11 \\
\hline
\end{tabular}

Table 15c. Relationship of gradient and streambank characteristics.

\begin{tabular}{ccccccc}
\hline Slope & $\begin{array}{c}\text { Mean } \\
\text { Bank } \\
\text { Height }(\mathrm{m})\end{array}$ & SD & $\begin{array}{c}\text { Mean } \\
\text { BEHI } \\
\text { Rating }\end{array}$ & SD & $\begin{array}{c}\text { Mean } \\
\text { LS } \\
\text { Factor }\end{array}$ & SD \\
\hline$<4$ & 2.05 & 1.61 & 31.99 & 6.73 & 3.91 & 2.56 \\
$4-6$ & 2.54 & 0.89 & 35.94 & 7.00 & 4.62 & 3.26 \\
$>6$ & 3.92 & 2.49 & 36.44 & 4.64 & 7.06 & 2.45 \\
\hline
\end{tabular}




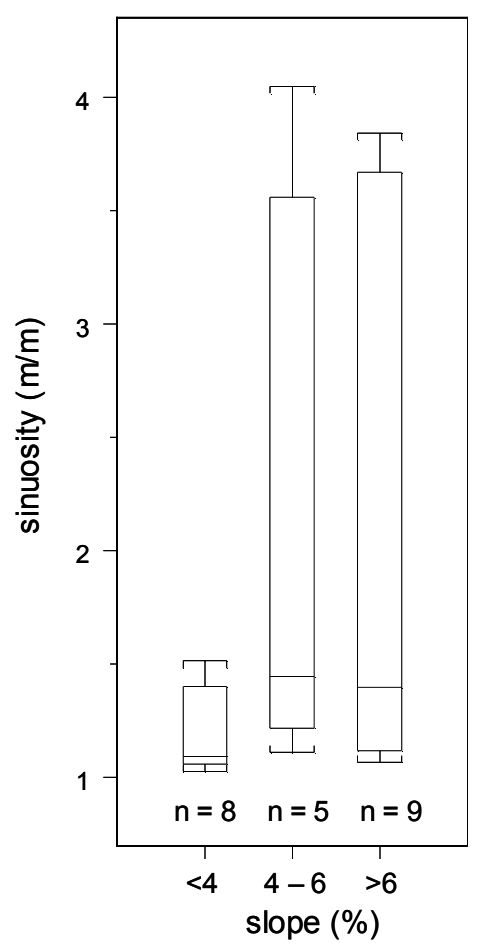

(a)

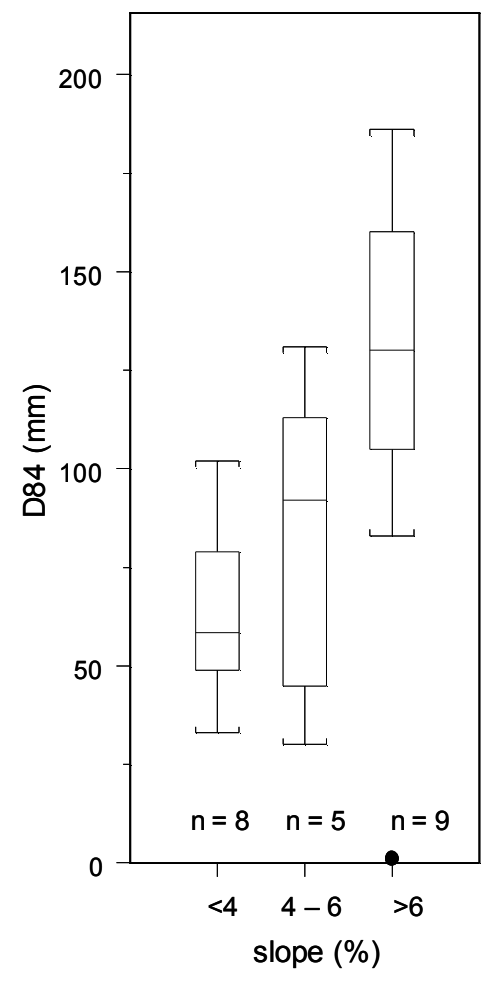

(c)

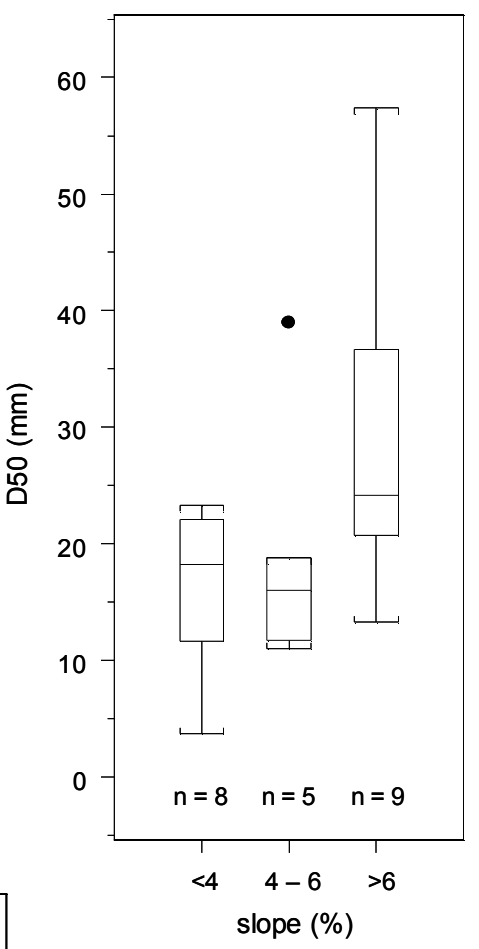

(b)

FIGURE 10. Comparison of sinuosity (a), D50 particle size (b), and D84 particle size as a function of channel gradient. 


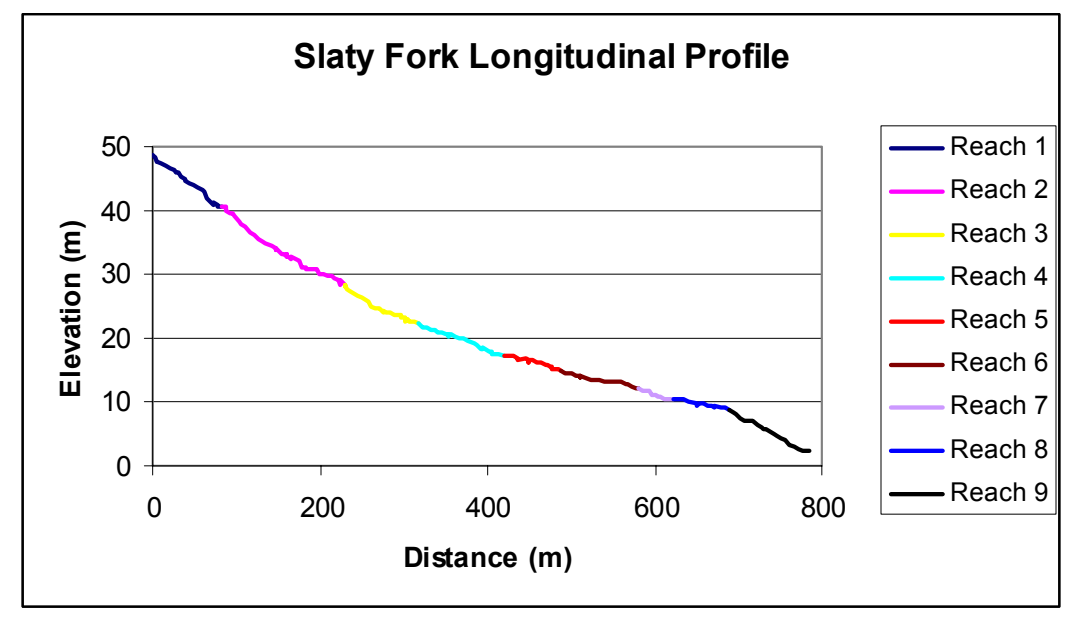

(a)

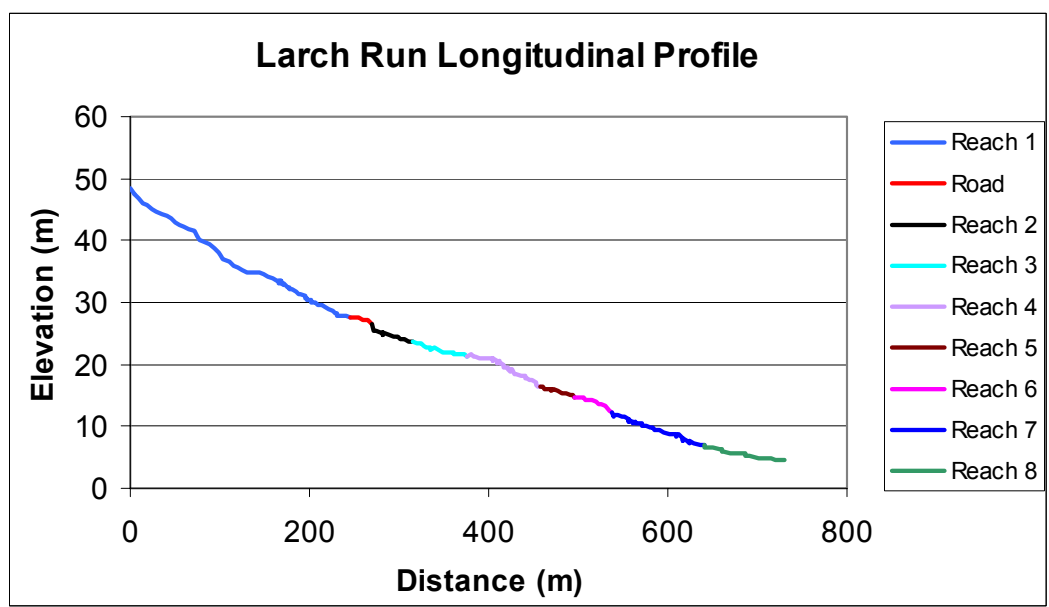

(b)

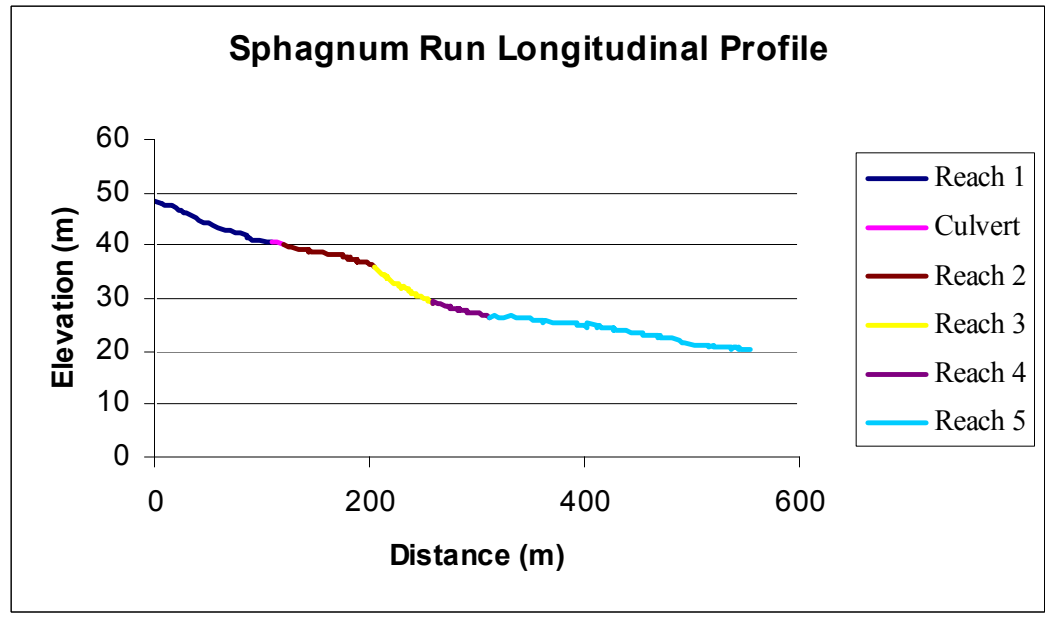

(c)

Figure 11. Comparison of elevation as a function of distance for Slaty Fork (a), Larch Run (b), and Sphagnum Run (c). 
longitudinal profile, occurred in all three profiles. Knickpoints occur when channel bed composition changes from resistant materials to softer materials. Knickpoints may indicate that channels are actively readjusting. Bed materials in this study were soft, which supports the assumption that the channels are actively readjusting. Knickpoints occurred between reaches six and seven and eight and nine of Slaty Fork, three and four and six and seven of Larch Run, and two and three of Sphagnum Run. The position of these irregularly spaced, steep slopes permits a wide variety of channel morphology to occur throughout the entire channel. Steep gradients occurred in downstream reaches as well as upstream reaches.

\subsubsection{Entrenchment Ratio}

Entrenchment ratio classes developed by Rosgen (1994) were used to describe the degree of incision for reaches. The classes used were as follows; entrenched channels $(<$ 1.4), moderately entrenched channels (1.4-2.2), and slightly entrenched channels $(>2.2)$. Entrenched channels $(<1.4)$ were less sinuous and had banks with higher rock fragment content than moderately and slightly entrenched channels (Table 16a-b).

Soil particle sizes, channel bed characteristics, and streambank characteristics had little differences when correlated to entrenchment classes (Tables 17a-b).

\subsubsection{Width to Depth Ratio}

The following groups were established for width-depth ratio based on Rosgen's (1994) Classification system; narrow channels $(<12)$, moderately wide channels (12-40), and wide channels $(>40)$. Narrow channels $(<12)$ occurred on steeper gradients, had lower pool to riffle ratios, higher banks, higher rock fragment percentages, and lower vegetation coverage when compared to wide channels $(>40)$ (Tables 18a-c). As channels 
Table 16a. Relationship of entrenchment ratio and channel morphology.

\begin{tabular}{|c|c|c|c|c|c|c|c|c|}
\hline $\begin{array}{c}\text { ER } \\
(\mathrm{m} / \mathrm{m})\end{array}$ & $\begin{array}{c}\text { Mean } \\
\text { Slope } \\
(\%)\end{array}$ & SD & $\begin{array}{l}\text { Mean } \\
\text { W/D } \\
\text { Ratio } \\
(\mathrm{mm})\end{array}$ & SD & $\begin{array}{c}\text { Mean } \\
\text { Sinuosity } \\
(\mathrm{m} / \mathrm{m})\end{array}$ & SD & $\begin{array}{l}\text { Mean } \\
\text { Bankfull } \\
\text { Width } \\
\text { (m) }\end{array}$ & SD \\
\hline$<1.4$ & 4.94 & 1.83 & 29.42 & 13.35 & 1.10 & 0.02 & 3.60 & 1.83 \\
\hline $1.4-2$ & 6.60 & 2.85 & 31.04 & 28.56 & 1.27 & 0.43 & 3.09 & 2.33 \\
\hline$>2$ & 3.50 & 0.92 & 26.90 & 5.47 & 1.29 & 0.25 & 3.67 & 2.28 \\
\hline
\end{tabular}

Table 16b. Relations of entrenchment ratio and external variables.

\begin{tabular}{ccccccccc}
\hline $\begin{array}{c}\text { ER } \\
(\mathrm{m} / \mathrm{m})\end{array}$ & $\begin{array}{c}\text { Mean } \\
\text { Aggregate } \\
\text { Stability (\%) }\end{array}$ & SD & $\begin{array}{c}\text { Mean } \\
\text { Organic } \\
\text { Matter (\%) }\end{array}$ & $\begin{array}{c}\text { Mean } \\
\text { SD Vegetation } \\
(\%)\end{array}$ & SD & $\begin{array}{c}\text { Mean Rock } \\
\text { Fragments } \\
(\%)\end{array}$ & SD \\
\hline$<1.4$ & 20.28 & 4.22 & 3.70 & 1.44 & 26.70 & 18.84 & 35.50 & 12.42 \\
$1.4-2$ & 31.62 & 13.63 & 5.79 & 3.51 & 28.79 & 20.52 & 24.41 & 20.95 \\
$>2$ & 37.17 & 28.75 & 4.92 & 2.34 & 33.13 & 31.32 & 21.75 & 10.52 \\
\hline
\end{tabular}


Table 17a. Relationship of entrenchment ratio and channel bed features.

\begin{tabular}{ccccccccc}
$\begin{array}{c}\text { ER } \\
(\mathrm{m} / \mathrm{m})\end{array}$ & $\begin{array}{c}\text { Mean } \\
\text { Pool/Riffle } \\
\begin{array}{c}\text { Ratio } \\
(\mathrm{m} / \mathrm{m})\end{array}\end{array}$ & SD & $\begin{array}{c}\text { Mean } \\
\text { D84 } \\
(\mathrm{mm})\end{array}$ & SD & $\begin{array}{c}\text { Mean } \\
\text { D50 } \\
(\mathrm{mm})\end{array}$ & $\mathrm{SD}$ & $\begin{array}{c}\text { Mean } \\
\mathrm{w}(1.5 \mathrm{yr}) \\
\mathrm{kg} / \mathrm{m}\end{array}$ & $\mathrm{SD}$ \\
\hline$<1.4$ & 0.23 & 0.15 & 92.00 & 42.60 & 23.78 & 8.47 & 0.13 & 0.13 \\
$1.4-2$ & 0.32 & 0.30 & 105.67 & 48.36 & 23.58 & 16.41 & 0.12 & 0.13 \\
$>2$ & 0.37 & 0.19 & 72.50 & 31.64 & 18.90 & 5.00 & 0.07 & 0.03 \\
\hline
\end{tabular}

Table 17b. Relation of entrenchment ratio and soil texture

\begin{tabular}{ccccccc}
$\begin{array}{c}\text { ER } \\
(\mathrm{m} / \mathrm{m})\end{array}$ & $\begin{array}{c}\text { Mean } \\
\text { Clay } \\
(\%)\end{array}$ & SD & $\begin{array}{c}\text { Mean } \\
\text { Silt } \\
(\%)\end{array}$ & SD & $\begin{array}{c}\text { Mean } \\
\text { Sand } \\
(\%)\end{array}$ & SD \\
\hline$<1.4$ & 27.50 & 9.88 & 42.76 & 6.84 & 29.74 & 14.67 \\
$1.4-2$ & 26.17 & 8.69 & 46.64 & 4.79 & 27.19 & 8.52 \\
$>2$ & 26.94 & 3.46 & 47.73 & 8.02 & 25.33 & 7.49 \\
\hline
\end{tabular}


Table 18a. Relation of width-depth ratio to morphological variables.

\begin{tabular}{ccccccccc}
\hline $\begin{array}{c}\text { Width to } \\
\begin{array}{c}\text { Depth } \\
\text { Ratio }\end{array}\end{array}$ & $\begin{array}{c}\text { Mean } \\
\text { Slope } \\
(\%)\end{array}$ & SD & $\begin{array}{c}\text { Mean } \\
\text { ER } \\
(\mathrm{mm})\end{array}$ & SD & $\begin{array}{c}\text { Mean } \\
\text { Sinuosity } \\
(\mathrm{m} / \mathrm{m})\end{array}$ & SD & $\begin{array}{c}\text { Mean } \\
\text { Pool/Riffle } \\
\text { Ratio } \\
(\mathrm{m} / \mathrm{m})\end{array}$ & SD \\
\hline$<12$ & 7.42 & 1.06 & 1.10 & 0.70 & 1.17 & 0.43 & 0.15 & 0.13 \\
$12-40$ & 5.55 & 2.28 & 1.86 & 0.61 & 1.32 & 0.20 & 0.33 & 0.25 \\
$>40$ & 3.53 & 1.87 & 1.37 & 0.20 & 1.00 & 0.37 & 0.43 & 0.29 \\
\hline
\end{tabular}

Table 18b. Relation of width-depth ratio to streambank characteristics.

\begin{tabular}{ccccccc}
\hline $\begin{array}{c}\text { Width to } \\
\text { Depth } \\
\text { Ratio }\end{array}$ & $\begin{array}{c}\text { Mean } \\
\text { Bank } \\
\text { Height }(\mathrm{m})\end{array}$ & SD & $\begin{array}{c}\text { Mean } \\
\text { BEHI } \\
\text { Rating }\end{array}$ & SD & $\begin{array}{c}\text { Mean } \\
\text { LS } \\
\text { Factor }\end{array}$ & SD \\
\hline$<12$ & 5.23 & 1.12 & 40.87 & 5.00 & 8.84 & 2.30 \\
$12-40$ & 2.71 & 1.37 & 34.19 & 4.68 & 5.40 & 2.61 \\
$>40$ & 1.40 & 1.97 & 30.87 & 9.60 & 2.04 & 3.70 \\
\hline
\end{tabular}

Table 18c. Relation of width-depth ratio and external variables.

\begin{tabular}{ccccccccc} 
W/D & $\begin{array}{c}\text { Mean } \\
\text { Aggregate } \\
\text { ratio } \\
\text { Stability } \\
(\%)\end{array}$ & SD & $\begin{array}{c}\text { Mean } \\
\text { Organic } \\
\text { Matter } \\
(\%)\end{array}$ & SD & $\begin{array}{c}\text { Mean } \\
\text { Vegetation } \\
(\%)\end{array}$ & SD & $\begin{array}{c}\text { Mean Rock } \\
\text { Fragments } \\
(\%)\end{array}$ & SD \\
\hline$<12$ & 26.59 & 11.70 & 3,68 & 2.15 & 13.44 & 18.10 & 35.28 & 16.46 \\
$12-40$ & 31.11 & 17.98 & 5.38 & 2.99 & 29.53 & 17.18 & 27.13 & 19.03 \\
$>40$ & 27.32 & 10.06 & 5.44 & 3.54 & 38.75 & 33.26 & 18.00 & 9.63 \\
\hline
\end{tabular}

Table 18d. Relation of width-depth ratio and soil particle sizes.

\begin{tabular}{ccccccc}
$\begin{array}{c}\text { W/D } \\
\text { ratio }\end{array}$ & $\begin{array}{c}\text { Mean } \\
\text { Clay } \\
(\%)\end{array}$ & SD & $\begin{array}{c}\text { Mean } \\
\text { Silt } \\
(\%)\end{array}$ & SD & $\begin{array}{c}\text { Mean } \\
\text { Sand } \\
(\%)\end{array}$ & SD \\
\hline$<12$ & 31.06 & 10.12 & 46.18 & 3.58 & 22.14 & 8.80 \\
$12-40$ & 24.44 & 6.70 & 45.32 & 6.65 & 30.24 & 9.65 \\
$>40$ & 33.72 & 9.15 & 36.81 & 2.14 & 17.76 & 10.60 \\
\hline
\end{tabular}


became wider, the BEHI rating and LS factor decreased indicating that these channels were less sensitive to erosion (Table 18b). Schumm (1960) proposed that channel shape, defined by the width-depth ratio, is related to soil texture. Streambanks with high silt and clay percentages produce narrow, deep channels, while banks consisting of coarse grained soils produce wide, shallow channels. Results from this study did not correlate with Schumm's findings. There were no strong relationships between soil particle sizes and width-depth ratio in this study (Table 18d).

\subsubsection{Similar Stream Reaches}

To quantify if the streams were developing similarly, reaches were analyzed based on visual observations and morphological variables. Similar reaches were initially established based on dominant channel materials. Additionally, further classification of aggrading reaches was based on morphological variables. Six classifications were created and defined as: steep-cobble, transition-aggrading, wide-aggrading, transitionbedrock, bedrock, and wetland. Tables 19-23 show similar channel types and comparisons to external controls and morphological controls described in detail below.

The uppermost reaches of all three streams and reach four of both Larch Run and Sphagnum Run were classified as steep-cobble reaches (Table 24). Gravel and cobble were the dominant channel materials for this group. These reaches occurred on steep slopes, were moderately entrenched, sinuous, had high organic matter percentages, and relatively low width-depth ratios (Tables 20 and 21). Steep cobble reaches had high pool-riffle ratios, high D84 and D50 particle sizes, and moderate stream power when compared to other stream reach categories. No relationship with bankfull width and bank height was found among these reaches. 
Slaty Fork reaches six and eight and Larch run reaches two and seven were classified as transition aggrading reaches (Table 25). Transition aggrading reaches occurred on gentle to moderate slopes, were slightly entrenched, sinuous, and dominant channel materials were gravel (Table 21). Additionally, high banks, bankfull widths around three meters, high organic matter content, and high rock fragment percentages characterized these reaches (Tables 20 and 23). Further, these channels had low poolriffle ratios, high D50 particle sizes, and moderate stream power values when compared to the other reach categories (Table 22). This class of reaches served as transitional areas from steep to gentle aggrading slopes, or aggrading to bedrock reaches. Often, abrupt changes from aggrading to bedrock channels were noted.

Wide aggrading reaches consisted of Slaty Fork reach five and Larch Run reaches three and eight (Table 26). Reaches generally occurred on gentle slopes, had high widthdepth ratios, wide channels, and low banks (Tables 21 and 23). Dominant channel materials were gravel, and at low flows these streams were braided. Wide aggrading reaches had the highest pool-riffle ratios, low D84 particle sizes, and lowest stream power values when compared to other stream reach classifications (Table 22). Low aggregate stabilities and high sand percentages also characterize these reaches (Table 19). All aggrading reach types had high silt and sand percentages and lower clay percentages (Table 19).

Slaty Fork reach four and Larch Run reach five comprised transition bedrock reaches (Table 27). These reaches occurred on moderate gradients, had low sinuosities, and were entrenched to moderately entrenched (Table 21). Smooth bedrock and channel sediments were both exposed throughout these channels. Characteristics of aggrading 
and bedrock reaches occurred in these reaches. Dominant channel materials were gravel and/or bedrock. Transitional bedrock reaches had low pool-riffle ratios, high D84 and low D50 particle sizes, and the highest stream power values when compared to other reaches (Table 22).

Bedrock reaches consisted of Slaty Fork reaches three, seven, and nine and Larch Run reach six (Table 28). Reaches occurred on steep slopes comprised of bedrock. Bedrock channels were generally entrenched with low sinuosity, low width-depth ratios, high banks, and narrow bankfull widths (Tables 21 and 23). These reaches had the lowest pool-riffle ratios, high D84 and D50 particle sizes, and moderate stream power values when compared to other reaches (Table 22). Both transitional bedrock and bedrock reaches had high silt and clay percentages and lower sand percentages (Table 19).

Sphagnum Run reaches two and five had wetland characteristics, thus were classified as wetland reaches (Table 29). These reaches had low sinuosities, low banks, high pool-riffle ratios, low D84 and D50 particle sizes, and moderate stream power values when compared to other reaches (Tables 21, 22, and 23). Wetland reaches had the highest silt percentages, lowest sand percentages, high organic matter content, and the highest vegetation coverage (Tables 19 and 20). The two wetland reaches differ greatly in slope, entrenchment ratio, and width-depth ratio.

Slaty Fork reach two and Sphagnum Run reach three were significantly different from all other reaches, and thus not associated with any other reaches (Table 30). Slaty Fork reach two occurred on a steep slope and had banks as high as $9 \mathrm{~m}$. The high banks were unvegetated, covered with gulleys, and contributed a significant amount of sediment 
to the channel. The cross section for this reach was taken below the wide aggrading portion because no bankfull indicators could be identified on the sediment-laden section. This cross section was selected based on field indicators, later found not to be representative of this reach.

Sphagnum Run reach three had the steepest gradient of any reach and was comprised of step-pools. There were no other step-pool dominated reaches in this study. 
Table 19. Soil Properties of Similar Stream Reaches.

\begin{tabular}{ccccccc}
\hline Channel Type & $\begin{array}{c}\text { Mean } \\
\text { Clay } \\
(\%)\end{array}$ & SD & $\begin{array}{c}\text { Mean } \\
\text { Silt } \\
(\%)\end{array}$ & SD & $\begin{array}{c}\text { Mean } \\
\text { Sand } \\
(\%)\end{array}$ & SD \\
\hline Steep Aggrading & 22.15 & 4.09 & 46.65 & 7.65 & 31.20 & 6.33 \\
Transition Aggrading & 24.12 & 4.28 & 36.61 & 2.58 & 28.49 & 6.69 \\
Wide Aggrading & 24.92 & 5.16 & 42.45 & 7.89 & 36.72 & 11.54 \\
Transition Bedrock & 30.66 & 18.65 & 47.05 & 2.27 & 22.29 & 20.92 \\
Bedrock & 35.26 & 9.34 & 43.24 & 5.36 & 21.49 & 8.70 \\
Wetland & 28.21 & 5.11 & 53.59 & 4.48 & 18.20 & 0.63 \\
\hline
\end{tabular}

Table 20. External Properties of Similar Stream Reaches.

\begin{tabular}{ccccccccc}
\hline & $\begin{array}{c}\text { Mean } \\
\text { Aggregate } \\
\text { Stability } \\
(\%)\end{array}$ & SD & $\begin{array}{c}\text { Mean } \\
\text { Organic } \\
\text { Matter } \\
(\%)\end{array}$ & SD & $\begin{array}{c}\text { Mean Rock } \\
\text { Fragments } \\
(\%)\end{array}$ & SD & $\begin{array}{c}\text { Mean } \\
\text { Vegetation } \\
(\%)\end{array}$ & SD \\
\hline Steep Aggrading & 40.07 & 12.56 & 6.08 & 0.75 & 12.90 & 6.00 & 22.00 & 15.47 \\
Transition Aggrading & 39.31 & 26.29 & 4.53 & 1.57 & 27.13 & 10.27 & 24.00 & 4.55 \\
Wide Aggrading & 13.70 & 2.81 & 3.68 & 1.16 & 24.50 & 16.22 & 20.00 & 12.99 \\
Transition Bedrock & 26.74 & 0.48 & 3.05 & 1.59 & 22.25 & 21.57 & 18.75 & 8.83 \\
Bedrock & 19.47 & 6.36 & 3.18 & 1.67 & 45.63 & 29.47 & 29.38 & 21.54 \\
Wetland & 33.15 & 10.77 & 4.32 & 2.38 & 21.25 & 8.84 & 82.50 & 7.07 \\
\hline
\end{tabular}


Table 21. Morphologic Characteristics of Similar Stream Reaches.

\begin{tabular}{|c|c|c|c|c|c|c|c|c|c|c|}
\hline Channel Type & $\begin{array}{c}\text { Mean } \\
\text { Slope } \\
(\%)\end{array}$ & SD & $\begin{array}{l}\text { Mean } \\
\text { W/D } \\
\text { Ratio } \\
(\mathrm{m} / \mathrm{m})\end{array}$ & SD & $\begin{array}{c}\text { Mean } \\
\text { ER } \\
(\mathrm{m} / \mathrm{m})\end{array}$ & SD & $\begin{array}{l}\text { Mean } \\
\text { Sinuosity } \\
(\mathrm{m} / \mathrm{m})\end{array}$ & SD & $\begin{array}{c}\text { Mean } \\
\text { Bankfull } \\
(\mathrm{m})\end{array}$ & SD \\
\hline Steep Aggrading & 7.29 & 1.70 & 18.74 & 1.62 & 1.62 & 0.23 & 1.47 & 0.51 & 2.64 & 1.76 \\
\hline Transition Aggrading & 3.76 & 1.17 & 26.65 & 1.90 & 1.9 & 0.56 & 1.28 & 0.22 & 2.98 & 0.35 \\
\hline Wide Aggrading & 3.36 & 0.66 & 44.13 & 2.1 & 2.1 & 1.30 & 1.20 & 0.27 & 5.80 & 1.84 \\
\hline Transition Bedrock & 4.16 & 0.41 & 44.00 & 1.45 & 1.45 & 0.21 & 1.17 & 0.07 & 5.49 & 5.10 \\
\hline Bedrock & 6.09 & 1.43 & 21.38 & 1.13 & 1.13 & 0.59 & 1.16 & 0.16 & 2.23 & 0.99 \\
\hline Wetland & 3.56 & 1.54 & 63.65 & 1.85 & 1.85 & 0.64 & 0.74 & 0.49 & 4.21 & 2.20 \\
\hline
\end{tabular}

Table 22. Channel Characteristics of Similar Stream Reaches.

\begin{tabular}{ccccccccc}
\hline Channel Type & $\begin{array}{c}\text { Mean } \\
\text { Pool/Riffle } \\
\text { Ratio } \\
(\mathrm{m} / \mathrm{m})\end{array}$ & SD & $\begin{array}{c}\text { Mean } \\
\text { D84 } \\
(\mathrm{mm})\end{array}$ & SD & $\begin{array}{c}\text { Mean } \\
\text { D50 } \\
(\mathrm{mm})\end{array}$ & SD & $\begin{array}{c}\text { Mean } \\
\text { ( }(1.5 \mathrm{yr})\end{array}$ & SD \\
$(\mathrm{kg} 3 \mathrm{~m} / \mathrm{s})$ & \\
\hline Steep Aggrading & $1: 2.1$ & 0.40 & 117.6 & 35.05 & 24.74 & 18.57 & 0.65 & 0.43 \\
Transition Aggrading & $1: 4.5$ & 0.11 & 82 & 31.23 & 22.7 & 11.75 & 0.49 & 0.05 \\
Wide Aggrading & $1: 1.8$ & 0.12 & 63 & 23.44 & 19.37 & 6.64 & 0.90 & 0.54 \\
Transition Bedrock & $1: 3.7$ & 0.09 & 97 & 48.10 & 11.25 & 10.68 & 0.82 & 0.11 \\
Bedrock & $1: 8.3$ & 0.07 & 103.5 & 57.07 & 24.10 & 7.76 & 1.85 & 1.55 \\
Wetland & $1: 2.1$ & & 41 & 15.56 & 11.65 & 0.07 & 0.42 & 0.27 \\
\hline
\end{tabular}

Table 23. Streambank Characteristics of Similar Stream Reaches.

\begin{tabular}{cccccccccccc}
\hline Channel Type & $\begin{array}{c}\text { Mean } \\
\text { Bank } \\
\text { Height } \\
(\mathrm{m})\end{array}$ & SD & $\begin{array}{c}\text { Mean } \\
\text { Bank } \\
\text { Angle }\end{array}$ & SD & $\begin{array}{c}\text { Mean } \\
\text { BEHI } \\
\text { Rating }\end{array}$ & SD & $\begin{array}{c}\text { Mean } \\
\text { LS } \\
\text { Factor }\end{array}$ & SD & $\begin{array}{c}\text { Mean } \\
\text { Kactor }\end{array}$ & SD \\
\hline Steep Aggrading & 2.98 & 2.43 & 56.60 & 6.88 & 37.30 & 4.48 & 6.10 & 2.61 & 0.24 & 0.01 \\
Transition Aggrading & 3.95 & 0.17 & 53.75 & 5.38 & 37.88 & 4.24 & 6.79 & 1.57 & 0.23 & 0.01 \\
Wide Aggrading & 1.47 & 1.25 & 45.33 & 1.25 & 34.17 & 5.54 & 3.14 & 1.95 & 0.24 & 0.01 \\
Transition Bedrock & 1.80 & 1.7 & 47.00 & 12.73 & 36.05 & 1.34 & 3.31 & 0.50 & 0.23 & 0.04 \\
Bedrock & 3.50 & 0.99 & 57.75 & 16.07 & 35.18 & 6.00 & 7.78 & 1.60 & 0.21 & 0.01 \\
Wetland & 0.25 & 0.07 & 1.50 & 0.07 & 21.15 & 4.88 & 0.04 & 0.03 & 0.22 & 0.002 \\
\hline
\end{tabular}


Table 24. Stream reaches characterized as steep cobble.

\begin{tabular}{cccccccc}
\hline $\begin{array}{c}\text { Similar } \\
\text { Reaches }\end{array}$ & $\begin{array}{c}\text { Mean } \\
\text { Slope } \\
(\%)\end{array}$ & $\begin{array}{c}\text { Mean } \\
\text { ER } \\
(\mathrm{m} / \mathrm{m})\end{array}$ & $\begin{array}{c}\text { Mean } \\
\text { Width/Depth } \\
\text { Ratio } \\
(\mathrm{m} / \mathrm{m})\end{array}$ & $\begin{array}{c}\text { Mean } \\
\text { Sinuosity } \\
(\mathrm{m} / \mathrm{m})\end{array}$ & $\begin{array}{c}\text { Mean } \\
\text { Bankfull } \\
(\mathrm{m})\end{array}$ & $\begin{array}{c}\text { Mean } \\
\text { Bank } \\
\text { Height } \\
(\mathrm{m})\end{array}$ & $\begin{array}{c}\text { Mean } \\
\text { Bank } \\
\text { Angle } \\
\text { (Degrees) }\end{array}$ \\
\hline SL:1 & 9.53 & 1.40 & 24.20 & 1.12 & 3.41 & 1.10 & 65.00 \\
L:1 & 8.48 & 1.60 & 18.70 & 2.33 & 3.05 & 1.50 & 53.00 \\
L:4 & 6.14 & 1.80 & 23.70 & 1.57 & 4.97 & 3.50 & 55.00 \\
S:1 & 6.91 & 1.40 & 11.70 & 1.12 & 1.10 & 7.00 & 62.00 \\
S:4 & 5.39 & 1.90 & 15.40 & 1.23 & 0.67 & 1.80 & 48.00 \\
\hline & * SL represents Slaty Fork & & & & \\
& * L represents Larch Run & & & & \\
& * S represents Sphagnum Run
\end{tabular}

Table 25. Stream reaches characterized as transition aggrading.

\begin{tabular}{cccccccc}
\hline $\begin{array}{c}\text { Similar } \\
\text { Reaches }\end{array}$ & $\begin{array}{c}\text { Mean } \\
\text { Slope } \\
(\%)\end{array}$ & $\begin{array}{c}\text { Mean } \\
\text { ER } \\
(\mathrm{m} / \mathrm{m})\end{array}$ & $\begin{array}{c}\text { Mean } \\
\text { Width/Depth } \\
\text { Ratio } \\
(\mathrm{m} / \mathrm{m})\end{array}$ & $\begin{array}{c}\text { Mean } \\
\text { Sinuosity } \\
(\mathrm{m} / \mathrm{m})\end{array}$ & $\begin{array}{c}\text { Mean } \\
\text { Bankfull } \\
(\mathrm{m})\end{array}$ & $\begin{array}{c}\text { Mean } \\
\text { Bank } \\
\text { Height } \\
(\mathrm{m})\end{array}$ & $\begin{array}{c}\text { Mean } \\
\text { Bank } \\
\text { Angle } \\
(\text { Degrees })\end{array}$ \\
\hline SL:6 & 2.9 & 2.40 & 31.30 & 1.49 & 3.20 & 4.00 & 53.00 \\
SL:8 & 2.63 & 2.30 & 18.90 & 1.07 & 2.47 & 4.10 & 48.00 \\
L:2 & 4.50 & 1.70 & 30.60 & 1.44 & 3.23 & 4.00 & 61.00 \\
L:7 & 5.00 & 1.20 & 25.80 & 1.11 & 3.02 & 3.70 & 53.00 \\
\hline
\end{tabular}

Table 26. Stream reaches characterized as wide aggrading.

\begin{tabular}{cccccccc}
\hline Similar & $\begin{array}{c}\text { Mean } \\
\text { Reaches } \\
(\%)\end{array}$ & $\begin{array}{c}\text { Mean } \\
\text { ER } \\
(\mathrm{m} / \mathrm{m})\end{array}$ & $\begin{array}{c}\text { Mean } \\
\text { Width/Depth } \\
\text { Ratio } \\
(\mathrm{m} / \mathrm{m})\end{array}$ & $\begin{array}{c}\text { Mean } \\
\text { Sinuosity } \\
(\mathrm{m} / \mathrm{m})\end{array}$ & $\begin{array}{c}\text { Mean } \\
\text { Bankfull } \\
(\mathrm{m})\end{array}$ & $\begin{array}{c}\text { Mean } \\
\text { Bank } \\
\text { Height } \\
(\mathrm{m})\end{array}$ & $\begin{array}{c}\text { Mean } \\
\text { Bank } \\
\text { Angle } \\
(\text { Degrees })\end{array}$ \\
\hline SL:5 & 3.80 & 3.60 & 28.60 & 1.51 & 6.37 & 0.60 & 38.00 \\
L:3 & 3.68 & 1.40 & 73.20 & 1.02 & 7.28 & 0.90 & 43.00 \\
L:8 & 2.60 & 1.30 & 30.60 & 1.06 & 3.75 & 2.90 & 49.00 \\
\hline
\end{tabular}


Table 27. Stream reaches characterized as transition bedrock.

\begin{tabular}{cccccccc}
\hline $\begin{array}{c}\text { Similar } \\
\text { Reaches }\end{array}$ & $\begin{array}{c}\text { Mean } \\
\text { Slope } \\
(\%)\end{array}$ & $\begin{array}{c}\text { Mean } \\
\text { ER } \\
(\mathrm{m} / \mathrm{m})\end{array}$ & $\begin{array}{c}\text { Mean } \\
\text { Width/Depth } \\
\text { Ratio } \\
(\mathrm{m} / \mathrm{m})\end{array}$ & $\begin{array}{c}\text { Mean } \\
\text { Sinuosity } \\
(\mathrm{m} / \mathrm{m})\end{array}$ & $\begin{array}{c}\text { Mean } \\
\text { Bankfull } \\
(\mathrm{m})\end{array}$ & $\begin{array}{c}\text { Mean } \\
\text { Bank } \\
\text { Height } \\
(\mathrm{m})\end{array}$ & $\begin{array}{c}\text { Mean } \\
\text { Bank } \\
\text { Angle } \\
(\text { Degrees })\end{array}$ \\
\hline SL:4 & 4.45 & 1.30 & 70.60 & 1.22 & 9.08 & 3.00 & 38.00 \\
L:5 & 3.87 & 1.60 & 17.40 & 1.12 & 1.89 & 0.60 & 56.00 \\
\hline
\end{tabular}

Table 28. Stream reaches characterized as bedrock.

\begin{tabular}{cccccccc}
\hline $\begin{array}{c}\text { Similar } \\
\text { Reaches }\end{array}$ & $\begin{array}{c}\text { Mean } \\
\text { Slope } \\
(\%)\end{array}$ & $\begin{array}{c}\text { Mean } \\
\text { ER } \\
(\mathrm{m} / \mathrm{m})\end{array}$ & $\begin{array}{c}\text { Mean } \\
\text { Width/Depth } \\
\text { Ratio } \\
(\mathrm{m} / \mathrm{m})\end{array}$ & $\begin{array}{c}\text { Mean } \\
\text { Sinuosity } \\
(\mathrm{m} / \mathrm{m})\end{array}$ & $\begin{array}{c}\text { Mean } \\
\text { Bankfull } \\
(\mathrm{m})\end{array}$ & $\begin{array}{c}\text { Mean } \\
\text { Bank } \\
\text { Height } \\
(\mathrm{m})\end{array}$ & $\begin{array}{c}\text { Mean } \\
\text { Bank } \\
\text { Angle } \\
(\text { Degrees })\end{array}$ \\
\hline SL:3 & 6.72 & 0.30 & 7.80 & 1.07 & 1.01 & 4.00 & 47.00 \\
SL:7 & 4.44 & 1.30 & 14.30 & 1.06 & 2.77 & 3.00 & 45.00 \\
SL:9 & 6.81 & 1.70 & 36.00 & 1.40 & 3.17 & 2.40 & 80.00 \\
L:6 & 6.89 & 1.20 & 27.40 & 1.10 & 1.98 & 4.60 & 59.00 \\
\hline
\end{tabular}

Table 29. Stream reaches characterized as wetland.

\begin{tabular}{cccccccc}
\hline Similar & $\begin{array}{c}\text { Mean } \\
\text { Reape } \\
(\%)\end{array}$ & $\begin{array}{c}\text { Mean } \\
\text { ER } \\
(\mathrm{m} / \mathrm{m})\end{array}$ & $\begin{array}{c}\text { Mean } \\
\text { Width/Depth } \\
\text { Ratio } \\
(\mathrm{m} / \mathrm{m})\end{array}$ & $\begin{array}{c}\text { Mean } \\
\text { Sinuosity } \\
(\mathrm{m} / \mathrm{m})\end{array}$ & $\begin{array}{c}\text { Mean } \\
\text { Bankfull } \\
(\mathrm{m})\end{array}$ & $\begin{array}{c}\text { Mean } \\
\text { Bank } \\
\text { Height } \\
(\mathrm{m})\end{array}$ & $\begin{array}{c}\text { Mean } \\
\text { Bank } \\
\text { Angle } \\
(\text { Degrees })\end{array}$ \\
\hline SR:2 & 4.50 & 2.30 & 28.80 & 1.08 & 2.65 & 0.20 & 2.00 \\
SR:5 & 2.47 & 1.40 & 98.50 & 0.40 & 5.76 & 0.30 & 1.00 \\
\hline
\end{tabular}

Table 30. Stream reaches deemed unclassified.

\begin{tabular}{ccccccc}
\hline Stream & $\begin{array}{c}\text { Mean Slope } \\
\text { Reach }\end{array}$ & $\begin{array}{c}\text { Mean } \\
\text { ER } \\
(\mathrm{m} / \mathrm{m})\end{array}$ & $\begin{array}{c}\text { Mean } \\
\text { Width/Depth } \\
\text { Ratio } \\
(\mathrm{m} / \mathrm{m})\end{array}$ & $\begin{array}{c}\text { Mean } \\
\text { Sinuosity } \\
(\mathrm{m} / \mathrm{m})\end{array}$ & $\begin{array}{c}\text { Mean } \\
\text { Bankfull } \\
(\mathrm{m})\end{array}$ & $\begin{array}{c}\text { Mean } \\
\text { Bank } \\
\text { Height } \\
(\mathrm{m})\end{array}$ \\
\hline SL:2 & 8.64 & 1.60 & 2.20 & 1.31 & 0.37 & 7.00 \\
SR:3 & 12.72 & 1.80 & 20.90 & 1.17 & 2.13 & 5.00 \\
\hline
\end{tabular}




\subsection{Statistical Analysis}

The cluster analysis of the reach data (Figure 12) produced two distinct clusters; Cluster A and Cluster B. The distance (greatest distance is least similarity) for Cluster A to Cluster B was 1.5. Cluster B was comprised of reaches only from Sphagnum Run, while the larger Cluster A contained reaches from both Slaty Fork and Larch Run, and none from Sphagnum Run. These results strengthen the argument that Sphagnum Run is unique from the two other streams in the study.

Sphagnum Run was largely differentiated by reach type (wetland and step-pool reaches). Reaches were unique to Sphagnum Run having high organic matter values, high vegetation percentages, an average higher width/depth ratio, and a lower sinuosity. Sphagnum Run appeared to be the most stable of the streams within the study with less reported bank failures and little evidence of aggradation within the channel.

\subsection{Future Channel Alterations}

Graded time is defined as adjustments a river might make to counterbalance changes in discharge and load that occur over a period of years to hundreds of years. The streams in this study have been adjusting to counteract mining disturbances for the past 40 years.

Streams have a natural tendency to establish and maintain the most effective conditions for transporting water and sediment. The streams in this study were comprised of many unvegetated to sparsely vegetated minesoils, which contribute sediment to the channels. The presence of gulleys on unvegetated banks and the absence of gulleys on moderately to well vegetated banks indicated that 


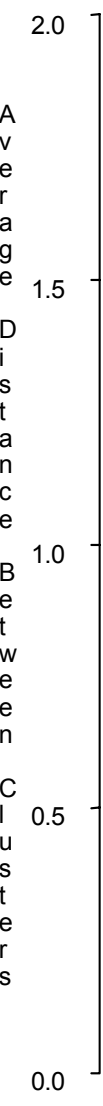

AR1 LR6 AR8 LR5 LR7 LR1 LR3 AR7 LR4 AR3 LR2 AR4 AR6 AR2 AR5 AR9 LR8 SR1 SR2 SR4 SR5 SR3

Name of Observation or Cluster 
bare minesoils generated a greater amount of sediment to channels. These results correlate with the findings of Curtis (1974). He reported that exposed surfaces of minesoils experience accelerated weathering and erosion that contribute many times more sediment and runoff to local streams than vegetated undisturbed watersheds. These bare areas are still adjusting and as a result of the high erosion rates and movement of particles, vegetation is having a difficult time establishing.

Additional sediment was contributed to these streams through undercut banks located on both vegetated and unvegetated banks, resulting in bank failures. Curtis (1971) found that mass movement on unconsolidated, sparsely vegetated minesoils was an additional source of sediment supply. The results in this study reflect the finding of Curtis (1971) and suggest that undercut banks may continue to contribute sediment after streambanks become vegetated.

McCabe (1985) determined changes in rates of erosion and deposition for the previous eight years in the Beaver Creek watershed in Kentucky. He found gullies on spoil banks had widened and deepened, creating incision that was greater upstream than downstream and reduced channel gradient. He concluded that downcutting of gullies has continued, but at a reduced rate. The minesoils in this study have been exposed for the past $40+$ years, thus the further downcutting of gulleys is expected to occur at a slow rate, corresponding to the results of McCabe (1985).

In these streams, upstream reaches are generally entrenched. Entrenchment may be stopped if the channel floor becomes armored by particles that are too large to be entrained on a lower stream gradient (Ritter et al, 2002) or if resistant bedrock is reached. Sediment has accumulated in wider channels, while narrower channels downstream 
appear to inhibit the transport of sediment. Aggradation and degradation were evident throughout the channels. Culverts located throughout these channels further impeded sediment movement. These results corresponded with findings of Tousinhthiphonexay (1982), who reported that most of the sediment eroded from spoil piles is not transmitted down the length of streams, but is trapped in aggrading reaches near stream headwaters.

Perhaps the most dominant response of channels in this study to changes extending over a graded time span has been slope alteration. Channel gradients have likely adjusted to counteract changes in sediment supply and discharge rates. Knickpoints provide evidence of such changes in Slaty Fork and Larch Run. These streams were comprised of aggrading reaches, followed by steeper bedrock reaches. Channel gradients will continue to adjust in response to discharge and channel morphology to provide the velocity required to transport the sediment load.

The present channels of three Beaver Creek tributaries are the result of mining disturbances and subsequent channel adjustments. Given the number of variables that can be adjusted and the varying sensitivity of channels, predicting channel alterations is extremely difficult.

The natural tendency for every stream is to balance its slope with that of its valley and rebuild a new floodplain (Rosgen, 1996). The following is a possible progression these channels may undergo to achieve this balance. With continued bank erosion, the width-depth ratio will increase. Lateral erosion will cause the channels to widen, however bedrock or streambed armoring will limit channel incision. Channel gradient will gradually become consistent and may decrease, while sinuosity increases. At some point, the channels will be forced to narrow and incise into the floodplain; the old, wide 
channel bed becomes the floodplain. High banks consisting of terrace sediments will surround the new channel as it flows through a wider valley.

\subsection{IMPLEMENTATION OF RESTORATION TECHNIQUES}

Key to stream restoration is production of channels capable of sediment and water transport, while maintaining morphology, without aggrading or degrading. Traditional "hard" stream restoration procedures have become less common as the use of natural materials and methods have grown in popularity. Despite the method of restoration, management strategies should be designed to encompass wide variations in sensitivity to land and water-use activities. Likewise consideration of the successive mechanisms of channel response to development impacts is warranted.

The best blueprints for natural design techniques are available through observation of the natural stable form. Stable reaches or reference reaches can be used as the basis of channel re-design. A reference reach is generally a stable stream that can be used as a model for restoration designs (Rosgen, 1996). Morphologic characteristics of reference reaches can be extrapolated to unstable reaches that are the same stream type, have the same valley type, have the same valley slope, and are in the same lithologies, hydro-physiographic region, and water regime.

In this study potential reference reaches were identified, yet most unstable reaches did not satisfy the necessary requirements for data extrapolation. The most limiting constraint, stream type, quantifies multiple variables into an integrative combination of channel morphology, which can be directly identified and described.

Potential reference reaches identified include the wetland and step pool reaches unique to Sphagnum Run. The information gathered from these reaches is most easily 
transferred to Larch Run reaches two and three (the only reaches meeting nearly all the requirements needed to use the morphological characteristics of reference reaches). Additional reaches, which contain seeps, may benefit from wetland reach data. For example, seeps in Slaty Fork reaches two and three may be capable of supporting wetland vegetation to enhance resistance to bank erosion. Although the reference- step-pool reach is unlike any other reaches in the study area, its stable nature should be considered in re-designing reaches with steep gradients. Such reaches would benefit by adding steppool features to dissipate energy within the channel.

Instabilities noted in Slaty Fork and Sphagnum Run will remain for many years to come. Similar instabilities will continue in Sphagnum Run despite its present condition as the healthiest of the three streams. When considering restoration techniques, the present state of stability should be evaluated for each stream, as well as the stream type most suitable to the surrounding environment. After determining stream type, it is necessary to characterize the likely stable stream morphology based on stream type, present hydrology, and sediment regime. Existing channel conditions must be related to potential channel conditions when determining stable channel form. Restoration plans should consider the stream's future potential as conditioned by their watershed and valley features (Rosgen, 1996).

Stability for Slaty Fork and Sphagnum Run could be enhanced with increased access to the floodplain, improved bank stability and soil $\mathrm{pH}$, balanced sediment supply and transport capacity, established riparian vegetation, and controlled channel gradient. Additionally, sediment barriers such as culverts should be improved or removed and more natural design structures implemented such as cross-vanes, log vanes, erosion 
control mats, and root wads. To achieve stability, designed structures should maintain width-depth ratios and channel capacities, remain stable during major floods, and be maintenance free.

Additional research is necessary to properly implement reference reaches and natural stream design strategies within the study tributaries. The design strategies should focus on 1) stream channel monitoring of permanent cross sections for determination of vertical and lateral stability, 2) morphologic analysis of bedload and suspended load, 3) calculation of stream discharge and associated hydraulic variables, and 4) definition of basin hydrology, hydraulic geometry, and flow resistance characteristics.

\section{CONCLUSIONS}

Adjustments to channel morphology occurred as a result of a new, post-mining environment, and ensuing changes in sediment supply and vegetation. Inconsistent width-depth ratios, unstable streambanks, variable channel gradients, knickpoints, aggrading, and bedrock channels indicate that these streams are unstable and actively readjusting.

External variables including bank failures and vegetation coverage contributed to channel morphology. Bank failures were the most influential external variable. Bank erosion through undercut banks proceeded laterally, contributed to sediment load, and had an influence on other channel processes through its control on channel width. High incision and bank instabilities in upstream reaches generated additional load that caused deposition to occur in some downstream reaches. Gulleys were present only on unvegetated banks, indicating that vegetation coverage contributed to bank stability. 
With the exception of soil $\mathrm{pH}$ and resulting vegetation coverage, soil properties did not appear to directly affect channel morphology in this study.

Morphologic variables, such as channel gradient and width-depth ratio revealed the unstable nature of the streams. The dominant response of channels to changes extending over a graded time span was gradient alteration. Streams were comprised of alternating gentle, aggrading and steep, bedrock reaches. Gradients have likely adjusted in an attempt to transport an increased sediment supply. Width-depth ratios and entrenchment ratios were inconsistent throughout the channels further emphasizing channel instability.

Slaty Fork and Larch Run developed similar channel morphologies, while Sphagnum Run was different. Slaty Fork and Larch Run were similar in size with similar drainage areas. Unvegetated banks with gulleys occurred throughout these streams. Twenty-one undercut banks were observed for both Slaty Fork and Larch Run. Streambank instabilities were associated with resultant increases in bank erosion rates due to bank failures. Sphagnum Run had a significantly smaller drainage area than Slaty Fork and Larch Run. Considerably lower discharge rates and less bank instability was determined. There were no bedrock reaches and few bedrock exposures in Sphagnum Run.

Six classifications of channel types were established based on similarities between reaches. Classifications include: steep-aggrading, transition aggrading, wide-aggrading, transition bedrock, bedrock, and wetland reaches. Reaches from Slaty Fork and Larch Run correlated well with channel types defined in this study, while Sphagnum Run reaches generally did not correspond. Sphagnum Run reaches one and four were grouped 
with steep aggrading reaches, while remaining reaches were unique and did not fit any classification.

Streams have a natural tendency to establish and maintain the most effective conditions for transporting water and sediment. Nevertheless, without human intervention, instabilities noted in these streams will remain and continue for many years to come. Gulleys on streambanks will continue downcutting, but at a reduced rate. Culverts throughout these channels will impede sediment transport, until removed. Channel gradient will continue to adjust in response to discharge and channel morphology to provide the velocity required to transport the sediement load. If applied adequately natural stream channel designs would benefit the restoration of these streams. Stability for Slaty Fork and Sphagnum Run could be enhanced with increased access to the floodplain, improved bank stability and soil $\mathrm{pH}$, balanced sediment supply and transport capacity, established riparian vegetation, and controlled channel gradient.

Stable reaches or reference reaches could be used as the basis of channel redesign. Potential reference reaches were identified, yet most unstable reaches did not satisfy the necessary requirements for data extrapolation. Additional research is necessary to properly implement reference reaches and natural stream design strategies within the study tributaries. The design strategies should focus on 1) stream channel monitoring of permanent cross sections for determination of vertical and lateral stability, 2) morphologic analysis of bedload and suspended load, 3) calculation of stream discharge and associated hydraulic variables, and 4) definition of basin hydrology, hydraulic geometry, and flow resistance characteristics. 


\section{REFERENCES}

Annable, W.K. 1995. Morphological relationships of water courses in southwestern Ontario for use in natural channel designs, M.S. Thesis. University of Guelph. Guelph, Ontario.

Andrews, E. D. and Nankervis, J. M. 1995. Effective discharge and the design of channel maintenance flows for gravel-bed rivers. pp. 151-164. In: Costa, J. E., Miller, A. J., Potter, K. W., and Wilcock, P. R., eds., Natural and anthropogenic influences in fluvial geomorphology: American Geophysical Union Monograph Series 89 .

Biedenharn, D. S., Elliot, C. M., and Watson, C. C. 1997. The WES stream investigation and streambank stabilization handbook. US EPA Workshop, US Army Engineer Waterways Experiment Station, Vicksburg, MS.

Borchers, J. W., Ehlke, T. A., Mathes, M. V., Jr., and Downs, S. C. 1991 The effects of coal mining on the hydrologic environment of selected stream basins in southern West Virginia: U.S. Geological Survey Water Resource Investigations Report 844300 .

Bull, W.B. 1997. Discontinuous Ephemeral Streams. Geomorphology, 19(3-4): 227276.

Caruccio, F. T., and Geidel. 1989. Water management strategies in abating acid mine Drainage-is water diversion really beneficial. pp. 167-172. In: 1989 Proc. Multinational Conf. Mine Plan. Design., Lexington, KY. 16-17 September. University of Kentucky, Lexington $\mathrm{KY}$.

Caruccio, F. T., Geidel, G., and Williams, R. 1984. Induced alkaline recharge zones to mitigate acidic seeps. pp. 43-47. In: Prodeedings of the 1984 symposium of surface mining, hydrology, sedimentology, and reclamation, Lexington, KY.

Chambers, D. B., and Newell D. 2002. Potential effects of mountaintop removal coal mining on fluvial geomorphology and aquatic habitat. WV-Review of Literature 1929-2000. West Virginia Geologic and Economic Survey, Publication C-47.

Collier, C. R., Whetstone, G. W., and Musser, J. J. 1964. Influences of strip mining on the hydrologic environment of parts of beaver creek basin, Kentucky, 1955-59. U.S. Geological Survey Professional Paper 427-B.

Conrad, P. W., Sweigard, R. J., Yingling, J. C., Graves, D. H., and Ringe, J. M. 2002. Use of ripping to alleviate excessive compaction on reclaimed surface mine land. Society for Mining, Metallurgy, and Exploration, SME Paper 02-044. 
Curtis, W. R. 1971. Strip-mining, erosion and sedimentation: Transactions of American Society of Agricultural Engineers, 14(3): 434-436.

Curtis, W. R. 1972. Strip mining increases flood potential of mountain watersheds, In: Watersheds in Transition Proceedings. American Water Resources Association Symposium, Colorado State University. pp. 357-360.

Curtis, W. R. 1974. Sediment yield from strip-mined watersheds in eastern Kentucky. pp. 88-100. In: Second Appl. Technology. Symposium on Mined-land Reclamation. Louisville, Ky.

Curtis, W. R. 1977. Surface mining and the flood of April 1977. U.S. Forest Service Research Note NE-248.

Curtis, W. R. 1979. Surface mining and hydrologic balance. Mining Congress Journal, 65(7): 35-40.

Daniels, W.L. and Zipper, C.E. 1997. Creation and management of productive minesoils. Virginia Cooperative Extension Publication 460-121.

Dunne, T. and L. B. Leopold. 1978. Water in environmental planning. W. H. Freeman and Co., San Fransisco, CA.

Federal Interagency Stream Restoration Working Group. 1998. Stream Corridor Restoration. Principals, Processes, and Practices. Government Printing Office, Item No. 0120-A; SuDocs No. A57. 6/2:EN 3/PT.653 ISBN-0-934213-59-3.

Hawkins, J.W. 1995. Impacts on ground water hydrology from surface coal mining in Northern Appalachia. pp. 32-43. In: Proceedings of the 1995 Annual Meetings of the American Institute of Hydrology. Denver, Colorado.

Hawkins, J. W. 1998. Chapter 3: Hydrogeologic characteristics of surface-mine spoil. Office of Surface Mining, Pittsburgh, PA., accessed May 15, 2003, at URL http://www.dep.state.pa.us/dep/deptuate/minres/district/CMDP/chap03.html

Hawkins, J.W. and W.W. Aljoe. 1990. Hydrologic characterization and modeling of a heterogenous acid-producing surface coal mine spoil, Upshur County, West Virginia. pp. 47-68. In: Proceedings of the Second International Conference on the Abatement of Acid Drainage, Montreal, Quebec, Canada, Tome 1.

Hudson, H. H., and Van Haveren, B. P. 1989. History of the coal hydrology program. In Britton L. J. Anderson, C. L., Goolsby, D. A., and Van Haveren, B. P., eds. Summary of the U.S. Geological Survey and U.S. Bureau of Land Management National Coal-Hydrology program, 1974-84: U.S. Geological Survey 
Professional Paper 1464: 21-24.

Kemper, W. D., and Rosenau, R. C. 1986. Aggregate stability and size distribution. pp. 425-442. In: Klute, A. (ed). Methods of Soil Analysis, Part 1: Physical and Mineralogical Methods. No. 9, Agronomy, American Society of Agronomy, Soil Science Society of America, Madison, WI.

Kite, S. J., and Kish, P., Kwak, B., and Rhodes, A. 2002. Pre-SMCRA mine wastes and floodplain encroachment: Deadly flood hazards in southern West Virginia, USA. The Geological Society of America Abstracts with Programs, 34(6): 77.

Knighton, A.D. 1987. River channel adjustment; the downstream dimension. Institute of British Geographers, 18: 95-128.

Leliavsky, S. 1955. An introduction to fluvial hydraulics. Constable and Company Ltd., London, 257p.

Leopold, L.B., Wolman, M.G., and Miller, J.P. 1995. Fluvial processes in geomorphology. Dover Publications, NY. 509p.

Losche, C.K. and Beverarge, W.W. 1967. Soil Survey of Tucker County and part of northern Randolph County, West Virginia. U.S. Department of Agriculture Soil Conservation Service. U.S. Government Printing Office. Washington, D.C.

McCabe, J. A. 1985. Erosion and Deposition. p.32-34. In Krieger, R. A., ed. Influences of strip mining on the hydrologic environment of parts of Beaver Creek Basin, Kentucky, 1973-74. U.S. Geological Survey Professional Paper 427-D.

Messinger, T. 2003. Comparison of storm response of streams in small, unmined and valley-filled watersheds, 1999-2001, Ballard Fork, West Virginia. U.S. Geological Survey Water-Resources Investigations Report 02-4303.

Montgomery, D. R. and Buffingham, J. M. 1997. Channel-reach morphology in mountain drainage basins. Geological Society of American Bulletin, 109(5): 596-611.

Ohio Department of Natural Resources. 2003. AML problem type: mine spoil. Accessed on January 15, 2004 at http://www.ohiodnr.com/mineral/ask/minespoil.htm.

Ritter, D. F., Kochel, C. R., and Miller, J. R. 2002. Process geomorphology, fourth edition. McGraw-Hill Higher Education. New York, NY. 560p.

Rosgen, D. L. 1994. A classification of natural rivers. Elsevier Science, B. V. Amsterdam. Catena, 22: 169-199. 
Rosgen, D. L. 1996. Applied river morphology. Wildland Hydrology, Pagosa Springs, Co. 390p.

Schumm, S.A. 1960. The shape of alluvial channels in relation to sediment type. U.S. Geologic Survey Professional Paper 352-B.

Schumm, S.A. 1971. Fluvial geomorphology. In river Mechanics. Colorado State University. Fort Collins, Colorado.

Skousen, J. G., Hedin, R., and Faulkner, B. 1997. Remining in Pennsylvania and West Virginia costs and water quality changes. Green Lands, 27(3): 36-44.

Skousen, J. G., Sexstone A., and Ziemkiewicz, P. F. 2000. Acid mine drainage control and treatment. pp. 131-168. In Reclamation of Drastically Disturbed Lands. Second edition. American Society of Agronomy, Crop Science Society of America, Soil Science Society of America, Madison, WI.

Skousen, J., and Sencindiver, J. 2004. Soil properties important to stream development on mined lands. pp. 1750-1768. In: Proceedings, 2004 National Meeting of the American Society of Mining and Reclamation, Morgantown, WV.

Smith, J. 2003. An Analysis of Small Stream Networks Located on Reclaimed Surface Coal Mines, Morgantown, M. S. Thesis. West Virginia University. Morgantown, West Virginia.

Soil Survey Staff. 1996. Soil survey laboratory methods manual. Soil Survey Investigations Report No. 42. Version 3.0 National Soil Survey Center, Lincoln, NE.

Storer, D. A. 1984. Recommended soil testing procedures for the northeastern U.S. $2^{\text {nd }}$ Edition. Northeast Regional Publication No. 493.

Swan, A.R.H., and Sandilands, M. 1995. Introduction to geological data analysis. Blackwell Sciences, Inc., Cambridge, MA, 397p.

Tennessee Department of Environment and Conservation Division of Water Pollution Control Mining. 2003. Public Notice concerning applications submitted for aquatic resource alteration permits pursuant to the Tennessee Water Quality Act of 1977, T. C. A. 69-3-108. Accessed on May 2003 at http://www.state.tn.us/environment/wpc/wpcppo/mining/Robert\%20clear\%209\% 202003-05.pdf.

Tousinhthiphonexay, K. C. N. 1982. The effect of strip mining on stream morphology and behavior with emphasis on twenty-nine small watersheds central Pennsylvania. M. S. Thesis. Penn State University. 
Tousinhthiphonexay, K. C. N., and Garner, T. W. 1984. Threshold response of small streams to surface coal mining, bitiminous coal fields, central Pennsylvania. Earth Surface Processes and Landforms, 9 : 43-58.

US Department of Agriculture, Soil Conservation Service. 1977. National handbook of conservation practices. Washington, D.C., US Department of Agriculture, Soil Conservation Service.

Wiley, J. B., Evaldi, R. D., Eychaner, J. H., Chambers, D. B. 2001. Reconnaissance of stream geomorphology, low streamflow, and stream temperature in the mountaintop coal-mining region, southern West Virginia, 1999-2000. U.S. Geologic Survey Water-Resources Investigations Report 01-4092.

Wiley, J.B., Atkins, JR., J.T., and Newell, D.A. 2002. Estimating the magnitude of annual peak discharges with recurrence intervals between 1.1 and 3.0 years for rural, unregulated streams in West Virginia. U.S. Geologic Survey Water Resources Investigations Report 02-4164.

Wiley, J.B. and Brogan, F.D.B. 2003. Comparison of peak discharges among sites with and without valley fills for the July 8-9, 2001, flood in the headwaters of Clear Fork, Coal River Basin, mountain top coal mining region, southern, West Virginia. U.S. Geologic Survey open file report: 03-133.

Wischmeier, W.H., Johnson, C.B., and Cross, B.V. 1971. A soil nomograph for Farmland and construction sites. Journal of Soil and Water Conservation, 26:189-193.

Wolman, M.G. 1954. A method of sampling coarse river-bed material. Transactions of American Geophysical Union, 35: 951-956.

Wunsch, D. R., Dinger, J. S., Taylor, P. B., Carey, D. I., and Graham, C. D. R. 1996. Hydrogeology, hydrogeochemistry, and spoil sediment at a large mine-spoil area in eastern Kentucky: Star fire tract. Kentucky Geological Survey, Report of Investigations 10, Series XI, $49 \mathrm{p}$. 


\section{APPENDIX A. MINESOIL PIT DESCRIPTIONS}

Pit 1

Location: Tucker County, West Virginia.

Vegetation: Red pine, Poverty Grass, British Soldier Lichen

Parent Material: Minesoil

Slope: $5 \%$

Aspect: WNW

Described by: J. Sencindiver and K. Stephens, 5/8/01

Sampled by: K. Stephens and J. Lanham, 5/9/01

A- $\quad$ 0-5 cm; dark grayish brown (2.5Y 4/2) channery silt loam; weak fine granular structure; very friable; many very fine and fine roots; $15 \%$ rock fragments; clear wavy boundary.

Bw1 5-16 cm; dark grayish brown (2.5Y 4/2) channery silty clay loam; moderate fine subangular blocky structure; common fine strong brown (7.5YR 5/6) and yellowish brown (10YR 5/8) mottles; very friable; many very fine to medium roots; $20 \%$ rock fragments; clear wavy boundary.

Bw2 16-31 cm; dark olive brown (2.5Y 3/3) channery silty clay loam; many medium black (N 2.5/0), gray (10YR 5/1) and strong brown (7.5YR 5/6) mottles; moderate medium subangular blocky structure; friable; few very fine and fine roots; $25 \%$ rock fragments; gradual wavy boundary.

BC 31-49 cm; olive brown (2.5Y 4/3) channery clay loam; many fine and medium gray (10YR 5/1), strong brown (7.5Y 5/6) and black (N 2.5/0) mottles; weak medium and coarse subangular blocky structure; firm; few very fine roots; 25\% rock fragments; gradual wavy boundary.

C1 49-61 cm; dark grayish brown (10YR 4/2) very channery clay loam; many medium dark reddish brown (5YR 3/3), gray (10YR 5/1) and yellow (2.5Y 7/6) mottles; pockets of partially decomposed organic matter; massive, firm; few very fine roots; 35\% rock fragments; abrupt wavy boundary.

2C2 61-87 cm; black ( $\mathrm{N}$ 2.5/0) extremely channery sandy loam; few fine dark reddish brown (5YR 3/4) and few medium gray (2.5Y 6/1) and strong brown ( 7.5YR 5/6) mottles; massive; friable; $80 \%$ rock fragments; gradual wavy boundary.

2C3 87-120+ cm; black (N 2.5/0) extremely channery sandy loam with pockets of gray (7.5YR 5/1) and strong brown (7.5YR 5/6) silty clay loam; massive; very friable; $75 \%$ rock fragments. 
Pit 2

Location: Tucker County, West Virginia. N 39 09’ 40.3”' W 79²4’ 54.6”

Vegetation: Red pine forest about 28 years old about 32 feet in height, Virginia Pine Forest about 28 years old; about 16 feet in height.

Parent Material: Minesoil

Slope: $9 \%$

Aspect: W

Described by: J. Sencindiver and J. Gorman, 2/6/01

Sampled by: J. Sencindiver and B. Cooley, 2/13/01

A- $\quad 0-5 \mathrm{~cm}$; dark grayish brown (2.5Y 4/2) channery silt loam; weak fine granular structure; very friable; common fine and very fine roots; $15 \%$ rock fragments; abrupt wavy boundary.

Bw- 5-12 cm; mixed very dark gray (10YR 3/1), gray (10YR 6/1) and red (2.5YR 5/8) channery silty clay loam; weak medium and fine subangular blocky structure; friable; common very fine to medium roots; $25 \%$ rock fragments; clear wavy boundary.

CB 12-38 cm; black (10YR 2/1) and dark gray (10YR 4/1) channery silty clay loam; weak coarse platy structure; friable; common fine and very fine roots; $25 \%$ rock fragments; clear wavy boundary.

C1 38-61 cm; black (10YR 2/1), dark grayish brown (2.5Y 4/2) and yellowish brown (10YR 5/4) channery silty clay loam; massive; friable; few very fine and fine roots; $30 \%$ rock fragments; abrupt wavy boundary.

C2 61-85 cm; dark grayish brown (10YR 4/2) and yellowish brown (10YR 5/4) channery silty clay loam; massive; friable; common fine and medium red (2.5YR 4/8) and common fine and medium grayish brown (10YR 5/2) mottles; few very fine to medium roots; $25 \%$ rock fragments; clear wavy boundary.

C3 85-109 cm; brown (10YR 4/3) and strong brown (7.5YR 5/8) very channery silty clay loam; massive; friable; few very fine to medium roots; $50 \%$ rock fragments; clear wavy boundary.

C4 109-141+ cm; dark grayish brown (10YR 4/2) extremely channery silty clay loam; massive; friable; $75 \%$ rock fragments. 
Pit 3

Location: Tucker County, West Virginia. N 3909’23.1” W 79²5’27.2”

Vegetation: Red and Scotch pines, autumn olive, grasses and forbs.

Parent Material: Minesoil

Slope: $28 \%$

Aspect: SW

Described by: J. Sencindiver and K. Stephens, 5/8/01

Sampled by: K. Stephens and J. Lanham, 5/9/01

Oi- $\quad 0-1 \mathrm{~cm}$, needle litter

A- $\quad$ 1-4 cm; dark gray (10YR 4/1) loam; moderate medium granular structure; friable, many very fine and fine roots; $5 \%$ rock fragments; abrupt wavy boundary.

AB- 4-10 cm; dark gray (10YR 4/1) channery clay loam; fine brown (7.5YR 4/3) mottles; weak fine subangular blocky structure; friable; many very fine to coarse roots; $20 \%$ rock fragments; clear wavy boundary.

Bw- 10-35 cm; brown (7.5YR 4/3) channery silty clay loam; many fine and medium strong brown (7.5YR 5/6), light olive brown (2.5YR 5/4), gray (7.5YR 5/1) mottles; weak medium and coarse subangular blocky structure; firm; common very fine and coarse roots; $25 \%$ rock fragments; clear wavy boundary.

C1- 35-86 cm; dark grayish brown (10YR 4/2) very channery silty clay loam; many fine strong brown (7.5YR 5/6), light grayish brown (10YR 6/2) and light yellowish brown (10YR 6/4) mottles massive; firm; few very fine to coarse roots; $40 \%$ rock fragments; gradual wavy boundary.

C2- 86-133 cm; dark gray (10YR 4/1) and yellowish brown (10YR 5/4) very channery clay loam with pockets of brown (7.5YR 4/4) silty clay loam; massive; friable with pockets of firm; few very fine to coarse roots; $45 \%$ rock fragments, gradual wavy boundary.

C3- 133-190+ cm, dark gray (10YR 4/1) and yellowish brown (10YR 5/8) very channery silty clay loam with pockets of yellowish red (5YR 4/6), yellowish brown ((10YR 5/8), gray (7.5YR 6/1) and gray (10YR 6/1) silty clay; massive; firm and friable; few fine lithochromatic gray (10YR 6/1) and light yellowish brown (10YR 6/4, 10YR 5/8) mottles; few very fine and fine roots; $45 \%$ rock fragments. 
Pit 4

Location: Tucker County, West Virginia. N 3909’20.8” W 79²5’26.6”

Vegetation: Red pine forest about 23 years old, bristly locust.

Parent Material: Minesoil

Slope: $24 \%$

Aspect: W

Described and sampled by: J. Sencindiver and J. Gorman, 2/6/01

A - $\quad$ 0-8 cm; grayish brown (2.5Y 5/2) and dark gray (2.5Y 4/1) channery silt loam; weak medium granular structure; friable; common very fine to medium roots; $30 \%$ rock fragments; clear wavy boundary.

Bw1 - 8-30 cm; gray (10YR 5/1) and grayish brown (2.5Y 5/2) channery silty clay loam; common medium yellowish brown (10YR 5/8) and few medium strong brown (7.5YR 5/6) mottles; weak medium subangular blocky structure ; friable; common very fine and fine roots; $30 \%$ rock fragments; abrupt wavy boundary.

Bw2 - 30-56 cm; dark gray (10YR 4/1) channery silt loam; many fine and medium yellowish brown (10YR 5/8) and strong brown (7.5YR 5/6) mottles; weak medium subangular blocky structure; friable; few very fine and fine roots, $30 \%$ rock fragments; abrupt wavy boundary.

Bw3 - 56-99 cm; very dark gray (10YR 3/1) very channery clay loam; common fine and meduim yellowish brown (10YR 5/8) and strong brown (7.5YR 5/6) mottles; weak fine subangular blocky structure; very friable; common very fine and fine roots; $50 \%$ rock fragments; clear wavy boundary.

C1 - 99-206 cm; dark grayish brown (2.5Y 4/2) very channery clay loam; few fine and medium gray (10YR 6/1) and common fine and medium yellowish brown (10YR 5/8), and strong brown (7.5YR 5/6) mottles; massive; very friable; common very fine to coarse roots; $50 \%$ rock fragments; gradual wavy boundary.

C2 - 206-250+ cm; dark grayish brown (10YR 4/2) very channery silty clay loam; common fine and medium yellowish brown (10YR 5/8) and strong brown (7.5YR 5/6) and few fine and medium gray (10YR 6/1) mottles; massive; friable; $50 \%$ rock fragments. 


\section{APPENDIX B. GEOMORPHIC AND HYDRAULIC EQUATIONS}

\section{Geomorphic Equations}

- Cross sectional area of bankfull stage (Abf) $=$ wbf/D

Wbf = width of the channel at bankfull stage $\mathrm{D}=$ depth

- $\quad$ Mean depth, $(\mathrm{d}$-mean $)=\mathrm{Abf} / \mathrm{wbf}$

Abf $=$ cross sectional area of bankfull stage wbf $=$ width of stream at bankfull stage

- $\quad$ Wetted perimeter, $(\mathrm{P})=\mathrm{W}^{*} 2 \mathrm{D}$

$\mathrm{W}=$ width

$\mathrm{D}=$ depth

- $\quad$ Hydraulic radius $(\mathrm{R})=\mathrm{Abf} / \mathrm{P}$

Abf $=$ cross sectional area of bankfull stage

$\mathrm{P}=$ wetted perimeter

1

- $\quad$ Width depth ratio, $(\mathrm{W} / \mathrm{D}$ ratio) $=$ wbf/d-mean

wbf = width of channel at bankfull stage

d-mean $=$ mean depth

- $\quad$ Entrenchment ratio $(\mathrm{ER})=\mathrm{wfpa} / \mathrm{wbf}$

- $\quad$ Pool to riffle ratio = length of pools/ length of riffles

- $\quad$ Sinuosity = stream length/valley length

\section{Channel Hydraulic Equations}

- Velocity, $(\mathrm{V})=\underline{1.487 * \mathrm{R}^{2 / 3} *(\mathrm{~S} / 100)^{1 / 2}}=(\mathrm{ft} / \mathrm{sec})$

$\mathrm{R}=$ hydraulic radius

$\mathrm{S}=$ slope

$\mathrm{n}=$ mannings coefficient

- Discharge, $(\mathrm{Q})=\mathrm{V}^{*} \mathrm{~A}=(\mathrm{cfs})$

$\mathrm{V}=$ velocity

$\mathrm{A}=$ cross sectional area 
- Shear stress $\left(\tau_{c}\right)=\gamma^{*} \mathrm{R} * \mathrm{~S}=\left(\mathrm{lbs} / \mathrm{ft}^{2}\right)$

$$
\begin{aligned}
& \gamma=62.4=\text { density of water } \\
& R=\text { hydraulic radius } \\
& S=\text { slope }
\end{aligned}
$$

- Shear velocity $=(g * R * S)^{1 / 2}=(f t / s e c)$

$$
\begin{aligned}
& \mathrm{g}=32.2 \text { = gravitational acceleration } \\
& \mathrm{R}=\text { hydraulic radius } \\
& \mathrm{S}=\text { slope }
\end{aligned}
$$

- Unit stream power, $(\mathrm{w})=\underline{\text { shear stress }}=(\mathrm{lbs} / \mathrm{ft} / \mathrm{sec})$

$$
\mathrm{W}=\text { width of flow at bankfull }
$$

- $\quad$ Froude number $=\mathrm{V}^{2} / \mathrm{gd}$

$$
\begin{aligned}
& \mathrm{V}=\text { velocity } \\
& \mathrm{g}=32.2 \text { (gravitational acceleration) } \\
& \mathrm{d}=\text { depth }
\end{aligned}
$$

- Friction factor $=$ velocity/shear velocity 


\section{APPENDIX C. STREAM REACH DATA \\ LARCH RUN}

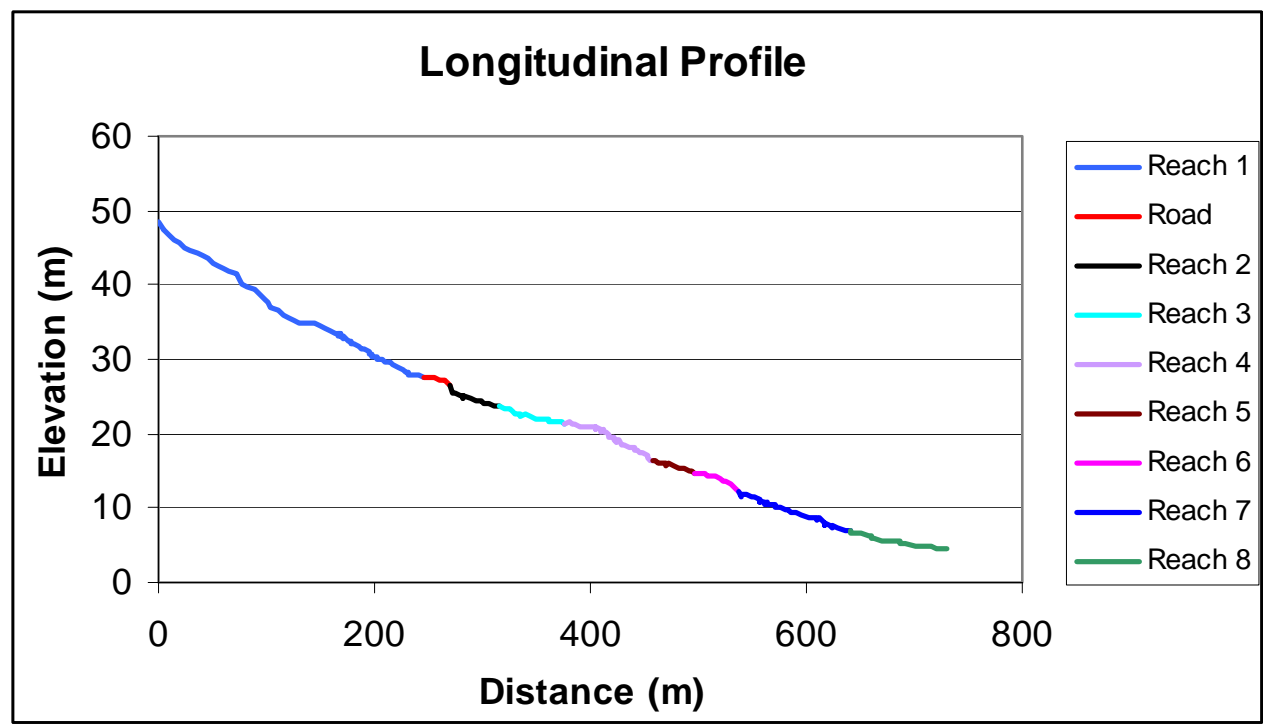

Site Location: Where surveying began

Latitude: 3909'38.6'’ N

Longitude: $79^{\circ} 24^{\prime} 39.3^{\prime \prime}$ ' W

Drainage area: $143,522 \mathrm{~m}^{2}$

Stream Description: Larch Run was similar in size and characteristics as Slaty Fork. This stream was comprised of eight reaches: six aggrading, one transitional, and one bedrock. Bank failures were common throughout this tributary.

Relationships below were determined by averaging values from reaches.

\section{Profile Characteristics}

Mean bankfull stage width: $3.72 \mathrm{~m}$

Mean bank height: $2.71 \mathrm{~m}$

Mean bank slope angle: $54^{\circ}$

Mean pool to riffle ratio: $1: 2.5$

Total channel gradient: $5.15 \%$

\author{
Morphological Relationships \\ Mean width to depth ratio: 32.70 \\ Mean entrenchment ratio: 1.45 \\ Total Sinuosity: 1.35 \\ Total BEHI rating: 37.30 (High)
}

\section{Hydraulic Characteristics}

Measn bankfull discharge (3yr): 168.36 l/s

Mean bankfull discharge (1.5yr): $106.38 \mathrm{l} / \mathrm{s}$

Mean stream power (3yr): $1.53 \mathrm{~kg}^{3} / \mathrm{m} / \mathrm{s}$

Mean stream power (1.5yr): $0.97 \mathrm{~kg}^{3} / \mathrm{m} / \mathrm{s}$ 


\section{LARCH RUN: REACH ONE}

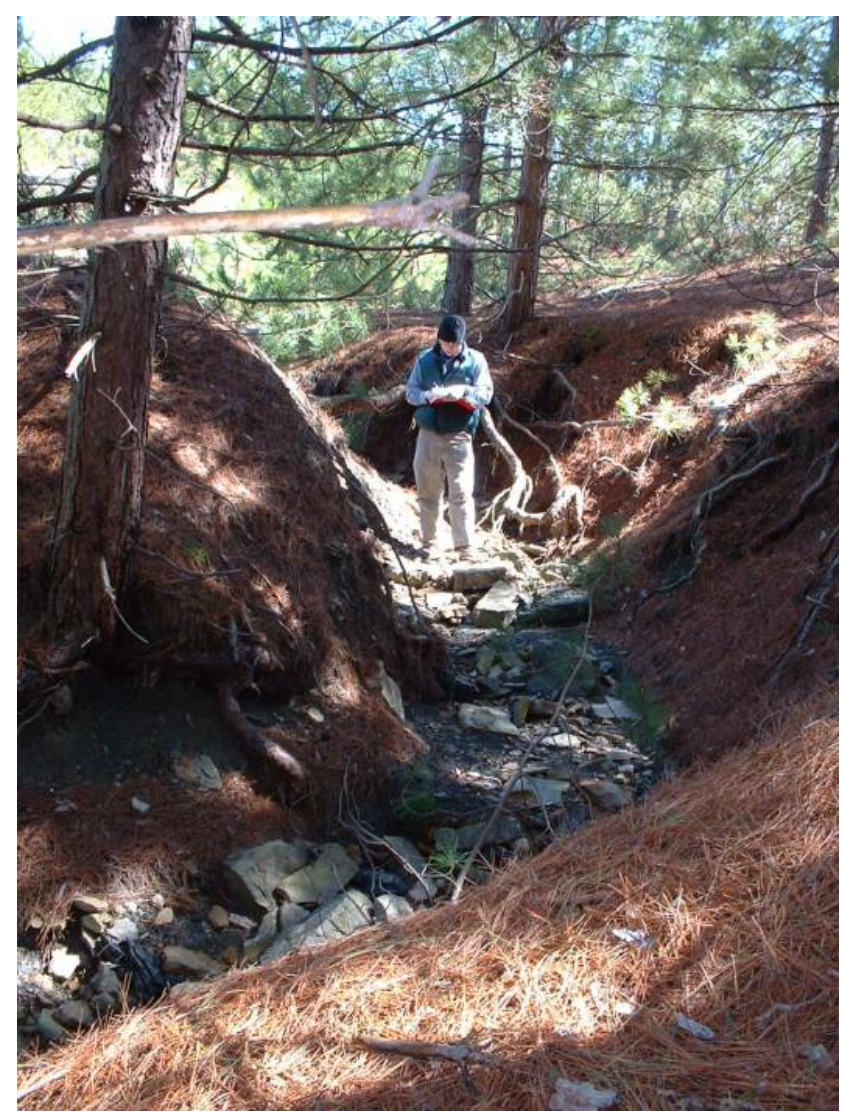

Profile Characteristics

Bankfull stage width: $3.05 \mathrm{~m}$

Mean bankfull stage depth: $0.2 \mathrm{~m}$

Mean bank height: $1.5 \mathrm{~m}$

Bank slope angle: $53^{\circ}$

Pool to riffle ratio: $1: 3.5$

Channel gradient: $8.48 \%$

Morphological Relationships

Width to depth ratio: 18.7

Entrenchment: 1.6

Sinuosity: 2.33

Bank height/bankfull stage height: 4.8

Rooting depth/bank height: 0.04

BEHI Rating: 38.9 (High)

\section{Hydraulic Characteristics}

Bankfull discharge (3yr): 135.28 l/s

Bankfull discharge (1.5yr): $85.59 \mathrm{l} / \mathrm{s}$

Stream power (3yr): $1.71 \mathrm{~kg}^{3} / \mathrm{m} / \mathrm{s}$

Stream power (1.5yr): $1.081 .71 \mathrm{~kg}^{3} / \mathrm{m} / \mathrm{s}$

\section{Upstream View}

Vegetation Characteristics: Vegetation covers about 14\% of the channel banks. Red pines occurred at a very low density on both channel banks.

Channel Description: Moderately entrenched with a very steep gradient. The dominant channel material were gravel, cobble and to a lesser degree boulder. Streambanks consisted of loam and silt loam textures. A slump was observed in this reach.

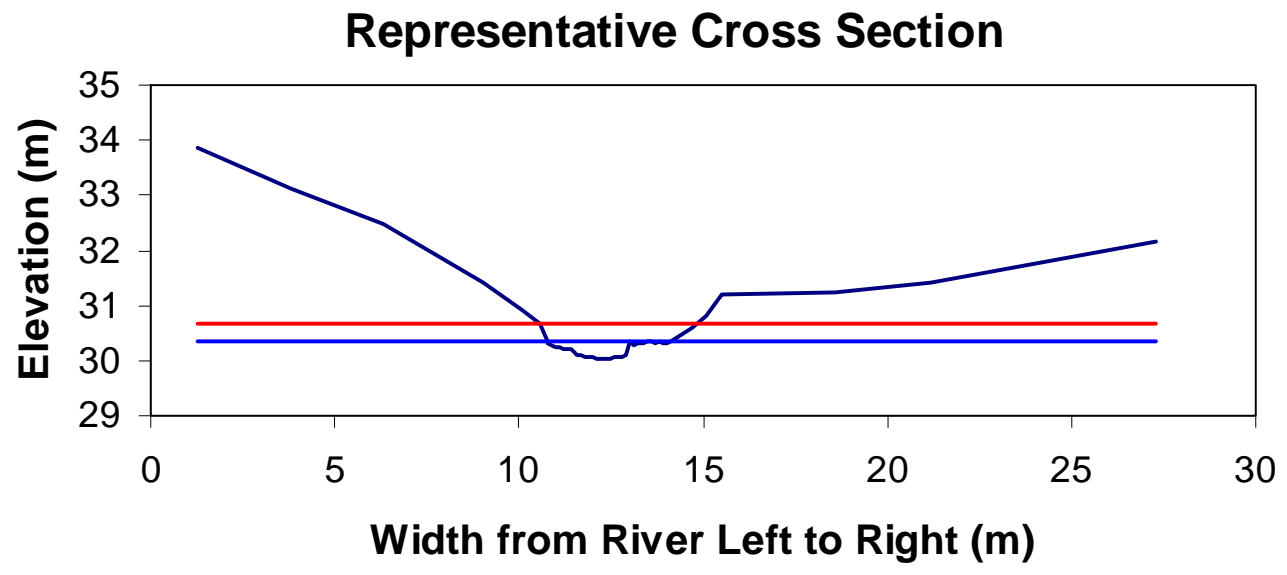




\section{Sediment Characteristics}

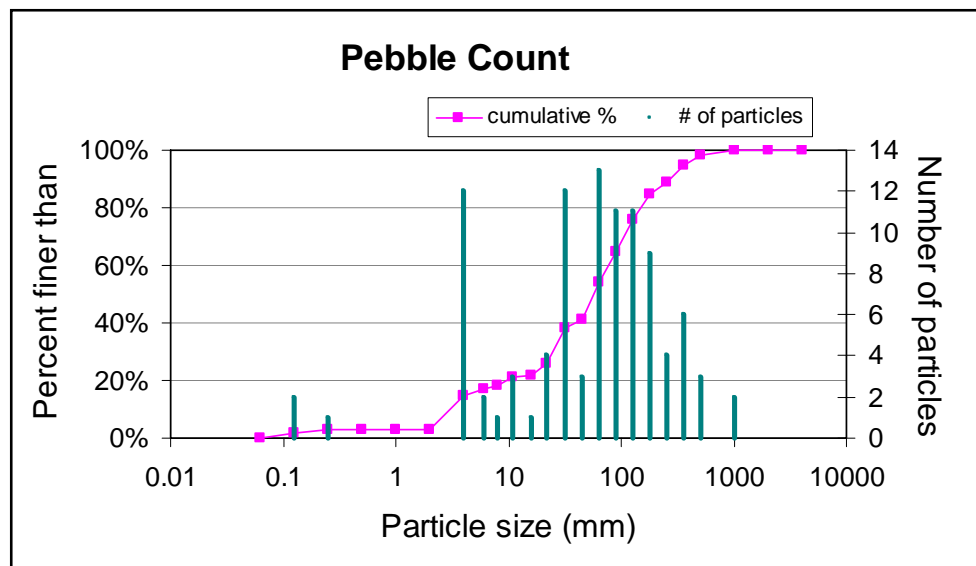

Size Percent Less than (mm): Based on sediment particles only

\begin{tabular}{|c|c|c|c|c|c|c|c|c|c|c|}
\hline \multicolumn{3}{|c|}{ D16 } & D35 & D50 & \multicolumn{2}{|c|}{ D65 } & \multicolumn{2}{|l|}{ D84 } & \multicolumn{2}{|l|}{ D95 } \\
\hline \multicolumn{3}{|c|}{4.9} & 29.1 & 57.4 & \multicolumn{2}{|c|}{90} & \multicolumn{2}{|l|}{173} & \multicolumn{2}{|l|}{362} \\
\hline \multicolumn{11}{|c|}{ Percent by Substrate Type: Based on total count } \\
\hline \multicolumn{3}{|c|}{ Silt/Clay } & Sand & \multicolumn{2}{|l|}{ Gravel } & Cobble & \multicolumn{2}{|c|}{ Boulder } & \multicolumn{2}{|c|}{ Bedrock } \\
\hline & \multicolumn{2}{|c|}{$0 \%$} & $3 \%$ & \multicolumn{2}{|l|}{$51 \%$} & $35 \%$ & \multicolumn{2}{|c|}{$11 \%$} & \multicolumn{2}{|l|}{$0 \%$} \\
\hline \multicolumn{7}{|c|}{$\begin{array}{l}\text { Right Bank } \\
\text { Texture: Loam } \\
\text { Aggregate Stability: } 17.2 \% \\
\text { LOI Organic Matter: } 13.32 \% \\
\text { H202 Organic Matter: } 3.7 \% \\
\text { Rock Fragments: } 7 \% \\
\text { K Factor: } 0.24 \\
\text { LS Factor: } 4.6 \\
\text { C:N Ratio: } 1: 0.02 \\
\text { pH: } 3.47\end{array}$} & \multicolumn{4}{|c|}{$\begin{array}{l}\text { Left Bank } \\
\text { Texture: Loam } \\
\text { Aggregate Stability: } 65.8 \% \\
\text { LOI Organic Matter: } 17.23 \% \\
\text { H202 Organic Matter: } 6.45 \% \\
\text { Rock Fragments: } 20 \% \\
\text { K Factor: } 0.25 \\
\text { LS Factor: } 3.8 \\
\text { C:N Ratio: } 1: 0.02 \\
\text { pH: } 3.47\end{array}$} \\
\hline \multicolumn{11}{|c|}{ Particle Size (3A1) } \\
\hline \multicolumn{6}{|c|}{ Total $(\mathrm{mm})$} & \multicolumn{5}{|c|}{ Sand $(\mathrm{mm})$} \\
\hline & $\begin{array}{c}\text { Clay } \\
(<.002)\end{array}$ & $\begin{array}{l}\text { Fine silt } \\
(.02-.002)\end{array}$ & $\begin{array}{c}\text { Coarse Silt } \\
(.05-.02)\end{array}$ & $\begin{array}{l}\text { Total Silt } \\
(.05-.002)\end{array}$ & $\begin{array}{l}\text { Sand } \\
(2-.05)\end{array}$ & $\begin{array}{c}\text { Very } \\
\text { Coarse } \\
(2.0-1.0)\end{array}$ & $\begin{array}{c}\text { Coarse } \\
(1.0-5) \\
\end{array}$ & $\begin{array}{c}\text { Medium } \\
(.5-.25)\end{array}$ & \begin{tabular}{|c} 
Fine \\
$(.25-.1)$
\end{tabular} & $\begin{array}{c}\text { Very } \\
\text { Fine } \\
(.1-.05) \\
\end{array}$ \\
\hline & 18.64 & 29.34 & 20.10 & 49.44 & 31.92 & 0.87 & 0.87 & 0.58 & 0.46 & 0.46 \\
\hline & 15.88 & 21.56 & 19.86 & 41.42 & 42.70 & 0.15 & 0.46 & 0.835 & 1.165 & 1.14 \\
\hline
\end{tabular}




\section{LARCH RUN: REACH TWO}

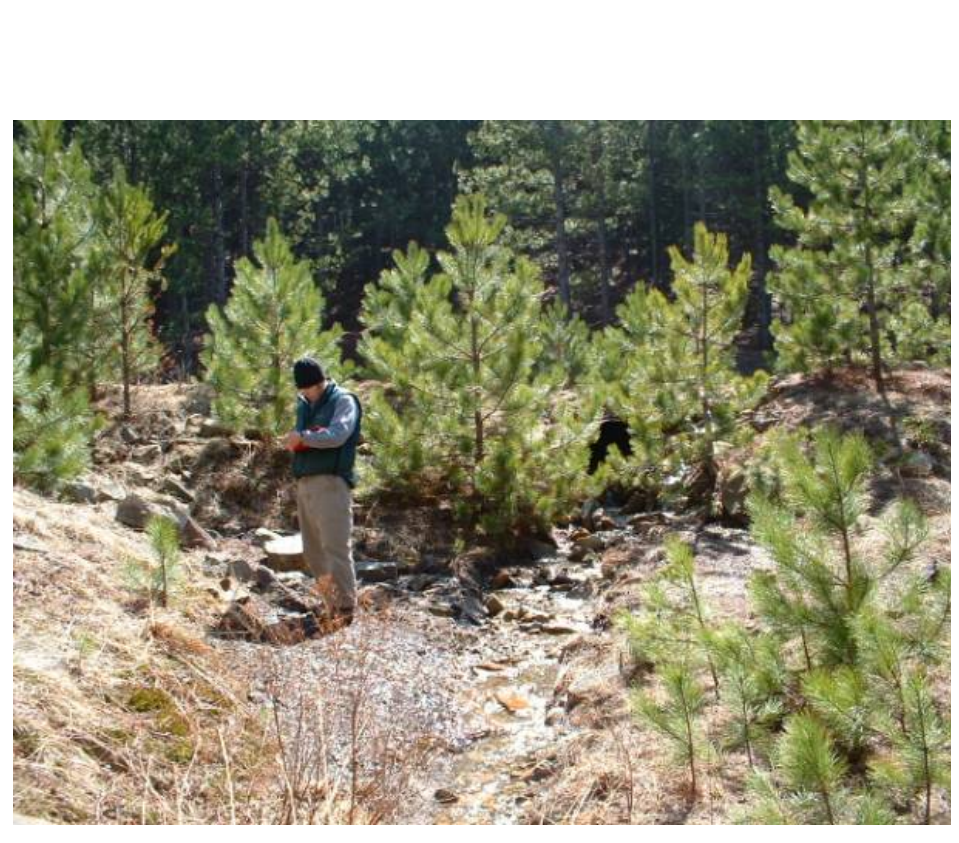

Upstream View

\section{Profile Characteristics}

Bankfull stage width: $3.2 \mathrm{~m}$

Mean bankfull stage depth: $0.1 \mathrm{~m}$

Mean bank height: $4.0 \mathrm{~m}$

Bank slope angle: $61^{\circ}$

Pool to riffle ratio: $1: 9$

Channel gradient: $4.50 \%$

\section{Morphological Relationships}

Width to depth ratio: 30.6

Entrenchment: 1.7

Sinuosity: 1.44

Bank height/bankfull stage height: 16

Rooting depth/bank height: 0.02

BEHI Rating: 43.9 (Very High)

\section{Hydraulic Characteristics}

Bankfull discharge (3yr): 146.81 1/s

Bankfull discharge (1.5yr): $92.84 \mathrm{l} / \mathrm{s}$

Stream power (3yr): $0.79 \mathrm{~kg}^{3} / \mathrm{m} / \mathrm{s}$

Stream power (1.5yr): $0.50 \mathrm{~kg}^{3} / \mathrm{m} / \mathrm{s}$

Vegetation Characteristics: Vegetation covered about 25\% of the channel banks. The left bank was covered with very sparse grasses, while red pines occurred at the top of the bank. Red pine, red spruce, autumn olive, one quaking aspen, blueberry patches and grasses occurred at a sparse to moderate density on the right bank. The riparian vegetation consisted of sparse to moderate grasses and sedges.

Channel Description: Moderately entrenched with a steep gradient. The channel materials were gravel. Streambanks consisted of loam textures.

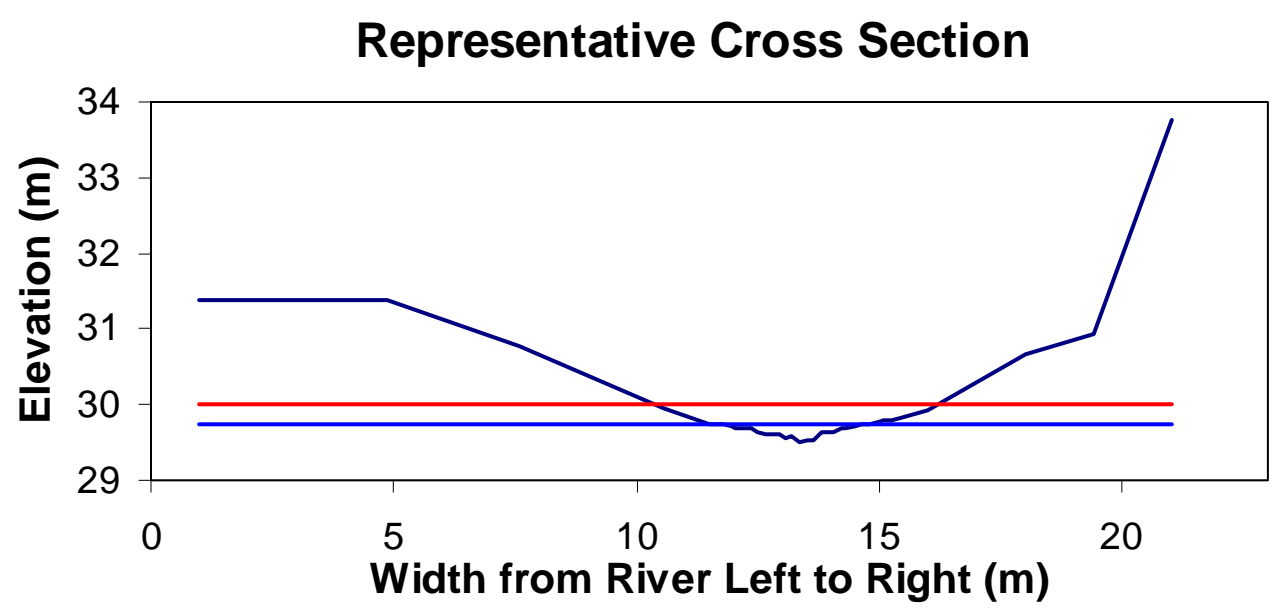




\section{Sediment Characteristics}

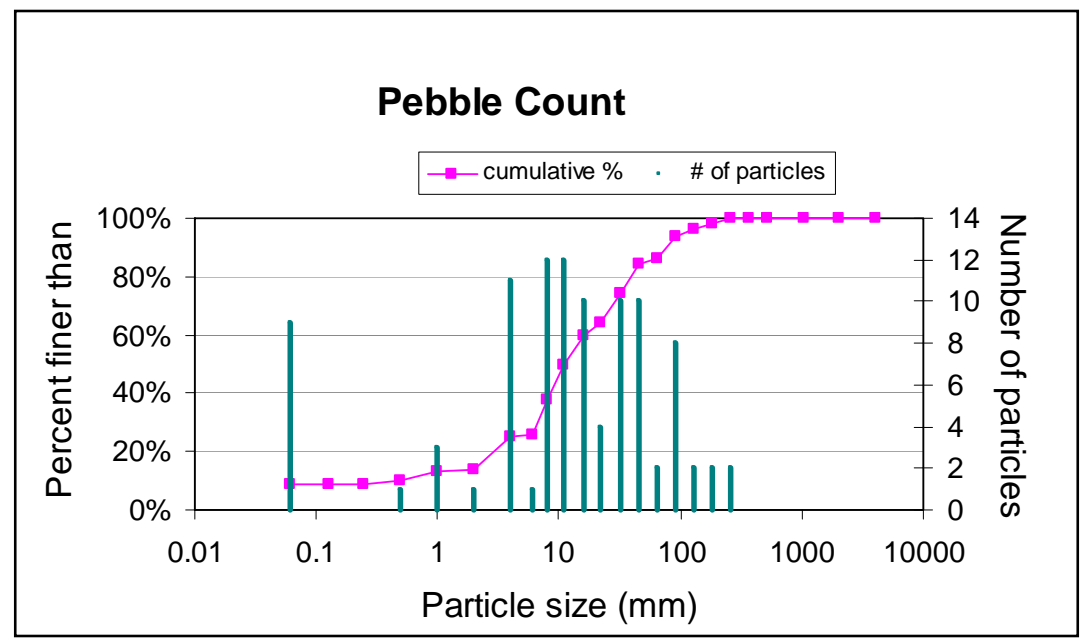

Size Percent Less than (mm): Based on sediment particles only

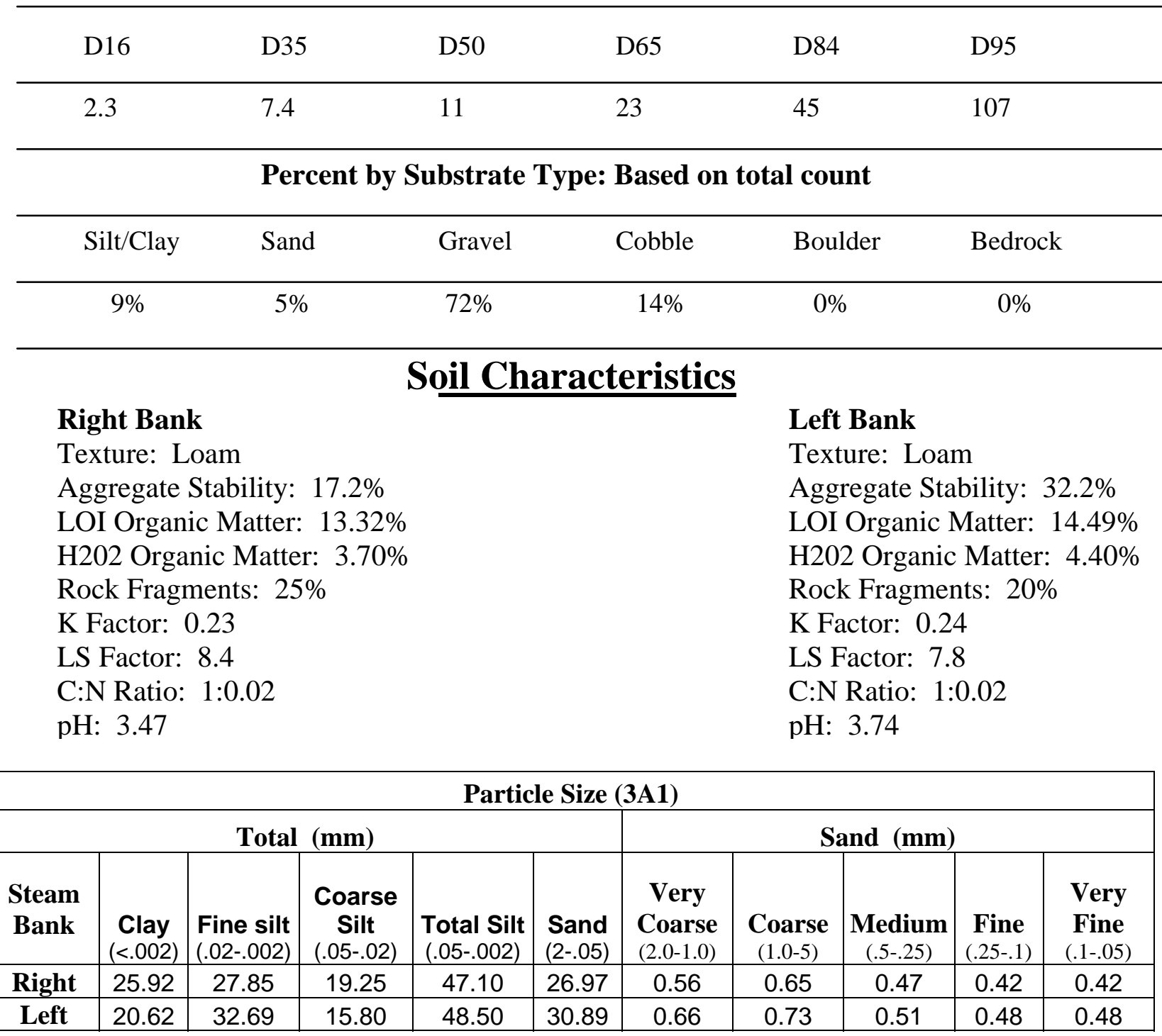




\section{LARCH RUN: REACH THREE}

\section{Profile Characteristics}

Bankfull stage width: $7.3 \mathrm{~m}$

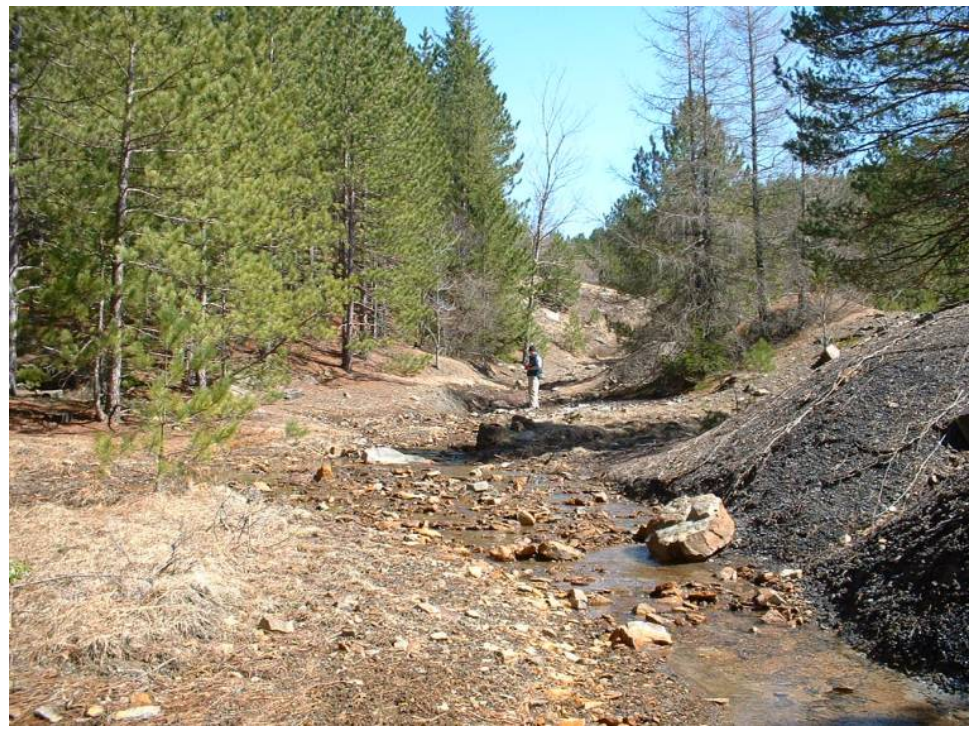

Mean bankfull stage depth: $0.1 \mathrm{~m}$

Mean bank height: $0.9 \mathrm{~m}$

Bank slope angle: $43^{\circ}$

Pool to riffle ratio: $1: 1.5$

Channel gradient: $3.68 \%$

\section{Morphological Relationships}

Width to depth ratio: 73.2

Entrenchment: 1.4

Sinuosity: 1.02

Bank height/bankfull stage height: 4.3

Rooting depth/bank height: 0.07

BEHI Rating: 37.9 (High)

\section{Hydraulic Characteristics}

Bankfull discharge (3yr): 156.23 l/s

Upstream View

Bankfull discharge (1.5yr): $98.76 \mathrm{l} / \mathrm{s}$

Stream power (3yr): $2.36 \mathrm{~kg}^{3} / \mathrm{m} / \mathrm{s}$

Stream power (1.5yr): $1.49 \mathrm{~kg}^{3} / \mathrm{m} / \mathrm{s}$

Vegetation Characteristics: Vegetation covered about 28\% of the channel banks. Red pines with a grassy understory dominated the right bank, while spruces occurred at a lesser degree. The left bank primarily consisted of minesoils with a few red pines, scotch pines, and larches occurring at the upstream portion of the reach. The riparian vegetation was comprised of sparse grasses and sedges.

Channel Description: Moderately entrenched with a moderate gradient. The dominant channel materials were gravel with cobble occurring at a smaller degree. Streambanks consisted of silt loam and clay loam textures. Small gulleys were present throughout this reach.

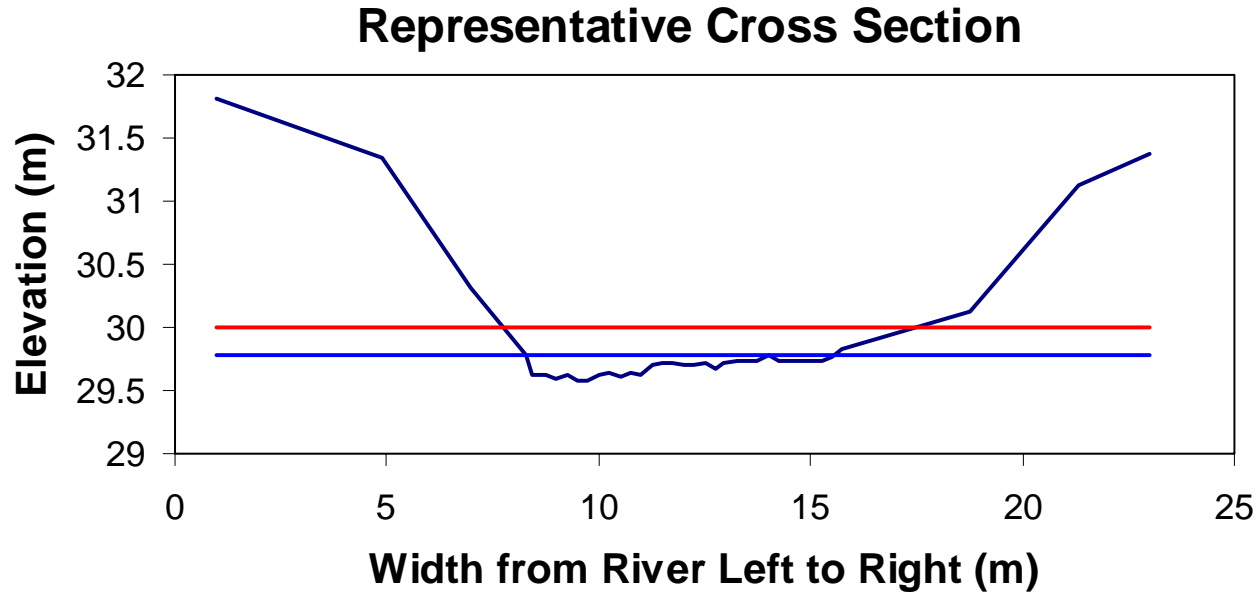




\section{Sediment Characteristics}

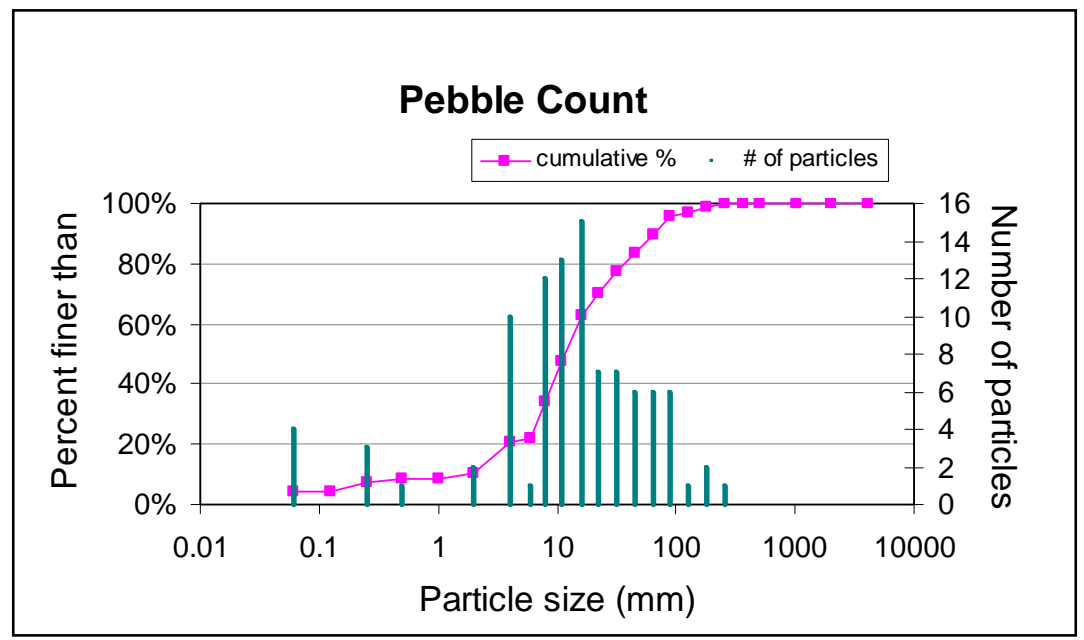

Size Percent Less than (mm): Based on sediment particles only

\begin{tabular}{cccccc}
\hline D16 & D35 & D50 & D65 & D84 & D95 \\
\hline 2.9 & 8.2 & 11.7 & 18 & 46 & 86 \\
\hline Silt/Clay & Sand & Gravel & Cobble & Boulder & Bedrock \\
\hline $4 \%$ & $6 \%$ & $76 \%$ & $10 \%$ & $0 \%$ & $4 \%$ \\
\hline
\end{tabular}

\section{$\underline{\text { Soil Characteristics }}$}

Right Bank

Texture: Silt Loam

Aggregate Stability: 25\%

LOI Organic Matter: 13.70\%

H202 Organic Matter: 3.90\%

Rock Fragments: 10\%

K Factor: 0.23

LS Factor: 1.0

C:N Ratio: 1:0.02

pH: 3.15
Left Bank

Texture: Clay Loam

Aggregate Stability: $7.8 \%$

LOI Organic Matter: 5.82\%

H202 Organic Matter: 4.45\%

Rock Fragments: 30\%

K Factor: 0.21

LS Factor: 4.3

C:N Ratio: 1:0.02

pH: 3.81

\begin{tabular}{|c|c|c|c|c|c|c|c|c|c|c|}
\hline \multicolumn{11}{|c|}{ Particle Size (3A1) } \\
\hline \multicolumn{6}{|c|}{ Total (mm) } & \multicolumn{5}{|c|}{ Sand (mm) } \\
\hline $\begin{array}{c}\text { Steam } \\
\text { Bank }\end{array}$ & $\begin{array}{c}\text { Clay } \\
(<.002)\end{array}$ & $\begin{array}{l}\text { Fine silt } \\
(.02-.002)\end{array}$ & $\begin{array}{c}\text { Coarse Silt } \\
(.05-.02)\end{array}$ & $\begin{array}{l}\text { Total Silt } \\
(.05-.002)\end{array}$ & $\begin{array}{l}\text { Sand } \\
(2-.05)\end{array}$ & $\begin{array}{l}\text { Very } \\
\text { Coarse } \\
(2.0-1.0)\end{array}$ & $\begin{array}{c}\text { Coarse } \\
(1.0-5)\end{array}$ & $\begin{array}{c}\text { Medium } \\
(.5-.25)\end{array}$ & $\begin{array}{c}\text { Fine } \\
(.25-.1)\end{array}$ & $\begin{array}{c}\text { Very } \\
\text { Fine } \\
(.1-.05)\end{array}$ \\
\hline Right & 21.84 & 34.19 & 16.60 & 50.79 & 27.37 & 0.70 & 0.72 & 0.45 & 0.36 & 0.33 \\
\hline Left & 29.17 & 30.45 & 11.67 & 42.12 & 28.71 & 0.55 & 0.77 & 0.68 & 0.40 & 0.24 \\
\hline
\end{tabular}




\section{LARCH RUN: REACH FOUR}

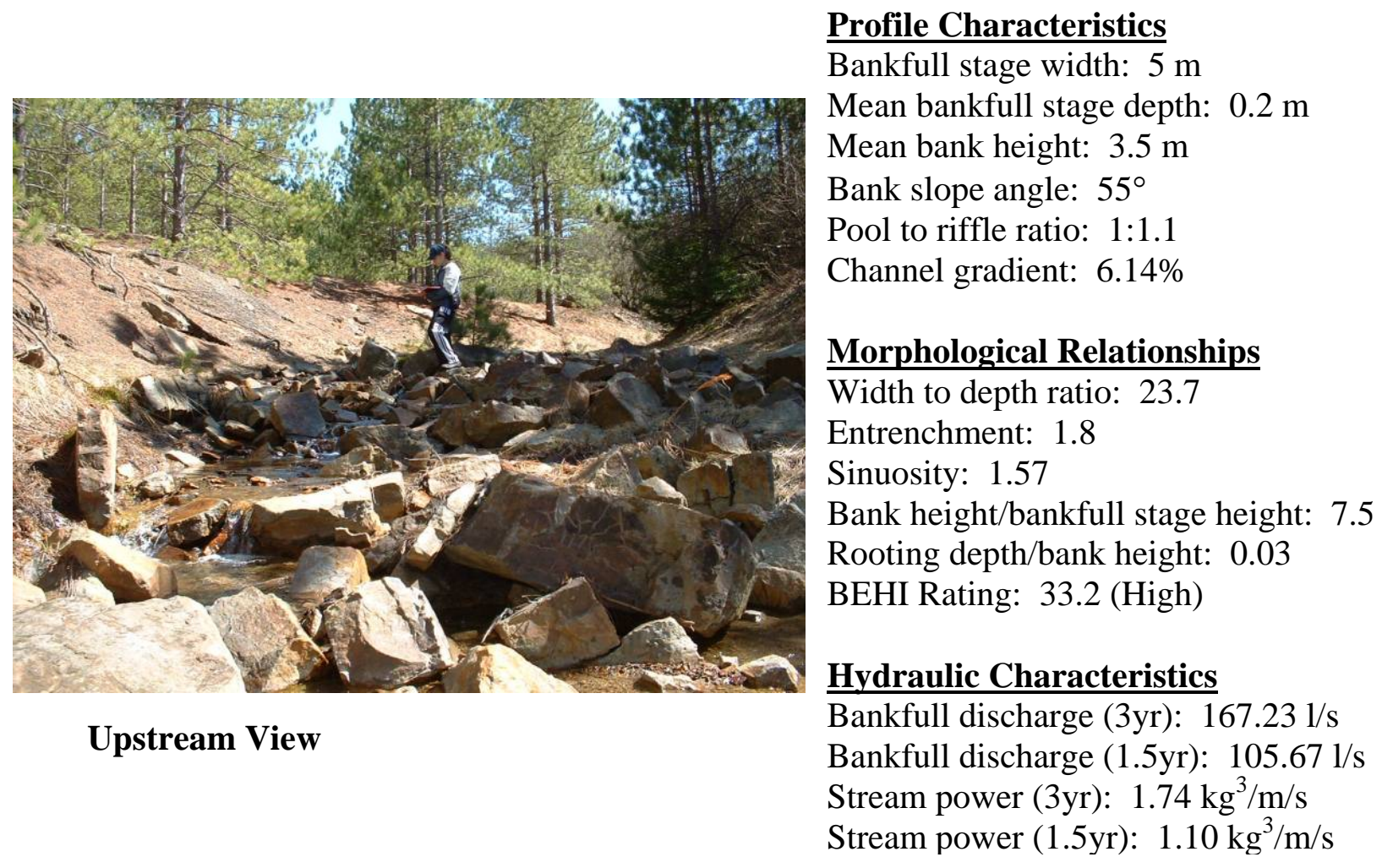

Vegetation Characteristics: Vegetation covered about 33\% of the channel banks. Species found in this area included red pines, blueberry, and grasses.

Channel Description: Moderately entrenched with a steep gradient. The dominant channel materials were gravel, while cobble occurred relatively frequently and boulders and bedrock were present at a lesser degree. Sediment supply was high with streambanks consisting of loam textures.

Representative Cross Section

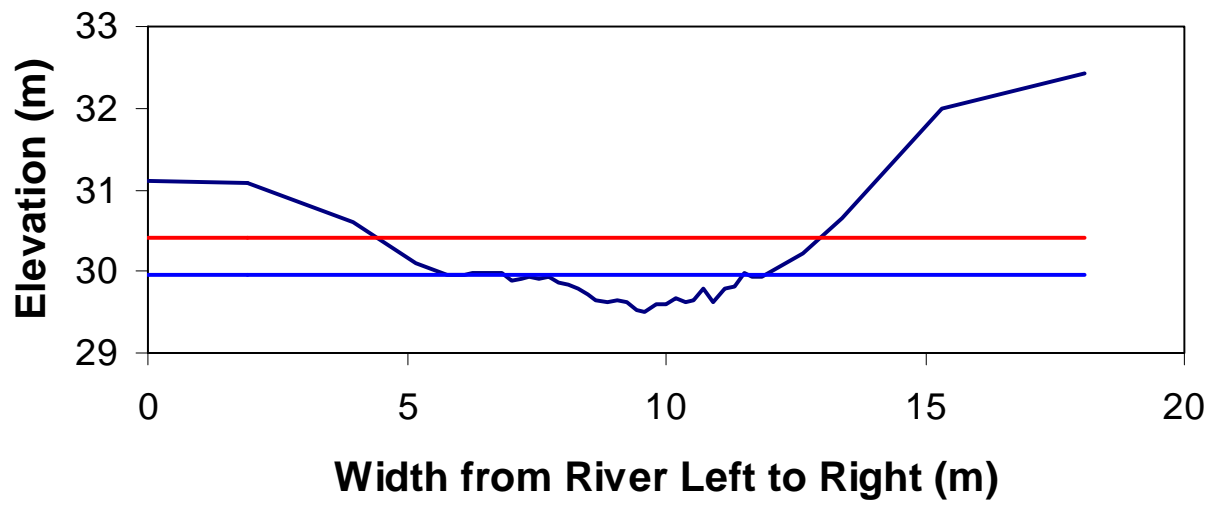




\section{Sediment Characteristics}

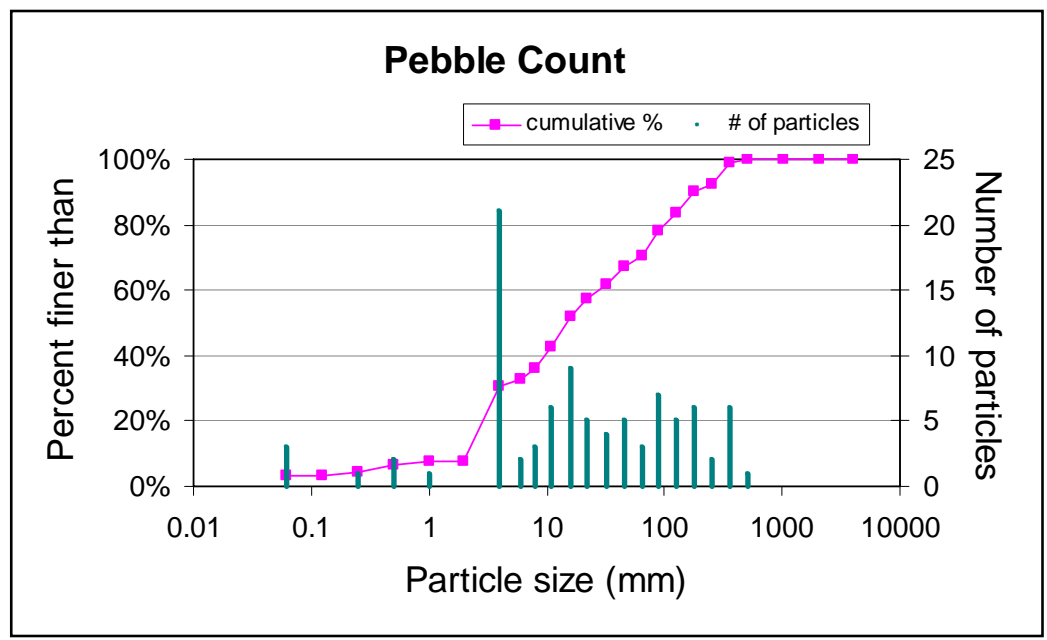

Size Percent Less than (mm): Based on sediment particles only

\begin{tabular}{cccccc}
\hline D16 & D35 & D50 & D65 & D84 & D95 \\
\hline 2.6 & 7.4 & 14.7 & 39 & 130 & 294 \\
\hline Silt/Clay & Sand & Gravel & Cobble & Boulder & Bedrock \\
\hline $3 \%$ & $4 \%$ & $58 \%$ & $20 \%$ & $7 \%$ & $8 \%$ \\
\hline
\end{tabular}

\section{Soil Characteristics}

Right Bank

Texture: Loam

Aggregate Stability: $38.2 \%$

LOI Organic Matter: 9.7\%

H202 Organic Matter: 5.80\%

Rock Fragments: 20\%

K Factor: 0.24

LS Factor: 7.8

C:N Ratio: 1:0.02

pH: 3.86
Left Bank

Texture: Loam

Aggregate Stability: 29.6\%

LOI Organic Matter: $10.95 \%$

H202 Organic Matter: 4.75\%

Rock Fragments: 10\%

K Factor: 0.25

LS Factor: 5.0

C:N Ratio: 1:0.02

pH: 3.28

\begin{tabular}{|c|c|c|c|c|c|c|c|c|c|c|}
\hline \multicolumn{11}{|c|}{ Particle Size (3A1) } \\
\hline \multicolumn{6}{|c|}{ Total (mm) } & \multicolumn{5}{|c|}{ Sand (mm) } \\
\hline $\begin{array}{c}\text { Steam } \\
\text { Bank }\end{array}$ & $\begin{array}{c}\text { Clay } \\
(<.002)\end{array}$ & $\begin{array}{c}\text { Fine silt } \\
(.02-.002)\end{array}$ & $\begin{array}{c}\text { Coarse } \\
\text { Silt } \\
(.05-.02)\end{array}$ & $\begin{array}{l}\text { Total Silt } \\
(.05-.002)\end{array}$ & $\begin{array}{l}\text { Sand } \\
(2-.05)\end{array}$ & $\begin{array}{c}\text { Very } \\
\text { Coarse } \\
(2.0-1.0)\end{array}$ & $\begin{array}{c}\text { Coarse } \\
(1.0-5)\end{array}$ & $\underset{(.5-.25)}{\text { Medium }}$ & $\begin{array}{l}\text { Fine } \\
(.25-.1)\end{array}$ & $\begin{array}{c}\text { Very } \\
\text { Fine } \\
(.1-.05)\end{array}$ \\
\hline Right & 19.58 & 24.15 & 19.69 & 43.84 & 36.58 & 0.27 & 0.45 & 0.56 & 0.89 & 1.15 \\
\hline Left & 17.05 & 24.47 & 17.51 & 41.98 & 40.97 & 0.62 & 0.68 & 0.70 & 0.89 & 0.93 \\
\hline
\end{tabular}




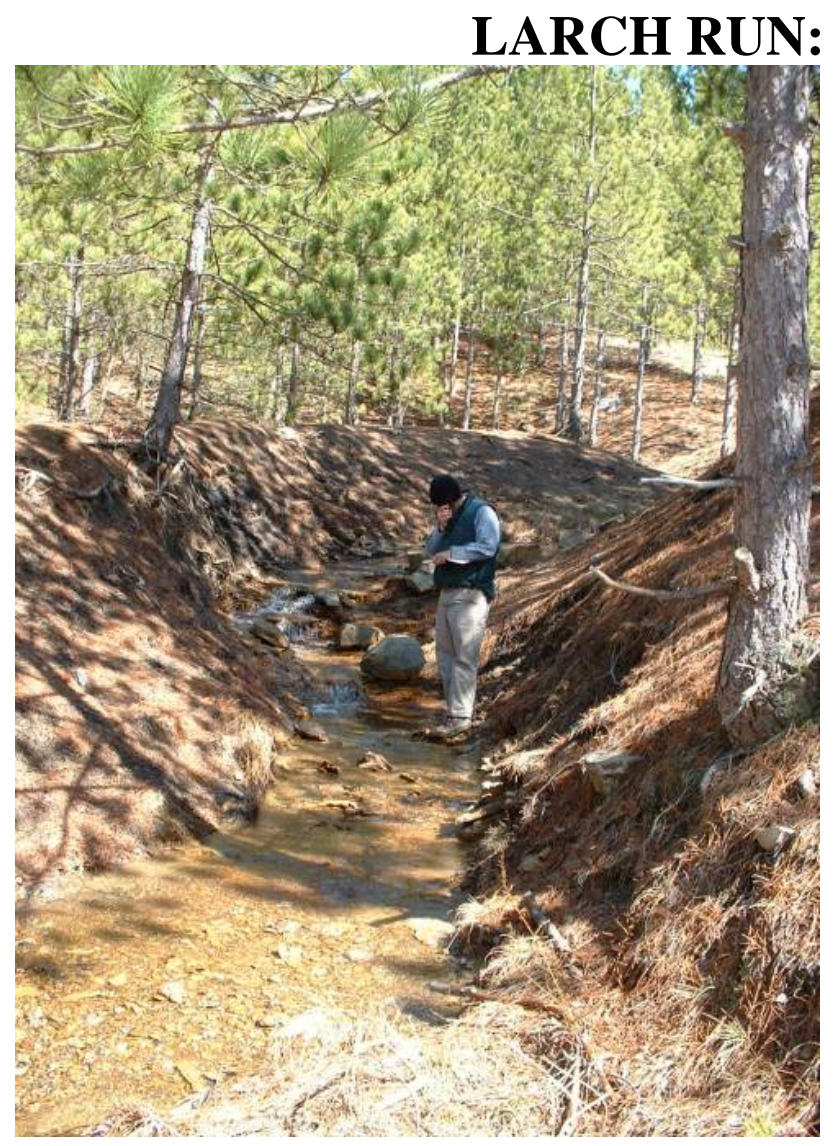

REACH FIVE

Profile Characteristics

Bankfull stage width: $1.9 \mathrm{~m}$

Mean bankfull stage depth: $0.1 \mathrm{~m}$

Mean bank height: $2.6 \mathrm{~m}$

Bank slope angle: $56^{\circ}$

Pool to riffle ratio: $1: 3$

Channel gradient: $3.87 \%$

\section{Morphological Relationships}

Width to depth ratio: 17.4

Entrenchment: 1.6

Sinuosity: 1.12

Bank height/bankfull stage height: 19

Rooting depth/bank height: 0.03

BEHI Rating: 35.1 (High)

\section{Hydraulic Characteristics}

Bankfull discharge (3yr): 173.38 l/s

Bankfull discharge (1.5yr): $109.54 \mathrm{l} / \mathrm{s}$

Stream power (3yr): $1.42 \mathrm{~kg}^{3} / \mathrm{m} / \mathrm{s}$

Stream power (1.5yr): $0.89 \mathrm{~kg}^{3} / \mathrm{m} / \mathrm{s}$

\section{Upstream View}

Vegetation Characteristics: Vegetation covered about 25\% of the channel banks. Primary plant species were red pines and grasses.

Channel Description: Moderately entrenched with a moderate gradient. Dominant channel materials were bedrock, while gravel occurs relatively frequently throughout the channel. Streambanks consisted of loam textures. The right bank has been leveled by an old road bed.

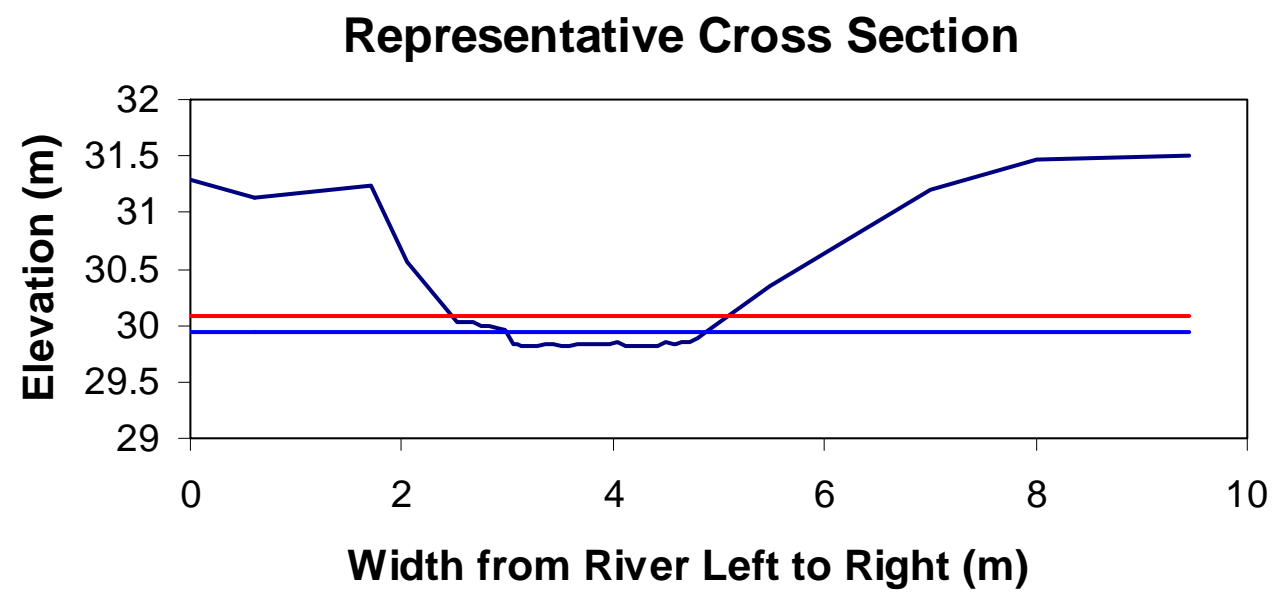




\section{Sediment Characteristics}

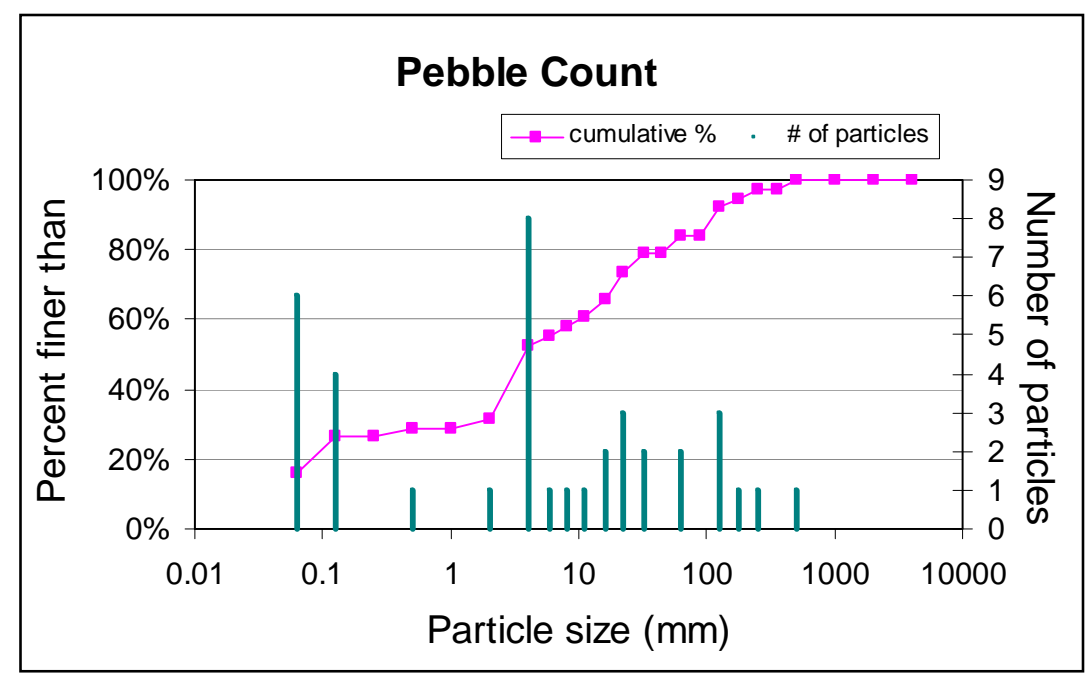

Size Percent Less than (mm): Based on sediment particles only

\begin{tabular}{cccccc}
\hline D16 & D35 & D50 & D65 & D84 & D95 \\
\hline 0.06 & 2.2 & 3.7 & 15 & 63 & 186 \\
\hline
\end{tabular}

Percent by Substrate Type: Based on total count

\begin{tabular}{cccccc}
\hline Silt/Clay & Sand & Gravel & Cobble & Boulder & Bedrock \\
\hline $6 \%$ & $6 \%$ & $20 \%$ & $5 \%$ & $1 \%$ & $62 \%$ \\
\hline
\end{tabular}

\section{$\underline{\text { Soil Characteristics }}$}

Right Bank

Texture: Loam

Aggregate Stability: $6.8 \%$

LOI Organic Matter: 6.56\%

H202 Organic Matter: 3.15\%

Rock Fragments: $70 \%$

K Factor: 0.28

LS Factor: 8.1

C:N Ratio: 1:0.02

pH: 3.27

\section{Left Bank}

Texture: Loam

Aggregate Stability: $47.4 \%$

LOI Organic Matter: $12.7 \%$

H202 Organic Matter: 5.2\%

Rock Fragments: 5\%

K Factor: 0.25

LS Factor: 5.2

C:N Ratio: 1:0.02

pH: 3.28

\begin{tabular}{|c|c|c|c|c|c|c|c|c|c|c|}
\hline \multicolumn{11}{|c|}{ Particle Size (3A1) } \\
\hline \multicolumn{6}{|c|}{ Total (mm) } & \multicolumn{5}{|c|}{ Sand (mm) } \\
\hline $\begin{array}{c}\text { Steam } \\
\text { Bank }\end{array}$ & $\begin{array}{c}\text { Clay } \\
(<.002)\end{array}$ & $\begin{array}{l}\text { Fine silt } \\
(.02-.002)\end{array}$ & \begin{tabular}{|c|} 
Coarse \\
Silt \\
$(.05-.02)$ \\
\end{tabular} & $\begin{array}{l}\text { Total Silt } \\
(.05-.002)\end{array}$ & $\begin{array}{l}\text { Sand } \\
(2-.05)\end{array}$ & $\begin{array}{c}\text { Very } \\
\text { Coarse } \\
(2.0-1.0)\end{array}$ & $\begin{array}{c}\text { Coarse } \\
(1.0-5) \\
\end{array}$ & $\begin{array}{c}\text { Medium } \\
(.5-.25)\end{array}$ & $\begin{array}{c}\text { Fine } \\
(.25-.1)\end{array}$ & $\begin{array}{c}\text { Very } \\
\text { Fine } \\
(.1-.05)\end{array}$ \\
\hline Right & 16.72 & 28.18 & 18.26 & 46.45 & 36.83 & 0.47 & 0.44 & 0.38 & 0.7 & 1.47 \\
\hline Left & 18.21 & 26.45 & 18.00 & 44.45 & 37.34 & 0.19 & 0.40 & 0.65 & 1.03 & 1.13 \\
\hline
\end{tabular}




\section{LARCH RUN: REACH SIX}

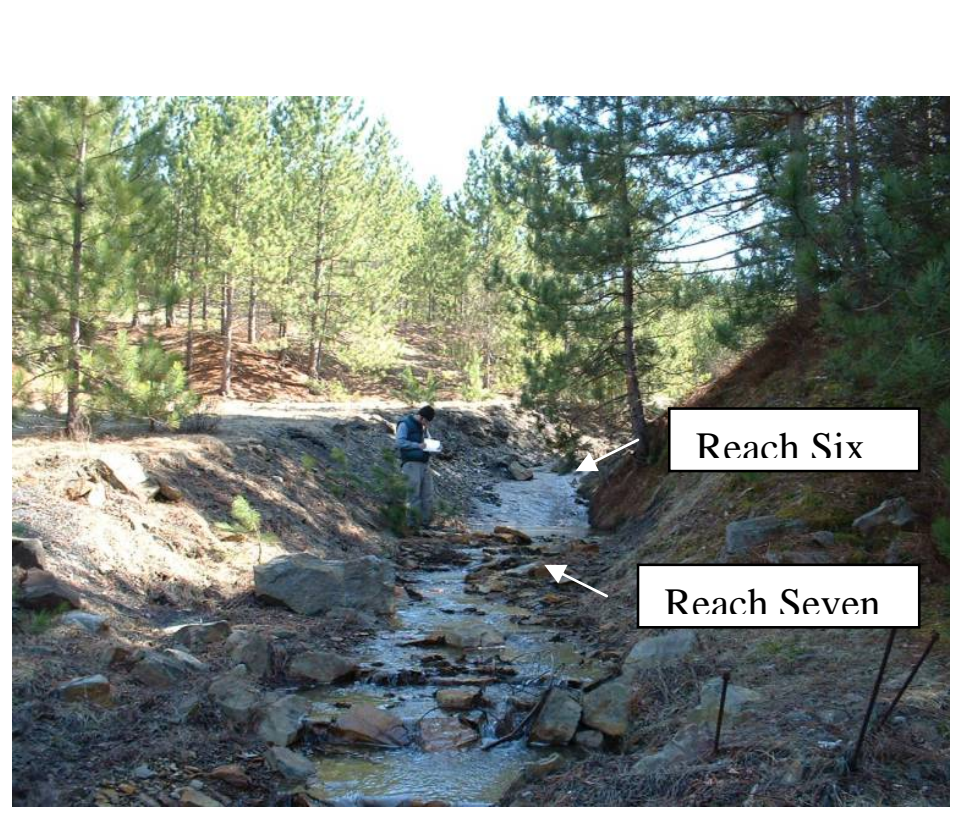

Upstream View
Profile Characteristics

Bankfull stage width: $1.9 \mathrm{~m}$

Mean bankfull stage depth: $0.1 \mathrm{~m}$

Mean bank height: $4.6 \mathrm{~m}$

Bank slope angle: $59^{\circ}$

Pool to riffle ratio: $1: 8$

Channel gradient: $6.9 \%$

\section{Morphological Relationships}

Width to depth ratio: 41.6

Entrenchment: 1.0

Sinuosity: 1.10

Bank height/bankfull stage height: 39

Rooting depth/bank height: 0.03

BEHI Rating: 35.5 (High)

\section{Hydraulic Characteristics}

Bankfull discharge (3yr): $178.60 \mathrm{l} / \mathrm{s}$

Bankfull discharge (1.5yr): $112.82 \mathrm{l} / \mathrm{s}$

Stream power (3yr): $2.80 \mathrm{~kg}^{3} / \mathrm{m} / \mathrm{s}$

Stream power (1.5yr): $1.77 \mathrm{~kg}^{3} / \mathrm{m} / \mathrm{s}$

Vegetation Characteristics: Vegetation covered about 28\% of the channel banks. Red pines with sparse ground cover dominated the left bank. The right bank consisted of red pines and had good ground cover, primarily grasses with some ground pine.

Channel Description: Entrenched with a steep gradient. The dominant channel materials were bedrock with gravel occurring relatively frequently throughout the channel. Streambanks consisted of loam and clay loam textures. The right bank was leveled by an old road bed.
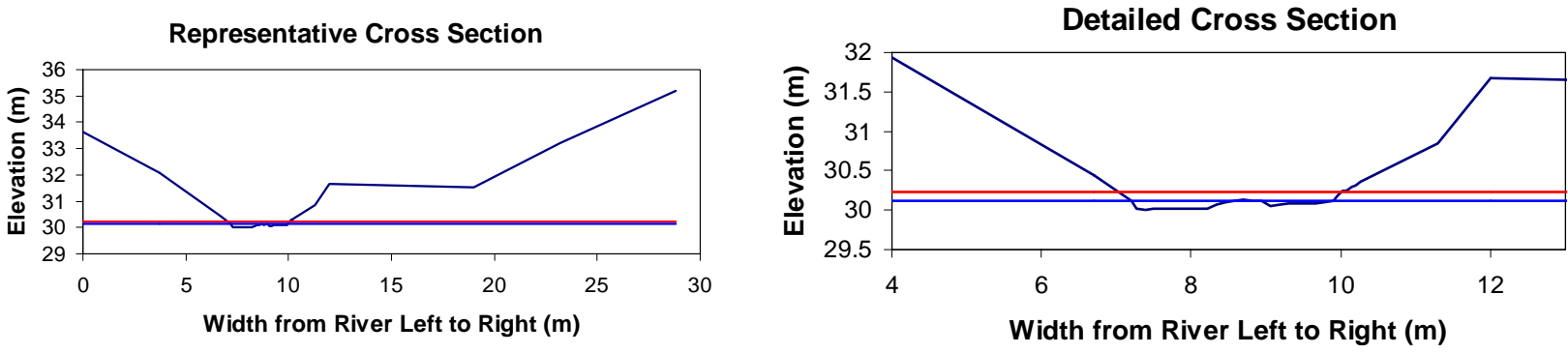


\section{Sediment Characteristics}

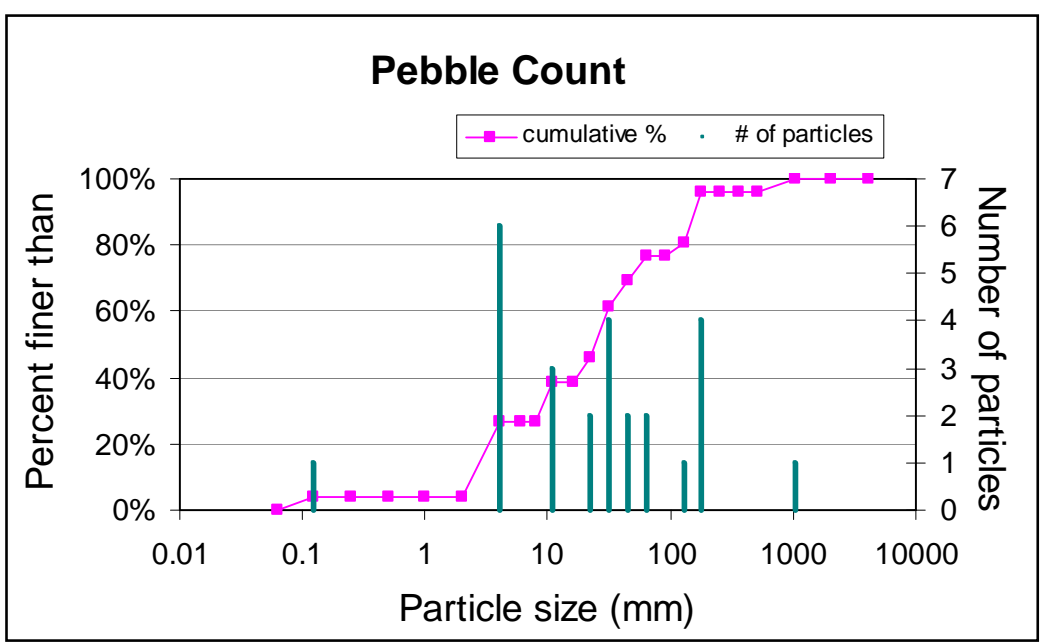

Size Percent Less than (mm): Based on sediment particles only

\begin{tabular}{clllll}
\hline D16 & D35 & D50 & D65 & D84 & D95 \\
\hline 2.9 & 10 & 24.2 & 37 & 138 & 175 \\
\hline \multicolumn{7}{c}{ Percent by } & Substrate Type: Based on total count & \\
\hline Silt/Clay & Sand & Gravel & Cobble & Boulder & Bedrock \\
\hline 0 & $1 \%$ & $19 \%$ & $5 \%$ & $1 \%$ & $74 \%$ \\
\hline
\end{tabular}

\section{Soil Characteristics}

Right Bank

Texture: Loam

Aggregate Stability: 32\%

LOI Organic Matter: $12.3 \%$

H202 Organic Matter: 4.9\%

Rock Fragments: 25\%

K Factor: 0.25

LS Factor: 7.5

C:N Ratio: 1:0.02

$\mathrm{pH}: 4.70$

\section{Left Bank}

Texture: Loam

Aggregate Stability: $19.4 \%$

LOI Organic Matter: 8.2\%

H202 Organic Matter: 5.9\%

Rock Fragments: 35\%

K Factor: 0.21

LS Factor: 12.2

C:N Ratio: 1:0.02

pH: 4.10

\begin{tabular}{|c|c|c|c|c|c|c|c|c|c|c|}
\hline \multicolumn{11}{|c|}{ Particle Size (3A1) } \\
\hline \multicolumn{6}{|c|}{ Total (mm) } & \multicolumn{5}{|c|}{ Sand (mm) } \\
\hline $\begin{array}{l}\text { Steam } \\
\text { Bank }\end{array}$ & $\begin{array}{c}\text { Clay } \\
(<.002)\end{array}$ & $\begin{array}{l}\text { Fine silt } \\
(.02-.002)\end{array}$ & $\begin{array}{c}\text { Coarse } \\
\text { Silt } \\
(.05-.02) \\
\end{array}$ & $\begin{array}{l}\text { Total Silt } \\
(.05-.002)\end{array}$ & $\begin{array}{l}\text { Sand } \\
(2-.05)\end{array}$ & $\begin{array}{c}\text { Very } \\
\text { Coarse } \\
(2.0-1.0)\end{array}$ & $\begin{array}{c}\text { Coarse } \\
(1.0-5) \\
\end{array}$ & $\begin{array}{c}\text { Medium } \\
(.5-.25)\end{array}$ & $\begin{array}{c}\text { Fine } \\
(.25-.1)\end{array}$ & $\begin{array}{l}\text { Very } \\
\text { Fine } \\
(.1-.05) \\
\end{array}$ \\
\hline Right & 17.87 & 27.06 & 18.92 & 45.98 & 36.15 & 0.47 & 0.50 & 0.51 & 0.75 & 1.11 \\
\hline Left & 29.24 & 29.98 & 15.50 & 45.47 & 25.29 & 0.28 & 0.23 & 0.30 & 0.64 & 0.84 \\
\hline
\end{tabular}




\section{LARCH RUN: REACH SEVEN}

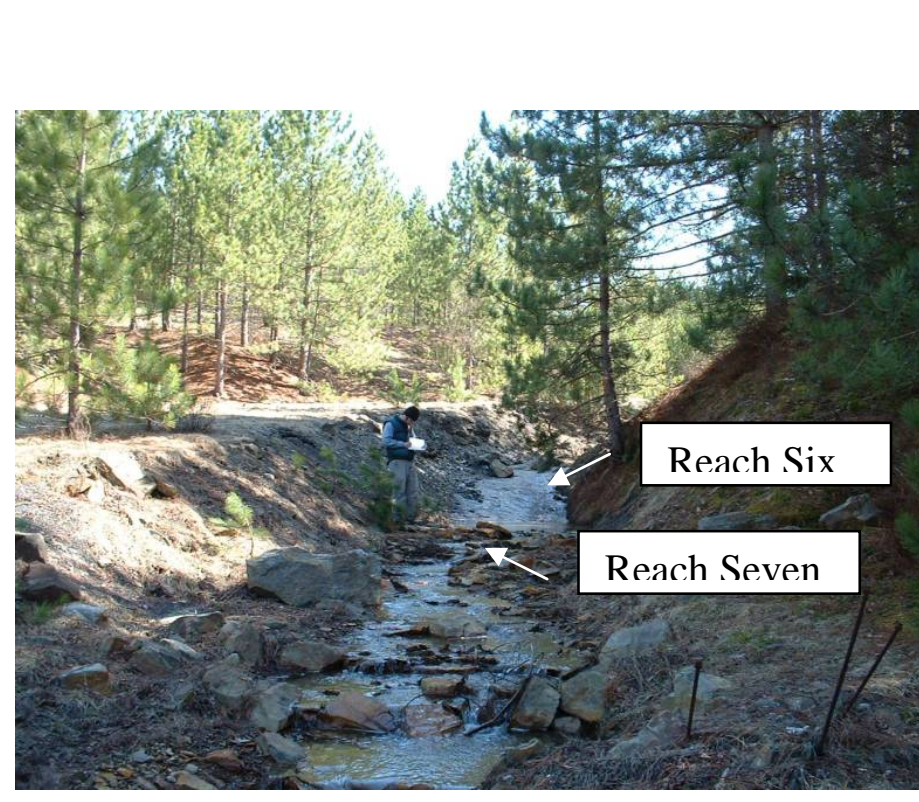

Upstream View
Profile Characteristics

Bankfull stage width: $3.0 \mathrm{~m}$

Mean bankfull stage depth: $0.1 \mathrm{~m}$

Mean bank height: $3.7 \mathrm{~m}$

Bank slope angle: $53^{\circ}$

Pool to riffle ratio: $1: 3.1$

Channel gradient: $5.0 \%$

Morphological Relationships

Width to depth ratio: 25.8

Entrenchment: 1.2

Sinuosity: 1.11

Bank height/bankfull stage height: 13.6

Rooting depth/bank height: 0.03

BEHI Rating: 37.1 (High)

\section{Hydraulic Characteristics}

Bankfull discharge (3yr): 191.22 l/s

Bankfull discharge (1.5yr): $120.73 \mathrm{l} / \mathrm{s}$

Stream power (3yr): $0.75 \mathrm{~kg}^{3} / \mathrm{m} / \mathrm{s}$

Stream power (1.5yr): $0.47 \mathrm{~kg}^{3} / \mathrm{m} / \mathrm{s}$

Vegetation Characteristics: Vegetation covered about 21\% of the channel banks. Red pine, red spruce, and fewer larch were the dominant trees found in this reach. The banks had sparse ground cover consisting of primarily grasses with some lycopodium present. In the downstream portion of the reach, after a large bend, the right bank had good ground cover, consisting of grasses intermingled with dewberries, blueberries, and some lycopodium.

Channel Description: Entrenched with a steep gradient. Dominant channel materials were gravel, while cobble occurred relatively frequently and bedrock was present to a lesser degree. Sediment supply was high with banks consisting of silt loam and loam textures. The right bank was leveled by an old road bed,

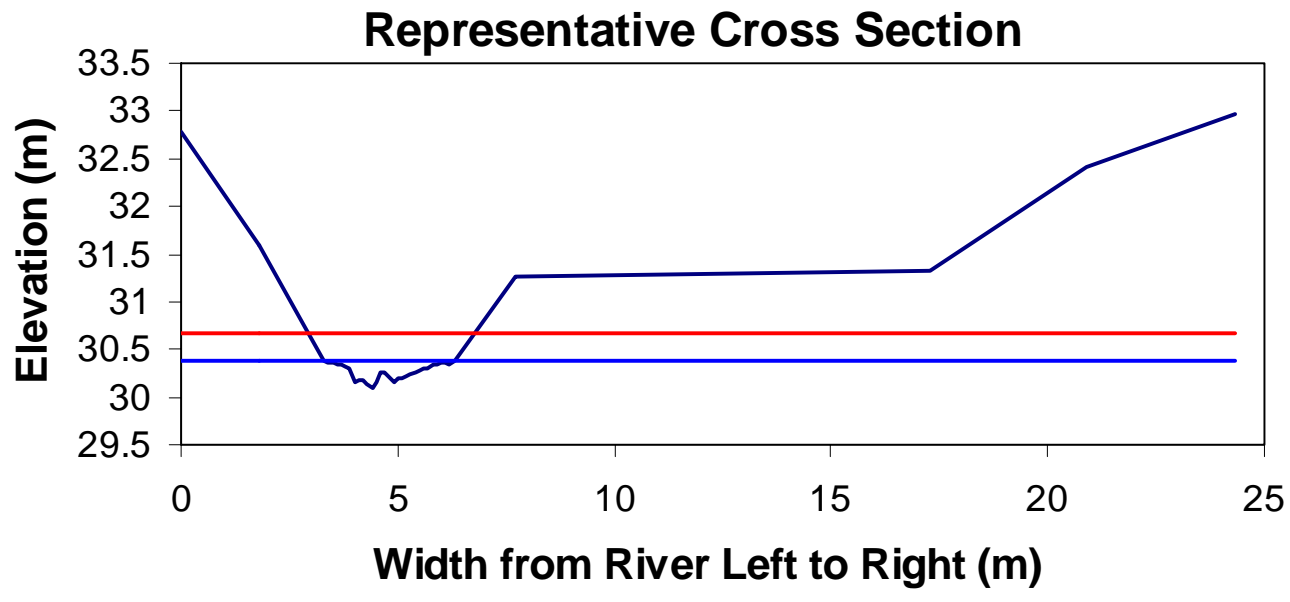




\section{Sediment Characteristics}

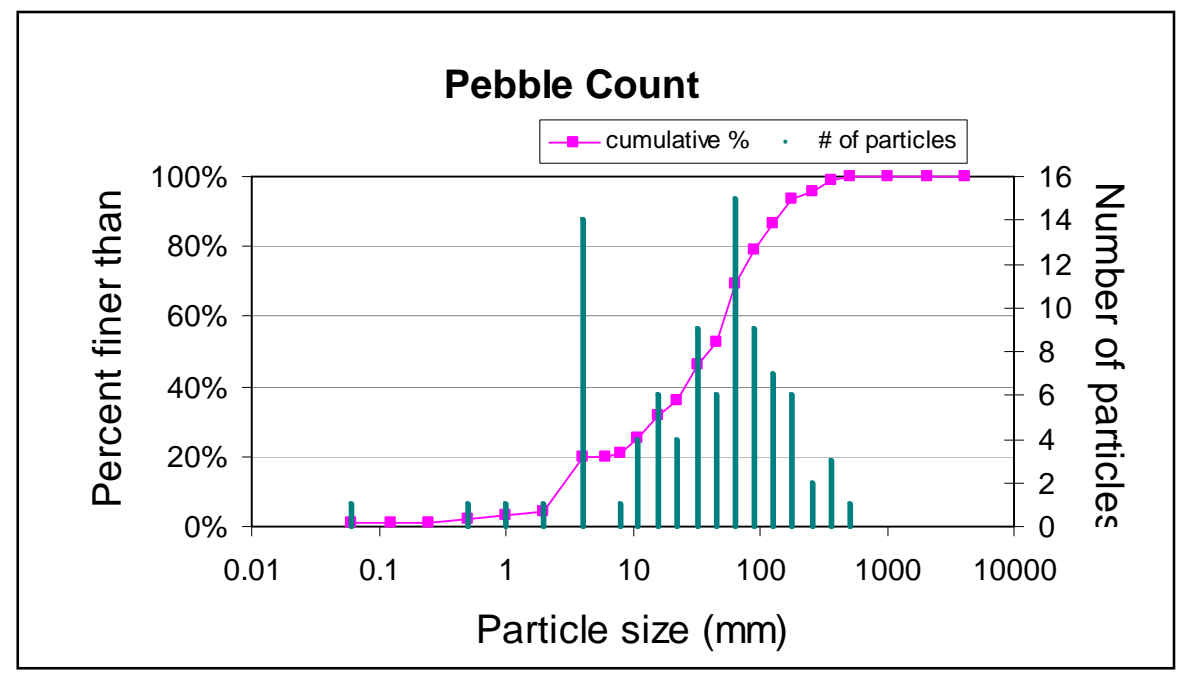

Size Percent Less than (mm): Based on sediment particles only

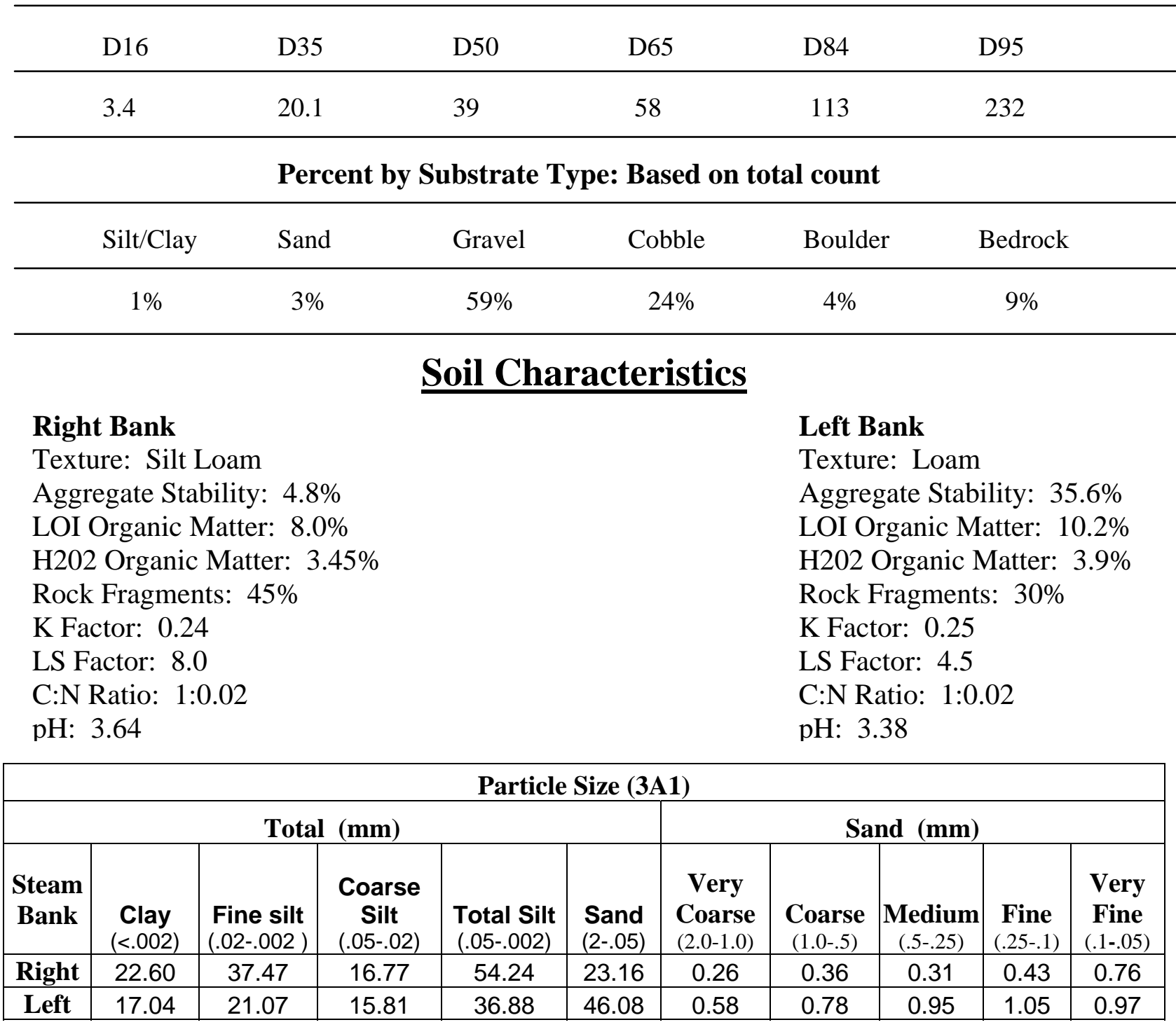




\section{LARCH RUN: REACH EIGHT}

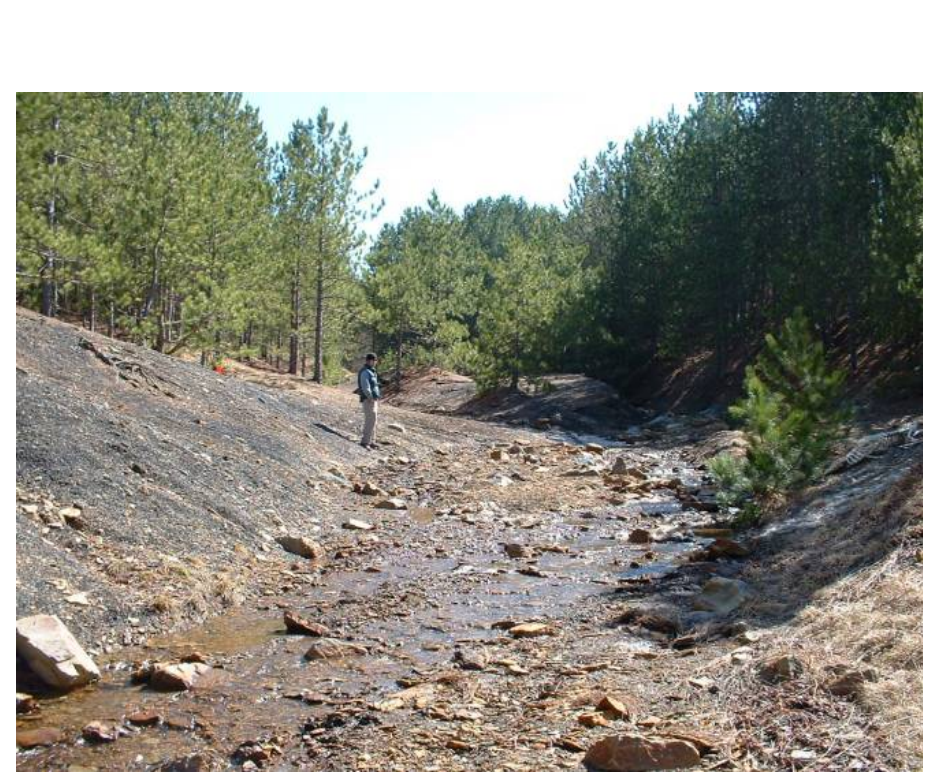

Upstream View
Profile Characteristics

Bankfull stage width: $3.8 \mathrm{~m}$

Mean bankfull stage depth: $0.1 \mathrm{~m}$

Mean bank height: $2.9 \mathrm{~m}$

Bank slope angle: $49^{\circ}$

Pool to riffle ratio: $1: 2.3$

Channel gradient: $2.60 \%$

Morphological Relationships

Width to depth ratio: 30.6

Entrenchment: 1.3

Sinuosity: 1.06

Bank height/bankfull stage height: 13

Rooting depth/bank height: 0.04

BEHI Rating: 36.8 (High)

\section{Hydraulic Characteristics}

Bankfull discharge (3yr): 198.15 l/s

Bankfull discharge (1.5yr): $125.08 \mathrm{l} / \mathrm{s}$

Stream power (3yr): $0.68 \mathrm{~kg}^{3} / \mathrm{m} / \mathrm{s}$

Stream power (1.5yr): $0.43 \mathrm{~kg}^{3} / \mathrm{m} / \mathrm{s}$

Vegetation Characteristics: Vegetation covered 28\% of the channel banks. Dominant vegetation consisted primarily of grasses with an occasional red pine.

Channel Description: Entrenched channel with a gentle slope. Dominant channel materials were gravel, while cobble occurred less frequently. Streambanks consisted of sandy loam and loam textures.

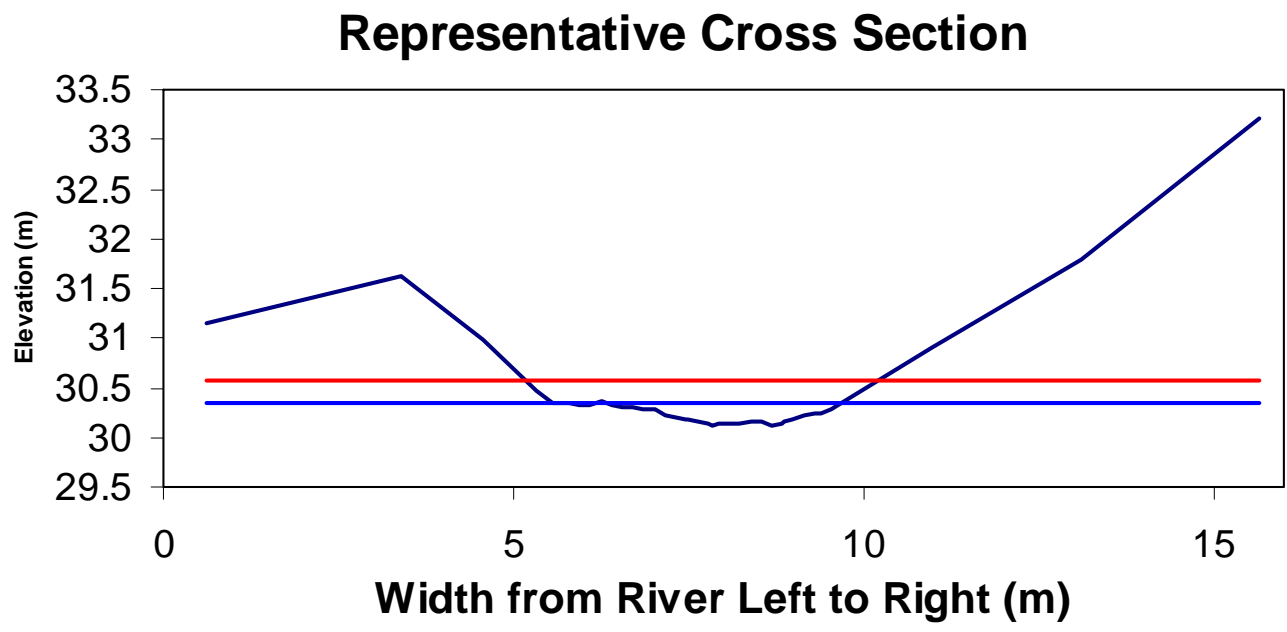




\section{Sediment Characteristics}

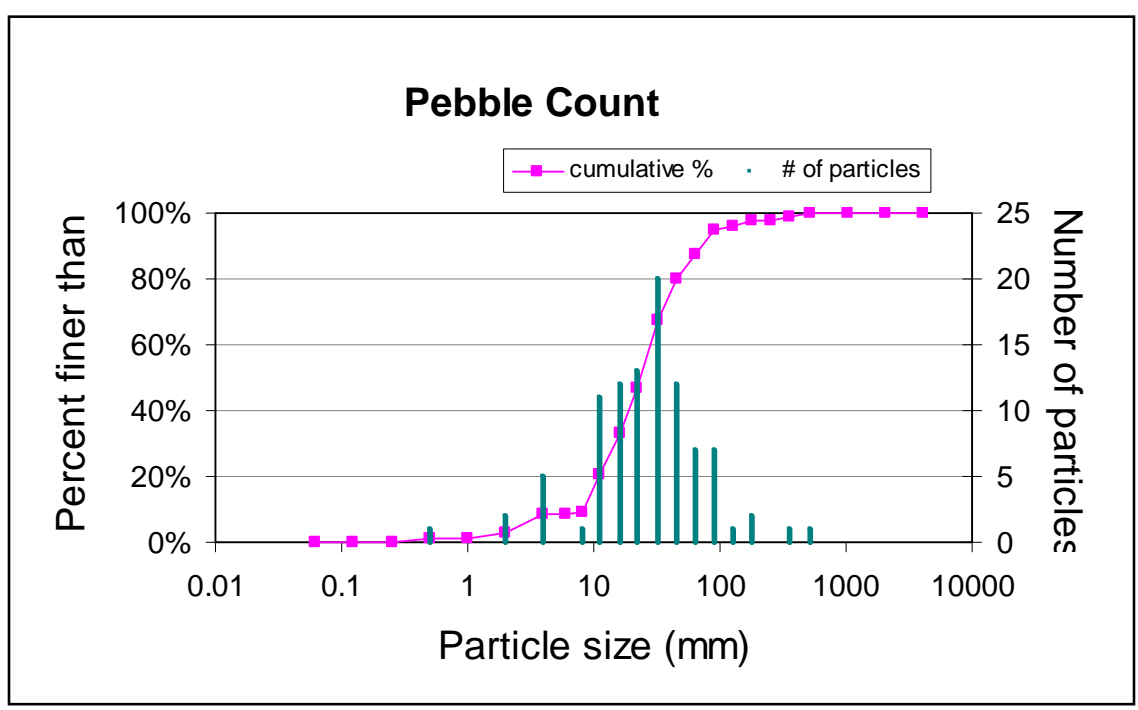

Size Percent Less than (mm): Based on sediment particles only

\begin{tabular}{cccccc}
\hline D16 & D35 & D50 & D65 & D84 & D95 \\
\hline 9.6 & 16.6 & 23.3 & 30 & 54 & 97 \\
\hline & Percent by & Substrate Type: & Based on total count & \\
\hline Silt/Clay & Sand & Gravel & Cobble & Boulder & Bedrock \\
\hline $0 \%$ & $3 \%$ & $81 \%$ & $10 \%$ & $2 \%$ & $4 \%$ \\
\hline
\end{tabular}

\section{$\underline{\text { Soil Characteristics }}$}

Right Bank

Texture: Sandy Loam

Aggregate Stability: $5.8 \%$

LOI Organic Matter: 6.6\%

H202 Organic Matter: 4.5\%

Rock Fragments: 70\%

K Factor: 0.24

LS Factor: 5.6

C:N Ratio: 1:0.02

pH: 5.70
Left Bank

Texture: Loam

Aggregate Stability: $22.0 \%$

LOI Organic Matter: $10.2 \%$

H202 Organic Matter: 4.6\%

Rock Fragments: 15\%

K Factor: 0.24

LS Factor: 4.2

C:N Ratio: 1:0.02

pH: 3.40

\begin{tabular}{|c|c|c|c|c|c|c|c|c|c|c|}
\hline \multicolumn{11}{|c|}{ Particle Size (3A1) } \\
\hline \multicolumn{6}{|c|}{ Total (mm) } & \multicolumn{5}{|c|}{ Sand (mm) } \\
\hline $\begin{array}{l}\text { Steam } \\
\text { Bank }\end{array}$ & $\begin{array}{c}\text { Clay } \\
(<.002)\end{array}$ & $\begin{array}{l}\text { Fine silt } \\
(.02-.002)\end{array}$ & $\begin{array}{c}\text { Coarse } \\
\text { Silt } \\
(.05-.02)\end{array}$ & $\begin{array}{l}\text { Total Silt } \\
(.05-.002)\end{array}$ & $\begin{array}{l}\text { Sand } \\
(2-.05)\end{array}$ & $\begin{array}{l}\text { Very } \\
\text { Coarse } \\
(2.0-1.0)\end{array}$ & $\begin{array}{c}\text { Coarse } \\
(1.0-.5) \\
\end{array}$ & $\begin{array}{c}\text { Medium } \\
(.5-.25)\end{array}$ & $\begin{array}{c}\text { Fine } \\
(.25-.1)\end{array}$ & $\begin{array}{c}\text { Very } \\
\text { Fine } \\
(.1-.05) \\
\end{array}$ \\
\hline Right & 18.24 & 18.77 & 7.23 & 26.00 & 55.76 & 1.54 & 1.65 & 1.08 & 0.61 & 0.33 \\
\hline Left & 20.75 & 20.77 & 14.61 & 35.38 & 43.87 & 0.62 & 0.87 & 0.97 & 0.95 & 0.85 \\
\hline
\end{tabular}




\section{SLATY FORK}

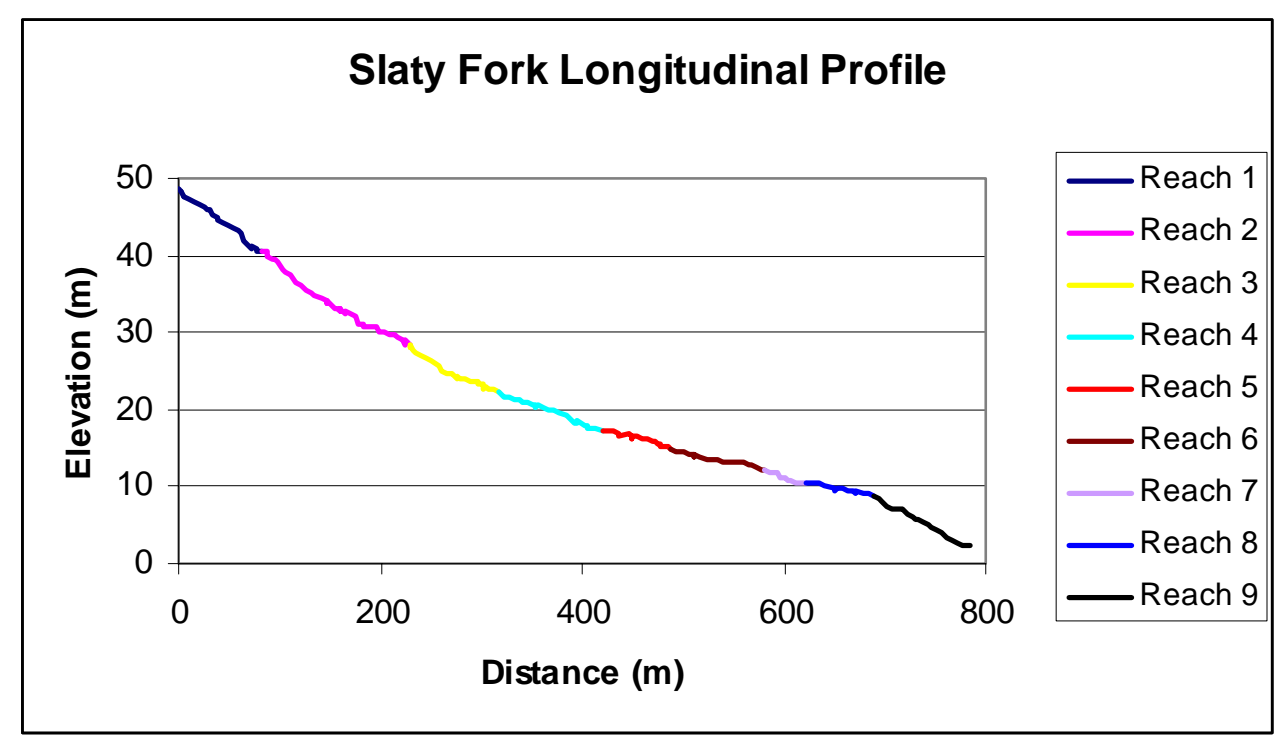

Site Location: Where stream surveying began

Latitude: $39^{\circ} 09^{\prime} 14.8^{\prime \prime}$ N

Longitude: $79^{\circ} 25^{\prime} 13.3^{\prime \prime}$ ' W

Drainage area: $155,221 \mathrm{~m}^{2}$

Stream Description: Slaty Fork was the largest of the three streams and had characteristics similar to Larch Run. This stream was comprised of nine reaches: four aggrading, one transitional, and three bedrock. Bank failures were common throughout this tributary.

Relationships below were determined by averaging values from reaches.

Profile Characteristics

Mean bankfull stage width: $3.54 \mathrm{~m}$

Mean bank height: $3.16 \mathrm{~m}$

Mean bank slope angle: $52^{\circ}$

Mean pool to riffle ratio: $1: 4.5$

Total channel gradient: $5.55 \%$

\section{Morphological Relationships}

Mean width to depth ratio: 25.99

Mean entrenchment ratio: 1.78

Total Sinuosity: 1.25

Total BEHI rating: 34.32 (High)

Hydraulic Characteristics

Measn bankfull discharge (3yr): 164.72 l/s

Mean bankfull discharge (1.5yr): 104.08 l/s

Mean stream power (3yr): $1.55 \mathrm{~kg}^{3} / \mathrm{m} / \mathrm{s}$

Mean stream power (1.5yr): $0.98 \mathrm{~kg}^{3} / \mathrm{m} / \mathrm{s}$ 


\section{SLATY FORK: REACH ONE}

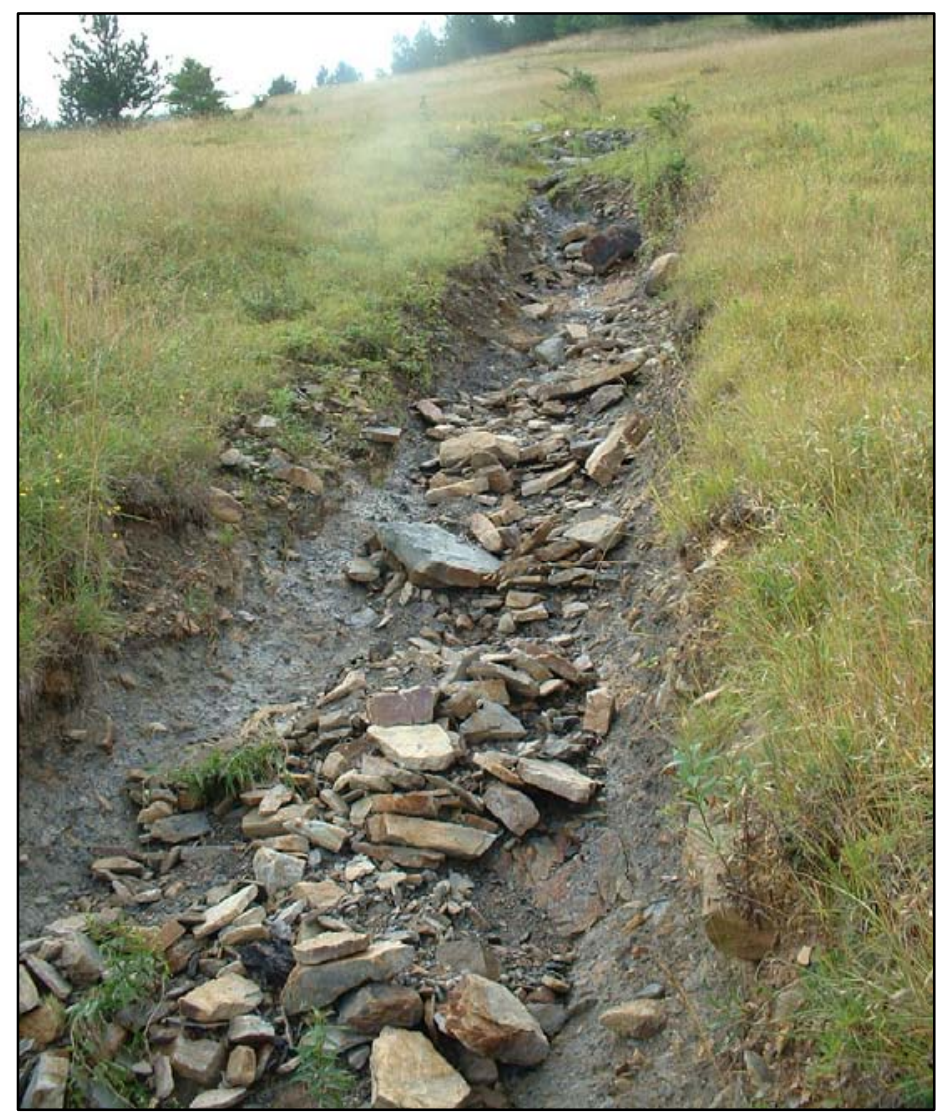

\section{Profile Characteristics}

Bankfull stage width: $1.5 \mathrm{~m}$

Mean bankfull stage depth: $.03 \mathrm{~m}$

Mean Bank Height: $1.1 \mathrm{~m}$

Bank slope angle: $65^{\circ}$

Pool to riffle ratio: Not determined

Channel gradient: $9.53 \%$

\section{Morphological Relationships}

Width to depth ratio: 24.2

Entrenchment: 1.4

Sinuosity: 1.12

Bank height/bankfull stage height: 5.0

Rooting depth/bank height: 0.06

BEHI rating: 33.3 (High)

\section{Hydraulic Characteristics}

Bankfull discharge (3yr): $85.25 \mathrm{l} / \mathrm{s}$

Bankfull discharge (1.5yr): $54.09 \mathrm{l} / \mathrm{s}$

Stream power (3yr): $0.40 \mathrm{~kg}^{3} / \mathrm{m} / \mathrm{s}$

Stream power (1.5yr): $0.26 \mathrm{~kg}^{3} / \mathrm{m} / \mathrm{s}$

\section{Upstream View}

Vegetation Characteristics: Vegetation covered about 43\% of the channel banks. Dominant vegetation consisted of primarily of grasses, while dewberry and autumn olive occurred less frequently. Dear tongue was found occasionally in the streambed.

Channel Description: Moderately entrenched channel with a very steep gradient. Dominant channel materials were gravel, while cobble and sand occurred relatively frequently throughout the channel. Streambanks consisted of loam textures.

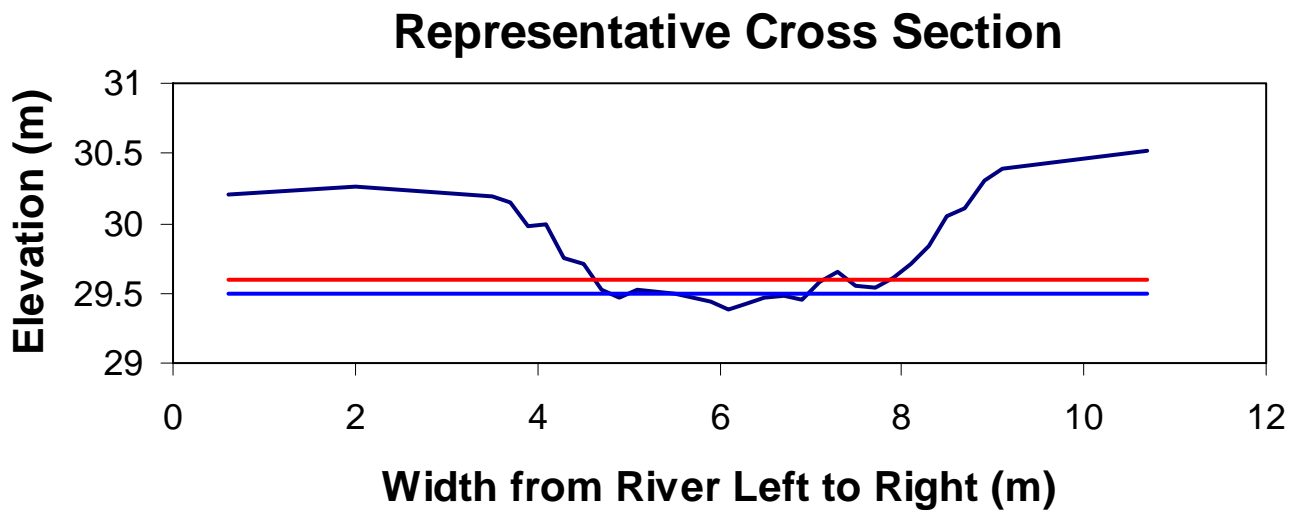




\section{Sediment Characteristics}

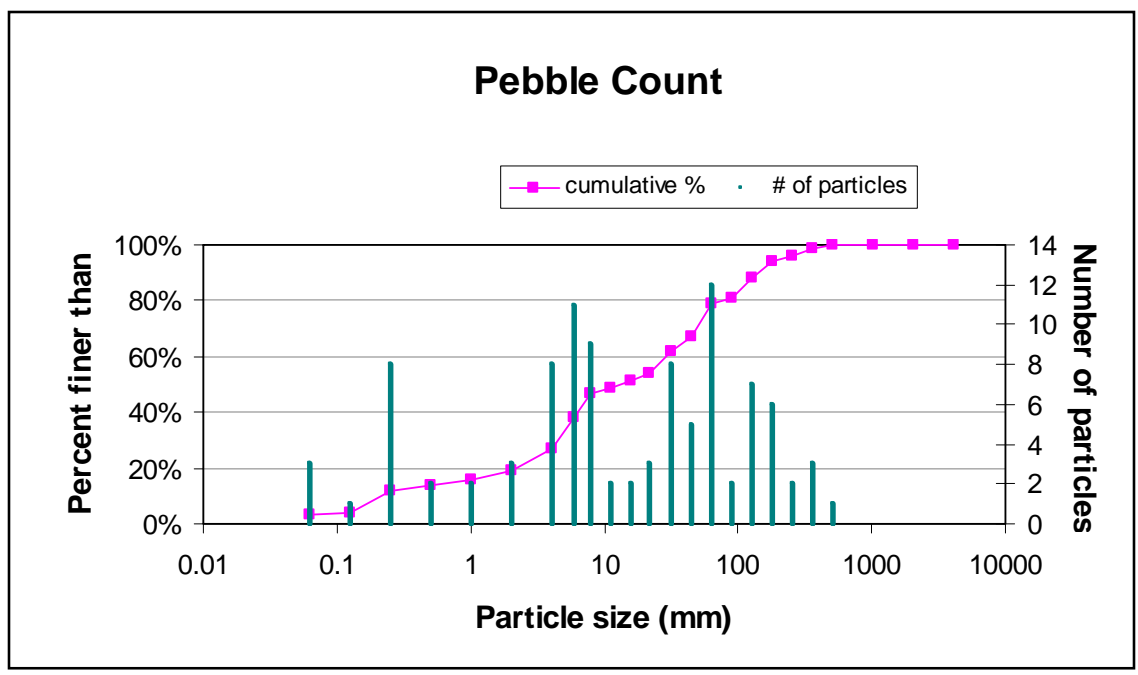

Size Percent Less than (mm): Based on sediment particles only

\begin{tabular}{clllll}
\hline D16 & D35 & D50 & D65 & D84 & D95 \\
\hline 1.0 & 5.4 & 13.3 & 39 & 105 & 215 \\
\hline Silt/Clay & Sercent by & Substrate Type: Based on total count & \\
\hline 3\% & $16 \%$ & Gravel & Cobble & Boulder & Bedrock \\
\hline
\end{tabular}

\section{Right Bank}

Texture: Silt Loam

Aggregate Stability: 62.5

LOI Organic Matter: 5.66\%

H202 Organic Matter: 2.75\%

Rock Fragments: 2\%

K Factor: .26

LS Factor: 4.6

C:N ratio: 1:0.05

PH: 5.2

\section{Soil Characteristics}

\section{Left Bank}

Texture: Loam

Aggregate Stability: 54.4

LOI Organic Matter: $9.08 \%$

H202 Organic Matter: 5.4\%

Rock Fragments: 3\%

K Factor: 0.22

LS Factor: 6.4

$\mathrm{C}: \mathrm{N}$ ratio: $1: 0.04$

$\mathrm{pH}: 4.03$

\begin{tabular}{|c|c|c|c|c|c|c|c|c|c|c|}
\hline \multicolumn{11}{|c|}{ Particle Size (3A1) } \\
\hline \multicolumn{6}{|c|}{ Total (mm) } & \multicolumn{5}{|c|}{ Sand (mm) } \\
\hline $\begin{array}{c}\text { Steam } \\
\text { Bank }\end{array}$ & $\begin{array}{c}\text { Clay } \\
(<.002)\end{array}$ & $\begin{array}{l}\text { Fine silt } \\
(.02-.002)\end{array}$ & \begin{tabular}{|c} 
Coarse \\
Silt \\
$(.05-.02)$ \\
\end{tabular} & $\begin{array}{l}\text { Total Silt } \\
(.05-.002)\end{array}$ & $\begin{array}{l}\text { Sand } \\
(2-.05)\end{array}$ & $\begin{array}{c}\text { Very } \\
\text { Coarse } \\
(2.0-1.0) \\
\end{array}$ & $\begin{array}{c}\text { Coarse } \\
(1.0-.5) \\
\end{array}$ & $\begin{array}{c}\text { Medium } \\
(.5-.25) \\
\end{array}$ & \begin{tabular}{|c} 
Fine \\
$(.25-.1)$
\end{tabular} & $\begin{array}{c}\text { Very } \\
\text { Fine } \\
(.1-.05) \\
\end{array}$ \\
\hline Right & 21.77 & 31.83 & 20.10 & 51.93 & 26.31 & 0.49 & 0.37 & 0.36 & 0.62 & 0.74 \\
\hline Left & 20.60 & 26.63 & 18.33 & 44.96 & 34.44 & 0.485 & 0.62 & 0.625 & 0.75 & 0.73 \\
\hline
\end{tabular}




\section{SLATY FORK: REACH TWO}

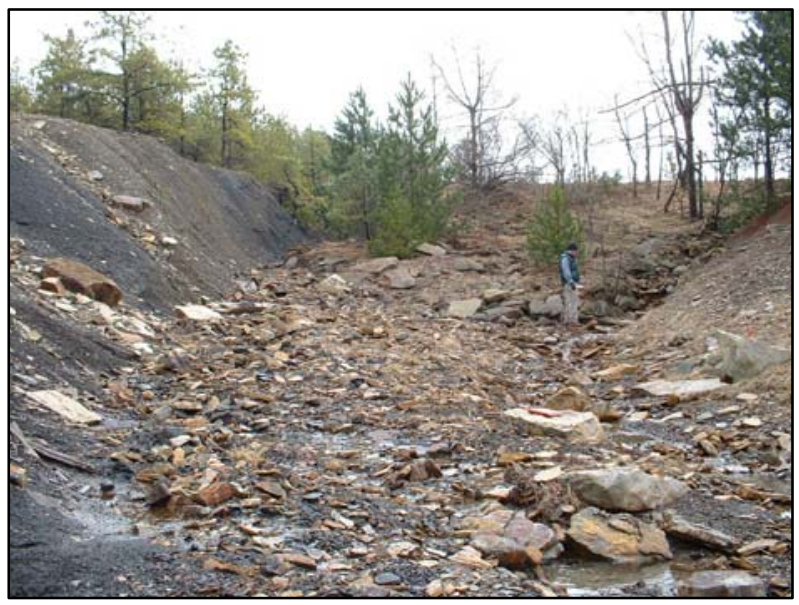

Upstream View

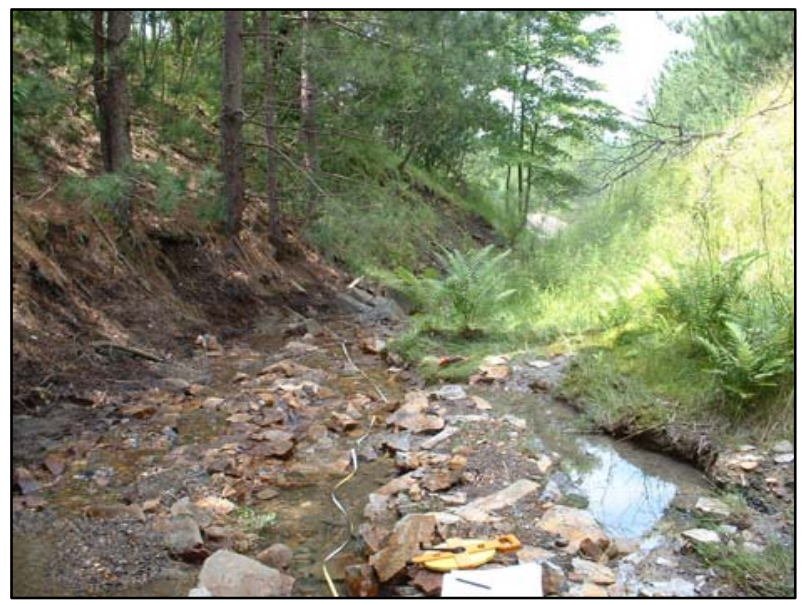

Downstream View

\section{Profile Characteristics}

Bankfull stage width: $1 \mathrm{~m}$

Mean bankfull stage depth: $0.2 \mathrm{~m}$

Mean bank height: $6.2 \mathrm{~m}$

Bank slope angle: $55^{\circ}$

Pool to riffle ratio: $1: 4.2$

Channel gradient: $8.64 \%$
Morphological Relationships

Width to depth ratio: 2.2

Entrenchment: 1.6

Sinuosity: 1.31

BEHI rating: 35.1 (High) Bank height/bankfull stage height: 18

Rooting depth/bank height: 0.01
Hydraulic Characteristics

Bankfull discharge (3yr): $111.76 \mathrm{l} / \mathrm{s}$ Bankfull discharge (1.5yr): $70.79 \mathrm{l} / \mathrm{s}$ Stream power (3yr): $0.68 \mathrm{~kg}^{3} / \mathrm{m} / \mathrm{s}$ Stream power (1.5yr): $0.43 \mathrm{~kg}^{3} / \mathrm{m} / \mathrm{s}$

Vegetation Characteristics: Vegetation covered about 34\% of the channel banks. There was generally no vegetation on the right bank. Grasses, blackberry, lycopodium, quaking aspen, red pine, alder, moss, dewberry, and blueberry were present on the left bank.

Description: Moderately entrenched channel with a very steep channel gradient. Dominant channel materials were gravel and cobble. Sediment supply was high with streambanks consisting of loam textures. Large gulleys were present on banks in the upper portion of the reach where vegetation was sparse.

\section{Representative Cross Section}

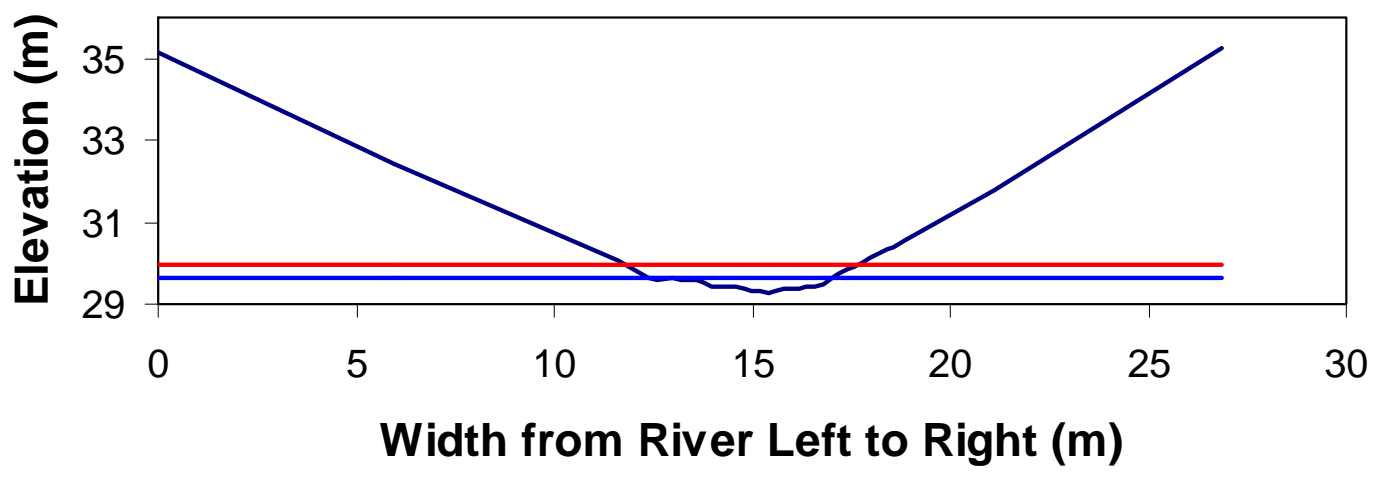




\section{Sediment Characteristics}

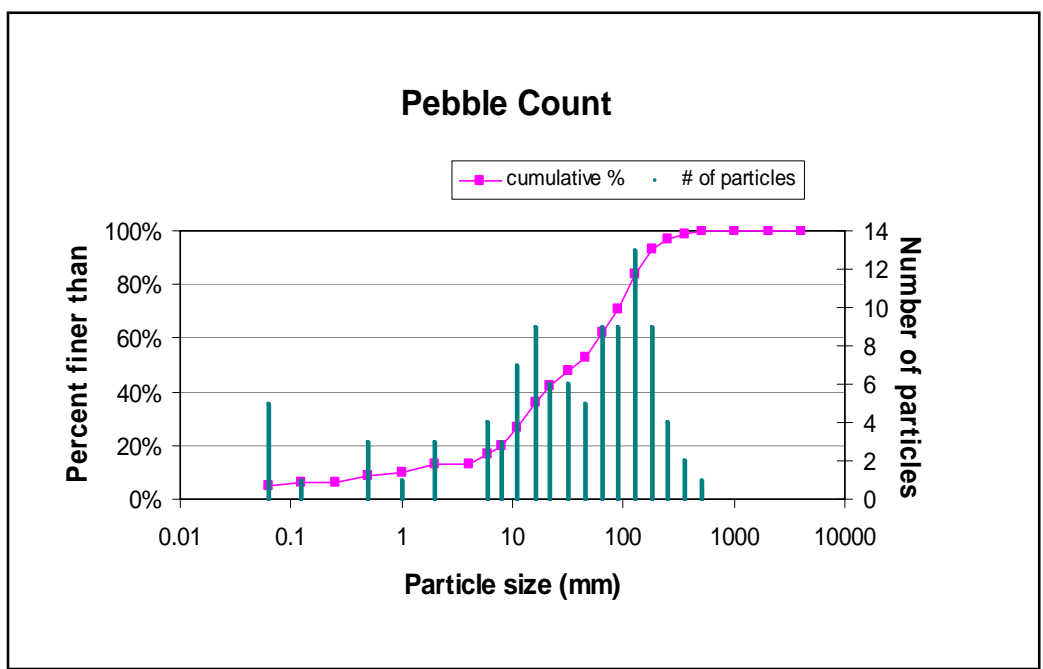

Size Percent Less than (mm): Based on sediment particles only

\begin{tabular}{cccccc}
\hline D16 & D35 & D50 & D65 & D84 & D95 \\
\hline 5.4 & 15.4 & 36.7 & 72 & 128 & 215 \\
\hline Silt/Clay & Sercent by Substrate Type: & Based on total count & \\
\hline $5 \%$ & $8 \%$ & Gravel & Cobble & Boulder & Bedrock \\
\hline
\end{tabular}

\section{Soil Characteristics}

Right Bank

Texture: Loam

Aggregate Stability: $9.8 \%$

LOI Organic Matter: $8.36 \%$

H202 Organic Matter: 2.15\%

Rock Fragments: $75 \%$

K factor: 0.27

LS Factor: 5.1

C:N ratio: $1: 0.03$

$\mathrm{pH}: 2.86$
Right Bank (Seep)

Texture: Silty Clay Loam

Aggregate Stability: 13\%

LOI Organic Matter: 9.86\%

H202 Organic Matter: 4.15\%

Rock Fragments: 30\%

K Factor: 0.2

LS Factor: 5.1

C:N ratio: 1:0.02

pH: 3.56

\section{Left Bank}

Texture: Loam

Aggregate Stability: $32.6 \%$

LOI Organic Matter: 9.81\%

H202 Organic Matter: 4.95\%

Rock Fragments: 10\%

K Factor: 0.24

LS Factor: 7.3

C:N ratio: 1:0.02

$\mathrm{pH}: 3.35$

\begin{tabular}{|c|c|c|c|c|c|c|c|c|c|c|}
\hline \multicolumn{11}{|c|}{ Particle Size (3A1) } \\
\hline \multicolumn{6}{|c|}{ Total (mm) } & \multicolumn{5}{|c|}{ Sand (mm) } \\
\hline $\begin{array}{c}\text { Steam } \\
\text { Bank }\end{array}$ & \begin{tabular}{|c} 
Clay \\
$(<.002)$
\end{tabular} & $\begin{array}{c}\text { Fine silt } \\
(.02-.002)\end{array}$ & $\begin{array}{c}\text { Coarse } \\
\text { Silt } \\
(.05-.02)\end{array}$ & $\begin{array}{l}\text { Total Silt } \\
(.05-.002)\end{array}$ & $\begin{array}{l}\text { Sand } \\
(2-.05)\end{array}$ & $\begin{array}{c}\text { Very } \\
\text { Coarse } \\
(2.0-1.0) \\
\end{array}$ & $\begin{array}{c}\text { Coarse } \\
(1.0-.5) \\
\end{array}$ & $\begin{array}{c}\text { Medium } \\
(.5-.25) \\
\end{array}$ & $\begin{array}{c}\text { Fine } \\
(.25-.1)\end{array}$ & $\begin{array}{c}\text { Very } \\
\text { Fine } \\
(.1-.05) \\
\end{array}$ \\
\hline Right & 17.98 & 27.51 & 10.69 & 43.58 & 43.82 & 0.795 & 0.965 & 0.8 & 0.825 & 0.675 \\
\hline Right (s) & 27.95 & 41.66 & 13.49 & 55.14 & 16.91 & 0.25 & 0.36 & 0.27 & 0.34 & 0.44 \\
\hline Left & 23.17 & 29.58 & 13.72 & 43.31 & 33.53 & 0.56 & 0.56 & 0.61 & 0.79 & 0.84 \\
\hline
\end{tabular}




\section{SLATY FORK: REACH THREE}

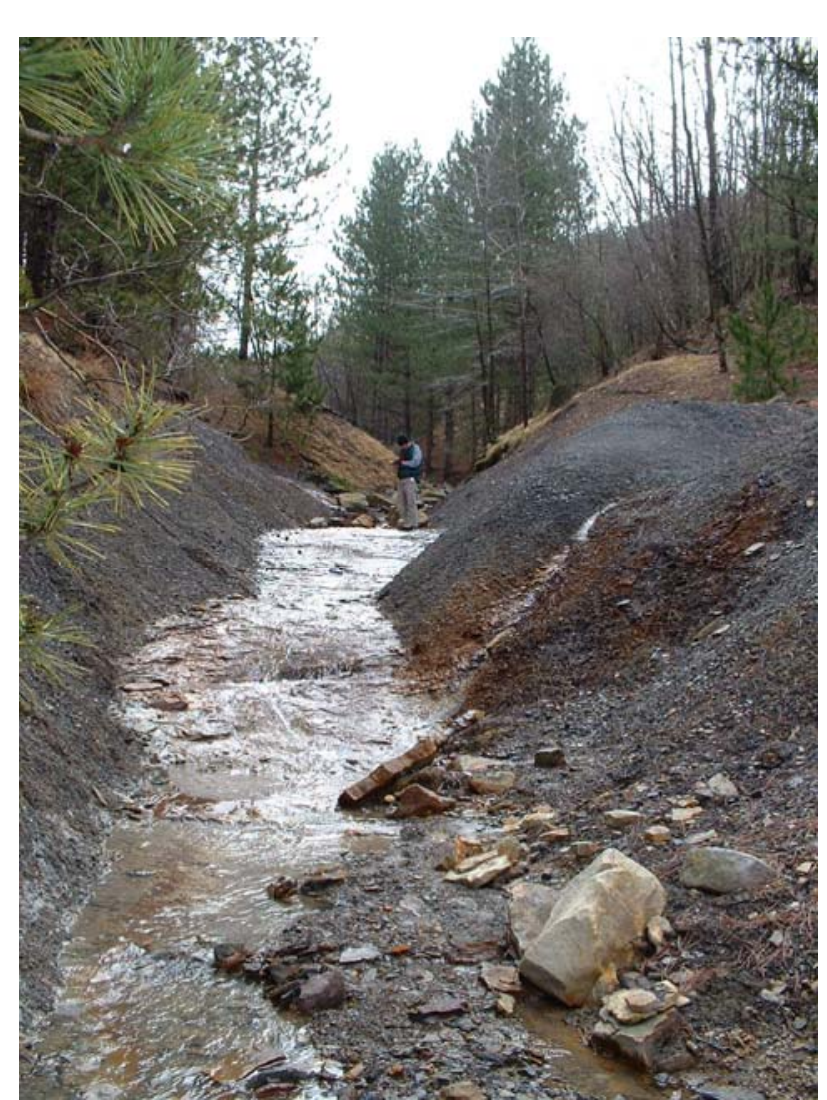

Upstream View

\section{Profile Characteristics}

Bankfull stage width: $1 \mathrm{~m}$

Mean bankfull stage depth: $0.12 \mathrm{~m}$

Mean bank height: $4 \mathrm{~m}$

Bank slope angle: $47^{\circ}$

Pool to riffle ratio: $1: 4.6$

Channel gradient: $6.72 \%$

\section{Morphological Relationships}

Width to depth ratio: 7.8

Entrenchment: 0.3

Sinuosity: 1.07

Bank height/bankfull stage height: 34.2

Rooting depth/bank height: 0.03

BEHI rating: 43.5 (Very High)

\section{Hydraulic Characteristics}

Bankfull discharge (3yr): 137.23 l/s

Bankfull discharge (1.5yr): $86.82 \mathrm{l} / \mathrm{s}$

Stream power (3yr): $1.30 \mathrm{~kg}^{3} / \mathrm{m} / \mathrm{s}$

Stream power (1.5yr): $0.82 \mathrm{~kg}^{3} / \mathrm{m} / \mathrm{s}$

Vegetation Characteristics: Vegetation covered about 3\% of the channel banks. Red pine occurred on the top of the banks at a sparse density

Channel Description: Moderately entrenched channel with a steep slope. Dominant channel materials were bedrock and gravel, while cobble occurred less frequently. Streambanks consisted of silty clay loam and silty clay textures.

\section{Representative Cross Section}

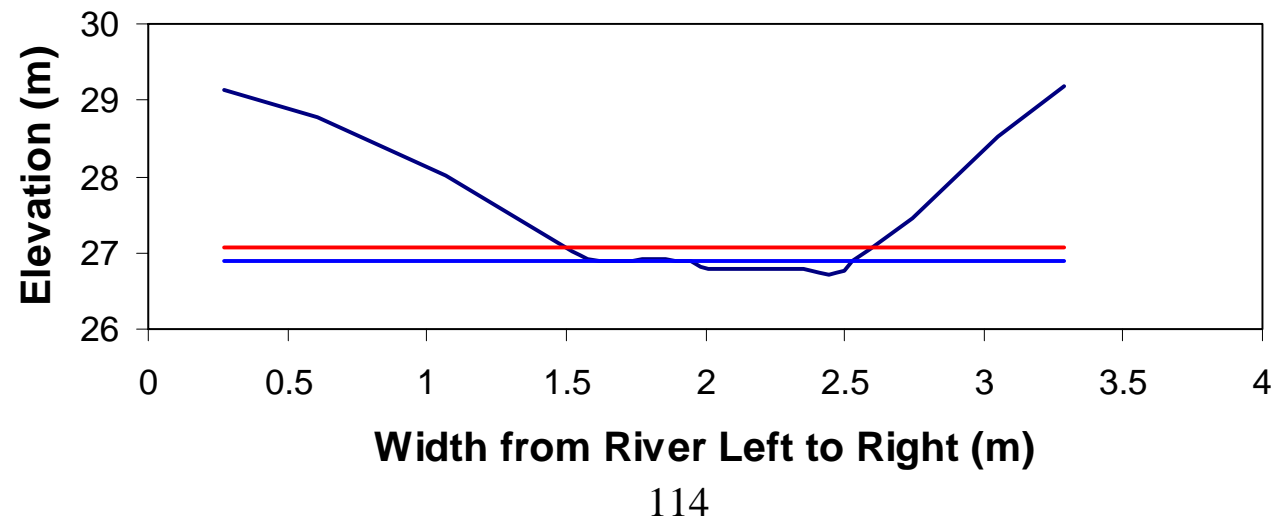




\section{Sediment Characteristics}

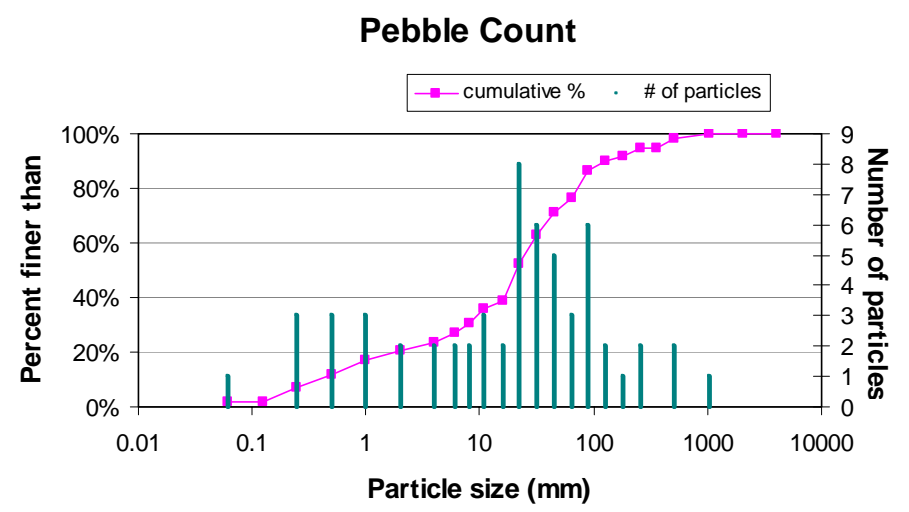

Size Percent Less than (mm): Based on sediment particles only

\begin{tabular}{cccccc}
\hline D16 & D35 & D50 & D65 & D84 & D95 \\
\hline 0.9 & 10.6 & 20.7 & 35 & 83 & 365 \\
\hline & Percent by & Substrate Type: Based on total count & \\
\hline Silt/Clay & Sand & Gravel & Cobble & Boulder & Bedrock \\
\hline $1 \%$ & $11 \%$ & $33 \%$ & $11 \%$ & $3 \%$ & $41 \%$ \\
\hline
\end{tabular}

\section{Right Bank}

Texture: Silty Clay Loam

Aggregate Stability: $21.2 \%$

LOI Organic Matter: 2.72\%

H202 Organic Matter: 1.75\%

Rock Fragments: 50\%

K Factor: 0.2

LS Factor: 4.9

C:N Ratio: 1:0.04

$\mathrm{pH}: 2.94$

\section{$\underline{\text { Soil Characteristics }}$}

\section{Left Bank}

Texture: Silty Clay

Aggregate Stability: $21.4 \%$

LOI Organic Matter: 2.75\%

H202 Organic Matter: 1.25\%

Rock Fragments: 50\%

K Factor: 0.23

LS Factor: 6.3

C:N Ratio; 1:0.05

$\mathrm{pH}: 2.93$

\begin{tabular}{|c|c|c|c|c|c|c|c|c|c|c|}
\hline \multicolumn{11}{|c|}{ Particle Size (3A1) } \\
\hline \multicolumn{6}{|c|}{ Total (mm) } & \multicolumn{5}{|c|}{ Sand (mm) } \\
\hline $\begin{array}{l}\text { Steam } \\
\text { Bank }\end{array}$ & $\begin{array}{c}\text { Clay } \\
(<.002)\end{array}$ & $\begin{array}{l}\text { Fine silt } \\
(.02-.002)\end{array}$ & $\begin{array}{c}\text { Coarse } \\
\text { Silt } \\
(.05-.02) \\
\end{array}$ & $\begin{array}{l}\text { Total Silt } \\
(.05-.002)\end{array}$ & $\begin{array}{l}\text { Sand } \\
(2-.05)\end{array}$ & $\begin{array}{l}\text { Very } \\
\text { Coarse } \\
(2.0-1.0)\end{array}$ & $\begin{array}{c}\text { Coarse } \\
(1.0-5)\end{array}$ & $\begin{array}{c}\text { Medium } \\
(.5-.25) \\
\end{array}$ & \begin{tabular}{|c|} 
Fine \\
$(.25-.1)$
\end{tabular} & $\begin{array}{c}\text { Very } \\
\text { Fine } \\
(.1-.05) \\
\end{array}$ \\
\hline Right & 37.93 & 34.77 & 14.98 & 49.75 & 12.32 & 0.09 & 0.06 & 0.06 & 0.39 & 0.52 \\
\hline Left & 42.42 & 39.46 & 10.83 & 50.29 & 7.28 & 0.085 & 0.11 & 0.07 & 0.11 & 0.245 \\
\hline
\end{tabular}




\section{SLATY FORK: REACH FOUR}

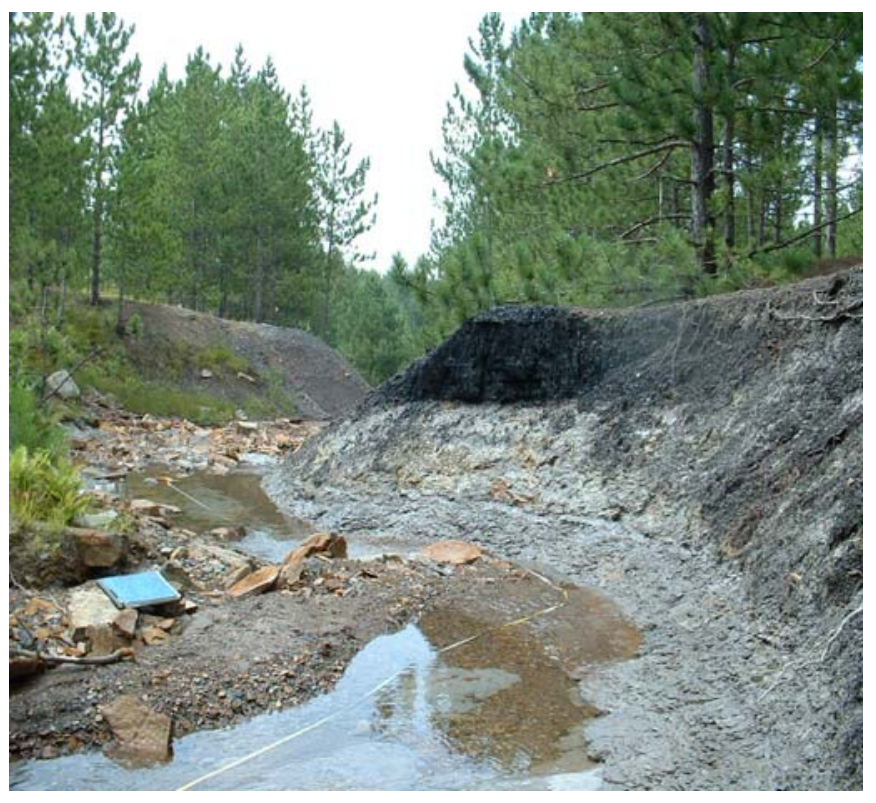

Downstream View

\section{Profile Characteristics}

Bankfull stage width: $6.9 \mathrm{~m}$

Mean bankfull stage depth: $0.1 \mathrm{~m}$

Mean bank height: $3 \mathrm{~m}$

Bank slope angle: $38^{\circ}$

Pool to riffle ratio: 1:5

Channel gradient: $4.45 \%$

\section{Morphological Relationships}

Width to depth ratio: 70.6

Entrenchment: 1.3

Sinuosity: 1.22

Bank height/bankfull stage height: 25.0 Rooting depth/bank height: 0.11

BEHI rating: 37 (High)

\section{Hydraulic Characteristics}

Bankfull discharge (3yr): 162.19 l/s

Bankfull discharge (1.5yr): $102.51 \mathrm{l} / \mathrm{s}$

Stream power (3yr): $1.17 \mathrm{~kg}^{3} / \mathrm{m} / \mathrm{s}$

Stream power (1.5yr): $0.74 \mathrm{~kg}^{3} / \mathrm{m} / \mathrm{s}$

Vegetation Characteristics: Vegetation covered about $13 \%$ of the channel banks. Sparse grasses and red pine were the dominant species present.

Channel Description: Moderately entrenched channel with a steep slope. Dominant channel materials were gravel and bedrock, while sand and cobble occurred less frequently within the channel. Streambanks consisted of silty clay textures.

Representative Cross Section

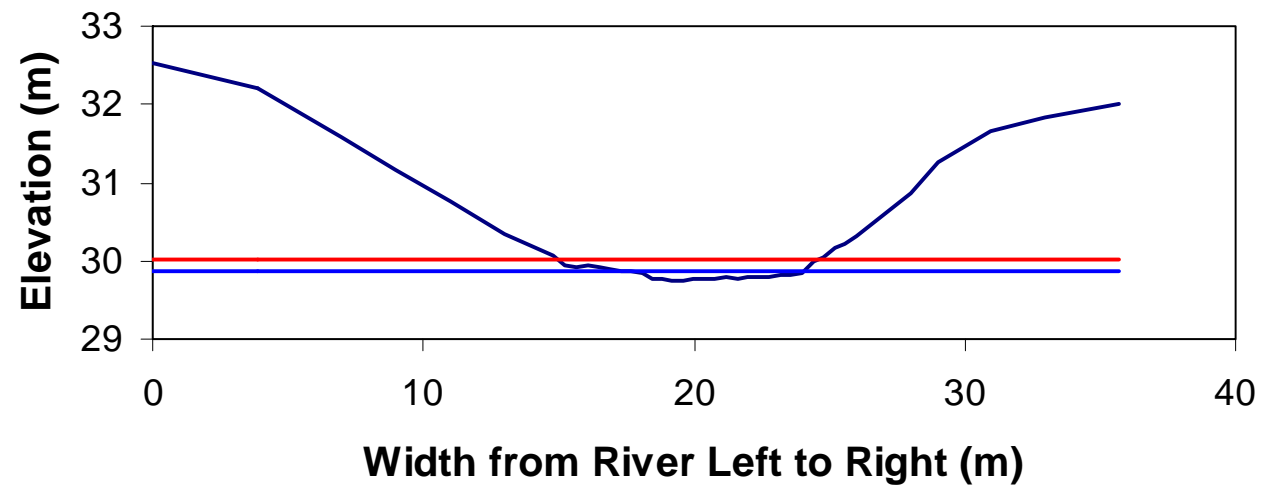




\section{Sediment Characteristics}

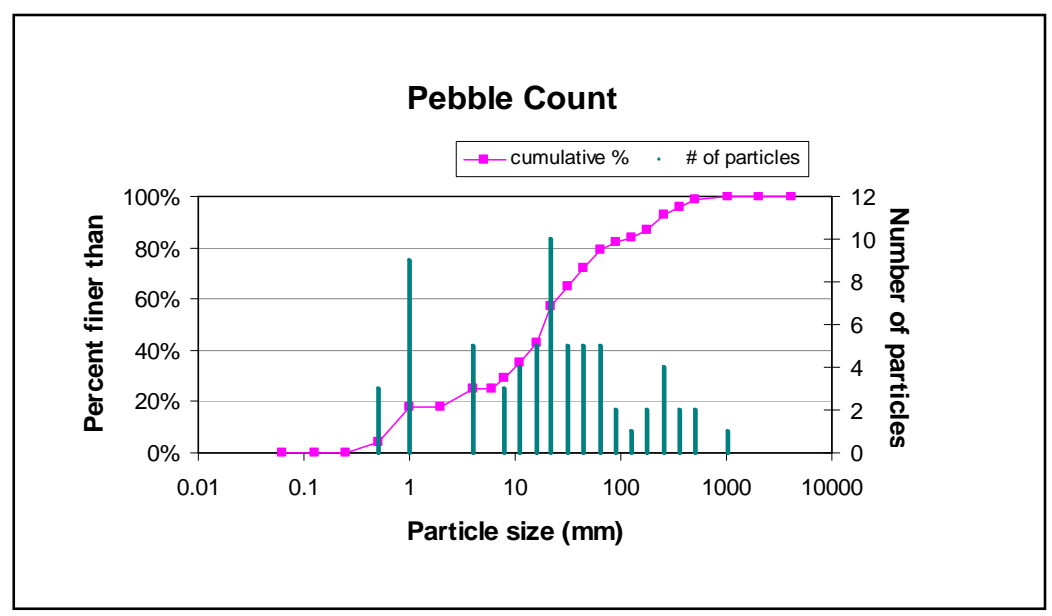

Size Percent Less than (mm): Based on sediment particles only

\begin{tabular}{cccccc}
\hline D16 & D35 & D50 & D65 & D84 & D95 \\
\hline 0.9 & 10.8 & 18.8 & 32 & 131 & 338 \\
\hline
\end{tabular}

Percent by Substrate Type: Based on total count

\begin{tabular}{cccccc}
\hline Silt/Clay & Sand & Gravel & Cobble & Boulder & Bedrock \\
\hline $0 \%$ & $12 \%$ & $42 \%$ & $9 \%$ & $5 \%$ & $32 \%$ \\
\hline
\end{tabular}

Right Bank

\section{$\underline{\text { Soil Characteristics }}$}

Texture: Silty Clay Loam

Aggregate Stability: $27.2 \%$

LOI Organic Matter: 3.02\%

H202 Organic Matter: 1.6

Rock Fragments: 50\%

K Factor: 0.21

LS Factor: 2.4

C:N Ratio: 1:0.04

pH: 3.45

\section{Left Bank}

Texture: Silty Clay Loam

Aggregate Stability: $25.6 \%$

LOI Organic Matter: 4.89\%

H202 Organic Matter: 2.25\%

Rock Fragments: 20\%

K Factor: 0.2

LS Factor: 4.8

C:N Ratio: 1:0.02

pH: 3.23

\begin{tabular}{|c|c|c|c|c|c|c|c|c|c|c|}
\hline \multicolumn{11}{|c|}{ Particle Size (3A1) } \\
\hline \multicolumn{6}{|c|}{ Total (mm) } & \multicolumn{5}{|c|}{ Sand (mm) } \\
\hline $\begin{array}{l}\text { Steam } \\
\text { Bank }\end{array}$ & $\begin{array}{c}\text { Clay } \\
(<.002)\end{array}$ & $\begin{array}{l}\text { Fine silt } \\
(.02-.002)\end{array}$ & $\begin{array}{c}\text { Coarse } \\
\text { Silt } \\
(.05-.02)\end{array}$ & $\begin{array}{l}\text { Total Silt } \\
(.05-.002)\end{array}$ & $\begin{array}{l}\text { Sand } \\
(2-.05)\end{array}$ & $\begin{array}{c}\text { Very } \\
\text { Coarse } \\
(2.0-1.0)\end{array}$ & $\begin{array}{c}\text { Coarse } \\
(1.0-.5)\end{array}$ & $\begin{array}{c}\text { Medium } \\
(.5-.25)\end{array}$ & $\begin{array}{c}\text { Fine } \\
(.25-.1)\end{array}$ & $\begin{array}{c}\text { Very } \\
\text { Fine } \\
(.1-.05)\end{array}$ \\
\hline Right & 38.45 & 30.44 & 25.21 & 55.65 & 5.90 & 0.06 & 0.1 & 0.09 & 0.12 & 0.13 \\
\hline Left & 38.98 & 29.62 & 22.31 & 51.93 & 9.09 & 0.13 & 0.16 & 0.15 & 0.18 & 0.18 \\
\hline
\end{tabular}




\section{SLATY FORK: REACH FIVE}

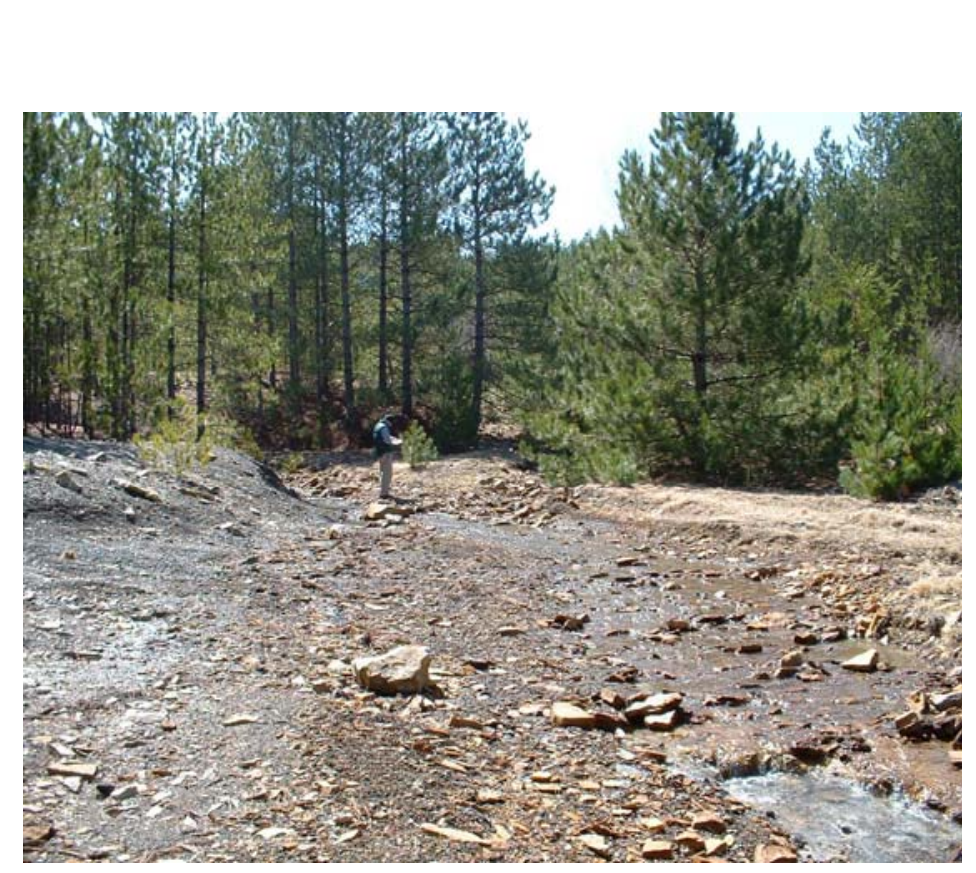

Upstream View

\section{Profile Characteristics}

Bankfull stage width: $4.8 \mathrm{~m}$

Mean bankfull stage depth: $0.2 \mathrm{~m}$

Mean bank height: $0.6 \mathrm{~m}$

Bank slope angle: $38^{\circ}$

Pool to riffle ratio: $1: 1.8$

Channel gradient: $3.8 \%$

\section{Morphological Relationships}

Width to depth ratio: 25.4

Entrenchment: 4.8

Sinuosity: 1.51

Bank height/bankfull stage height: 1.11

Rooting depth/bank height: 0.55

BEHI rating: 27.8 (Moderate)

\section{Hydraulics Characteristics}

Bankfull discharge (3yr): 176.36 l/s

Bankfull discharge (1.5yr): $111.40 \mathrm{l} / \mathrm{s}$

Stream power (3yr): $1.22 \mathrm{~kg}^{3} / \mathrm{m} / \mathrm{s}$

Stream power (1.5yr): $0.77 \mathrm{~kg}^{3} / \mathrm{m} / \mathrm{s}$

Vegetation Characteristics: Vegetation covered about $13 \%$ of the surrounding area. The right bank generally had no vegetation. Red pine and grasses were the prominent species on the left bank.

Channel Description: Slightly entrenched channel with a moderate slope. Dominant channel materials were grave with cobble and sand occur much less frequently. Channel banks consisted of clay loam textures. The streambed resembled a braided channel at the low flow stage in which it was observed.

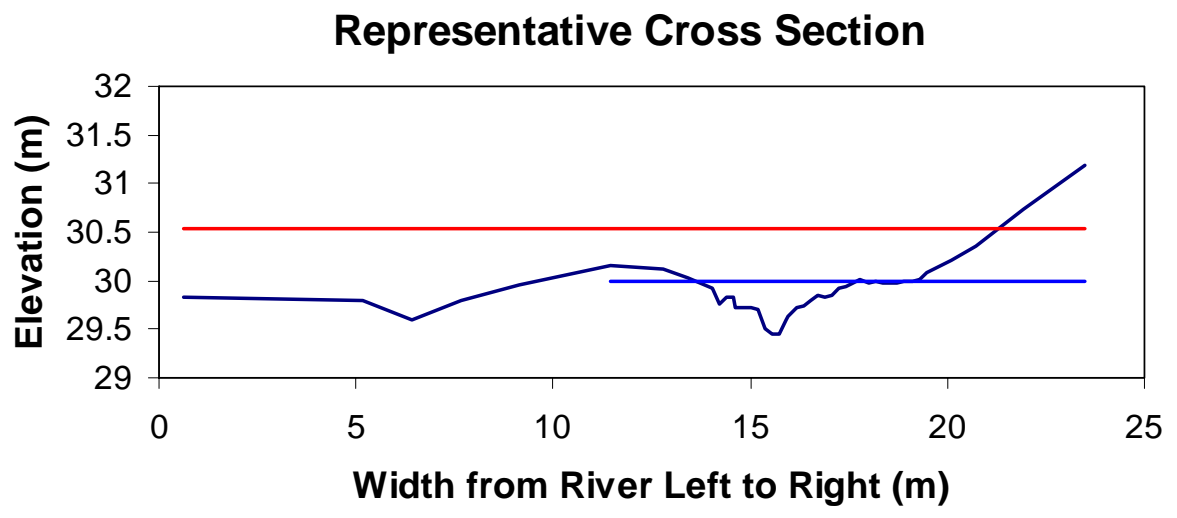




\section{Sediment Characteristics}

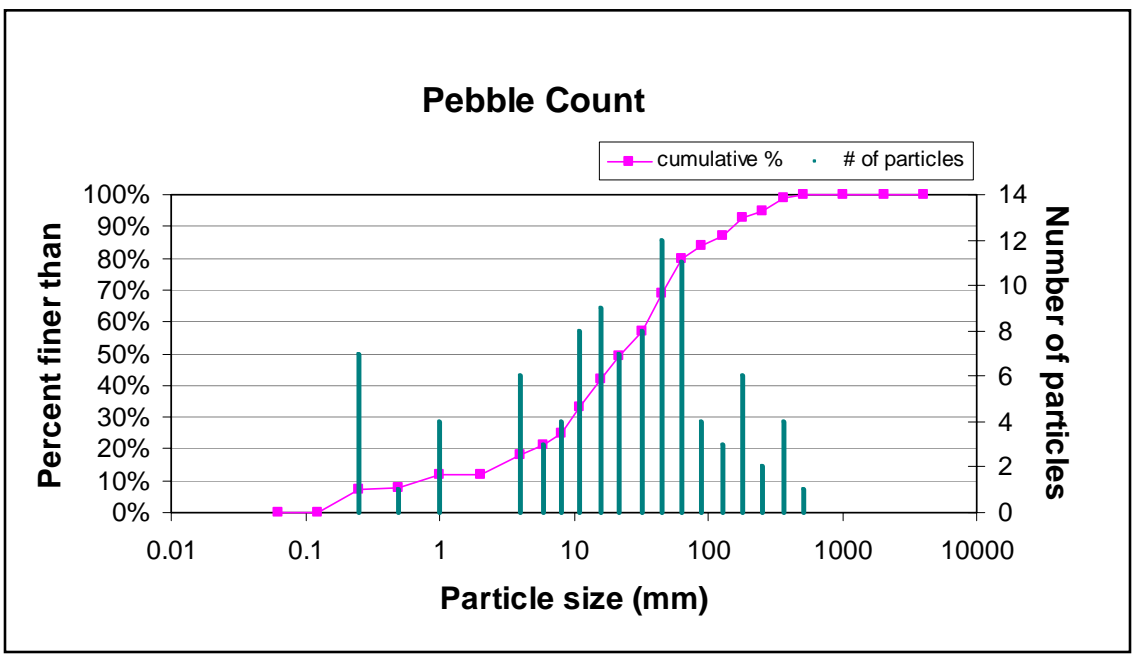

Size Percent Less than (mm): Based on sediment particles only

\begin{tabular}{cccccc}
\hline D16 & D35 & D50 & D65 & D84 & D95 \\
\hline 3.2 & 12 & 23.1 & 40 & 90 & 256 \\
\hline
\end{tabular}

Percent by Substrate Type: Based on total count

\begin{tabular}{cccccc}
\hline Silt/Clay & Sand & Gravel & Cobble & Boulder & Bedrock \\
\hline $0 \%$ & $12 \%$ & $68 \%$ & $15 \%$ & $5 \%$ & $0 \%$ \\
\hline
\end{tabular}

Right Bank

\section{$\underline{\text { Soil Characteristics }}$}

Texture: Loam

Aggregate Stability: 7\%

LOI Organic Matter: 5.89\%

H202 Organic Matter: $\quad 2.2 \%$

Rock Fragments: 50\%

K Factor: 0.26

LS Factor: 1.6

C:N Ratio: 1:0.03

$\mathrm{pH}: 3.3$

\section{Left Bank}

Texture: Clay Loam

Aggregate Stability: 14.6\%

LOI Organic Matter: $5.17 \%$

H202 Organic Matter: $2.5 \%$

Rock Fragments: 30\%

K Factor: 0.24

LS Factor: 1.5

C:N Ratio: 1:0.03

pH: 3.06

\begin{tabular}{|c|c|c|c|c|c|c|c|c|c|c|}
\hline \multicolumn{11}{|c|}{ Particle Size (3A1) } \\
\hline \multicolumn{6}{|c|}{ Total (mm) } & \multicolumn{5}{|c|}{ Sand (mm) } \\
\hline $\begin{array}{l}\text { Steam } \\
\text { Bank }\end{array}$ & $\begin{array}{c}\text { Clay } \\
(<.002)\end{array}$ & $\begin{array}{l}\text { Fine silt } \\
(.02-.002)\end{array}$ & $\begin{array}{c}\text { Coarse } \\
\text { Silt } \\
(.05-.02) \\
\end{array}$ & $\begin{array}{l}\text { Total Silt } \\
(.05-.002)\end{array}$ & $\begin{array}{l}\text { Sand } \\
(2-.05)\end{array}$ & $\begin{array}{l}\text { Very } \\
\text { Coarse } \\
(2.0-1.0) \\
\end{array}$ & $\begin{array}{c}\text { Coarse } \\
(1.0-.5) \\
\end{array}$ & $\begin{array}{c}\text { Medium } \\
(.5-.25)\end{array}$ & $\begin{array}{c}\text { Fine } \\
(.25-.1)\end{array}$ & $\begin{array}{c}\text { Very } \\
\text { Fine } \\
(.1-.05) \\
\end{array}$ \\
\hline Right & 25.52 & 30.13 & 8.51 & 38.64 & 35.84 & 0.99 & 0.93 & 0.72 & 0.5 & 0.32 \\
\hline Left & 28.85 & 33.27 & 9.14 & 42.40 & 28.75 & 0.81 & 0.85 & 0.61 & 0.34 & 0.21 \\
\hline
\end{tabular}




\section{SLATY FORK: REACH SIX}

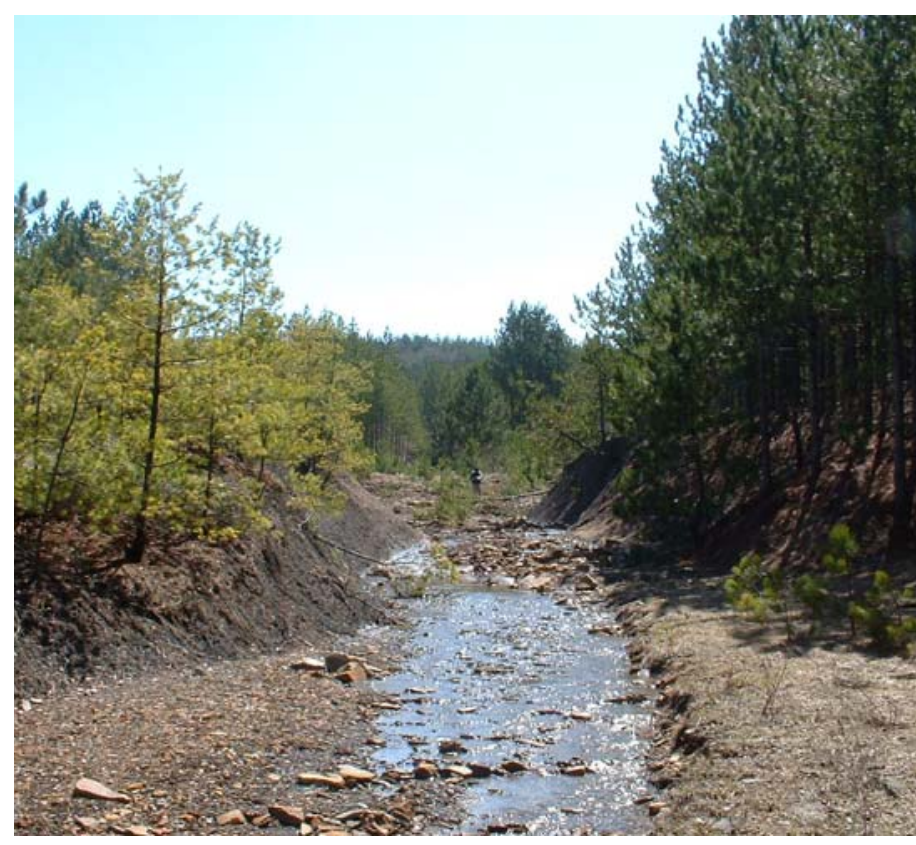

Upstream View

\section{Profile Characteristics}

Bankfull stage width: $3.2 \mathrm{~m}$

Mean bankfull stage depth: $0.1 \mathrm{~m}$

Mean bank height: $4 \mathrm{~m}$

Bank slope angle: $53^{\circ}$

Pool to riffle ratio: $1: 7$

Channel gradient: $2.9 \%$

Morphological Relationships

Width to depth ratio: 31.3

Entrenchment: 2.4

Sinuosity: 1.49

Bank height/bankfull stage height: 24.5

Rooting depth/bank height: 0.05

BEHI rating: 36.5 (High)

\section{Hydraulic Characteristics}

Bankfull discharge (3yr): $192.33 \mathrm{l} / \mathrm{s}$ Bankfull discharge (1.5yr): $121.43 \mathrm{l} / \mathrm{s}$ Stream power (3yr): $0.79 \mathrm{~kg}^{3} / \mathrm{m} / \mathrm{s}$ Stream power (1.5yr): $0.50 \mathrm{~kg}^{3} / \mathrm{m} / \mathrm{s}$

Vegetation Characteristics: Vegetation covered about 20\% of the channel banks. Red pine occurred at a moderate density on top of the right banks. Grass, mosses, and red pine occurred at a moderate density on the left bank.

Channel Description: Slightly entrenched channel with a gently gradient. The dominant channel materials were gravel, while cobble and sand occurred much less frequently. Streambanks consisted of silty clay and silt loam textures.

\section{Representative Cross Section}

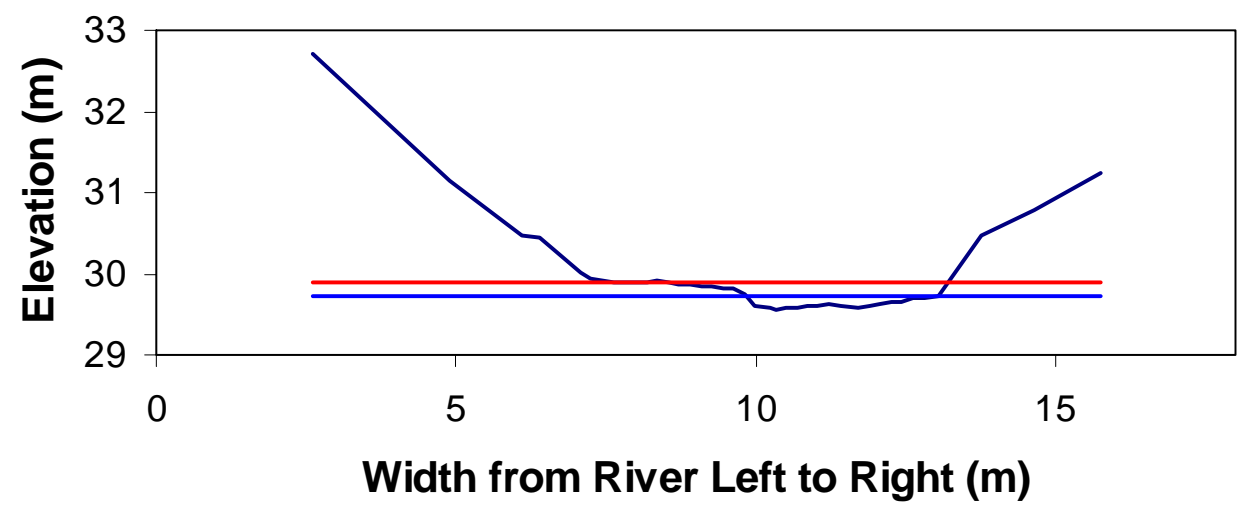




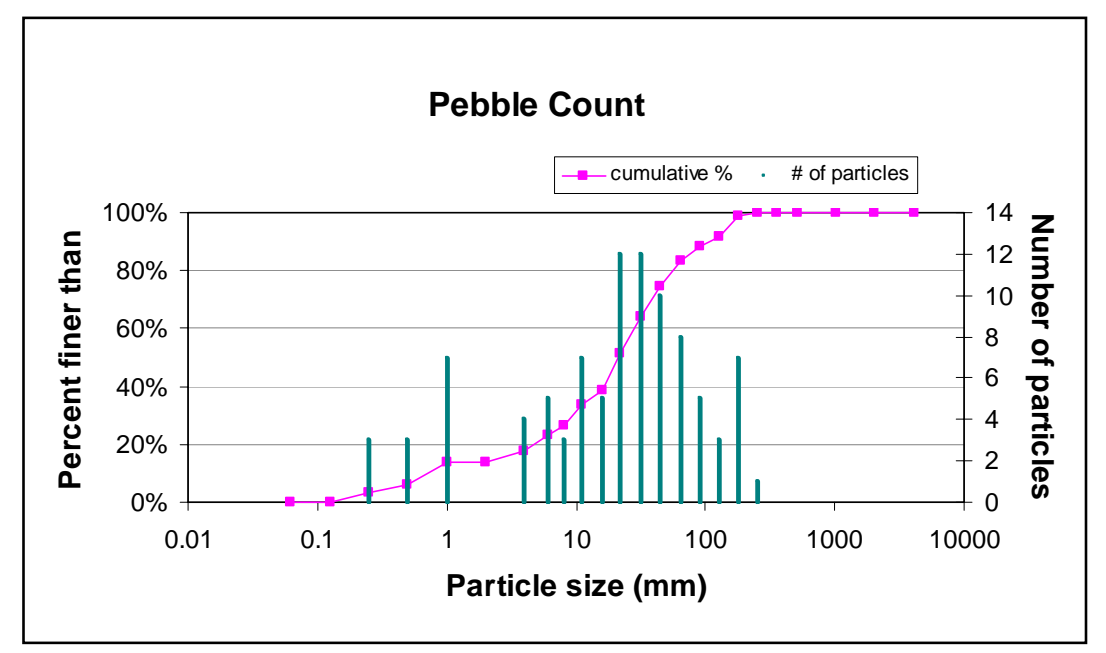

Size Percent Less than (mm): Based on sediment particles only

\begin{tabular}{clllll}
\hline D16 & D35 & D50 & D65 & D84 & D95 \\
\hline 3 & 12 & 21.1 & 33 & 68 & 150 \\
\hline & Percent by Substrate Type: Based on total count & \\
\hline Silt/Clay & Sand & Gravel & Cobble & Boulder & Bedrock \\
\hline $0 \%$ & $13 \%$ & $66 \%$ & $16 \%$ & $0 \%$ & $5 \%$ \\
\hline
\end{tabular}

\section{Soil Characteristics}

Right Bank

Texture: Silty Clay Loam

Aggregate Stability: $\quad 62.7 \%$

LOI Organic Matter: 8.47\%

H202 Organic Matter: $2.2 \%$

Rock Fragments: 60\%

K Factor: 0.23

LS Factor: 7.3

C:N Ratio: 1:0.02

pH: 4.44

\section{Left Bank}

Texture: Silt Loam

Aggregate Stability: 6.6

LOI Organic Matter: 8.41\%

H202 Organic Matter: $4.85 \%$

Rock Fragments: 7\%

K Factor: 0.23

LS Factor: 5.9

C:N Ratio: 1:0.03

pH: 3.32

\begin{tabular}{|c|c|c|c|c|c|c|c|c|c|c|}
\hline \multicolumn{11}{|c|}{ Particle Size (3A1) } \\
\hline \multicolumn{6}{|c|}{ Total (mm) } & \multicolumn{5}{|c|}{ Sand (mm) } \\
\hline $\begin{array}{l}\text { Steam } \\
\text { Bank }\end{array}$ & $\begin{array}{c}\text { Clay } \\
(<.002)\end{array}$ & $\begin{array}{l}\text { Fine silt } \\
(.02-.002)\end{array}$ & $\begin{array}{c}\text { Coarse } \\
\text { Silt } \\
(.05-.02) \\
\end{array}$ & $\begin{array}{l}\text { Total Silt } \\
(.05-.002)\end{array}$ & $\begin{array}{l}\text { Sand } \\
(2-.05)\end{array}$ & $\begin{array}{c}\text { Very } \\
\text { Coarse } \\
(2.0-1.0)\end{array}$ & $\begin{array}{c}\text { Coarse } \\
(1.0-.5) \\
\end{array}$ & $\begin{array}{c}\text { Medium } \\
(.5-.25) \\
\end{array}$ & \begin{tabular}{|l} 
Fine \\
$(.25-.1)$
\end{tabular} & $\begin{array}{c}\text { Very } \\
\text { Fine } \\
(.1-.05) \\
\end{array}$ \\
\hline Right & 32.57 & 36.43 & 14.88 & 51.32 & 16.11 & 0.16 & 0.24 & 0.25 & 0.29 & 0.61 \\
\hline Left & 24.93 & 37.22 & 15.81 & 53.03 & 22.04 & 0.04 & 0.36 & 0.34 & 0.46 & 0.48 \\
\hline
\end{tabular}




\section{SLATY FORK: REACH SEVEN}

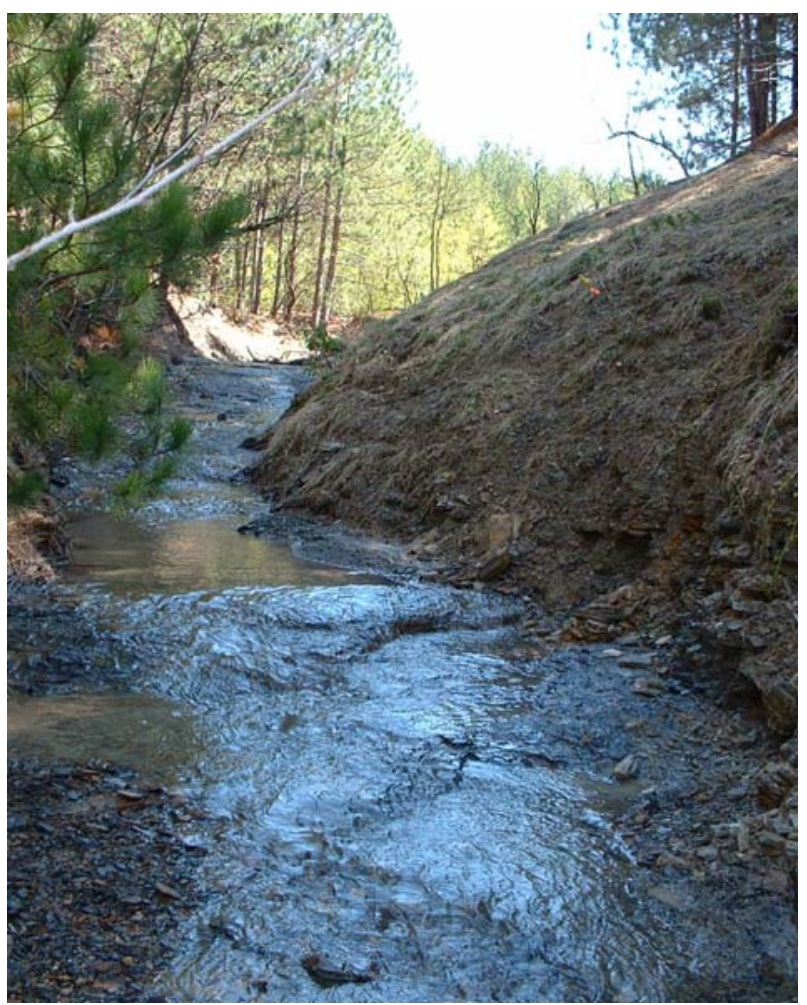

Upstream View

\section{Profile Characteristics}

Bankfull stage width: $2.8 \mathrm{~m}$

Mean bankfull stage depth: $0.2 \mathrm{~m}$

Mean bank height: $3 \mathrm{~m}$

Bank slope angle: $45^{\circ}$

Pool to riffle ratio: $1: 15$

Channel gradient: $4.00 \%$

\section{Morphological Relationships}

Width to Depth Ratio: 14.3

Entrenchment: 1.3

Sinuosity: 1.06

Bank height/bankfull stage height: 11.1

Rooting depth/bank height: 0.02

BEHI rating: 30.1 (High)

\section{Hydraulic Characteristics}

Bankfull discharge (3yr): 199.14 l/s

Bankfull discharge (1.5yr): $125.71 \mathrm{l} / \mathrm{s}$

Stream power (3yr): $1.16 \mathrm{~kg}^{3} / \mathrm{m} / \mathrm{s}$

Stream power (1.5yr): $0.73 \mathrm{~kg}^{3} / \mathrm{m} / \mathrm{s}$

Vegetation Characteristics: Vegetation covered about 55\% of the channel banks. The right bank was covered primarily with grasses, while red pine and autumn olive occur at a lesser density. Moderate to dense grasses covered the left bank.

Channel Description: Entrenched channel with a moderate slope. The dominate channel materials were bedrock and gravel. Streambanks consisted of silty clay loam and clay loam textures.

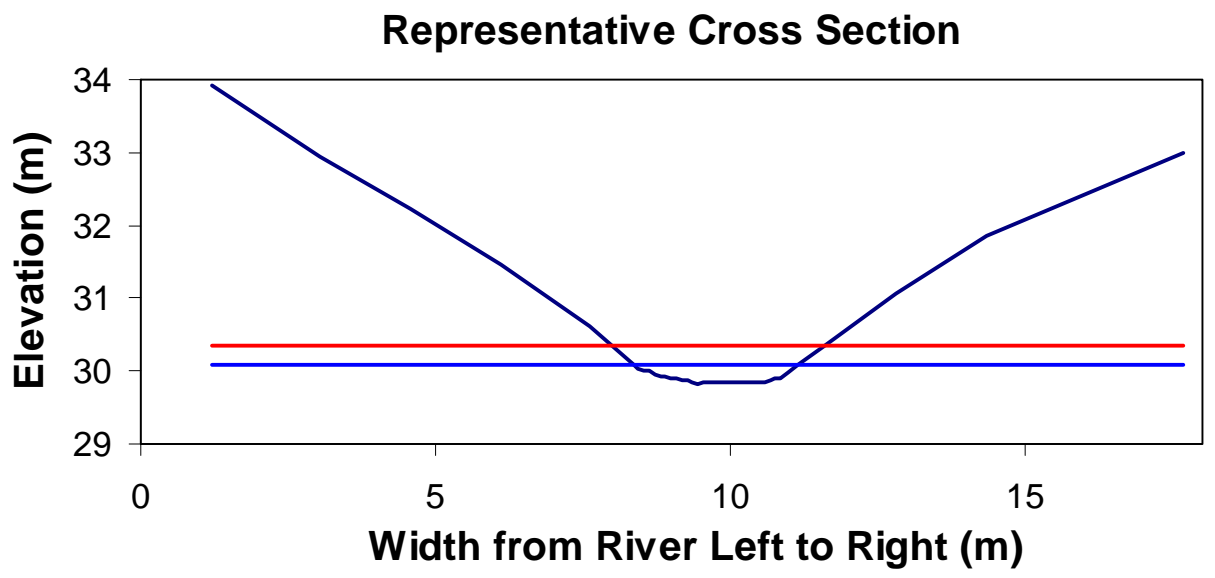




\section{Sediment Characteristics}

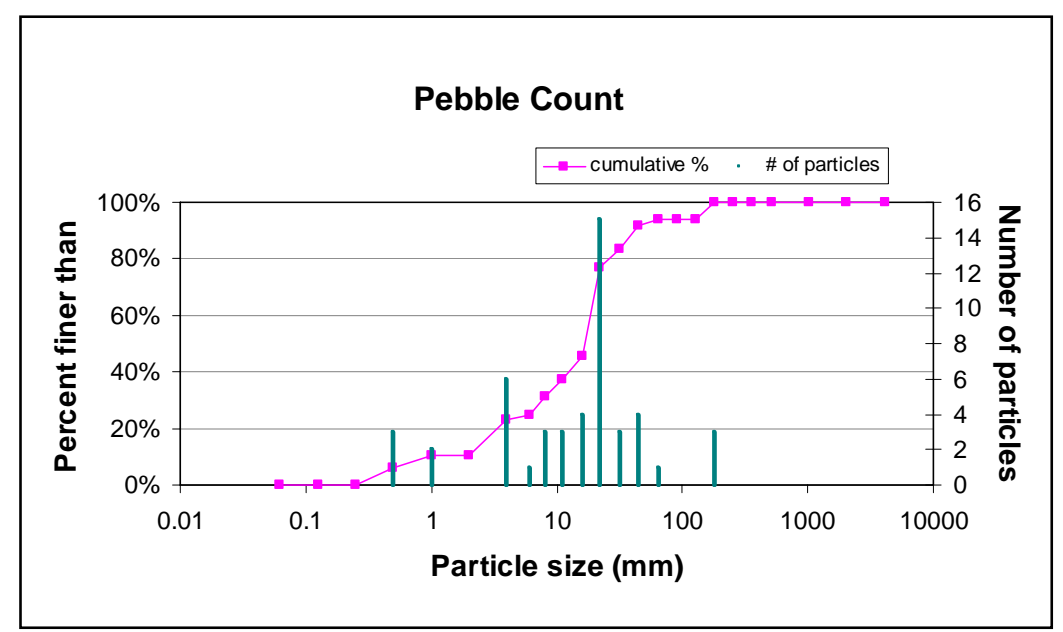

Size Percent Less than (mm): Based on sediment particles only

\begin{tabular}{cccccc} 
D16 & D35 & D50 & D65 & D84 & D95 \\
\hline 2.7 & 9.7 & 16.7 & 19 & 33 & 137 \\
\hline & & & & & \\
& Percent by Substrate Type: Based on total count & \\
\hline Silt/Clay & Sand & Gravel & Cobble & Boulder & Bedrock \\
\hline $0 \%$ & $5 \%$ & $40 \%$ & $3 \%$ & $0 \%$ & $52 \%$ \\
\hline
\end{tabular}

\section{Soil Characteristics}

Right Bank

Texture: Silty Clay Loam

Aggregate Stability: $\quad 8.4 \%$

LOI Organic Matter: 5.02\%

H202 Organic Matter: 3.25\%

Rock Fragments: 15\%

K Factor: 0.21

LS Factor: 4.8

C:N Ratio: 1:0.05

pH: 3.7

\section{Left Bank}

Texture: Loam

Aggregate Stability: $32.2 \%$

LOI Organic Matter: 7.31\%

H202 Organic Matter: 3.65\%

Rock Fragments: 20\%

K Factor: 0.22

LS Factor: 4.8

C:N Ratio: 1:0.04

$\mathrm{pH}: 4.34$

\begin{tabular}{|c|c|c|c|c|c|c|c|c|c|c|}
\hline \multicolumn{11}{|c|}{ Particle Size (3A1) } \\
\hline \multicolumn{6}{|c|}{ Total (mm) } & \multicolumn{5}{|c|}{ Sand (mm) } \\
\hline $\begin{array}{c}\text { Steam } \\
\text { Bank }\end{array}$ & $\begin{array}{c}\text { Clay } \\
(<.002)\end{array}$ & $\begin{array}{l}\text { Fine silt } \\
(.02-.002)\end{array}$ & $\begin{array}{c}\text { Coarse } \\
\text { Silt } \\
(.05-.02)\end{array}$ & $\begin{array}{l}\text { Total Silt } \\
(.05-.002)\end{array}$ & $\begin{array}{l}\text { Sand } \\
(2-.05)\end{array}$ & $\begin{array}{c}\text { Very } \\
\text { Coarse } \\
(2.0-1.0)\end{array}$ & $\begin{array}{c}\text { Coarse } \\
(1.0-.5)\end{array}$ & Medium & $\begin{array}{c}\text { Fine } \\
(.25-.1)\end{array}$ & $\begin{array}{c}\text { Very } \\
\text { Fine } \\
(.1-.05)\end{array}$ \\
\hline Right & 30.69 & 35.61 & 15.34 & 50.94 & 18.37 & 0.10 & 0.13 & 0.24 & 0.49 & 0.54 \\
\hline Left & 25.69 & 33.37 & 11.84 & 45.20 & 29.10 & 0.28 & 0.45 & 0.60 & 0.82 & 0.63 \\
\hline
\end{tabular}




\section{SLATY FORK: REACH EIGHT}

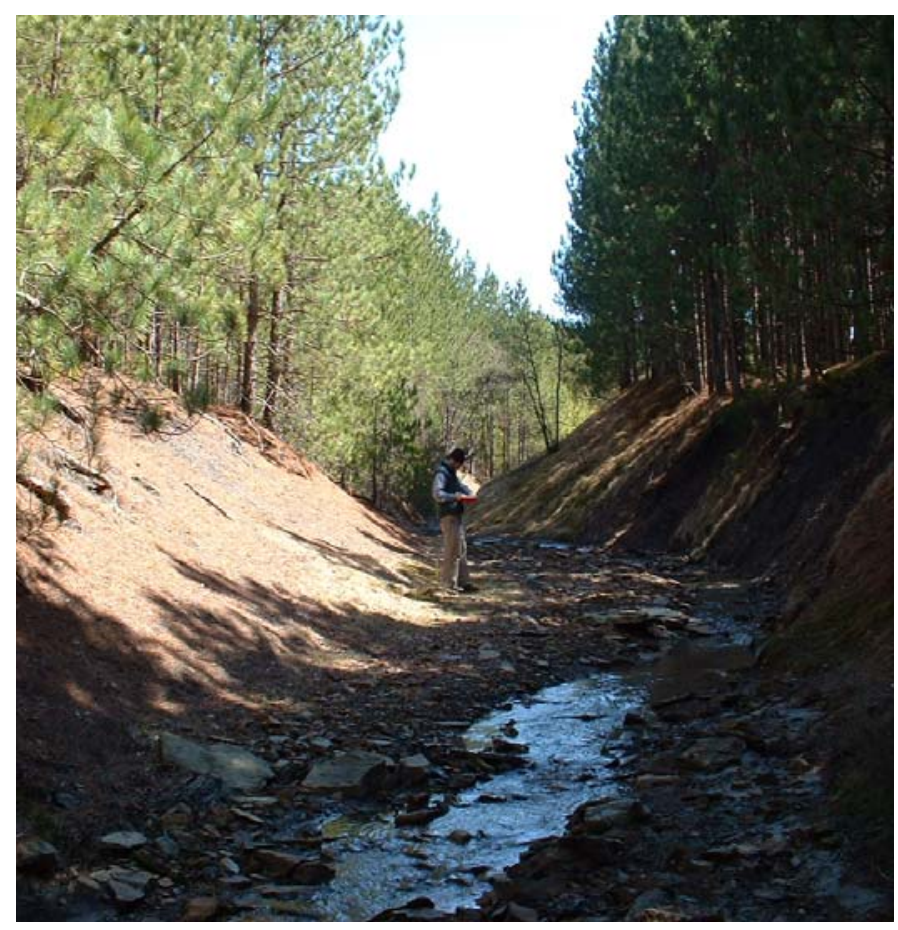

Upstream View

\section{Profile Characteristics}

Bankfull stage width: $2.5 \mathrm{~m}$

Mean bankfull stage depth: $0.1 \mathrm{~m}$

Mean bank height: $4.1 \mathrm{~m}$

Bank slope angle: $48^{\circ}$

Pool to riffle ratio: $1: 3.4$

Channel gradient: $2.60 \%$

Morphological Relationships

Width to depth ratio: 18.9

Entrenchment: 2.3

Sinuosity: 1.07

Bank height/bankfull stage height: 20

Rooting depth/bank height: 0.08

BEHI rating: 34 (High)

\section{Hydraulic Characteristics}

Bankfull discharge (3yr): 206.57 l/s

Bankfull discharge (1.5yr): $130.37 \mathrm{l} / \mathrm{s}$

Stream Power (3yr): $0.76 \mathrm{~kg}^{3} / \mathrm{m} / \mathrm{s}$ Stream Power (1.5yr): $0.48 \mathrm{~kg}^{3} / \mathrm{m} / \mathrm{s}$

Vegetation Characteristics: Vegetation covered about 30\% of the channel banks. The right bank had very sparse vegetation with red pine occurring on top of the right bank. The left bank had moderate vegetation, primarily grasses and red pine.

Channel Description: Slightly entrenched channel with a gentle slope. Dominant channel materials were gravel, while cobble and sand occurred less frequently. Streambanks consisted of clay loam and loam textures.

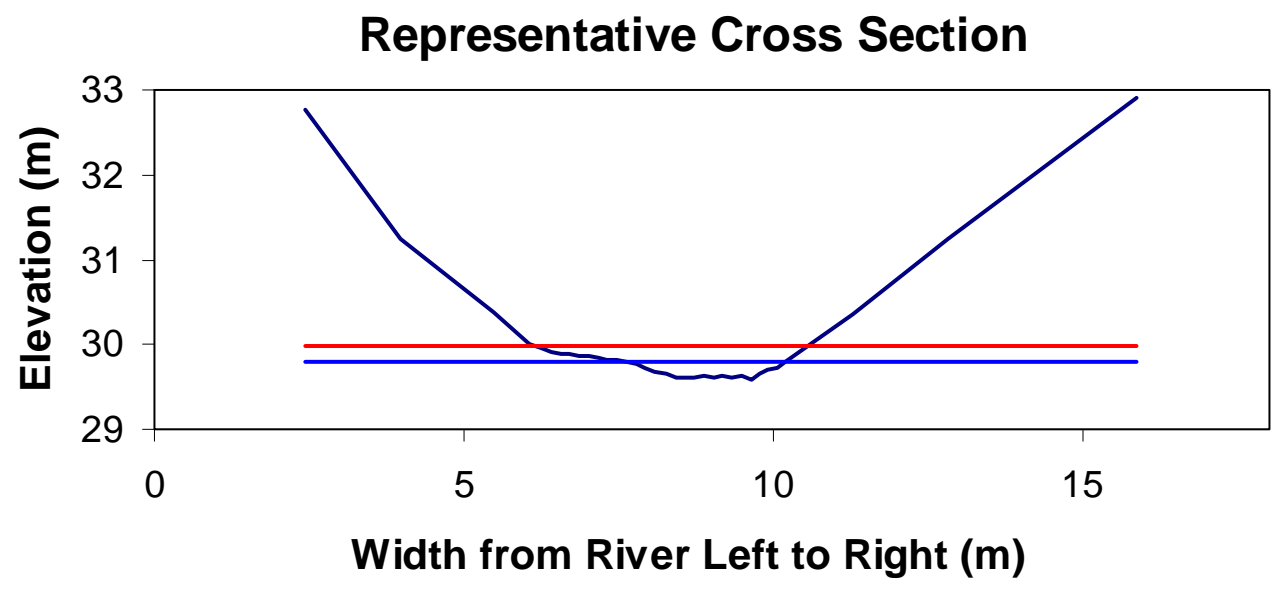




\section{Sediment Characteristics}

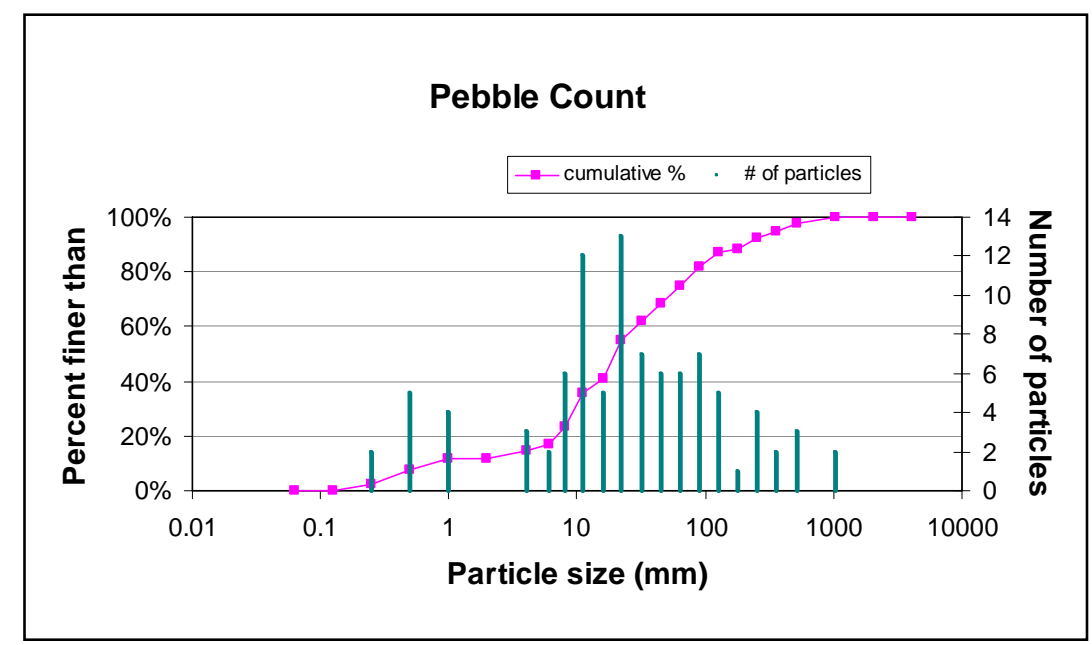

Size Percent Less than (mm): Based on sediment particles only

\begin{tabular}{llllll}
\hline D16 & D35 & D50 & D65 & D84 & D95 \\
\hline 5.1 & 10.8 & 19.7 & 37 & 102 & 373 \\
\hline
\end{tabular}

Percent by Substrate Type: Based on total count

\begin{tabular}{cccccc}
\hline Silt/Clay & Sand & Gravel & Cobble & Boulder & Bedrock \\
\hline $0 \%$ & $11 \%$ & $60 \%$ & $17 \%$ & $7 \%$ & $5 \%$ \\
\hline
\end{tabular}

\section{$\underline{\text { Soil Characteristics }}$}

\section{Right Bank}

Texture: Loam

Aggregate Stability: $76.8 \%$

LOI Organic Matter: $13.99 \%$

H202 Organic Matter: 7.20\%

Rock Fragments: 10\%

K Factor: 0.21

LS Factor: 4.4

C:N Ratio: 1:0.03

pH: 3.24
Left Bank

Texture: Loam

Aggregate Stability: $78.6 \%$

LOI Organic Matter: $11.88 \%$

H202 Organic Matter: $6.55 \%$

Rock Fragments: $20 \%$

K Factor: 0.24

LS Factor: 8.0

C:N Ratio: 1:0.02

$\mathrm{pH}: 3.76$

\begin{tabular}{|c|c|c|c|c|c|c|c|c|c|c|}
\hline \multicolumn{11}{|c|}{ Particle Size (3A1) } \\
\hline \multicolumn{6}{|c|}{ Total (mm) } & \multicolumn{5}{|c|}{ Sand (mm) } \\
\hline $\begin{array}{c}\text { Steam } \\
\text { Bank }\end{array}$ & $\begin{array}{c}\text { Clay } \\
(<.002)\end{array}$ & $\begin{array}{c}\text { Fine silt } \\
(.02-.002)\end{array}$ & $\begin{array}{c}\text { Coarse } \\
\text { Silt } \\
(.05-.02)\end{array}$ & $\begin{array}{l}\text { Total Silt } \\
(.05-.002)\end{array}$ & $\begin{array}{l}\text { Sand } \\
(2-.05)\end{array}$ & $\begin{array}{c}\text { Very } \\
\text { Coarse } \\
(2.0-1.0)\end{array}$ & $\begin{array}{c}\text { Coarse } \\
(1.0-.5)\end{array}$ & $\begin{array}{c}\text { Medium } \\
(.5-.25)\end{array}$ & $\begin{array}{c}\text { Fine } \\
(.25-.1)\end{array}$ & $\begin{array}{c}\text { Very } \\
\text { Fine } \\
(.1-.05)\end{array}$ \\
\hline Right & 22.07 & 42.09 & 8.76 & 48.14 & 27.08 & 0.68 & 0.40 & 0.25 & 0.43 & 0.46 \\
\hline Left & 19.54 & 22.56 & 22.34 & 44.90 & 35.56 & 0.19 & 0.24 & 0.50 & 1.17 & 1.14 \\
\hline
\end{tabular}




\section{SLATY FORK: REACH NINE}

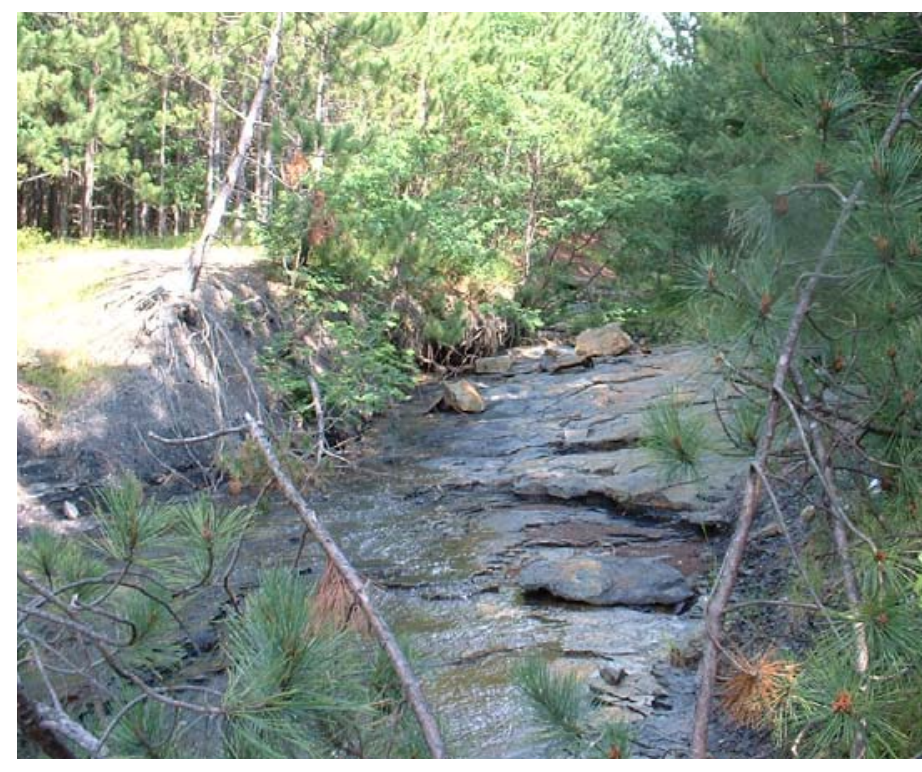

Upstream View

\section{Profile Characteristics}

Bankfull stage width: $3.2 \mathrm{~m}$

Mean bankfull stage depth: $0.1 \mathrm{~m}$

Mean bank height: $2.4 \mathrm{~m}$

Bank slope angle: $80^{\circ}$

Pool to riffle ratio: $1: 15$

Channel gradient: $6.81 \%$

\section{Morphological Relationships}

Width to depth ratio: 36

Entrenchment: 1.7

Sinuosity: 1.4

Bank height/bankfull stage height: 8

Rooting depth/bank height: 0.38

BEHI rating: 31.6 (High)

\section{Hydraulic Characteristics}

Bankfull discharge (3yr): $211.68 \mathrm{l} / \mathrm{s}$

Bankfull discharge (1.5yr): $133.57 \mathrm{l} / \mathrm{s}$

Stream Power (3yr): $6.45 \mathrm{~kg}^{3} / \mathrm{m}$

Stream Power (1.5yr): $4.07 \mathrm{~kg}^{3} / \mathrm{m}$

Vegetation Characteristics: Vegetation covers about 33\% of the channel banks. The right bank consists of very a very sparse density of red pine. Sparse grass and red pine cover the left bank.

Channel Description: Moderately entrenched channel with a steep gradient. The dominant channel materials are bedrock with cobble and gravel occurring at a much lesser frequency. Sediment supply is high with streambanks consisting of clay and clay loam textures.

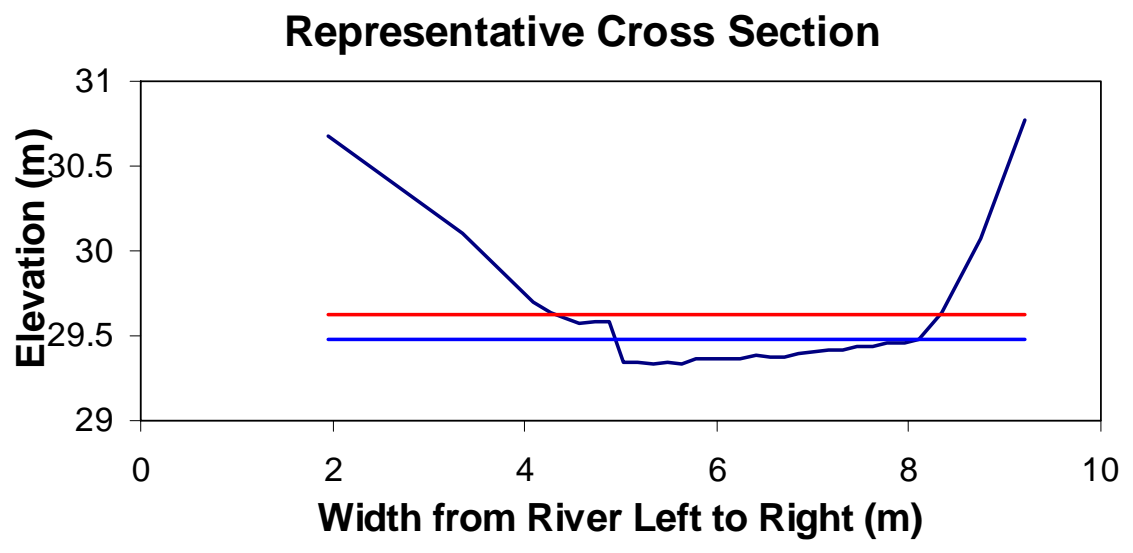




\section{Sediment Characteristics}

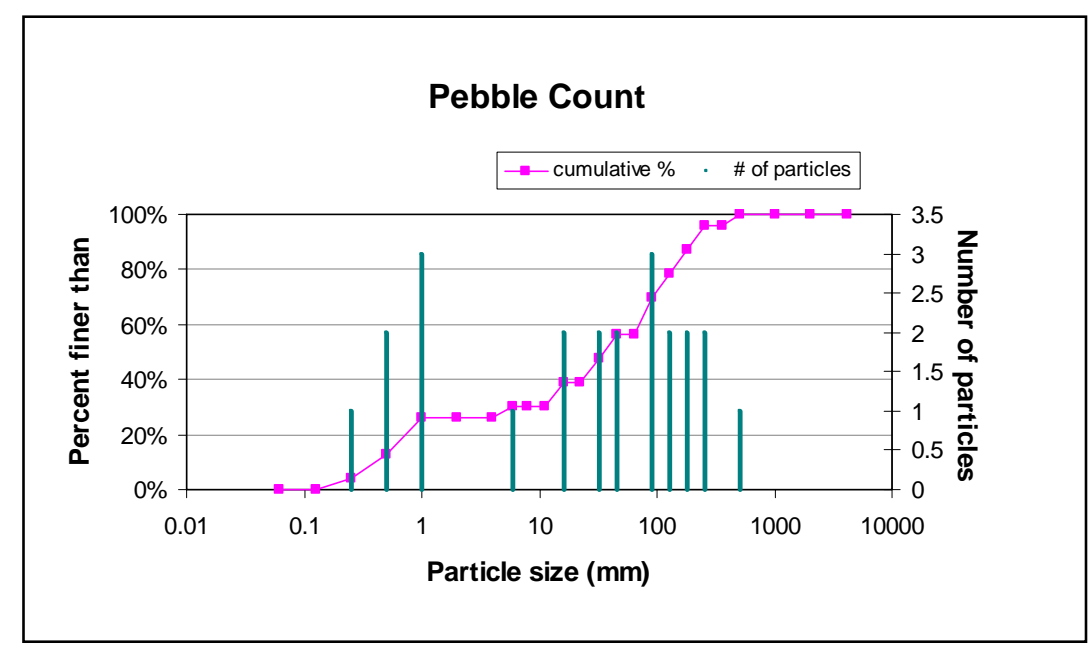

Size Percent Less than (mm): Based on sediment particles only

\begin{tabular}{cccccc}
\hline D16 & D35 & D50 & D65 & D84 & D95 \\
\hline 0.6 & 13.4 & 34.8 & 80 & 160 & 249 \\
\hline
\end{tabular}

Percent by Substrate Type: Based on total count

\begin{tabular}{cccccc}
\hline Silt/Clay & Sand & Gravel & Cobble & Boulder & Bedrock \\
\hline $0 \%$ & $6 \%$ & $7 \%$ & $9 \%$ & $1 \%$ & $77 \%$ \\
\hline
\end{tabular}

\section{$\underline{\text { Soil Characteristics }}$}

Right Bank

Texture: Clay

Aggregate Stability: $8.4 \%$

LOI Organic Matter: $10.31 \%$

H202 Organic Matter: 2\%

Rock Fragments: 95\%

K Factor: 0.16

LS Factor: 10.0

C:N Ratio: 1:0.03

pH: 3.83
Left Bank

Texture: Clay Loam

Aggregate Stability: $12.8 \%$

LOI Organic Matter: 31.89\%

H202 Organic Matter: 2.8\%

Rock Fragments: 75\%

K Factor: 0.23

LS Factor: 10.0

C:N Ratio: 1:0.02

pH: 4.13

\begin{tabular}{|c|c|c|c|c|c|c|c|c|c|c|}
\hline \multicolumn{11}{|c|}{ Particle Size (3A1) } \\
\hline \multicolumn{6}{|c|}{ Total (mm) } & \multicolumn{5}{|c|}{ Sand (mm) } \\
\hline $\begin{array}{c}\text { Steam } \\
\text { Bank }\end{array}$ & $\begin{array}{c}\text { Clay } \\
(<.002)\end{array}$ & $\begin{array}{l}\text { Fine silt } \\
(.02-.002)\end{array}$ & $\begin{array}{c}\text { Coarse } \\
\text { Silt } \\
(.05-.02) \\
\end{array}$ & $\begin{array}{l}\text { Total Silt } \\
(.05-.002)\end{array}$ & $\begin{array}{l}\text { Sand } \\
(2-.05)\end{array}$ & $\begin{array}{c}\text { Very } \\
\text { Coarse } \\
(2.0-1.0) \\
\end{array}$ & $\begin{array}{c}\text { Coarse } \\
(1.0-.5) \\
\end{array}$ & $\begin{array}{c}\text { Medium } \\
(.5-.25) \\
\end{array}$ & $\begin{array}{c}\text { Fine } \\
(.25-.1)\end{array}$ & $\begin{array}{c}\text { Very } \\
\text { Fine } \\
(.1-.05) \\
\end{array}$ \\
\hline Right & 53.09 & 20.62 & 15.21 & 35.83 & 11.08 & 0.24 & 0.30 & 0.20 & 0.19 & 0.12 \\
\hline Left & 32.60 & 22.15 & 12.90 & 35.05 & 32.35 & 0.61 & 0.74 & 0.67 & 0.59 & 0.39 \\
\hline
\end{tabular}




\section{SPHAGNUM RUN}

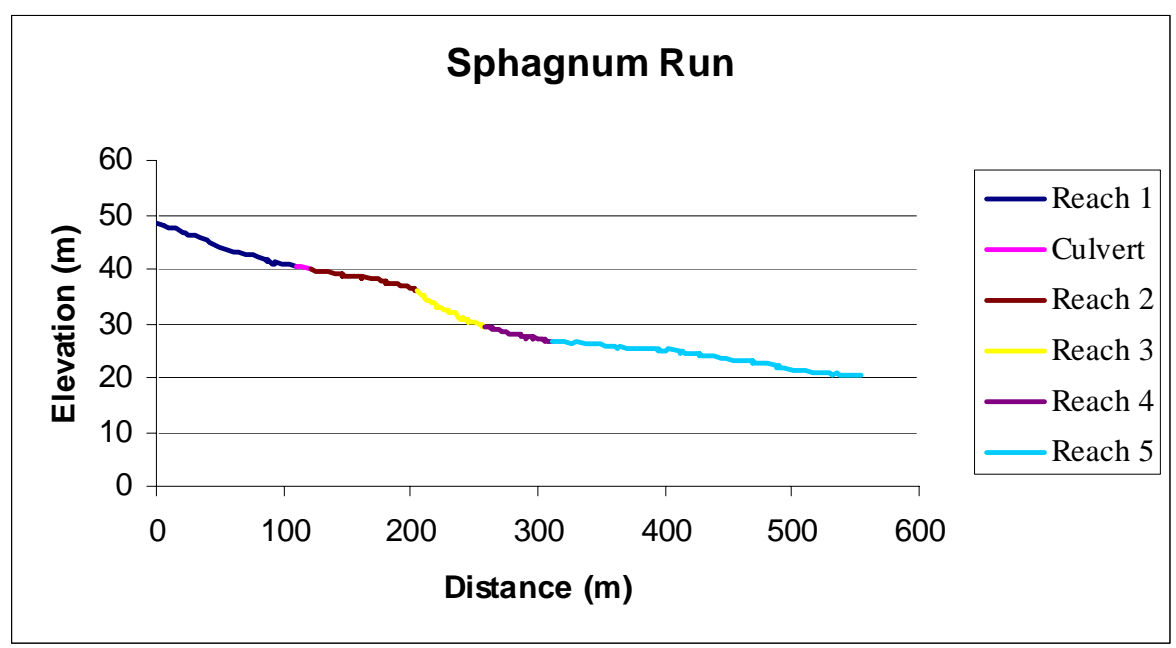

Longitudinal Profile

Site Location: Where surveying began

Latitude: 39॰09’37.4’’ N

Longitude: $79^{\circ} 24^{\prime} 52^{\prime \prime}$ ' W

Drainage area: $88261 \mathrm{~m}^{2}$

Stream Description: Sphagnum Run was the smallest of the three streams surveyed and had different characteristics. This stream was comprised of five reaches: two were classified as aggrading, two as wetland, and one as a step pool reach. Bedrock was not commonly exposed throughout this tributary. This stream had the steepest total slope, due to the steep (12\%) slope of the step pool reach (reach 3).

Relationships below were obtained by averaging values from stream reaches.

\section{Profile Characteristics}

Mean bankfull stage width: $2.46 \mathrm{~m}$

Mean bank height: $3.02 \mathrm{~m}$

Mean bank slope angle: $28^{\circ}$

Mean pool to riffle ratio: $1: 1.8$

Total channel gradient: $6.40 \%$

\section{Morphological Relationships}

Mean width to depth ratio: 35.06

Mean entrenchment ratio: 1.76

Total Sinuosity: 1.00

Total BEHI rating: 31.26 (High)

\section{Hydraulic Characteristics}

Mean bankfull discharge (3yr): 87.75 l/s

Mean bankfull discharge (1.5yr): $62.59 \mathrm{l} / \mathrm{s}$

Mean stream power (3yr): $1.71 \mathrm{~kg}^{3} / \mathrm{m} / \mathrm{s}$

Mean stream power (1.5yr): $1.09 \mathrm{~kg}^{3} / \mathrm{m} / \mathrm{s}$ 


\section{SPHAGNUM RUN: REACH ONE}

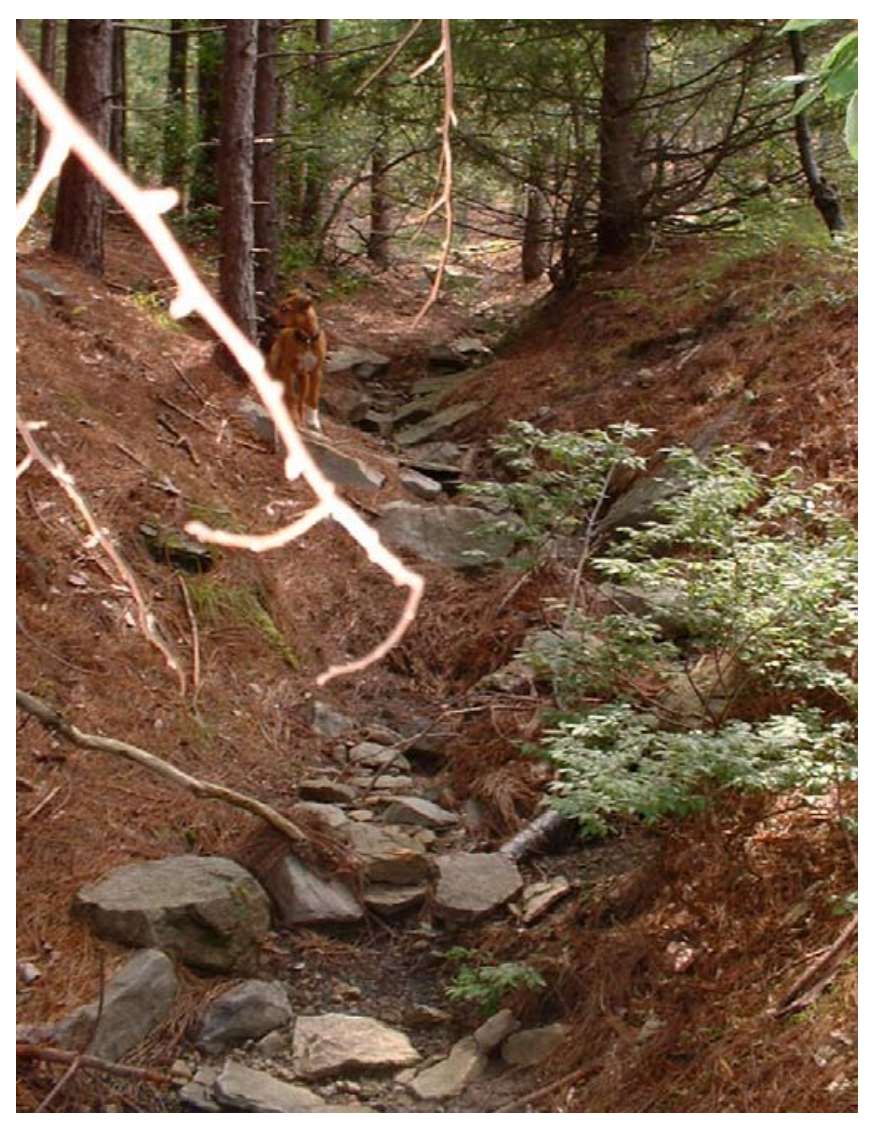

Upstream View

\section{Profile Characteristics}

Bankfull stage width: $1.1 \mathrm{~m}$

Mean bankfull stage depth: $0.1 \mathrm{~m}$

Mean bank height: $5.5 \mathrm{~m}$

Bank slope angle: $62^{\circ}$

Pool to riffle ratio: Not determined

Channel gradient: $6.91 \%$

\section{Morphological Relationships}

Width to depth ratio: 11.7

Entrenchment: 1.4

Sinuosity: 1.12

Bank height/bankfull stage height: 33.7

Rooting depth/bank height: .03

BEHI rating: 44 (Very High)

\section{Hydraulic Characteristics}

Bankfull discharge (3yr): 78.04 l/s

Bankfull discharge (1.5yr): $49.54 \mathrm{l} / \mathrm{s}$

Stream power (3yr): $0.33 \mathrm{~kg}^{3} / \mathrm{m} / \mathrm{s}$

Stream power (1.5yr): $0.21 \mathrm{~kg}^{3} / \mathrm{m} / \mathrm{s}$

Rosgen Stream Type: B4a (W/D ratio)

Vegetation Characteristics: Vegetation covered about 5\% of the channel banks. Red pines and fewer autumn olives occurred throughout the reach.

Channel Description: Moderately entrenched channel with a steep gradient. The dominant channel materials were gravel with cobble occurs much less frequently. Streambanks consisted of silt loam and loam textures.
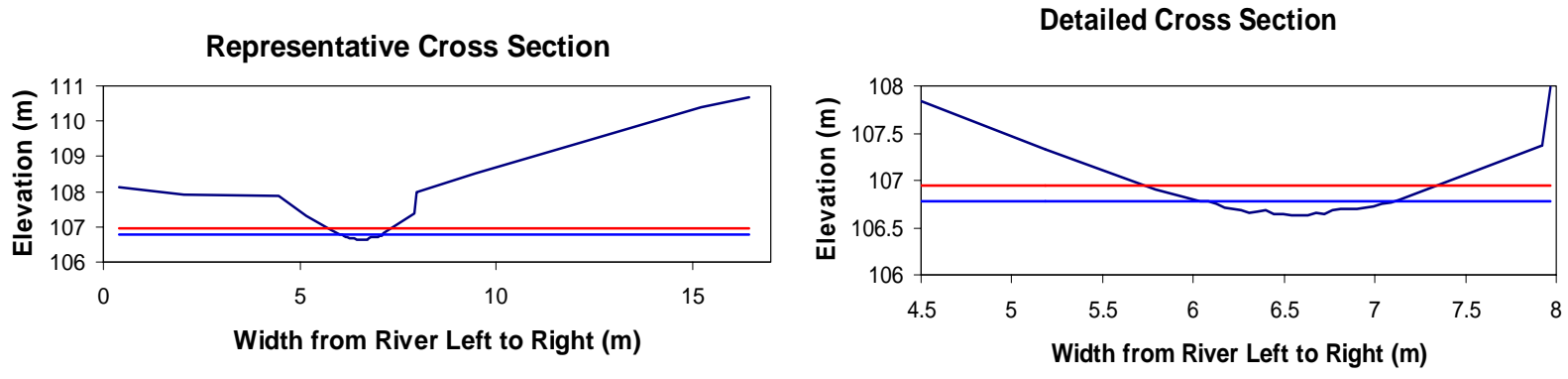


\section{Sediment Characteristics}

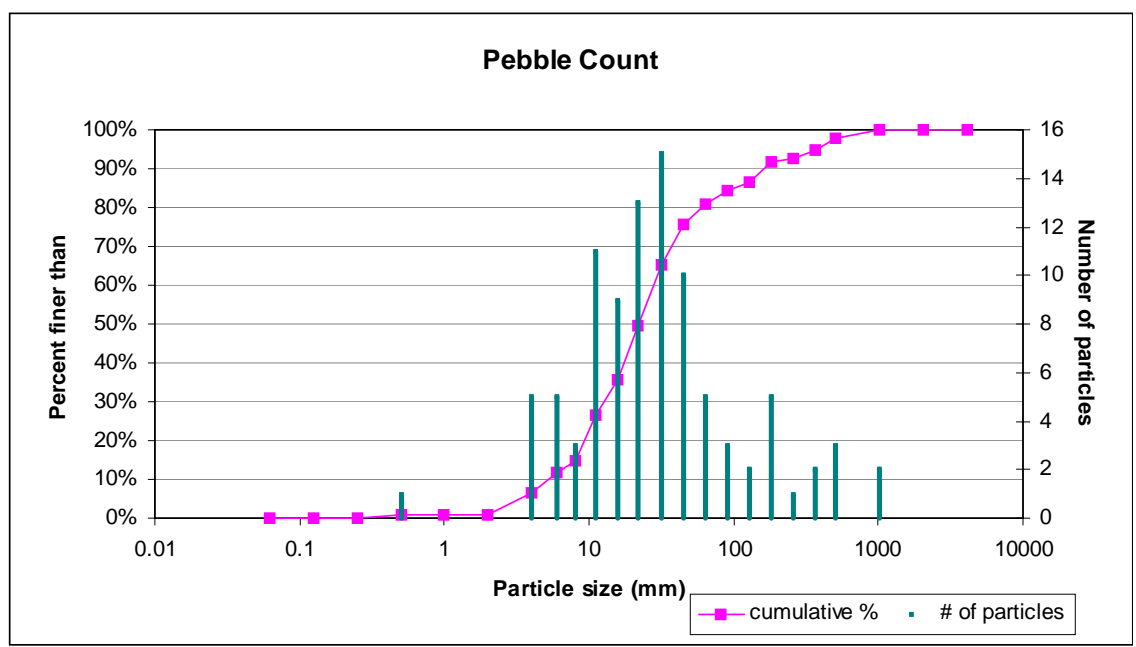

Size Percent Less than (mm): Based on sediment particles only

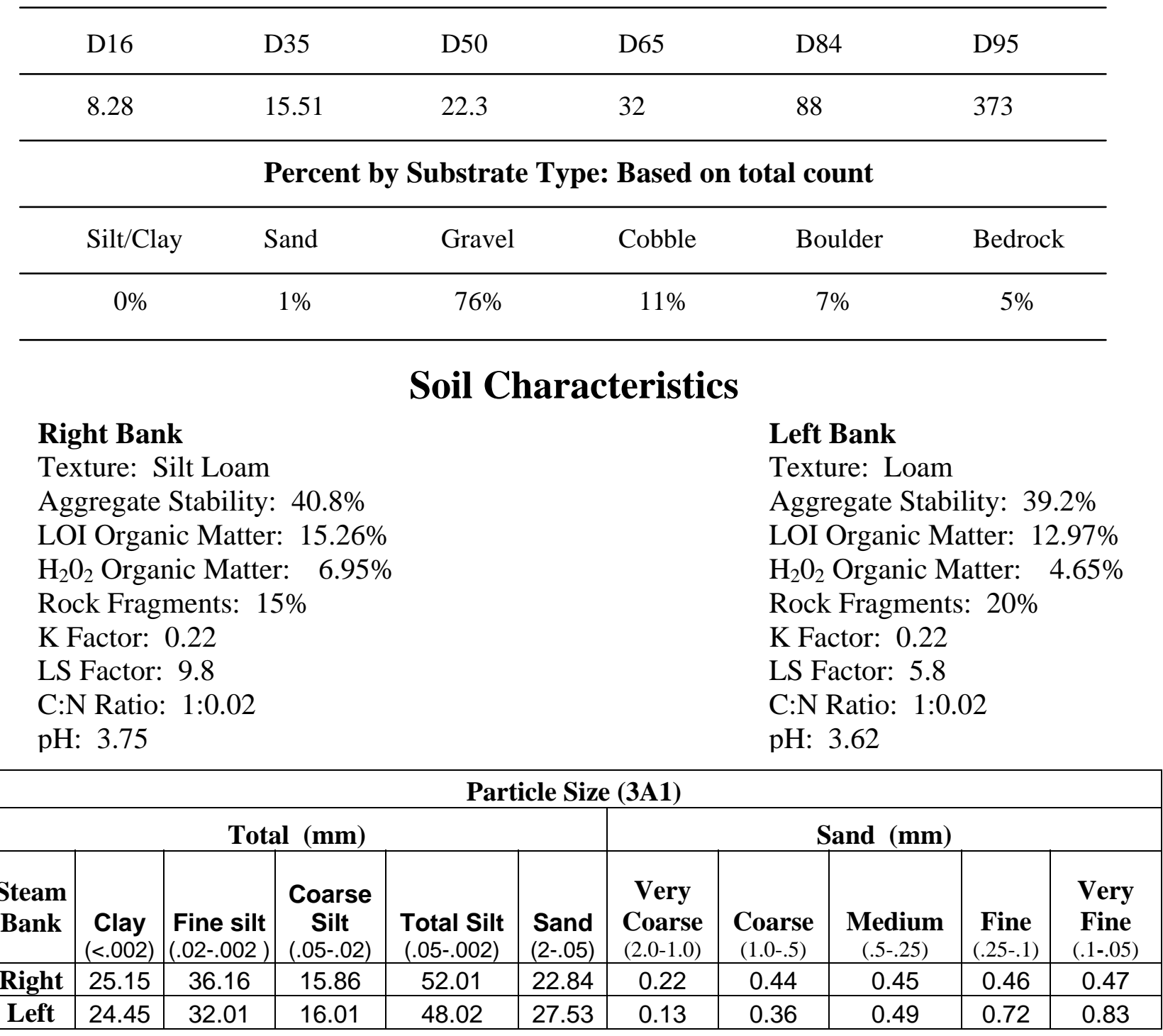




\section{SPHAGNUM RUN: REACH TWO}

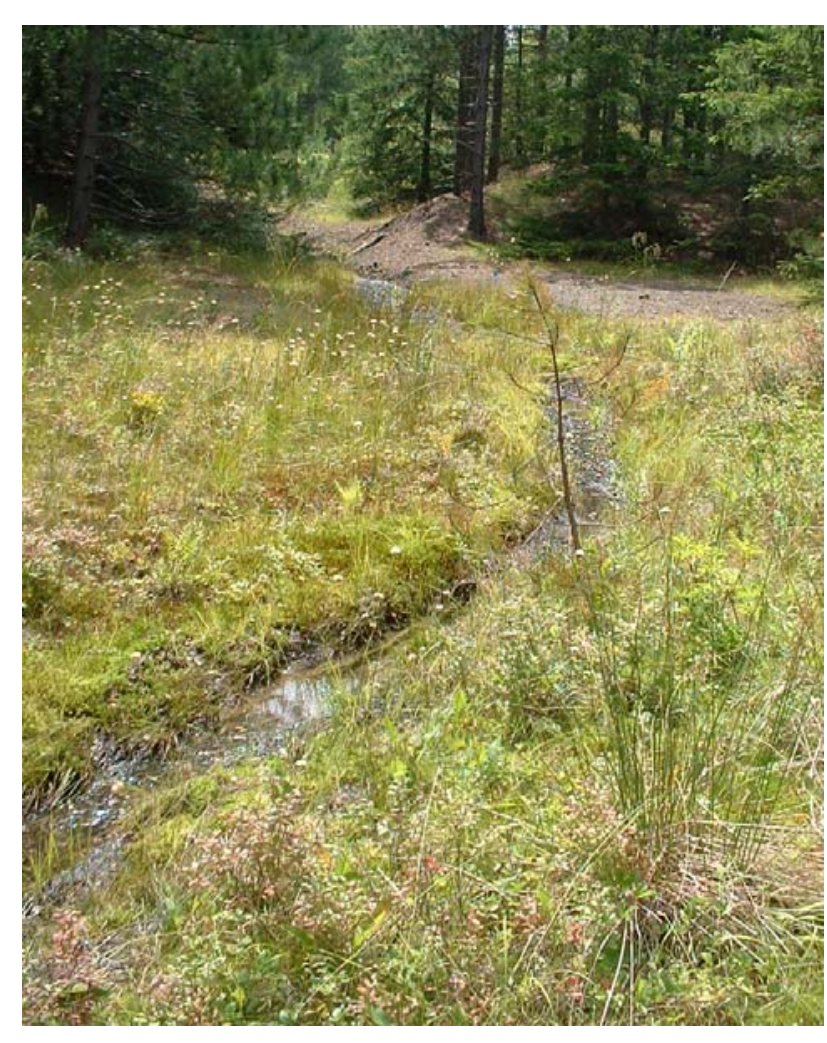

Upstream View

\section{Profile Characteristics}

Bankfull stage width: $2.6 \mathrm{~m}$

Mean bankfull stage depth: $0.1 \mathrm{~m}$

Mean bank height: $2.5 \mathrm{~m}$

Bank slope angle: $2^{\circ}$

Pool to riffle ratio: $1: 2.1$

Channel gradient: $4.65 \%$

\section{Morphological Relationships}

Width to depth ratio: 28.8

Entrenchment: 2.3

Sinuosity: 1.08

Bank height/bankfull stage height: 16

Rooting depth/bank height: 0.19

BEHI rating: 24.6 (Moderate)

\section{Hydraulic Characteristics}

Bankfull discharge (3yr): 86.33 l/s

Bankfull discharge (1.5yr): $54.77 \mathrm{l} / \mathrm{s}$

Stream power (3yr): $0.36 \mathrm{~kg}^{3} / \mathrm{m} / \mathrm{s}$

Stream power (1.5yr): $0.23 \mathrm{~kg}^{3} / \mathrm{m} / \mathrm{s}$

Vegetation Characteristics: Vegetation covered about 78\% of the area surrounding the stream. Sphagnum moss was the dominant species, while sedges, cottonweed, grasses, blueberries, and new york fern were present at lesser degrees. Vegetation was characteristic of a wetland.

Channel Description: Slightly entrenched with a moderate to steep gradient. Dominant channel materials were gravel with fewer amounts of cobble. Streambanks consisted of silty clay loam and silt loam textures.

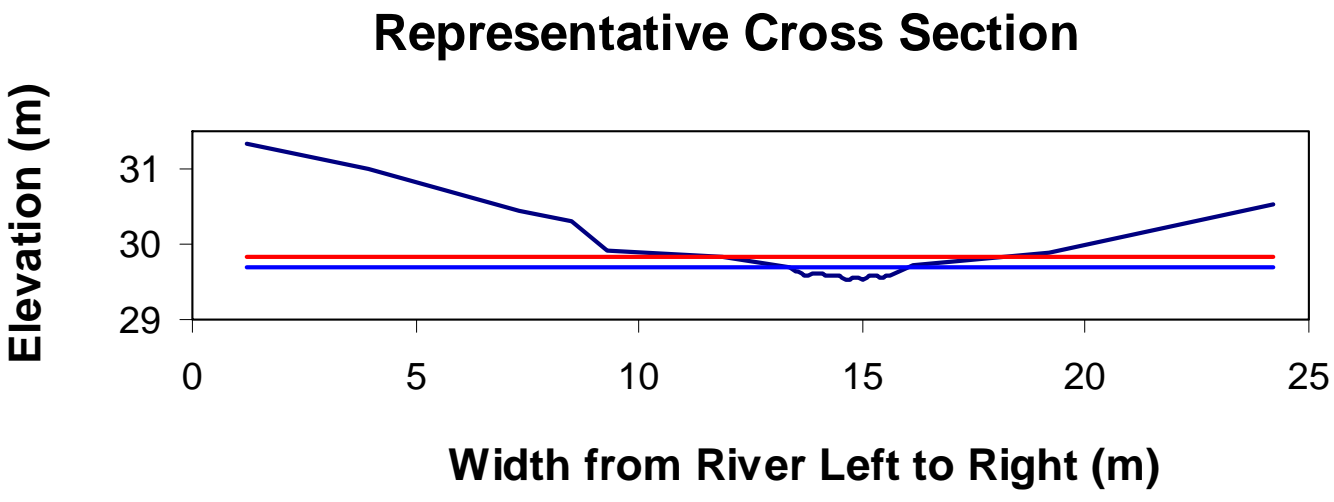




\section{Sediment Characteristics}

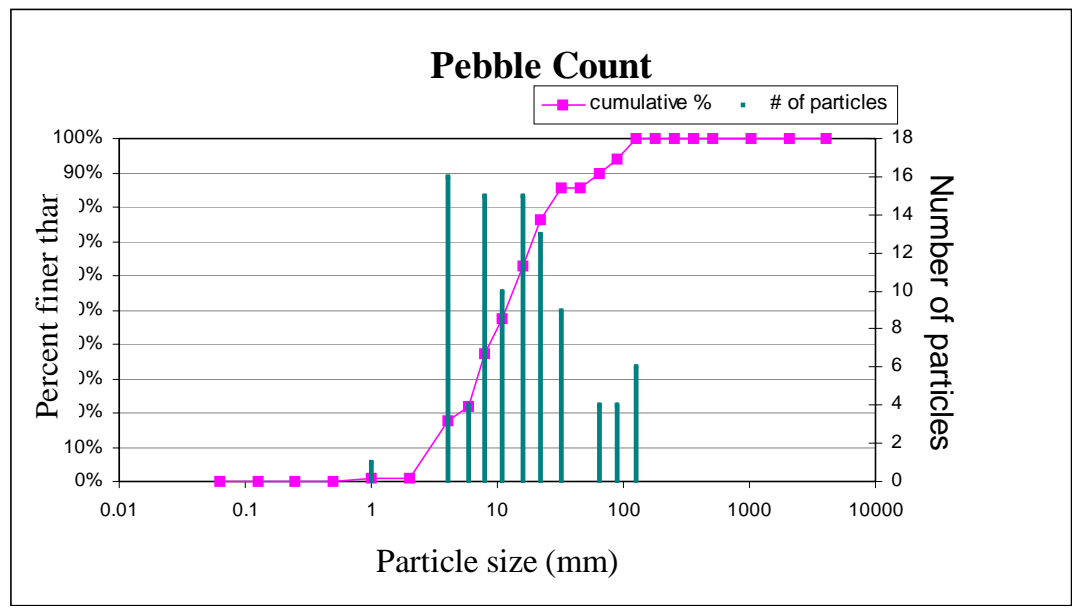

Size Percent Less than (mm): Based on sediment particles only

\begin{tabular}{cccccc}
\hline D16 & D35 & D50 & D65 & D84 & D95 \\
\hline 3.75 & 7.69 & 11.7 & 17 & 30 & 96 \\
\hline & Percent by & Substrate Type: Based on total count & \\
\hline Silt/Clay & Sand & Gravel & Cobble & Boulder & Bedrock \\
\hline $0 \%$ & $1 \%$ & $86 \%$ & $10 \%$ & $0 \%$ & $3 \%$ \\
\hline
\end{tabular}

\section{$\underline{\text { Soil Characteristics }}$}

\section{Right Bank}

Texture: Silty Clay Loam

Aggregate Stability: $14.5 \%$

LOI Organic Matter: $7.1 \%$

$\mathrm{H}_{2} \mathrm{O}_{2}$ Organic Matter: $\quad 4.5 \%$

Rock Fragments: 30\%

K Factor: 0.21

LS Factor: 0.09

C:N Ratio: 1:0.03

pH: 4.17
Left Bank

Texture: Silt Loam

Aggregate Stability: $36.6 \%$

LOI Organic Matter: $18.5 \%$

$\mathrm{H}_{2} \mathrm{O}_{2}$ Organic Matter: 9.4\%

Rock Fragments: 25\%

K Factor: 0.24

LS Factor: 0.09

C:N Ratio: 1:0.02

pH: 4.11

\begin{tabular}{|c|c|c|c|c|c|c|c|c|c|c|}
\hline \multicolumn{11}{|c|}{ Particle Size (3A1) } \\
\hline \multicolumn{6}{|c|}{ Total (mm) } & \multicolumn{5}{|c|}{ Sand (mm) } \\
\hline $\begin{array}{c}\text { Steam } \\
\text { Bank }\end{array}$ & $\begin{array}{c}\text { Clay } \\
(<.002)\end{array}$ & $\begin{array}{l}\text { Fine silt } \\
(.02-.002) \\
\end{array}$ & $\begin{array}{c}\text { Coarse } \\
\text { Silt } \\
(.05-.02)\end{array}$ & \begin{tabular}{|l} 
Total Silt \\
$(.05-.002)$
\end{tabular} & $\begin{array}{l}\text { Sand } \\
(2-.05)\end{array}$ & $\begin{array}{c}\text { Very } \\
\text { Coarse } \\
(2.0-1.0) \\
\end{array}$ & $\begin{array}{c}\text { Coarse } \\
(1.0-.5) \\
\end{array}$ & $\begin{array}{c}\text { Medium } \\
(.5-.25) \\
\end{array}$ & $\begin{array}{c}\text { Fine } \\
(.25-.1) \\
\end{array}$ & $\begin{array}{c}\text { Very } \\
\text { Fine } \\
(.1-.05) \\
\end{array}$ \\
\hline Right & 28.90 & 42.13 & 14.86 & 56.99 & 14.11 & 0.22 & 0.27 & 0.21 & 0.23 & 0.31 \\
\hline Left & 20.30 & 38.35 & 18.19 & 56.54 & 23.16 & 0.31 & 0.35 & 0.32 & 0.44 & 0.62 \\
\hline
\end{tabular}




\section{SPHAGNUM RUN: REACH THREE}

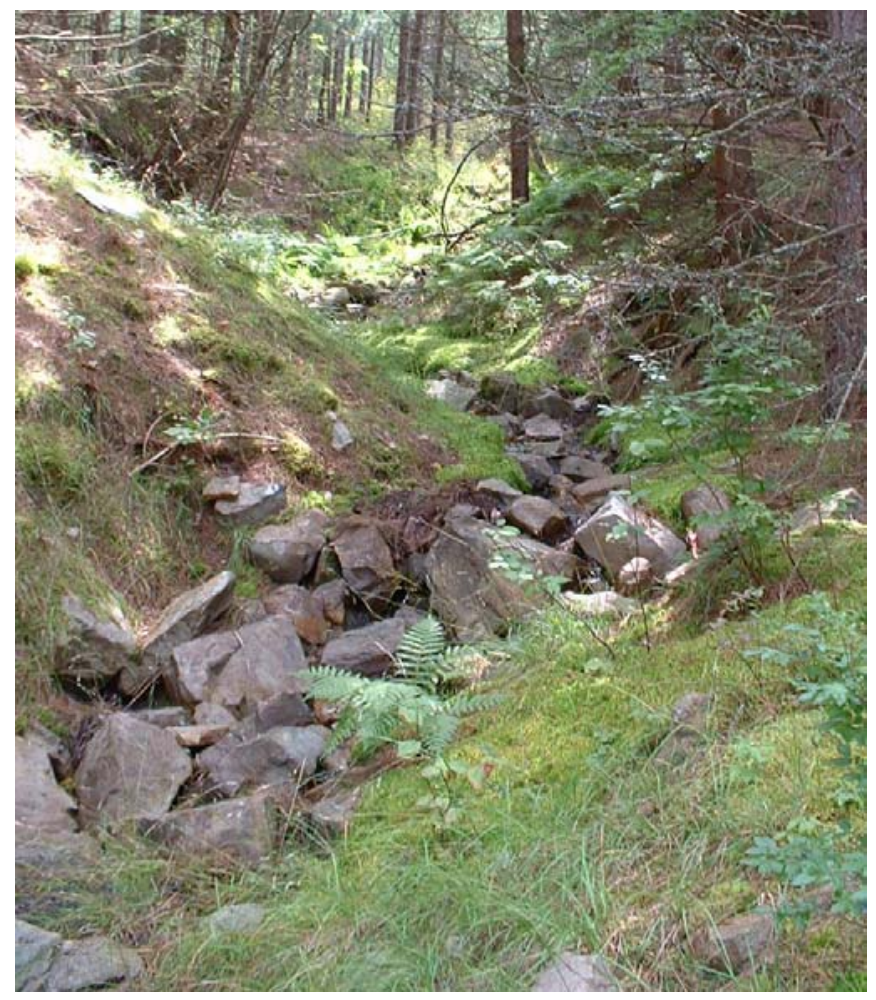

Upstream View

\section{Profile Characteristics}

Bankfull stage width: $2.1 \mathrm{~m}$

Mean bankfull stage depth: $0.09 \mathrm{~m}$

Mean bank height: $9 \mathrm{~m}$

Bank slope angle: $2^{\circ}$

Pool to riffle ratio: $1.3: 1$

Channel gradient: $12.72 \%$

\section{Morphological Relationships}

Width to depth ratio: 20.9

Entrenchment: 1.8

Sinuosity: 1.17

Bank height/bankfull stage height: 12

Rooting depth/bank height: 0.06

BEHI rating: 32.9 (High)

\section{Hydraulic Characteristics}

Bankfull discharge (3yr): $95.56 \mathrm{l} / \mathrm{s}$ Bankfull discharge (1.5yr): $60.58 \mathrm{l} / \mathrm{s}$ Stream power (3yr): $2.90 \mathrm{~kg}^{3} / \mathrm{m} / \mathrm{s}$ Stream power (1.5yr): $1.84 \mathrm{~kg}^{3} / \mathrm{m} / \mathrm{s}$

Vegetation Characteristics: Vegetation covered about 20\% of the channel banks. Red pine, autumn olive, grasses, and new york ferns dominated the banks. Sphagnum moss occurred at a moderate frequency at the base of the banks.

Channel Description: Moderately entrenched channel with a very steep slope. Dominant channel materials were gravel and cobble, while boulder and bedrock occurred less frequently. Channel banks consisting of silt loam textures. Step pool bed features were present in this channel

\section{Representative Cross Section}

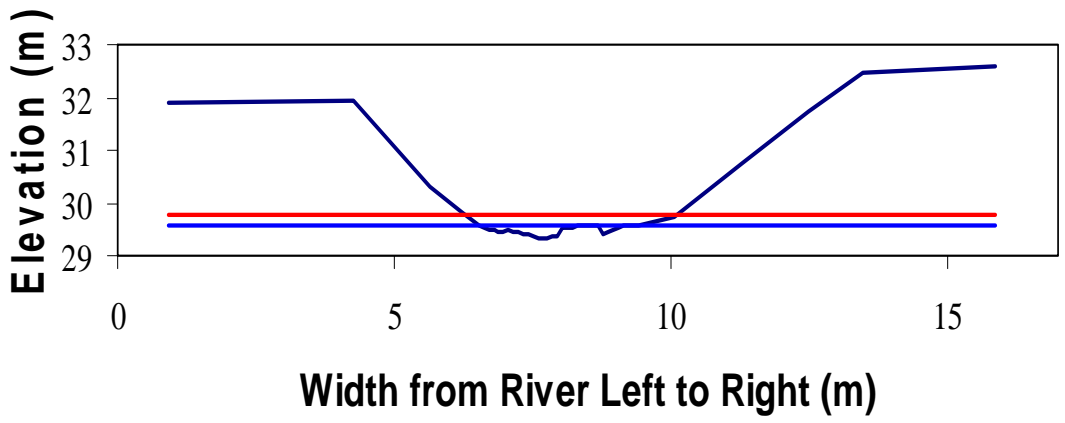




\section{Sediment Characteristics}

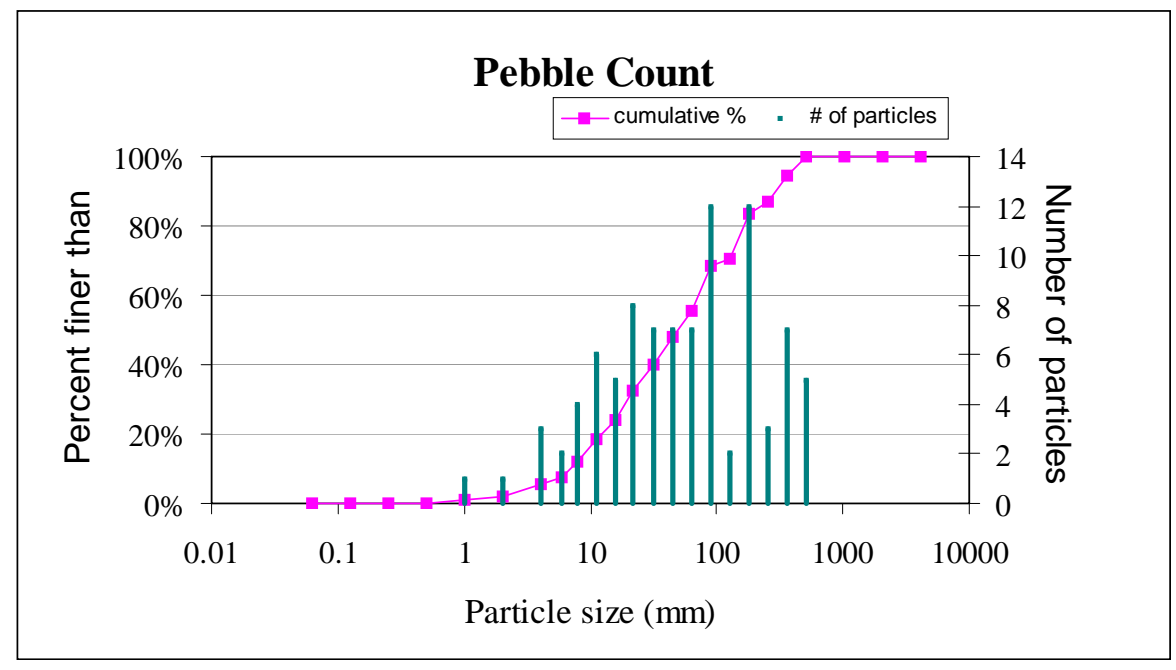

Size Percent Less than (mm): Based on sediment particles only

\begin{tabular}{cccccc} 
D16 & D35 & D50 & D65 & D84 & D95 \\
\hline 9.75 & 24.75 & 49.8 & 82 & 186 & 372 \\
\hline Silt/Clay & Percent by Substrate Type: Based on total count & \\
\hline $0 \%$ & $2 \%$ & Gravel & Cobble & Boulder & Bedrock \\
\hline & $49 \%$ & $29 \%$ & $12 \%$ & $8 \%$ \\
\hline
\end{tabular}

\section{$\underline{\text { Soil Characteristics }}$}

Right Bank

Texture: Silt Loam

Aggregate Stability: $43.2 \%$

LOI Organic Matter: $33.85 \%$

$\mathrm{H}_{2} \mathrm{O}_{2}$ Organic Matter: $16.1 \%$

Rock Fragments: 25\%

K Factor: 0.25

LS Factor: 7.3

C:N Ratio: 1:0.02

pH: 3.87

\section{Left Bank}

Texture: Silt Loam

Aggregate Stability: 49.4\%

LOI Organic Matter: 21.03\%

$\mathrm{H}_{2} \mathrm{O}_{2}$ Organic Matter: $12.2 \%$

Rock Fragments: 30\%

K Factor: 0.23

LS Factor: 6.6

C:N Ratio: 1:0.02

pH: 3.47

\begin{tabular}{|c|c|c|c|c|c|c|c|c|c|c|}
\hline \multicolumn{11}{|c|}{ Particle Size (3A1) } \\
\hline \multicolumn{6}{|c|}{ Total (mm) } & \multicolumn{5}{|c|}{ Sand (mm) } \\
\hline $\begin{array}{c}\text { Steam } \\
\text { Bank }\end{array}$ & $\begin{array}{c}\text { Clay } \\
(<.002)\end{array}$ & $\begin{array}{l}\text { Fine silt } \\
(.02-.002)\end{array}$ & $\begin{array}{c}\text { Coarse } \\
\text { Silt } \\
(.05-.02)\end{array}$ & $\begin{array}{l}\text { Total Silt } \\
(.05-.002)\end{array}$ & $\begin{array}{l}\text { Sand } \\
(2-.05)\end{array}$ & $\begin{array}{c}\text { Very } \\
\text { Coarse } \\
(2.0-1.0)\end{array}$ & $\begin{array}{c}\text { Coarse } \\
(1.0-.5)\end{array}$ & $\begin{array}{c}\text { Medium } \\
(.5-.25)\end{array}$ & $\begin{array}{c}\text { Fine } \\
(.25-.1)\end{array}$ & $\begin{array}{c}\text { Very } \\
\text { Fine } \\
(.1-.05)\end{array}$ \\
\hline Right & 16.06 & 32.94 & 21.28 & 54.21 & 29.73 & 0.13 & 0.20 & 0.29 & 0.56 & 0.89 \\
\hline Left & 22.02 & 39.35 & 18.20 & 57.55 & 20.43 & 0.11 & 0.22 & 0.27 & 0.42 & 0.59 \\
\hline
\end{tabular}




\section{SPHAGNUM RUN: REACH FOUR}

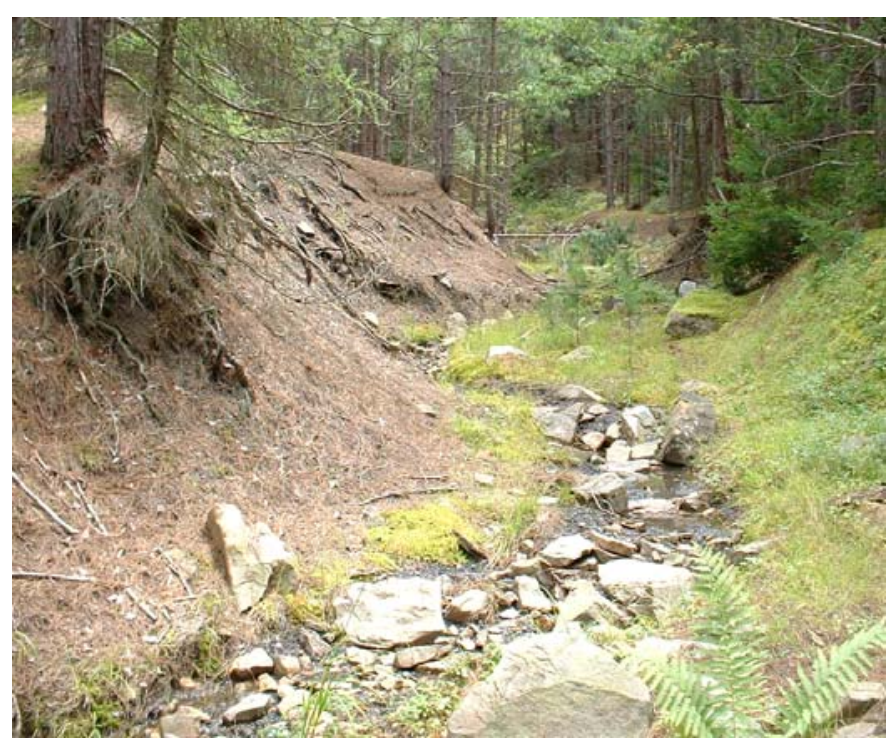

Upstream View

\section{Profile Characteristics}

Bankfull stage width: $2.2 \mathrm{~m}$

Mean bankfull stage depth: $0.1 \mathrm{~m}$

Mean bank height: $1.8 \mathrm{~m}$

Bank slope angle: $47.5^{\circ}$

Pool to riffle ratio: $1: 1.6$

Channel gradient: $5.39 \%$

\section{Morphological Relationships}

Width to depth ratio: 15.4

Entrenchment: 1.9

Sinuosity: 1.23

Bank height/bankfull stage height: 2.9

Rooting depth/bank height: 0.06

BEHI rating: 37.1 (High)

\section{Hydraulic Characteristics}

Bankfull discharge (3yr): 102.31 l/s

Bankfull discharge (1.5yr): $64.84 \mathrm{l} / \mathrm{s}$

Stream power (3yr): $0.97 \mathrm{~kg}^{3} / \mathrm{m} / \mathrm{s}$

Stream power (1.5yr): $0.61 \mathrm{~kg}^{3} / \mathrm{m} / \mathrm{s}$

Vegetation Characteristics: Vegetation covered about $18 \%$ of the channel banks. The right bank was sparsely vegetated with red spruce and generally had no groundcover. Red pine, red spruce, grasses, and fewer ferns were prominent on the left bank. Sphagnum moss occurred in sparse patches along the channel.

Channel Description: Moderately entrenched with a steep gradient. Dominant channel materials were gravel, while cobble occurs relatively frequently throughout the channel. Channel banks consisted of clay loam and silt loam textures.

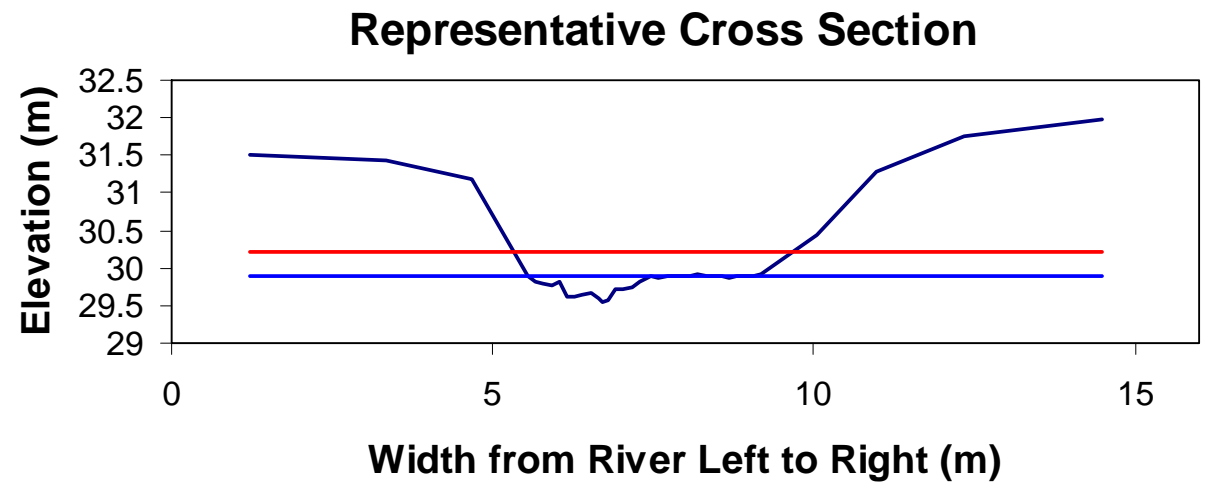




\section{Sediment Characteristics}

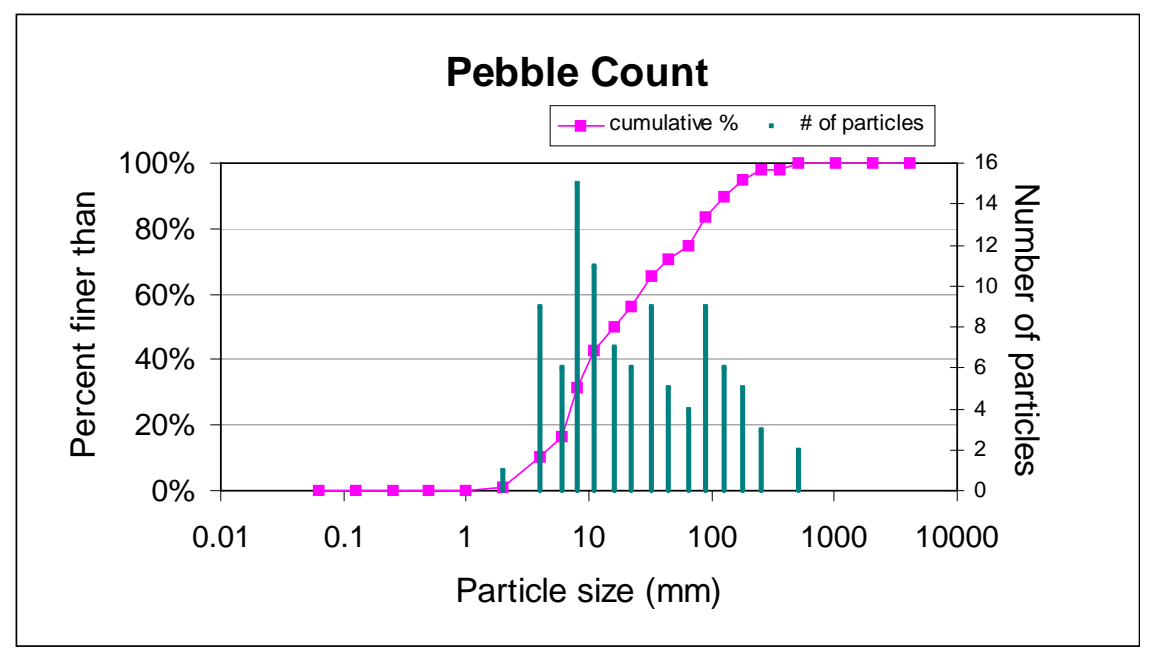

Size Percent Less than (mm): Based on sediment particles only

\begin{tabular}{cccccc}
\hline D16 & D35 & D50 & D65 & D84 & D95 \\
\hline 5.87 & 8.8 & 16 & 32 & 92 & 182 \\
\hline Silt/Clay & Sand & Gravel & Cobble & Boulder & Bedrock \\
\hline $0 \%$ & $1 \%$ & $72 \%$ & $23 \%$ & $2 \%$ & $2 \%$ \\
\hline
\end{tabular}

\section{$\underline{\text { Soil Characteristics }}$}

\section{Right Bank}

Texture: Clay Loam

Aggregate Stability: $41.2 \%$

LOI Organic Matter: 26.15\%

$\mathrm{H}_{2} \mathrm{O}_{2}$ Organic Matter: $12.15 \%$

Rock Fragments: 7\%

K Factor: 0.21

LS Factor: 4.0

C:N Ratio: 1:0.02

$\mathrm{pH}: 3.47$

\section{Left Bank}

Texture: Silt Loam

Aggregate Stability: $7.8 \%$

LOI Organic Matter: 13.9\%

$\mathrm{H}_{2} \mathrm{O}_{2}$ Organic Matter: $7.25 \%$

Rock Fragments: 25\%

K Factor: 0.22

LS Factor: 4.7

C:N Ratio: 1:0.02

pH: 3.60

\begin{tabular}{|c|c|c|c|c|c|c|c|c|c|c|}
\hline \multicolumn{11}{|c|}{ Particle Size (3A1) } \\
\hline \multicolumn{6}{|c|}{ Total (mm) } & \multicolumn{5}{|c|}{ Sand (mm) } \\
\hline $\begin{array}{l}\text { Steam } \\
\text { Bank }\end{array}$ & $\begin{array}{c}\text { Clay } \\
(<.002)\end{array}$ & $\begin{array}{l}\text { Fine silt } \\
(.02-.002)\end{array}$ & $\begin{array}{c}\text { Coarse } \\
\text { Silt } \\
(.05-.02)\end{array}$ & $\begin{array}{l}\text { Total Silt } \\
(.05-.002)\end{array}$ & $\begin{array}{l}\text { Sand } \\
(2-.05)\end{array}$ & $\begin{array}{l}\text { Very } \\
\text { Coarse } \\
(2.0-1.0)\end{array}$ & $\begin{array}{c}\text { Coarse } \\
(1.0-.5)\end{array}$ & $\underset{(.5-.25)}{\text { Medium }}$ & $\begin{array}{c}\text { Fine } \\
(.25-.1)\end{array}$ & $\begin{array}{c}\text { Very } \\
\text { Fine } \\
(.1-.05)\end{array}$ \\
\hline Right & 27.39 & 32.21 & 13.92 & 46.13 & 26.48 & 0.07 & 0.21 & 0.39 & 0.72 & 0.76 \\
\hline Left & 25.62 & 35.78 & 14.91 & 50.68 & 23.69 & 0.20 & 0.31 & 0.38 & 0.56 & 0.60 \\
\hline
\end{tabular}




\section{SPHAGNUM RUN: REACH FIVE}

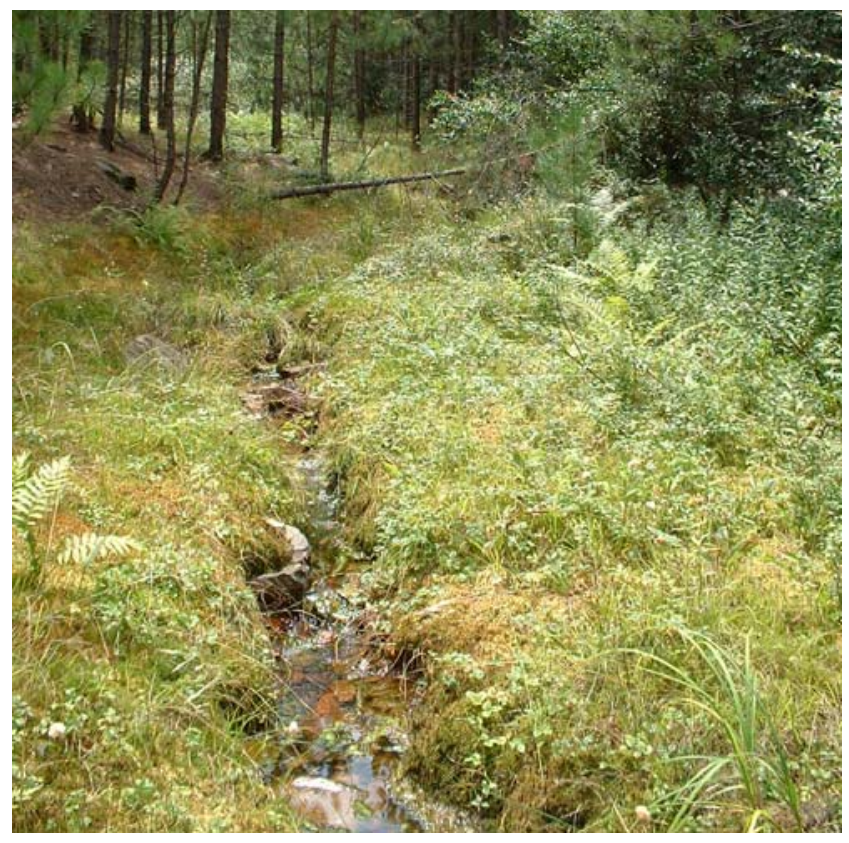

Upstream View

\section{Profile Characteristics}

Bankfull stage width: $3.3 \mathrm{~m}$

Mean bankfull stage depth: $0.3 \mathrm{~m}$

Mean bank height: $0.3 \mathrm{~m}$

Bank slope angle: $2^{\circ}$

Pool to riffle ratio: $1.1: 1$

Channel gradient: $2.47 \%$

\section{Morphological Relationships}

Width to depth ratio: 137.8

Entrenchment: 2.4

Sinuosity: 0.80

Bank height/bankfull stage height: 7.8

Rooting depth/bank height: 0.6

BEHI rating: 17.7 (Low)

\section{Hydraulic Characteristics}

Bankfull discharge (3yr): 102.31 l/s

Bankfull discharge (1.5yr): $64.84 \mathrm{l} / \mathrm{s}$

Stream power (3yr): $0.97 \mathrm{~kg}^{3} / \mathrm{m} / \mathrm{s}$

Stream power (1.5yr): $0.61 \mathrm{~kg}^{3} / \mathrm{m} / \mathrm{s}$

Vegetation Characteristics: Dominant vegetation included sphagnum moss, sedges, cotton weed, grasses, with fewer autumn olive and red pine. Vegetation was characteristic of a wetland.

Channel Description: Slightly entrenched with a gentle gradient. Dominant channel materials were gravel, while cobble occurs at a much lesser degree. Channel banks consisting of silty clay loam textures.

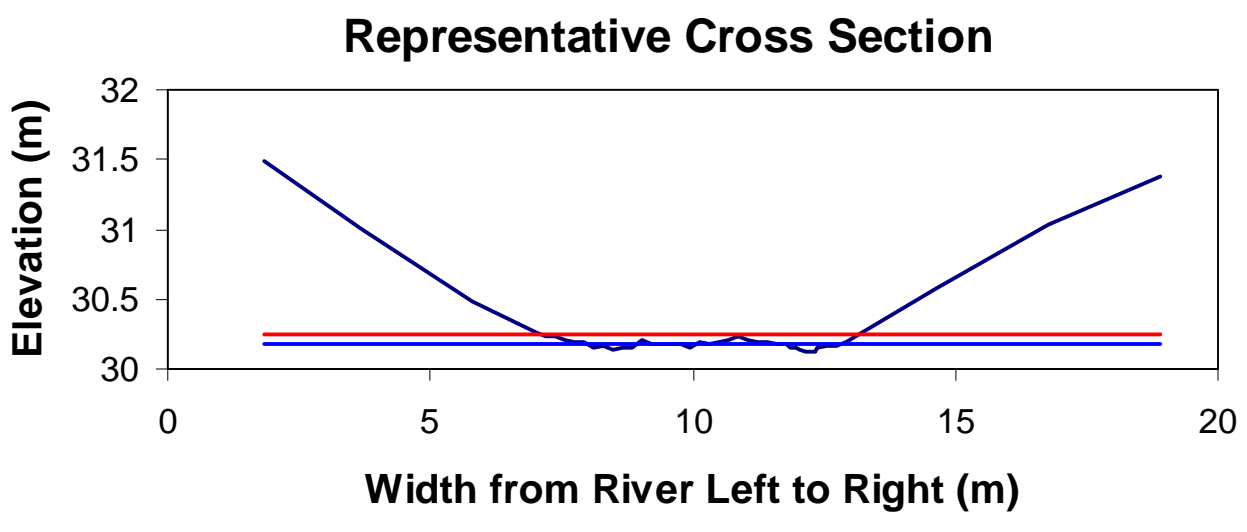




\section{Sediment Characteristics}

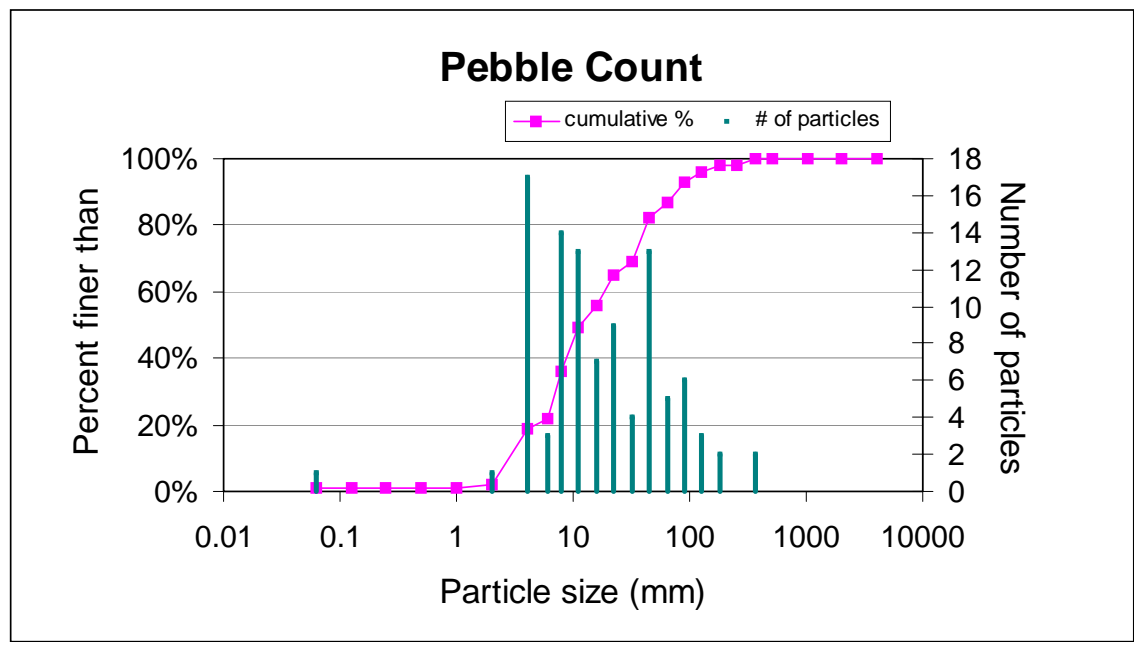

Size Percent Less than (mm): Based on sediment particles only

\begin{tabular}{cccccc}
\hline D16 & D35 & D50 & D65 & D84 & D95 \\
\hline 3.5 & 7.8 & 11.6 & 22 & 52 & 114 \\
\hline & Percent by Substrate Type: Based on total count & \\
\hline Silt/Clay & Sand & Gravel & Cobble & Boulder & Bedrock \\
\hline $1 \%$ & $1 \%$ & $85 \%$ & $11 \%$ & $2 \%$ & $0 \%$ \\
\hline
\end{tabular}

\section{$\underline{\text { Soil Characteristics }}$}

\section{Right Bank}

Texture: Silty Clay Loam

Aggregate Stability: $41.2 \%$

LOI Organic Matter: 26.50\%

$\mathrm{H}_{2} \mathrm{O}_{2}$ Organic Matter: $12.15 \%$

Rock Fragments: 20\%

K Factor: 0.24

LS Factor: 0.2

C:N Ratio: 1:0.02

pH: 3.47

\section{Left Bank}

Texture: Silty Clay Loam

Aggregate Stability: $7.8 \%$

LOI Organic Matter: $13.90 \%$

$\mathrm{H}_{2} \mathrm{O}_{2}$ Organic Matter: $7.25 \%$

Rock Fragments: 10\%

K Factor: 0.20

LS Factor: 0.2

C:N Ratio: 1:0.05

$\mathrm{pH}: 3.60$

\begin{tabular}{|c|c|c|c|c|c|c|c|c|c|c|}
\hline \multicolumn{11}{|c|}{ Particle Size (3A1) } \\
\hline \multicolumn{6}{|c|}{ Total (mm) } & \multicolumn{5}{|c|}{ Sand (mm) } \\
\hline $\begin{array}{l}\text { Steam } \\
\text { Bank }\end{array}$ & $\begin{array}{c}\text { Clay } \\
(<.002)\end{array}$ & $\begin{array}{l}\text { Fine silt } \\
(.02-.002)\end{array}$ & $\begin{array}{c}\text { Coarse } \\
\text { Silt } \\
(.05-.02)\end{array}$ & $\begin{array}{c}\text { Total Silt } \\
(.05-.002)\end{array}$ & $\begin{array}{l}\text { Sand } \\
(2-.05)\end{array}$ & $\begin{array}{c}\text { Very } \\
\text { Coarse } \\
(2.0-1.0)\end{array}$ & $\begin{array}{c}\text { Coarse } \\
(1.0-.5)\end{array}$ & $\underset{(.5-.25)}{\text { Medium }}$ & $\begin{array}{c}\text { Fine } \\
(.25-.1)\end{array}$ & $\begin{array}{c}\text { Very } \\
\text { Fine } \\
(.1-.05)\end{array}$ \\
\hline Right & 32.08 & 38.85 & 12.73 & 51.58 & 16.34 & 0.13 & 0.21 & 0.23 & 0.37 & 0.46 \\
\hline Left & 31.56 & 37.33 & 11.95 & 49.27 & 19.17 & 0.10 & 0.14 & 0.25 & 0.50 & 0.74 \\
\hline
\end{tabular}

